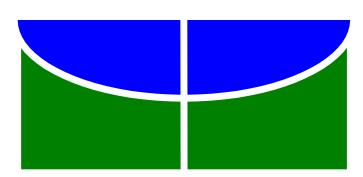

Universidade de Brasília (UnB)

Faculdade de Ciência da Informação (FCI)

Programa de Pós-Graduação em Ciência da Informação (PPGCInf)

JOSE ROBERTO PIMENTA FERRETTI DA COSTA

\title{
VARIÁVEIS DO COMPARTILHAMENTO DE CONHECIMENTO \\ TÁCITO NOS JUIZADOS ESPECIAIS FEDERAIS DO BRASIL: IDENTIFICAÇÃO E MENSURAÇÃO
}

\author{
Brasília - DF \\ 2016
}




\section{VARIÁVEIS DO COMPARTILHAMENTO DE CONHECIMENTO TÁCITO NOS JUIZADOS ESPECIAIS FEDERAIS DO BRASIL: IDENTIFICAÇÃO E MENSURAÇÃO}

Tese apresentada ao Programa de Pós-graduação em Ciência da Informação da Universidade de Brasília como requisito parcial para obtenção do título de Doutor em Ciência da Informação.

Orientadora: Profa. Dra. Lillian Maria Araújo de Rezende Alvares.

Brasília - DF

2016 
Universidade de Brasília (UnB)

Faculdade de Ciência da Informação (FCI)

Programa de Pós-Graduação em Ciência da Informação (PPGCInf)

Doutorado em Ciência da Informação

F387p

Ferretti, José

Variáveis do compartilhamento de conhecimento tácito nos Juizados Especiais Federais do Brasil [manuscrito] / por José Ferretti. 2016.

200 f. : il.

Tese (Doutorado) - Universidade de Brasília, Faculdade de Ciência da Informação (FCI), Brasília, 2016.

Orientação: Profa. Dra. Lillian Maria A. R. Alvares, Faculdade de Ciência da Informação (FCI).

Tese elaborada sob afastamento concedido nos termos do Processo 2.054/2012 - TRF1 e publicado em Boletim de Serviço No 60, de 03 de abril de 2012.

I. Título. 


\section{FOLHA DE APROVAÇÃO}

Título: "VARIÁVEIS DO COMPARTILHAMENTO DE CONHECIMENTO TÁCITO NOS JUIZADOS ESPECIAIS FEDERAIS DO BRASIL: IDENTIFICAÇÃO E MENSURAÇÃO".

Autor (a): José Roberto Pimenta Ferretti da Costa

Área de concentração: Gestão da Informação

Linha de pesquisa: Organização da Informação

Tese submetida à Comissão Examinadora designada pelo Colegiado do Programa de Pósgraduação em Ciência da Informação da Faculdade de Ciência da Informação da Universidade de Brasília como requisito parcial para obtenção do título de Doutor em Ciência da Informação.

Tese aprovada em: 29 de março de 2016.

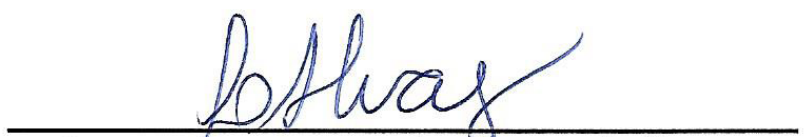

Profa. Dra. Lillian Maria Araújo de Rezende Álvares Presidente (UnB/PPGCINF)

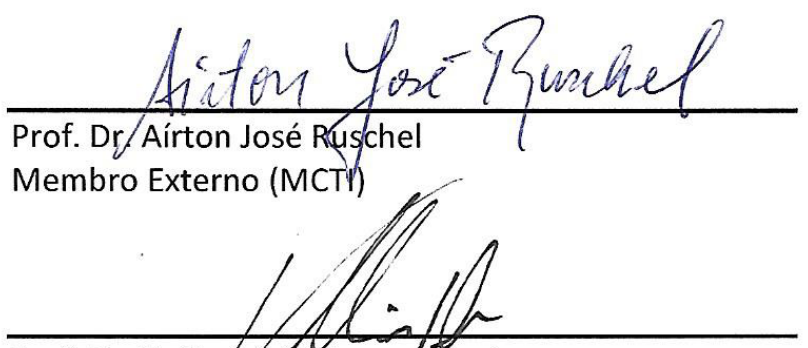

Prof. Dr. Vallisndey de Souza Óliveira Membro Extegno (UnB/FD)

Profa. Drạ. Elmira Luzia Melo-Soares Simeão Membro Intermo (UnB/PPCCINF)

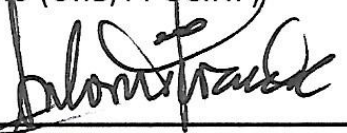

Prof. Dr. (Antônío Lisboa Carvalho de Miranda Membro Interno (UnB/FCl)

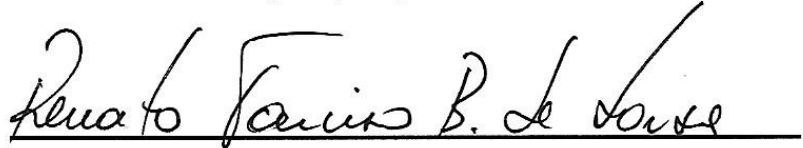

Prof. Dr. Renato Tarciso Barbosa de Sousa

Suplente (UnB/PPGCINF) 


\section{DEDICATÓRIA}

A Deus que me apontou a vitória antes mesmo do início da batalha, encorajando-me em todos os momentos a prosseguir e vencer, assim como um pai procede com seu filho.

Obrigado Senhor pela graça derramada, pela confirmação da obra de minhas mãos; sim, o Senhor confirmou a obra de minhas mãos (Salmos, 90.17).

À minha família, Neiva Mendonça, esposa que infatigavelmente me apoiou e motivou nessa luta e os filhos Daniel, Camila e José que souberam perdoarme pelos momentos de ausência física e presença volátil.

Aos meus pais, Oswaldo Ferretti da Costa, homem justo, que partiu durante a trajetória, orgulhoso pelo filho permanecer em crescimento e Adahyr Pimenta da Costa, símbolo de humildade e amor. 


\section{AGRADECIMENTOS}

Aos juízes e juízas participantes da amostra que atenciosamente interromperam suas atividades para contribuir com seus dados pessoais e informações e conhecimentos acerca do fenômeno do compartilhamento de seus conhecimentos tácitos.

Aos Presidentes e Coordenadores dos Juizados Especiais Federais dos cinco Tribunais Regionais Federais que autorizaram a minha pesquisa.

Ao Desembargador Olindo Menezes, Presidente do Tribunal Regional Federal da $1^{\text {a }}$ Região, que com visão autorizou o meu afastamento.

À Desembargadora Neuza Alves que carinhosamente aceitou minhas investidas no Projeto MELHORAÇÃO (2013/2014), permitindo-me ver refletida a validade da pesquisa em questão.

Ao Diretor-Geral do Tribunal Regional Federal da $1^{\text {a }}$ Região, Felipe dos Santos Jacinto, que com confiança permitiu minha breve ausência.

À Diretora do Centro de Estudos e Apoio à Gestão, hoje, Secretaria de Gestão Estratégica e Inovação do Tribunal Regional Federal da $1^{\text {a }}$ Região, Wânia Marítiça Vieira, que com audácia abriu as portas da fronteira organizacional aos campos acadêmicos.

As amigas e secretárias do Programa de pós-Graduação em Ciência da Informação (PPGCINF), Jucilene Moreira, Martha Araújo e Vívian Miatelo pelo sempre disposto e cordial atendimento, fundamental para nossa eficaz trajetória.

Aos Professores da UnB, Carlos Alberto Tomaz (Neurociências), Hartmut Gunther e Jairo Borges (Psicologia) e Profa. Catarina Odelius (Administração) que sinalizaram o caminho a ser percorrido.

Aos professores Suzana Müeller, Marcílio de Brito, Lillian Alvares, Murilo Cunha, Rogério de Araújo, Renato Sousa que apresentaram a um "estranho", egresso da Gestão Pública, os fundamentos e os meandros da Ciência da Informação.

Ao Dr. Eduardo Moresi (Centro de Gestão e Estudos Estratégicos - CGEE) e Dr. Gutemberg Sousa (Comissão Técnica Nacional de Biossegurança - CTNBio) que destinaram parte de seu tempo na análise de versões preliminares do trabalho.

Aos integrantes do Grupo de Pesquisa "Gestão e Inovação em Organizações da Justiça - GIJ" (PPGA - UnB), na pessoa do Dr. Tomas Guimarães, que emprestaram suas expertise para retificar e engrandecer o estudo.

Ao Dr. Philip Langbroek, Director of the Montaigne Centre for Judicial Administration and Conflict Resolution. Professor of Justice Administration and Judicial organisation, Utrecht School of Law, Utrecht University, Netherlands, que sofisticadamente questionou-me sobre alguns conceitos e caminhos e proporcionou-me uma reflexão sobre os rumos e a apresentação da pesquisa.

À amiga e pesquisadora de bases nacionais e internacionais, Beth Brant, que pavimentou minha caminhada com obras meticulosamente recolhidas.

À tradutora Debbie Mesquita, que me auxiliou em traduções na língua inglesa. 
À designer gráfico e artista, Amanda Priscilla, que deu vida às imagens e as tornou significativamente mais atraentes.

À Martha Gandra, Mestre em Direito Internacional e servidora do Conselho da Justiça Federal, que me municiou de dados judiciais sobremaneira importantes ao sucesso da tese.

À Formatum Consultoria, nas pessoas dos amigos Leonardo, Luciana e Gabriel que apoiaram a pesquisa com impecável atenção às normas de formatação de trabalhos científicos.

À Odds \& Actions, Consultoria em Estatística, nas pessoas de seus sócios Leonardo Aguirre e Erick Damasceno, que muito contribuíram na compreensão das searas técnicas e na bem utilização das ferramentas estatísticas que robusteceram a metodologia.

À Lakeview Crossfit, nas pessoas dos Professores Rhon Werberich, Paula Emediato e Tiago Cacau que com orientações precisas apoiaram-me na preparação física e mental tão útil e necessária ao empreendimento.

Ao médico Paulo Pecoits e à Nutricionista Tane Hermuche que com maestria tornaram-me organicamente forte para suportar a caminhada.

À amiga Conceição que colaborou intensamente na disposição dos conteúdos e na formatação do trabalho.

À colega do Tribunal Regional Federal da $1^{\text {a }}$ Região, Mestre em Ciência da Informação, amiga e eterna consultora, Márcia Mazo, que me introduziu no mundo dessa Ciência, madrinha, portanto, deste projeto.

Ao Professor de Inglês, tradutor e 'Copensador', Amir Qaddomi, que não mediu esforços em acompanhar-me na complexa arte de bem me comunicar na língua inglesa com refinamentos acadêmicos.

Aos meus irmãos Abel, Paulo, Carlos e Marta Ferretti que sempre me estimularam a concretizar a obra.

Aos irmãos em Cristo, Ronaldo e Joselma Silva, que forneceram um carinhoso apoio material e espiritual, sem o qual seria deveras complicada a execução do projeto.

Aos professores da banca, Dra. Lillian Alvares (Presidente), Dra. Elmira Simeão, Dr. Antonio Miranda, Dr. Renato Sousa, Dr. Vallisney Oliveira e Dr. Aírton José Ruschel que me honraram em apreciar o trabalho, conferindo-lhe um sentido mais certeiro ao alcance dos objetivos propostos.

À minha Orientadora e amiga, Profa. Lillian Alvares, que sempre acreditou na proposta e motivou-me a buscar algo que trouxesse significância à ciência e benefícios ao Poder Judiciário e à sociedade em geral. 


\section{RESUMO}

O objetivo desta pesquisa foi identificar as variáveis que explicam o compartilhamento do conhecimento tácito no âmbito dos Juizados Especiais Federais (JEF), consoante a perspectiva dos juízes. A hipótese central, baseada na literatura e na experiência do autor, assumiu que em torno do juiz encontra-se estabelecida uma rede de compartilhamento (RC), formada pelos seus pares, pelos agentes do sistema de justiça (ASJ) e pelos servidores que compõem a sua equipe, que, segundo dimensões de natureza pessoal, acadêmica, funcional, organizacional, geográfica e social, efetuam o compartilhamento do conhecimento tácito. A literatura conceitua o conhecimento tácito e o compartilhamento, define-os como ativos imateriais, mas valiosos, e apresenta estudos que os associam a um novo paradigma organizacional baseado em conhecimento. Para a identificação das variáveis explicativas do compartilhamento, um método foi desenvolvido e está composto das seguintes etapas e estágios: (1) Identificação do agente central; (2) Explicitação da Rede de Compartilhamento (RC); (3) Mapeamento das possíveis variáveis explicativas, estabelecimento das hipóteses e elaboração do instrumento de coleta de dados e informações (o questionário); 4) Criação de uma unidade de medida capaz de mensurar a propensão ao compartilhamento do conhecimento tácito; (5) Estimação dos impactos das variáveis hipotéticas (VH) sobre do indicador e identificação das variáveis explicativas (VE). Foram colhidos dados e informações de 95 juízes (de uma amostra de 105). Os resultados obtidos foram: (I) a caracterização os sujeitos amostrais, segundo as variáveis hipotéticas (VH) incorporadas pela hipótese; (II) a criação de uma nova unidade de medida de propensão ao compartilhamento de conhecimento tácito (anyi); (III) a formulação de um indicador numérico que mensurasse a propensão ao compartilhamento do conhecimento tácito; (IV) a identificação das variáveis explicativas do fenômeno do compartilhamento (idade, tempo de magistratura, tempo de JEF, Região da Justiça Federal, participação (ou não) em eventos de natureza interativa, participação em redes sociais de caráter técnico, emprego de aparelhos de comunicação privados (smartphones, tablets etc), concordância (ou não) que o compartilhamento é imprescindível aos trabalhos do juiz); e as possibilidades de: (V) verificação do valor e da positividade do impacto das VE sobre o indicador; (VI) estimação da propensão individual de um juiz compartilhar o seu conhecimento tácito; e a partir desse índice, (VII) estabelecimento de graus de compartilhamento para juízes entre $(0,1)$; e (VIII) segmentação dos juízes quanto a faixas de propensão: (0-0,25), grau de compartilhamento baixo; $(0,26-0,50)$, moderadobaixo; (0,51-0,75), moderado-alto; e $(0,76-1,00)$, alto. Como conclusão, verificou-se ser possível: identificar quais variáveis explicam a propensão ao compartilhamento do conhecimento tácito, segundo o método proposto, e auxiliar os JEF a melhor compreender os fluxos de conhecimento tácito associados ao juiz.

Palavras-chave: Compartilhamento de conhecimento. Conhecimento tácito. Indicador. Juizado Especial Federal. 


\begin{abstract}
The purpose of this research was to identify the variables that explain the sharing of tacit knowledge within the Federal Special Courts (JEF), from the perspective of the judges. The central hypothesis, based on the literature and the author's experience, assumed that judges have an established system of network sharing (RC), composed by their peers, by agents of the justice system (ASJ) and civil servants that make up their team, which, according to dimensions of personal, academic, functional, organizational, geographical and social nature, effect the sharing of tacit knowledge. The literature conceptualizes tacit knowledge and sharing it as intangible assets, but valuable, and current studies link them to a new organizational paradigm based on knowledge. In order to identify the variables that explain sharing, a method was developed and was composed of the following steps and stages: (1) identification of the central agent; (2) Explanation of the Sharing Network (RC); (3) Mapping of possible descriptive variables, establishing the assumptions and preparation of the data and information collection instrument (the questionnaire); 4) Creating a measurement unit capable of measuring the propensity for sharing tacit knowledge; (5) Estimation of the impact of the hypothetical variables $(\mathrm{VH})$ on the unit and the identification of the descriptive variables (VE). Data and information from 95 judges were collected (from a sample of 105). The results were: (I) characterizing the sample of the subjects according to the hypothetical variable (VH) incorporated by the hypothesis; (II) the creation of a new unit for measuring tacit knowledge sharing (anyi); (III) the formulation of a numerical indicator that measures the propensity for sharing tacit knowledge; (IV) identification of the descriptive variables for the sharing phenomenon (age, career length, JEF time, the Federal Court Region, participation (or not) in events of interactive nature, participation in social networks of technical character, use of private personal communication devices (smartphones, tablets, etc.), agreement (or not) that sharing is essential to a judge's work); and the possibilities of: (V) checking the value and positive impact of VE on the indicator; (VI) estimation of individual propensity of a judge to share their tacit knowledge; and from that index, (VII) establishing the degree to which a judge is able to share, between (0.1); and (VIII) segment judges according to their propensity levels: (0-0.25), low level of sharing; (0.26 to 0.50$)$, moderate-low; $(0.51$ to 0.75$)$, moderatehigh; and (0.76 to 1.00$)$, high. In conclusion, it was possible: to identify which variables explained the propensity for tacit knowledge sharing, according to the proposed method, and to better assist JEF understand the flow of tacit knowledge associated with a judge.
\end{abstract}

Keywords: Tacit knowledge. Knowledge Sharing. Indicator. Court Administration. Judge. Brazilian Justice. 


\section{LISTA DE FIGURAS}

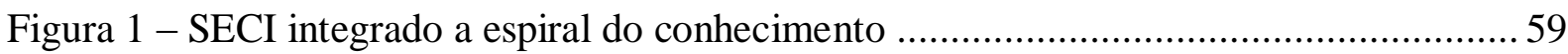

Figura 2 - As quatro categorias pessoais em organizações do conhecimento ........................ 62

Figura 3 - Política de Transferência de Informação ............................................................ 66

Figura 4 - Modelo de Compartilhamento de Conhecimento Tonet e Paz ............................. 67

Figura 5 - As relações do Engenheiro do Conhecimento ................................................ 73

Figura 6 - Organograma simplificado da Justiça Federal, com os JEF............................... 80

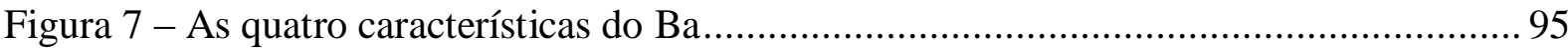

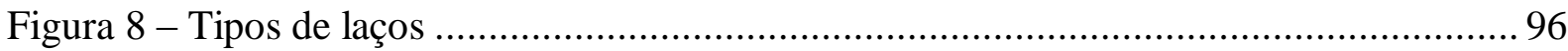

Figura 9 - Rede de Compartilhamento (teórica). .............................................................. 97

Figura 10 - Fluxo dinâmico em organizações intensivas em conhecimento ......................... 99

Figura 11 - Rede de Compartilhamento aplicada aos JEF............................................ 100

Figura 12 - Exemplos de gráficos de dispersão (nuvens de pontos) ................................. 119

Figura 13 - Matriz de dispersão das variáveis interativas (VInt) e o indicador .................... 120

Figura 14 - Faixas de relevância de interação quanto ao compartilhamento de conhecimento

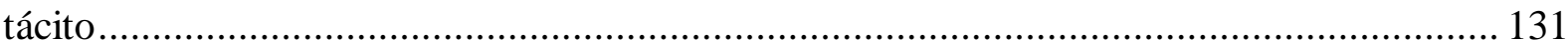

Figura 15 - Faixas de relevância quanto à intensidade de participação em eventos .............. 135

Figura 16 - Faixas de relevância quanto ao nível de concordância.................................... 140

Figura 17 - Resumo esquemático da pesquisa ........................................................... 156 


\section{LISTA DE GRÁFICOS}

Gráfico 1 - Série Histórica da Movimentação Processual da Justiça Federal (Casos novos

Casos pendentes Processos baixados).

Gráfico 2 - Despesas do Poder Judiciário com Informática (exceto STF e Conselhos - valores aproximados em $\mathrm{R} \$$ bilhões) 29

Gráfico 3 - Unidades Judiciárias de $1^{\circ}$ Grau da Justiça Federal ........................................ 82

Gráfico 4 - Gênero dos juízes (questão 1.2) ................................................................... 124

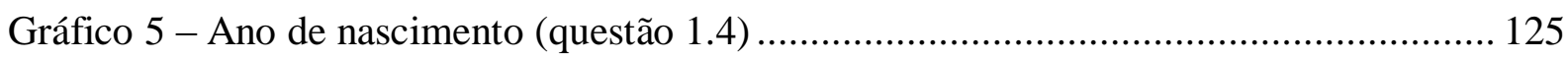

Gráfico 6 - Distribuição dos juízes por Região............................................................ 126

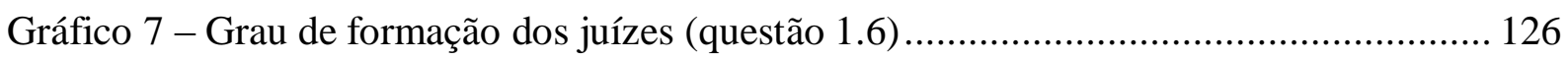

Gráfico 8 - Atuação dos juízes como docentes (questão 1.7) …...................................... 128

Gráfico 9 - Publicação de livros, capítulos, artigos (questão 1.8) …................................. 128

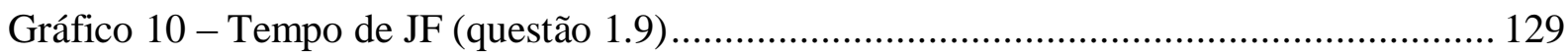

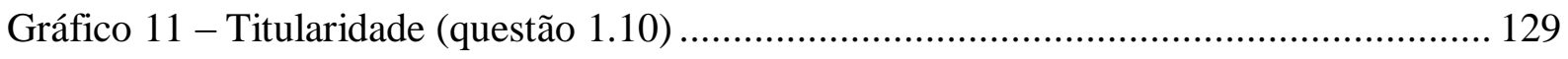

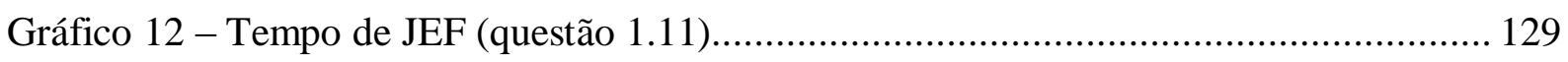

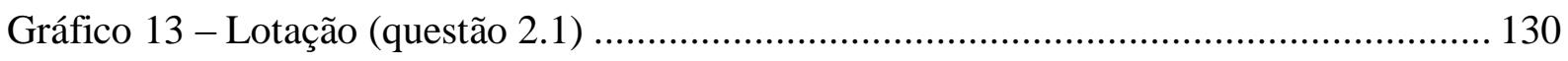

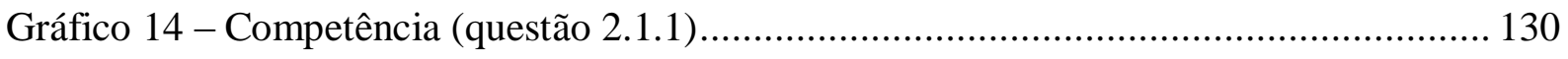

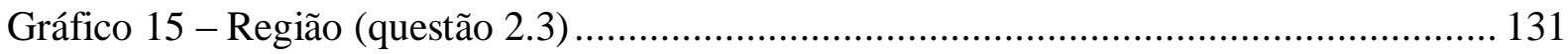

Gráfico 16 - Frequência de interação dos juízes com seus pares ...................................... 132

Gráfico 17 - Frequência de interação dos juízes com Agentes do Sistema de Justiça (ASJ) 133

Gráfico 18 - Frequência de interação dos juízes com servidores membros de sua equipe ... 134

Gráfico 19 - Frequência de participação do juiz em eventos de natureza presencial ........... 135

Gráfico 20 - Frequência de participação do juiz em eventos de natureza virtual ................. 136

Gráfico 21 - Participação dos juízes em rede social ...................................................... 137

Gráfico 22 - Emprego de tecnologia de comunicação particular para o compartilhamento de

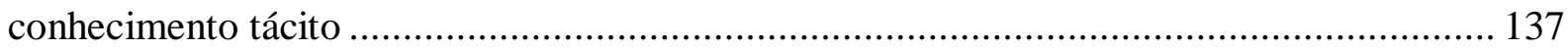

Gráfico 23 - Frequência de participação do juiz em eventos de natureza virtual ................. 139

Gráfico 24 - Nível de concordância de que o compartilhamento do conhecimento tácito é relevante para o desenvolvimento organizacional 140

Gráfico 25 - Nível de concordância de que o compartilhamento do conhecimento tácito é relevante para o desenvolvimento organizacional 
Gráfico 26 - Natureza do conhecimento tácito

Gráfico 27 - Impactos das variáveis sobre o indicador, segundo o Modelo (Beta Reduzido)

Gráfico 28 - Curva de densidade relativa aos indicadores de propensão ao compartilhamento (juízes da amostra) 148 


\section{LISTA DE QUADROS}

Quadro 1 - Identificação do fenômeno de compartilhamento em modelos de GC 38

Quadro 2 - Identificação de processos relacionados ao compartilhamento de conhecimento tácito

Quadro 3 - Representação do conhecimento tácito para o tácito (Socialização) 59

Quadro 4 - Representação dos conhecimentos tácito para o explícito (Externalização). 60

Quadro 5 - Representação dos conhecimentos explícito para o explícito (Combinação). 60

Quadro 6 - Representação dos conhecimentos explícito para o tácito (Internalização). 60

Quadro 7 - Quadro de fatores de sucesso para GC versus situação no TJ-PE. 69

Quadro 8 - Movimentação Processual dos JEF em âmbito nacional 84

Quadro 9 - Paradigma comparativo de princípios de uma organização do conhecimento dentro do contexto dos JEF

Quadro 10 - Questionamentos relativos à 'Frequência de interação' 104

Quadro 11 - Dimensões (D) e Variáveis Interativas (VInt) e hipotéticas (VH) 112

Quadro 12 - Graus de correlação 116

Quadro 13 - Resumo das etapas, estágios, atividades do método e objetivos específicos relacionados 122

Quadro 14 - Intervalos classificadores para a definição dos graus de compartilhamento..... 148 


\section{LISTA DE TABELAS}

Tabela 1 - Número de juízes interessados em conhecer os resultados da pesquisa 40

Tabela 2 - Grau de Correlação entre as VInt 116

Tabela 3 - Grau de correlação entre as variáveis e o i $\mathrm{iCT}_{\text {. }}$. 120

Tabela 4 - Gênero dos juízes (questão 1.2) 124

Tabela 5 - Composição por gênero do Tribunal de Justiça de São Paulo e do Tribunal Regional Federal $3^{\mathrm{a}}$ Região, segundo a instância e o gênero. 124

Tabela 6 - Ano de nascimento (questão 1.4) 124

Tabela 7 - Naturalidade - UF (questão 1.5) 125

Tabela 8 - Grau de formação dos juízes (questão 1.6) 126

Tabela 9 - Principais tipos de trabalho em que mestres e doutores estão ocupados, quanto ao grupo de grandes áreas do conhecimento $(\%)$. 127

Tabela 10 - Atuação dos juízes como docentes (questão 1.7) ........................................... 128

Tabela 11 - Publicação de livros, capítulos, artigos (questão 1.8) ..................................... 128

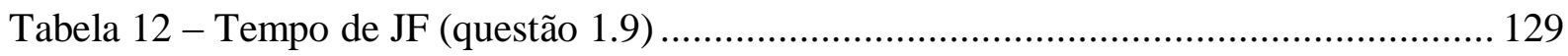

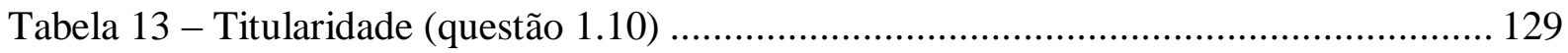

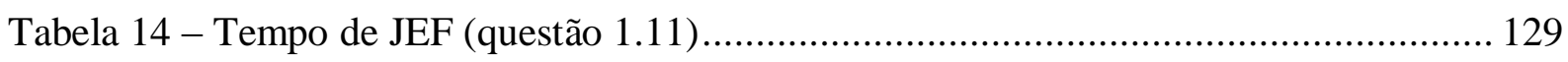

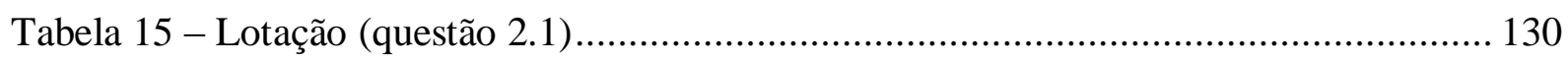

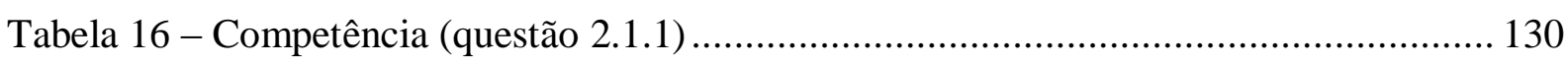

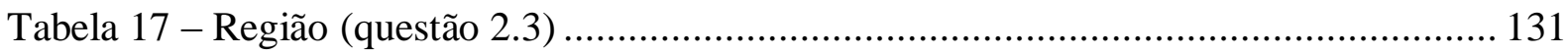

Tabela 18 - Frequência de interação dos juízes com seus pares ......................................... 132

Tabela 19 - Frequência de interação dos juízes com Agentes do Sistema de Justiça (ASJ) . 133

Tabela 20 - Frequência de interação dos juízes com servidores membros de sua equipe..... 134

Tabela 21 - Frequência de participação do juiz em eventos de natureza presencial ............. 135

Tabela 22 - Frequência de participação do juiz em eventos de natureza virtual ................... 136

Tabela 23 - Participação dos juízes em rede social........................................................ 137

Tabela 24 - Emprego de tecnologia de comunicação particular para o compartilhamento de

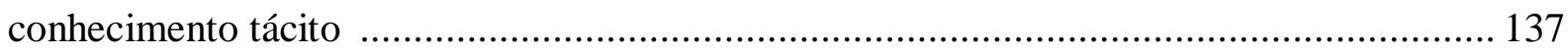

Tabela 25 - Indivíduos com os quais os juízes mais compartilha .................................... 138

Tabela 26 - Frequência de participação do juiz em eventos de natureza virtual .................. 139

Tabela 27 - Nível de concordância de que o compartilhamento do conhecimento tácito é relevante para o desenvolvimento organizacional 140 
Tabela 28 - Nível de concordância de que o compartilhamento do conhecimento tácito é relevante para o desenvolvimento organizacional

Tabela 29 - Natureza do conhecimento tácito 142

Tabela 30 - Impactos das variáveis sobre o indicador, segundo o Modelo (Beta Reduzido) 143

Tabela 31 - Grupo das variáveis explicativas (VE) iniciais 145

Tabela 32 - Variáveis relativas ao tempo como juiz e impactos sobre o indicador 146

Tabela 33 - Variáveis relativas à posição geográfica (Região) e impactos sobre o indicador 147

Tabela 34 - Indicadores dos juízes selecionados fora da amostra. 149

Tabela 35 - Graus de compartilhamento calculados para juízes selecionados fora da amostra, segundo o $\mathrm{i}_{\mathrm{CCT}}$. 


\section{LISTA DE SIGLAS}

\begin{tabular}{ll} 
AGU & Advocacia Geral da União \\
ASJ & Agentes do Sistema de Justiça \\
Caixa & Caixa Econômica Federal \\
CF & Constituição Federal \\
CI & Ciência da Informação \\
CJF & Conselho da Justiça Federal \\
CNJ & Conselho Nacional de Justiça \\
DPU & Defensoria Pública da União \\
EC & Emenda Constitucional \\
GC & Gestão do Conhecimento \\
INSS & Instituto Nacional de Seguridade Social \\
JEF & Juizados Especiais Federais \\
JF & Justiça Federal \\
MIT & Massachusetts Institute of Technology \\
MP & Ministério Público \\
P\&D & Pesquisa e Desenvolvimento \\
PJ & Poder Judiciário \\
RC & Rede de Compartilhamento \\
SERPRO & Serviço Federal de Processamento de Dados \\
STF & Supremo Tribunal Federal \\
STJ & Superior Tribunal de Justiça \\
TIC & Tecnologia da Informação e da Comunicação \\
TRE & Tribunal Regional Eleitoral \\
TRF & Tribunal Regional Federal \\
TRT & Tribunal Regional do Trabalho \\
TSE & Tribunal Superior Eleitoral \\
TST & Tribunal Superior do Trabalho \\
VBC & Visão Baseada em Conhecimento \\
VBR & Visão Baseada em Recurso \\
VE & Variável Explicativa \\
VH & Variável Hipotética \\
VInt & Variável Interativa \\
\hline
\end{tabular}




\section{SUMÁRIO}

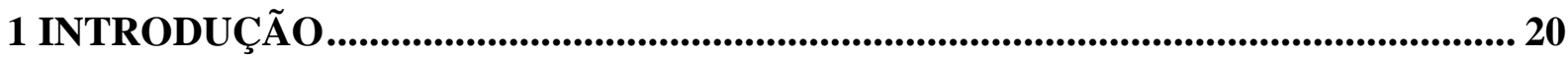

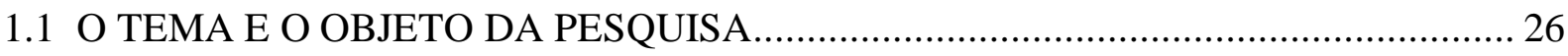

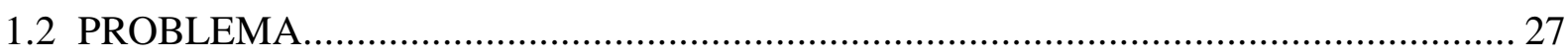

1.2.1 A problemática sentida .............................................................................................. 27

1.2.2 A problemática racional: a objetivação do problema da pesquisa ............................ 28

1.2.3 O problema enunciado......................................................................................................... 31

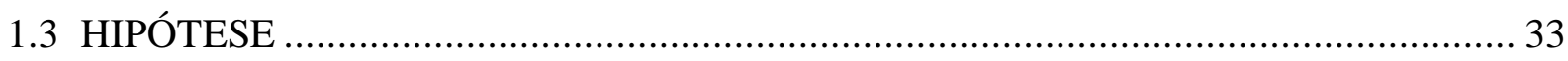

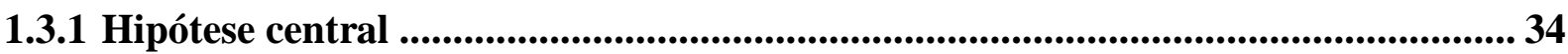

1.3.2 Hipóteses derivadas (com base na VH) ....................................................................... 34

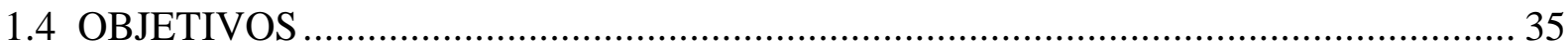

1.4.1 Objetivo Geral.................................................................................................................... 35

1.4.2 Objetivos Específicos ......................................................................................................... 36

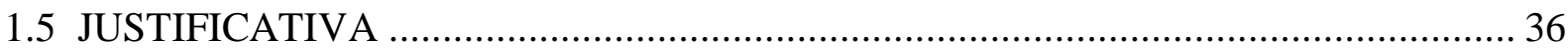

1.5.1 A condição daquele que observa e vive o problema....................................................... 36

1.5.2 A importância do compartilhamento do conhecimento tácito ......................................37

1.5.3 Inexistência de estudo sobre compartilhamento de conhecimento tácito no judiciário ....................................................................................................................................... 39

1.5.4 Interesse dos juízes pela aplicação da pesquisa ............................................................. 40

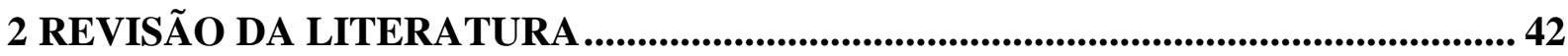

2.1 A TEORIA DO CRESCIMENTO, A VISÃO BASEADA EM RECURSOS (VBR) E O APARECIMENTO DA TEORIA BASEADA EM CONHECIMENTO. .............................. 43

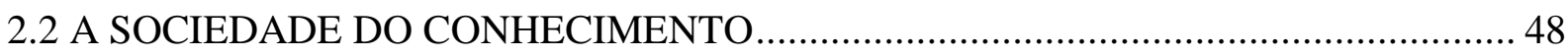

2.3 O CONHECIMENTO TÁCITO E O SEU COMPARTILHAMENTO ……….................. 51

2.4 TRABALHOS SELECIONADOS ACERCA DE COMPARTILHAMENTO DE

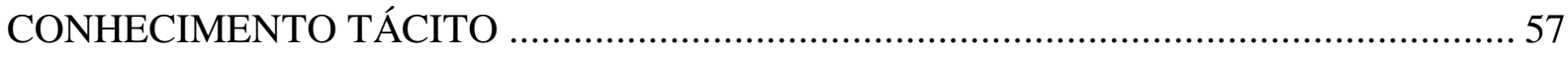

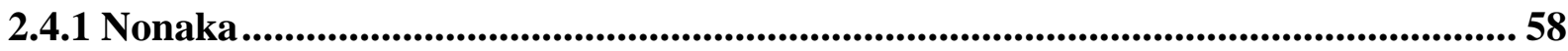

2.4.2 Sveiby ..................................................................................................................... 61

2.4.3 Davenport e Prusak .............................................................................................................. 64

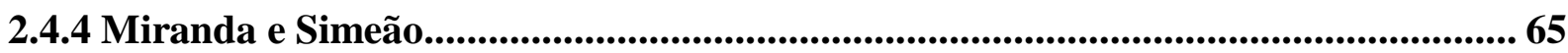

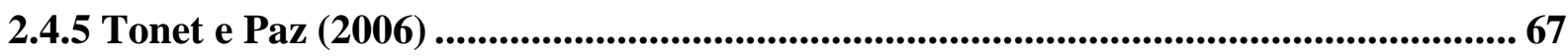




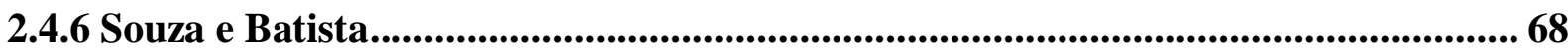

2.5 COMPARTILHAMENTO DE CONHECIMENTO NO JUDICIÁRIO .......................... 68

2.5.1 A comunidade de prática virtual como ferramenta da GC ...................................... 68

2.5.2 Paradigma para o Judiciário fluminense ........................................................... 70

2.5.3 Melhores práticas em uma base de dados no Tribunal Regional Federal da Primeira Região ...................................................................................................... 72

2.5.4 Modelo de conhecimento para apoio ao juiz na fase processual trabalhista........... 73

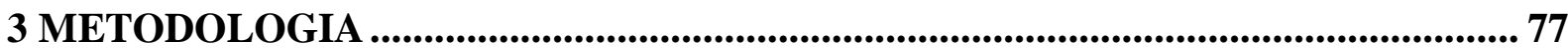

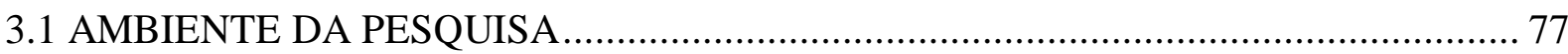

3.1.1 O Poder Judiciário ............................................................................................................ 77

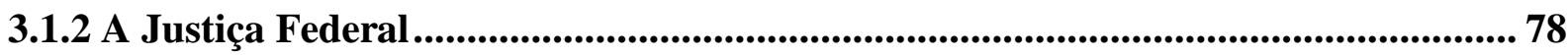

3.1.3 Os Juizados Especiais Federais (JEF) ........................................................................ 79

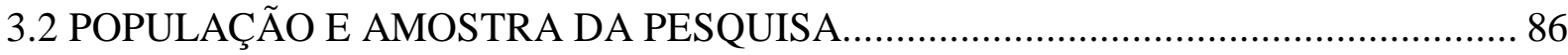

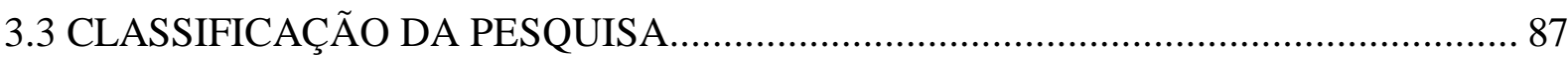

3.3.1 A fase descritiva................................................................................................................. 87

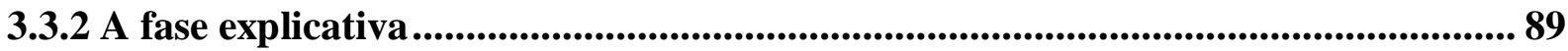

3.4 O MÉTODO PARA IDENTIFICAR AS VARIÁVEIS EXPLICATIVAS DO COMPARTILHAMENTO DO CONHECIMENTO TÁCITO............................................. 89

3.4.1 Etapa 1 - Identificação do agente central.................................................................. 90

3.4.2 Etapa 2 - Explicitação da rede de compartilhamento (RC) ..................................... 94

3.4.3 Etapa 3 - Mapeamento das possíveis dimensões e das variáveis explicativas, estabelecimento das hipóteses e elaboração do instrumento de coleta de dados e informações .................................................................................................................................... 100

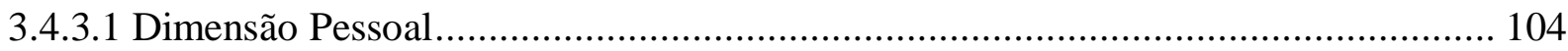

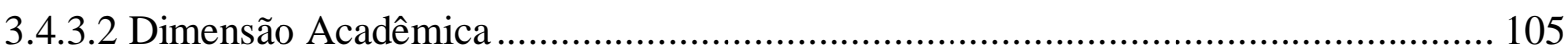

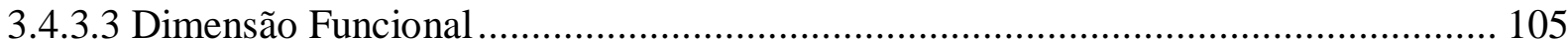

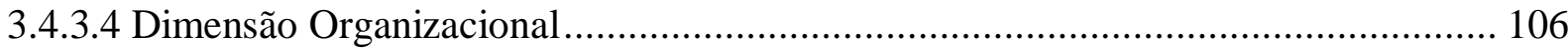

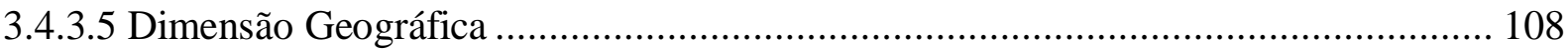

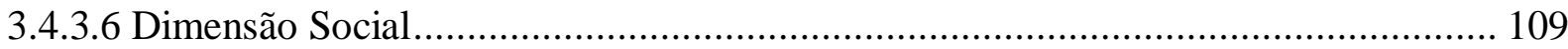

3.4.3.7 A validação do questionário de coleta de dados e informações ............................... 112

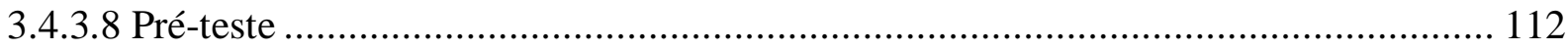

3.4.3.9 Abordagem junto aos Tribunais e juízes ...................................................... 113 
3.4.4 Etapa 4 - Criação da unidade de medida

3.4.4.1 Estágio 1 - a avaliação do grau de correlação entre as variáveis interativas (VInt) 115

3.4.4.2 Estágio 2 - Síntese das variáveis interativas (VInt) 117

3.4.4.3 Estágio 3 - Parametrização do indicador dentro do intervalo $(0,1)$. 117

3.4.4.4 Estágio 4 - Verificação do grau de correlação entre as variáveis e o indicador ..... 118 3.4.5 Etapa 5 - Estimação dos impactos das variáveis hipotéticas (VH) sobre do indicador e a identificação das variáveis explicativas (VE) ......................................... 121

4 RESULTADOS E DISCUSSÕES ................................................................................ 123

4.1 DADOS E INFORMAÇÕES COLETADOS DIRETAMENTE DAS RESPOSTAS DO

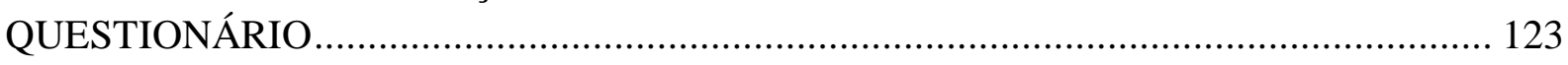

4.1.1 Dimensão Pessoal ........................................................................................... 123

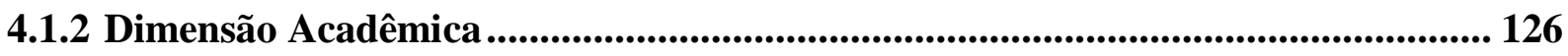

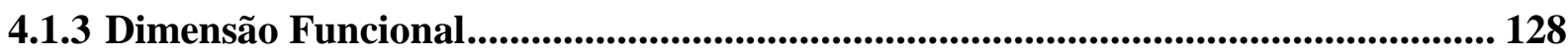

4.1.4 Dimensão Organizacional ..................................................................................... 130

4.1.5 Dimensão Geográfica ................................................................................. 130

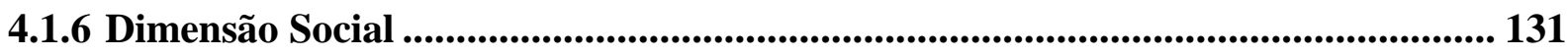

4.2 O EMPREGO DA UNIDADE DE MEDIDA ........................................................ 142

4.2.1 Identificação das variáveis explicativas (VE) ................................................. 142

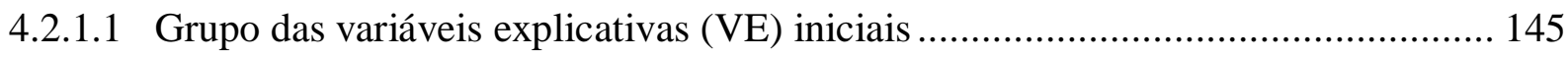

4.2.1.2 Grupo das variáveis explicativas (VE) relacionadas ao tempo de serviço .............. 146

4.2.1.3 Variável Posição Geográfica ...................................................................... 147

4.2.1.4 Estabelecimento de perfil de juízes com base no indicador ............................... 147

4.2.1.5 Atribuição de valor numérico à propensão individual (juízes fora da amostra) ...... 149

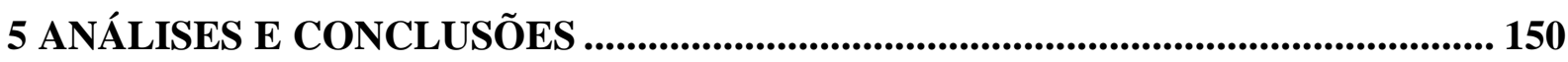

REFERÊNCIAS .................................................................................................. 157

APÊNDICE A - QUESTIONÁRIO APLICADO AOS JUÍZES DOS JEF ................... 172

APÊNDICE B - TAMANHO DA AMOSTRA POR ESTRATO............................... 176

APÊNDICE C - LISTA DOS JUÍZES SELECIONADOS NA AMOSTRA E AS CIDADES ONDE ESTÃO LOCALIZADAS AS VARAS.......................................... 177 APENDICE D - CARTA DA ORIENTADORA SOLICITANDO ENCAMINHAMENTO DO LINK-QUESTIONÁRIO AOS JUÍZES COM OS ELEMENTOS DA PESQUISA ........................................................................... 180 
APÊNDICE E - QUESTIONÁRIO ADAPTADO ÀS VARIÁVEIS EXPLICATIVAS PARA CÁLCULO DO ICCT

ANEXO A - COMPETÊNCIA E ATRIBUIÇÕES DOS JUÍZES QUANDO NO EXERCÍCIO DAS FUNÇÕES DE DIRETOR DO FORO DAS SEÇÕES JUDICIÁRIAS

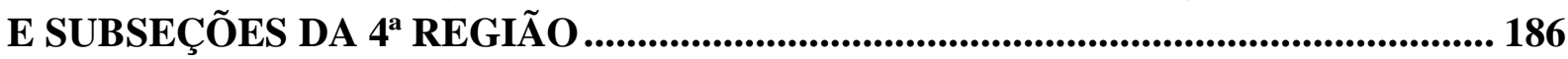
ANEXO B - DOCUMENTO AUTORIZATIVO DE REALIZAÇÃO DA PESQUISA (TRF1) 191 ANEXO C - DOCUMENTO AUTORIZATIVO DE REALIZAÇÃO DA PESQUISA (TRF2) 192 ANEXO D - DOCUMENTOS AUTORIZATIVOS DE REALIZAÇÃO DA PESQUISA (TRF3) 193 ANEXO E - DOCUMENTO AUTORIZATIVO DE REALIZAÇÃO DA PESQUISA (TRF4) 194 ANEXO F - DOCUMENTO AUTORIZATIVO DE REALIZAÇÃO DA PESQUISA (TRF5) 195

ANEXO G - PLANO DIRETOR E PRIMEIRAS AÇÕES DIRETRIZES (TJ-RJ)..... 196 ANEXO H - VISITAS EXTERNA REALIZADAS PELO TJ-RJ COM O PROPÓSITO DE COMPARTILHAR CONHECIMENTOS. 197 ANEXO I - METAS DO CONSELHO NACIONAL DE JUSTIÇA (CNJ) PARA 2016198 


\title{
1 INTRODUÇÃO
}

\begin{abstract}
Não deixa de surpreender, portanto, o contraste que se observa entre, de um lado, o grau de insatisfação com o Judiciário e a importância e urgência que se atribui a melhorar o seu funcionamento e, de outro, o pouco conhecimento disponível sobre esse poder. Dos três ramos do governo, o Judiciário é, certamente, o menos estudado. E essa constatação se aplica tanto às ciências sociais das democracias avançadas como àquelas do Terceiro Mundo. Nas últimas, no entanto, a situação é mais séria, já que praticamente não há tradição de estudos científicos sobre o Judiciário - lacuna especialmente grave no caso do Brasil. (PINHEIRO, 2002, p.5).
\end{abstract}

O Judiciário, principalmente a partir da década de 1990, tem sido palco de inúmeros exames e transformações. A busca por diminuir o seu acervo de julgamento, colocar à disposição de seu público interno ferramentas tecnológicas e práticas eficazes, bem como levar qualidade ao cidadão e às instituições sociais, vem requerendo também por parte de pesquisadores e da academia um olhar particular e investigativo e um apontamento de possíveis e prósperos caminhos.

A entrada do pesquisador no ambiente judiciário, como Analista, permitiu que essa realidade fosse conhecida. Diferentemente das Forças Armadas ${ }^{1}$, onde esse tema é caro, o Poder Judiciário trazia (e traz) algo de peculiar e instigante. Durante os trabalhos realizados nos últimos 19 anos, aspectos relacionados ao trato da informação e mais ainda do conhecimento estiveram presentes.

Dentre as análises desenvolvidas, destacam-se: na Seção de Modernização Administrativa da Justiça Federal no Estado do Amazonas (SEMAD-AM), a melhoria dos fluxos de trabalhos a partir do emprego de conhecimento tácito de antigos e experientes servidores.

As atividades desenvolvidas no Núcleo de Coordenação dos JEF do Distrito Federal (NUCOD-DF) permitiram, novamente, a condensação de conhecimento tácito no mapeamento de rotinas judiciais e na cartilha ao cidadão.

No Centro de Estudos e Apoio à Gestão Organizacional (CENAG), hoje, Secretaria de Gestão Estratégica e Inovação (SECGE) do Tribunal Regional Federal da $1^{\text {a }}$ Região (TRF1), local de lotação do pesquisador, a informação e principalmente o conhecimento, alternaram-se como fatores críticos para a gestão judiciária, envolvendo o planejamento estratégico e a elaboração de projetos corporativos.

\footnotetext{
${ }^{1} \mathrm{O}$ autor, antes de pertencer aos quadros do Judiciário, era oficial Fuzileiro Naval, da Marinha do Brasil.
} 
O cenário das transformações tecnológicas e a necessidade do aprimoramento constante dos serviços judiciais requereu uma Emenda Constitucional, concretizada pela de número 45 (EC 45), de 08.12.2004 que tratava da reforma do Judiciário (BRASIL, 2004).

A emenda atuou exatamente nas "Garantias Fundamentais" e nos "Direitos Coletivos". Àquilo que se constitui a base da sociedade brasileira, adicionou-se o conceitonúcleo da reforma: a velocidade na entrega efetiva do direito, traduzida pelas expressões "razoável duração" e "celeridade".

Art. $5^{\circ}$ Todos são iguais perante a lei, sem distinção de qualquer natureza, garantindo-se aos brasileiros e aos estrangeiros residentes no País a inviolabilidade do direito à vida, à liberdade, à igualdade, à segurança e à propriedade, nos termos seguintes:

LXXVIII a todos, no âmbito judicial e administrativo, são assegurados a razoável duração do processo e os meios que garantam a celeridade de sua tramitação. (BRASIL, 1988, p. 1, grifo nosso).

Tal foi a magnitude da reforma que entendeu o Governo brasileiro ser necessária a criação de uma nova estrutura de Estado, o Conselho Nacional de Justiça (CNJ). Esta instituição visa aperfeiçoar o trabalho do sistema judiciário brasileiro, principalmente no que diz respeito ao controle e à transparência administrativa e processual, à elaboração e aprovação anualmente das Metas para o Judiciário, associadas a indicadores de resultado (Anexo I), e a proposição da Diretriz Estratégica anual ${ }^{2}$ que para 2016 traduziu-se em:

É diretriz estratégica do Poder Judiciário, e compromisso de todos os tribunais brasileiros, dar concretude aos direitos previstos em tratados, convenções e demais instrumentos internacionais sobre a proteção dos direitos humanos. (BRASIL, 2016, p. 1).

No campo da Gestão Estratégica, o CNJ define o planejamento e os programas de avaliação institucional do Poder Judiciário. Na Eficiência dos Serviços Judiciais, preza por melhores práticas e celeridade, e elabora e publica indicadores pertinentes à atividade jurisdicional em todo o País. Anualmente, edita o relatório "Justiça em Números".

Os dados constantes do Relatório Justiça em Números são a principal fonte estatística que o CNJ e os tribunais utilizam para sua atuação institucional. As informações sistematizadas e analisadas possibilitam um conhecimento amplo do Judiciário, capaz de fomentar medidas de integração, redução das disparidades regionais, bem como considerações sobre as especificidades dos desafios a serem enfrentados por cada ramo judicial no aprimoramento da prestação jurisdicional (BRASIL, 2014a, p. 5).

A reforma tentava, de certa forma, responder a inúmeras críticas dirigidas ao Judiciário.

\footnotetext{
${ }^{2}$ Os presidentes ou representantes dos tribunais do país, reunidos em Brasília/DF, nos dias 24 e 25 de novembro de 2015, durante o $9^{\circ}$ Encontro Nacional do Poder Judiciário, aprovaram a Diretriz Estratégica para orientar a atuação do Judiciário brasileiro em 2016.
} 
Cronologicamente apresentados em um período de dez anos, as citações a seguir refletem opiniões advindas de exames concernentes ao estado desse Poder.

Para Pinheiro (2002, p. 3), “o Judiciário brasileiro é uma instituição com problemas sérios [...] permanece lenta e distante da grande maioria da população".

Selem (2004, p. 15) atesta que "adjetivos como [Justiça] morosa, lenta, pouco eficiente, burocrática, [...] inacessível, [...] desorganizada administrativamente, estruturalmente obsoleta [...] são comumente atribuídos ao Judiciário brasileiro".

Sadek (2004) já anunciava que reformas viriam, que mudanças já estavam em curso, que o Judiciário encontrava-se na berlinda e que não poderia impedir mudanças. Mudanças estas diferentes de soluções 'mais do mesmo': mais juízes, mais tribunais, mais computadores, mais prédios, mais servidores (JOBIM, 2005), pois não faltam projetos relacionados ao Judiciário (NALINI, 2008).

Há que se considerar que "a lentidão, reconhecida por juízes e empresários como o principal problema no âmbito do Judiciário, impacta a economia e afeta o crescimento do país como um todo" (SILVEIRA, 2007, p. 44).

Programas e projetos acontecem com frequência como meio de o Judiciário contrapor-se ao conceito de que "O Brasil possui atualmente uma Justiça lenta, burocrática, arcaica, despreparada e ineficiente" (FONSECA, 2009, p. 12), contudo, "não há como esconder as deficiências dos serviços judiciários, a complicação e a morosidade de seus trâmites" (MIRANDA; MORESI, 2010, p. 409).

Em pesquisa de avaliação do Judiciário, a Fundação Getúlio Vargas verificou que para $89 \%$ dos entrevistados, o Judiciário resolve os conflitos de forma lenta ou muito lentamente (CUNHA et al., 2010, p. 9). A morosidade retorna pela crítica de Grangeia (2011) quando ele associa tal deficiência com a operação ineficaz da gestão dos recursos e a incapacidade gerencial de equacionar soluções efetivas.

Para um rápido processamento judicial, por exemplo, medidas emergenciais foram implantadas, como a instituição do Gabinete Criminal de Crise no Poder Judiciário do Paraná, criado para enfrentar e solucionar, de forma célere, situações decorrentes do quadro apontado (PARANÁ, 2012).

O Poder Judiciário sofre os impactos de uma nova configuração social, baseada em redes, fluxos e compartilhamento da informação e do conhecimento, com um público mais esclarecido sobre as funções desse Poder e desejoso de respostas rápidas. 
O índice que analisa e avalia o desempenho de poderes judiciários em vários países (The World Justice Project Rule of Law Index 2015) ${ }^{3}$ classificou o Brasil na 46 a posição (Ranking Global), na $48^{\mathrm{a}}$ para Justiça Civil (Fator 7) e $68^{\mathrm{a}}$ para Justiça Criminal, algo que requer reflexão e busca de novos caminhos.

No âmbito da Justiça Federal não é diferente. Em 2013, apesar ter julgado 3,8 milhões de processos, 8,1 milhões permaneceram em tramitação. No quinquênio (2009-2013) aumenta a litigiosidade. Os casos novos cresceram 3,1\%; os processos em tramitação, 5,7\%. (BRASIL, 2014a). A Série Histórica da movimentação processual apresentada no Gráfico 1 traz o tamanho do acervo. Os casos pendentes ( 8,1 milhões) equivalem a mais que a soma do total de casos novos (3,4 milhões) com o total de processos baixados (3,8 milhões).

\section{Gráfico 1 - Série Histórica da Movimentação Processual da Justiça Federal (Casos novos Casos pendentes Processos baixados)}

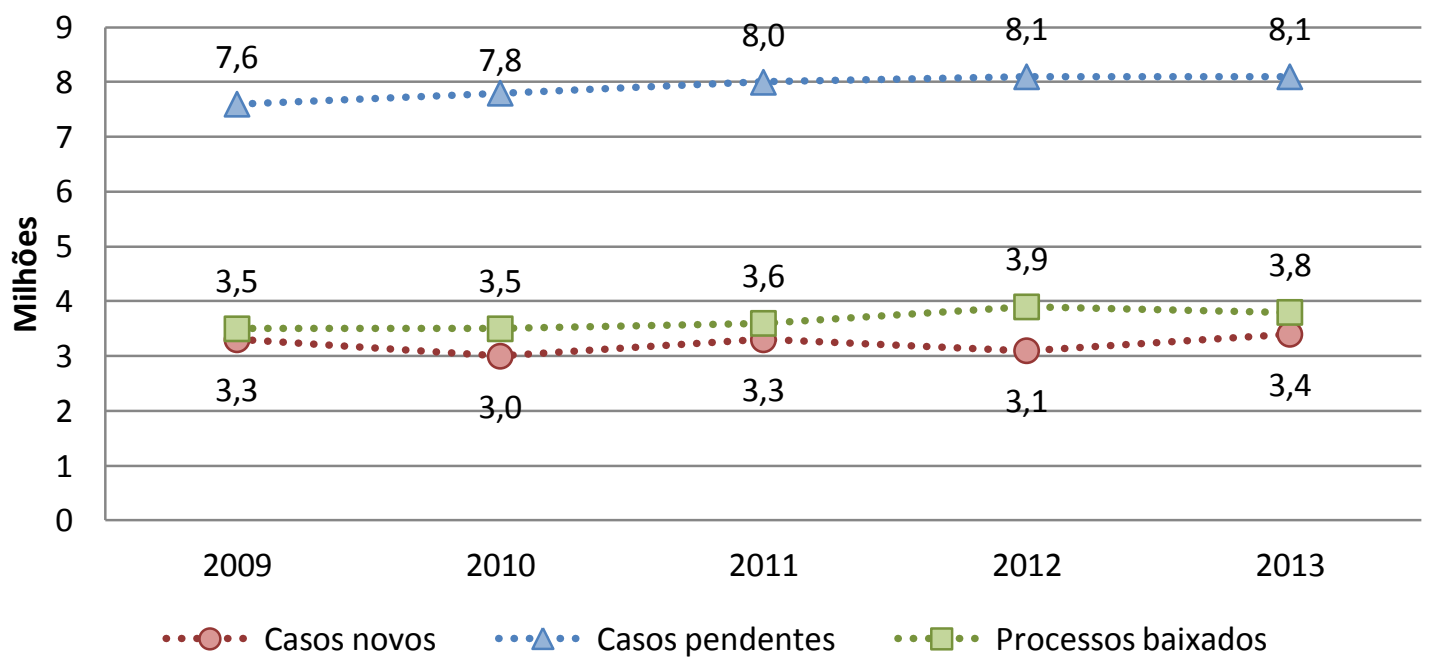

Fonte: BRASIL (2014a).

Conforme o gráfico, parece que o Judiciário Federal carecia (e ainda carece) de alguma alavancagem em seu desempenho, seja para impedir o avanço, seja para mitigar os efeitos da crise que atravessa.

Dado o volume de casos que enfrenta e precisa decidir com celeridade e o esforço já realizado ano após ano, a pesquisa sugere uma nova possibilidade, associada, como se verá, ao aprimoramento institucional, o compartilhamento do conhecimento tácito.

Durante a pesquisa, o compartilhamento de conhecimento tácito foi visto e tratado como um fenômeno: a) "fato constatado que constitui matéria das ciências" (LALANDE,

\footnotetext{
3 Índice que mede o estado de Direito baseado em experiência e percepções do público em geral, incluindo especialistas de diversos países do mundo. (WORLD JUSTICE PROJECT, 2015).
} 
1999, p. 394), caracterizado por suas interações sociais, na forma presencial ou remota; e b) demonstração do conhecimento humano que aparece em condições particulares (ABBAGNANO, 2007), acompanhando Nissen e Levitt (2002, p. 5) que se referem ao compartilhamento como um "fenômeno de fluxo de conhecimento" e Borgatti e Li (2009, p. 7), como um "fenômeno relacional".

No acompanhamento desse fenômeno, por ocasião de encontros (presenciais e virtuais) entre juízes de Juizados Especiais Federais (JEF) ${ }^{4}$, percebeu-se que havia indivíduos que apresentavam um notável grau de compartilhamento (principalmente, pelo uso da conversa); outros, porém, dedicavam-se a simples interações (às vezes, de forma remota, com emprego de aparelhos de comunicação) ou permaneciam mais reservados.

Os questionamentos iniciais que se fizeram, então, foram: Os juízes de JEF do Brasil compartilham conhecimento tácito? Uma primeira resposta a esta indagação foi "sim", pois, em 2002, um ano após a criação dos JEF pela Lei n. ${ }^{\circ} 10$ 259, de 12 de julho de 2001, o Conselho da Justiça Federal (CJF) planejou a realização do Encontro: Juizados Especiais Federais, avaliação e propostas de melhoria com o fim de oportunizar

o intercâmbio de experiência entre os juízes que atuam nos Juizados Especiais Federais, para que soluções bem-sucedidas, implementadas em uma determinada Região, pudessem ser conhecidas e adotadas por outras. (BRASIL, 2003, p. 11).

Este questionamento, no entanto, foi assumido como uma premissa do trabalho e gerou a hipótese central da pesquisa (item 1.3.1).

Outra indagação, Que variáveis poderiam explicar esse fenômeno?, serviu de base para a formulação das hipóteses derivadas (item 1.3.2).

Considerado os JEF em âmbito nacional como lócus da pesquisa, o estudo, amparado pela literatura, averiguou o compartilhamento de conhecimento tácito e verificou ser possível estabelecer conexões entre a figura do juiz (agente central do sistema JEF) e outros indivíduos que participam de uma rede de relações interativas: os seus pares, um grupo de agentes externos e membros da sua equipe de trabalho.

$\mathrm{O}$ arranjo de relações de intercâmbio de conhecimento foi tratado por Rede de Compartilhamento (RC) e, no caso dos JEF, assumiram-se, como pares, outros juízes; como agentes externos, os Agentes do Sistema de Justiça (ASJ), isto é, membros do Ministério Público e das Advocacias Privada e Pública; e como equipe, os servidores que compunham as unidades de trabalho dos juízes (Varas e Turmas Recursais).

\footnotetext{
${ }^{4}$ Os JEF serão melhor apresentados no item 3.1.3, Seção 3.1 Ambiente de Pesquisa.
} 
Para descrever e explicar o fenômeno do compartilhamento do conhecimento tácito dos juízes, foi selecionado um conjunto de variáveis interativas (VInt) e hipotéticas (VH). Dentre as hipotéticas, as de caráter particular (gênero, idade, formação acadêmica entre outros) e as de natureza comum (como titularidade do juiz, competência e localização geográfica da vara, uso de aparelhos privados de comunicação, entre outros) que compuseram a hipótese da pesquisa. As VInt trataram de mensurar a frequência de interação entre os membros da RC.

Com a integração dos dados e informações provenientes dos respondentes, houve a necessidade da criação de um método efetivo para a identificação das variáveis que explicassem o fenômeno. Esse método tornou-se um dos importantes subprodutos da pesquisa.

Como parte do método, formulou-se uma unidade de medida de cunho numérico, tratada por indicador, capaz de, segundo a percepção dos juízes de JEF: a) avaliar o impacto trazido por cada variável prevista nas hipóteses sobre a propensão dos juízes em compartilhar; e b) mensurar um valor numérico individual para a propensão dos juízes em compartilhar seus conhecimentos tácitos. Da mesma forma que o método, o indicador, pelo seu grau de inedidismo, também foi tido como um achado de relevo.

Em razão de o fenômeno possibilitar a associação de muitas variáveis (e suas relações), técnicas estatísticas foram empregadas e análises descritivas e explicativas foram desenvolvidas.

O objetivo da pesquisa foi o de identificar as variáveis que explicam o fenômeno do compartilhamento de conhecimento tácito no ambiente dos JEF consoante a perspectiva dos juízes.

Alcançado o objetivo, o trabalho apresentou ainda quatro conquistas. A primeira foi resultado da proposição de uma nova unidade de medida para a propensão de compartilhamento de conhecimento tácito cuja sugestão denominativa é anyi, uma referência a Polanyi ${ }^{5}$ (2009). A segunda caracterizou-se pela possibilidade de se apontar as variáveis que explicam o compartilhamento segundo a visão dos sujeitos amostrais, os juízes dos JEF.

A terceira conquista despontou quando se viu permitida a mensuração do impacto causado por cada variável, negativa ou positivamente, sobre o compartilhamento ${ }^{6}$. A quarta

\footnotetext{
${ }^{5}$ A sugestão, então, seria a de empregar essa proposta de unidade para mensurar o grau de compartilhamento de conhecimento tácito, exemplo: a propensão do juiz A em compartilhar o seu conhecimento tácito é 0,77 anyi.

${ }^{6}$ Considerando o fator geográfico, um dos achados do estudo, juízes pertencentes a regiões diferentes, tendem a compartilhar de forma distinta.
} 
conquista apresentou-se quando se revelou possível o cálculo do valor numérico referente à propensão individual de cada juiz ao compartilhamento.

Os resultados obtidos puderam ainda ser relacionados a alguns possíveis benefícios de ordem organizacional. No nível operacional, verificou-se que o fato de o juiz empregar alguma tecnologia de comunicação de propriedade particular (smartphone, iphones, tablets, ipads, outros) para partilhar suas ideias impactou positivamente o compartilhamento, isto é, tendeu a compartilhar mais. No patamar gerencial, abriram-se possibilidades para a área de Gestão de Recursos Humanos ao se verificar que após os anos iniciais de judicatura, quanto maior o tempo de juiz, maior a propensão em compartilhar.

No âmbito estratégico, vislumbrou-se a possibilidade da inserção de uma política de mudança cultural, já preconizada pelo Ministro do STJ, Ruy Rosado do Aguiar quando, no momento de criação dos JEF, advertia sobre a necessidade de ocorrer uma "reforma da mentalidade de todos os que participarão dos Juizados "7" (BRASIL, 2000, p. 9).

Assim, a quarta conquista pode incitar a liderança judiciária a conceber uma estratégia institucional baseada em um dos resultados desta pesquisa, o de que a propensão a compartilhar tendeu a aumentar quando os juízes concordam que o compartilhamento de conhecimento é imprescindível para o melhor exercício de sua atividade judiciária.

Alguns comentários a respeito das limitações da pesquisa estão inseridos ao final da obra, desde as derivadas do próprio método até as de caráter pessoal dentro da subjetividade do autor, pois

$\mathrm{Na}$ escolha do tema, dos entrevistados, no roteiro de perguntas, na bibliografia consultada e na análise do material coletado, existe um autor, um sujeito que decide os passos a serem dados. (GOLDENBERG, 2005, p. 14).

\subsection{O TEMA E O OBJETO DA PESQUISA}

Se você já construiu castelos no ar, não tenha vergonha deles. Estão onde devem estar. Agora, dê-lhes alicerces. Thoreau (apud HENRY..., 2014), naturalista e escritor norte-americano 1817-1862.

O conhecimento representa um recurso tão crítico para a moderna dinâmica das organizações que Grant (2011) interpreta-o como elemento central na busca de uma vantagem competitiva, o que equivaleria a tê-lo como um fator de expressão na gestão dos recursos e no processo de alcance dos objetivos estratégicos.

7 O termo "juizado", empregado pelas leis que instituíram os Juizados Especiais Cíveis e Criminais, da Justiça Ordinária (Lei n. ${ }^{\circ} 9$ 099, 26.09.1995) e da Justiça Federal (Lei N. ${ }^{\circ} 10$ 259, de 12.07.2001), foi mantido quando se deu a citação literal. A pesquisa, contudo, para se referenciar aos juizados, repartição onde trabalham o juiz e seus servidores, utilizou da expressão "Vara JEF" ou simplesmente "Vara". 
Para Nissen e Levitt (2002), o conhecimento tácito apresenta-se como um ativo de valor para a organização, embora ainda compartilhado de forma desigual.

Essa constatação ganhou peso quando se acompanhou o compartilhamento de conhecimento tácito entre juízes de JEF durante encontros de natureza interativa.

Notou-se, assim, ser factível uma contribuição da Ciência da Informação para a interpretação do compartilhamento do conhecimento tácito, consoante um mapeamento das possíveis variáveis explicativas desse fenômeno.

Dessa forma, assumiu-se como tema o conhecimento e como objeto o fenômeno e as variáveis que pudessem explicá-lo, segundo a perspectiva dos juízes de JEF.

\subsection{PROBLEMA}

O que funcionava ontem pode não ser solução para os problemas de hoje ou talvez não sirva para aproveitar as oportunidades de amanhã. William James (UNISANTA, 2004, p. 1), psicólogo, 1842-1910.

\subsubsection{A problemática sentida}

O pesquisador, não raramente, no meio em que vive e pensa, reúne fatos, teorias, suposições, conceitos e valores. Sob determinado arranjo, tais elementos podem fazê-lo perceber determinado fenômeno e, por vezes, um problema (LAVILLE, 1999).

Os conteúdos que inquietaram o pesquisador foram formados a partir da possibilidade de que o conhecimento mental incorporado à pessoa do juiz, ao ganhar mobilidade, pode trazer inovação e aprimorar as rotinas judiciais.

$\mathrm{O}$ exame da crise, somado às possibilidades de rotas alternativas baseadas na Ciência da Informação, fizeram emergir o que Laville (1999) trata por problemática sentida.

O quadro de crise constituído reflete a lentidão em apresentar soluções aos litígios. No contexto, contabilizam-se, cada vez mais, apreciações negativas dirigidas ao Judiciário. Somam-se à crítica os advogados particulares, os procuradores e defensores institucionais, os membros do Ministério Público, os servidores, os magistrados e o público em geral.

Há várias explicações e teorias para a demora na prestação jurisdicional, principal reclamação. Entre outras reclamações, enumeram-se: a volumosa e crescente entrada de ações judiciais $^{8}$, a pequena quantidade de recursos humanos, os modelos de gestão ultrapassados e a ineficiente aplicação da tecnologia da informação e da comunicação (TIC).

\footnotetext{
${ }^{8}$ Pelo relatório Justiça em Números, tramitaram ao longo de 2011 quase 90 milhões de processos.
} 
Tais fatos pertencem à problemática, ocorrem dentro do Judiciário e podem afetar $\mathrm{o}$ conhecimento que circula na organização e os processos de inovação requeridos (NONAKA; TAKEUCHI, 1997).

Da perspectiva dos usuários internos, não raramente, tem-se notícia de que determinada solução exitosa aplicada em determinado órgão ou unidade não se encontra aplicado em outro, às vezes, vizinho. Dessa forma, parece que o conhecimento não circula e ganhos substantivos em determinados processos de trabalho não são transferidos a outros, assim como modelos, teorias e hipóteses, tacitamente alojados, não encontram mentes e ambientes adequados para a sua difusão.

O panorama desenhado pelos clientes externos não é diferente. Apontam os grandes litigantes, operadores do Direito e jurisdicionados como um todo que a interação com determinados TRF faz-se mais ágil e cômoda, quando levado em consideração a unidade da federação.

Parece que, para os que buscam proteção de seus direitos e a presença resolutiva do Estado, o recebimento do direito na forma como prega a EC 45, como se viu, deve independer da região do país.

A legitimidade do Judiciário também passa em sê-lo e mantê-lo como um Poder técnico (MOREIRA NETO, 1999), na visão do pesquisador, tão aperfeiçoado no estudo e na prática da ciência do Direito, como no da Ciência da Informação.

\subsubsection{A problemática racional: a objetivação do problema da pesquisa}

Inicialmente, entendeu-se a morosidade do Poder Judiciário como sendo o problema da pesquisa. Mas, sob uma reflexão mais detida, somada a outros conhecimentos e análises ${ }^{9}$, procurou-se sair do campo das consequências e buscar as causas. Dessa experiência, percebeu-se que o projeto organizacional é na realidade um aglomerado de conhecimentos provenientes da dinâmica do empreendimento.

É sabido que o Poder Judiciário tem a sua missão suportada por um fluxo contínuo de conhecimento, seja no formato tácito ou explícito. O primeiro, abarca todo o conteúdo que se encontra na mente das pessoas. O segundo, abrange aquilo que foi produzido pelo ser humano e encontra-se externo a sua mente em forma de registro.

\footnotetext{
9 O autor tratou do tema "Qualidade em ambiente judiciário" por ocasião de sua dissertação de mestrado (FERRETTI, 2001) e teceu em artigo algumas considerações acerca da Reforma do Poder Judiciário (FERRETTI, 2004).
} 
No rito judicial, em termos gerais, a parte autora (ou advogado/defensor) emprega o conhecimento tácito para explicitar o seu pedido inicial. O juiz por sua vez utiliza "o [seu] conhecimento tácito para analisar o direito e confeccionar a sentença” (RUSCHEL, 2012, p. 100).

Esse fluxo é o processo mais crítico e, simultaneamente, o eixo do "negócio judicial". No entanto, não obstante esse processo revigorar-se continuamente em intensidade e complexidade, demandando maior velocidade, acessibilidade e transparência, as iniciativas parecem ter-se prendido mais em disponibilizar e modernizar o parque tecnológico, com mais ênfase nos conhecimentos já explicitados, passíveis de serem codificados e processados, em detrimento dos conhecimentos tácitos e de sua mobilidade.

A verdade é muito mais complexa. Uma tecnologia melhor não pode resolver o problema. [...] o fato é que estamos falando de uma postura administrativa há muito existente. O erro não está, como Shakespeare bem poderia observar, no software, e sim, em nós mesmos. (WANG, 1998, p.2).

O gráfico 2 apresenta os valores agregados anualmente com despesas em aquisições, custeio e contratos em TIC: software (pronto), hardware, custo de funcionamento e de manutenção, abrangendo as despesas com compras de suprimentos, despesas de pessoal com servidores do quadro efetivo e não efetivo, terceirizados, estagiários, diárias, deslocamentos, cursos de capacitação e treinamento, inclusive as despesas empenhadas e inscritas em "restos a pagar" (BRASIL, 2009) ${ }^{10}$.

\section{Gráfico 2 - Despesas do Poder Judiciário com Informática (exceto STF e Conselhos - valores aproximados em $\mathbf{R}$ \$ bilhões)}

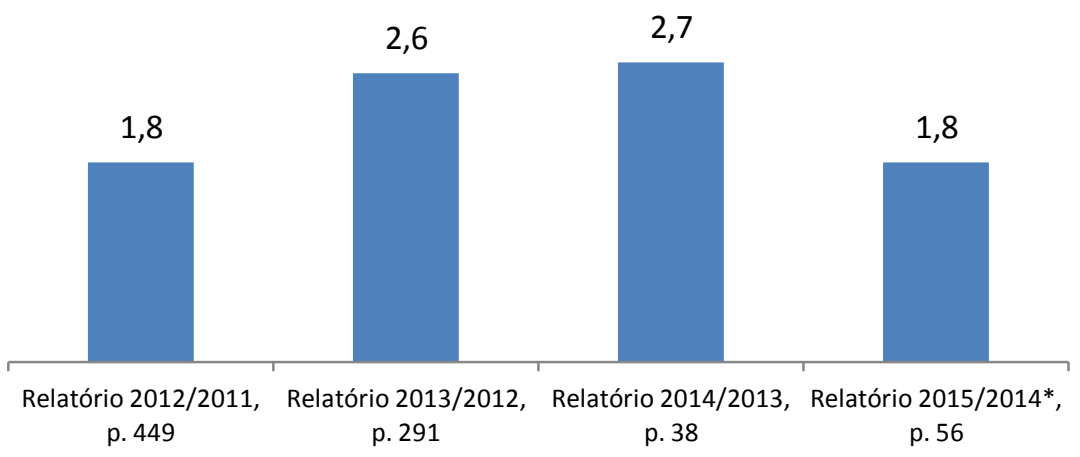

Fonte: Relatórios "Justiça em Números" (2012, 2013, 2014a, 2015).

Nota: *No cálculo dos valores referentes à 2014 (Relatório 2015/2014), foram retiradas algumas despesas anteriormente computadas nos Relatórios 2014, 2013 e 2012. O valor destas despesas soma aproximadamente R $\$ 1,1$ bi. Se consideradas, o valor de despesas com Informática alcançaria em 2014, R \$ 2,9 bi.

\footnotetext{
${ }^{10}$ O glossário referente à Resolução no 76/2009 apresenta essas despesas dentro de "Recursos Financeiros", por meio das siglas DInf1, DInf2, DInf3.
} 
No que diz respeito à compreensão do conhecimento como recurso estratégico a cultura do Judiciário parece assumir o seu conceito dentro do contexto da tecnologia da informação. Demandas de conhecimento são entendidas como demandas por soluções de TIC. Análises gerenciais, situacionais ou de inteligência estratégica reclamam ferramentas tecnológicas e pouco se vê na agenda dos executivos judiciais ações e projetos que discutam o conhecimento como ativo intangível, de valor organizacional, principalmente, o gerador de novos conhecimentos, o tácito. "Conhecimento não é dado nem informação [...] é uma mistura fluida de experiência condensada, valores, e insight ${ }^{11}$ experimentado [...] ele tem origem e é aplicado na mente dos conhecedores" (DAVENPORT; PRUSAK, 1999, p. 1, 6).

“Conhecimento tácito e explícito são, por vezes, difíceis de desatarem” (BECERRA; LUNNAN; HUEMER, 2008, p. 693). Isso pode ser visível quando organizações, a partir de conhecimentos tácitos, elaboram novas e produtivas formas de trabalho, as boas práticas, produto de uma fervilhante mistura de ideias, expertise (perícia), skills (habilidades), modelos mentais e outros conteúdos intangíveis.

Às boas práticas segue, implicitamente, um conhecimento complexo, tácito, que embora difícil de codizar, apresenta-se como essência na formulação de novos conhecimentos, práticas e rotinas organizacionais.

No Judiciário, não é diferente, busca-se adaptá-lo à sociedade do conhecimento ${ }^{12}$, a lidar melhor com as transformações impostas pelas novas demandas sociais e a oferecer melhor prestação jurisdicional, evitando a "inércia institucional” (REIS, 2001, p. 53).

Reconhece-se o valor do conhecimento explicitado. No entanto, ressalta ao pesquisador que está no conhecimento tácito o elemento inovador na construção de novos JEF. Por meio do compartilhamento de ideias e experiências é possível criar novo conhecimento que complemente e robusteça o já assimilado (BONACHE, 2010).

Nessa direção e dentro ainda do momento de análise da problemática, surgiram outras interrogações ainda iniciais (LAVILLE, 1999) que contribuíram para que ocorresse um aprofundamento de procedimentos teórico-metodológicos (GONDIM; LIMA, 2010).

Os questionamentos que afloraram, não necessariamente nessa ordem:

a) A titularidade de juiz em uma vara influencia o compartilhamento do conhecimento tácito?

\footnotetext{
${ }^{11}$ Insight é o resultado de um processo mental de análise de situações complexas ou problemas, caracterizando precisa e profunda compreensão dos mesmos (COLLINS, 1998).

${ }^{12}$ A sociedade do conhecimento será apresentada de forma mais detalhada no item 2.2.
} 
b) Os encontros de juízes podem estar associados a maior troca de conhecimento tácito?

c) Os juízes costumam partilhar conhecimento com seus subordinados?

d) Juízes substitutos costumam buscar conhecimento em juízes titulares ou vice-versa?

e) As boas ideias identificadas pelos juízes são compartilhadas com outros juízes?

f) O compartilhamento de conhecimento ocorre presencialmente, virtualmente ou de ambas as formas?

g) No campo de novos conhecimentos atrelados ao processo judicial ou dos entendimentos jurídicos, é comum o compartilhamento de conhecimento entre juízes e ASJ?

\subsubsection{O problema enunciado}

Como fruto da análise, percebe-se a necessidade de o Judiciário buscar "fórmulas" que o capacitem a enfrentar o novo contexto social. Seja pela mudança tecnológica, pela necessidade de dispor de pessoas com formação técnico-acadêmica diferenciada, pelo aumento da capacidade processante (dado o aumento de litígio provocado pelo enriquecimento de camadas antes desprivilegiadas economicamente), pelo acréscimo na entrada de ações judiciais, por ter-se transformado em um ator de boa resolutividade junto à sociedade, o fato é que carece o Poder Judiciário de melhor posicionar-se frente às críticas diariamente disparadas a ele.

Szulanski (1996, p. 27) coloca que “[...] o inexorável aumento de desempenho são necessários para manterem-se competitivas, as empresas [assim] devem cada vez mais recorrer à transferência interna de habilidades (know how)".

No processo de construção de um novo Judiciário, pode-se considerar a transferência do conhecimento tácito, elemento intangível e estratégico que "trata da conexão de pessoas com pessoas" (GIRARD; MCINTYRE, 2010, p. 72).

Arora (2011, p. 166), ao avaliar princípios da melhora do serviço público, aborda:

1) Conhecimento é criado na mente das pessoas;

2) Conhecimento pode ser capturado [...] ou simplesmente relembrado;

3) Conhecimento pode ser compartilhado.

Na Administração Pública Federal brasileira, Fresneda e Gonçalves (2007, p. 15) realçam

a capacidade [...] do setor público para desenvolver contextos e sistemas que apoiem

o compartilhamento e a criação e aplicação do conhecimento na área pública 
visando gerar benefícios para a sociedade, aumenta em importância e deve ser objeto de maior consideração.

Ao registrar a implementação da Diretoria Geral de GC, no Tribunal de Justiça do Estado do Rio de Janeiro (TJERJ), Gomes (2005, p. 23) salienta que "a GC é uma ferramenta capaz de contribuir decisivamente com o Poder Judiciário no esforço de prestar mais e melhores serviços".

Estas iniciativas parecem representar situações onde o conhecimento tácito não permanece adstrito a pessoas como silos independentes e em sua mobilidade ganha uso e valor. Salientam Nonaka e Konno (1998) que o conhecimento não usado no tempo e lugar específicos perde seu valor.

Se "nós sabemos mais do que nós podemos dizer" (POLANYI, 2009, p. 4), parte do conhecimento relacionado às tarefas organizacionais permanece como conhecimento tácito nas pessoas. Assim, a sua eficaz e efetiva utilização depende da mobilidade "concedida" a esse tipo de conhecimento. Hsu (2008) evidencia que há uma relação entre como as organizações incentivam e facilitam o compartilhamento de conhecimento e a melhoria do desempenho organizacional.

O trânsito do conhecimento tácito, a capacidade de o conhecimento fluir e a interação entre as pessoas, denominada por Nonaka e Takeuchi (1997) como socialização, demonstram a importância e a necessidade de prover mobilidade ao conhecimento.

Tal relevância é reforçada por (NONAKA; KONNO, 1998) que designam um espaço específico para o trânsito $-B A^{13}$ - que permite a ocorrência de relacionamentos e fundamenta a criação de novos conhecimentos. Sustentam os autores a importância de um foro ${ }^{14}$ onde o conhecimento seja compartilhado.

A literatura aponta outros comportamentos interativos semelhantes aos expressos por Nonaka (1994) em seu BA, como os tipos: "face-to-face environments" (GIRARD; MCINTYRE, 2010, p. 75), ou

- diálogo frequente e comunicação 'face a face';

- brainstorming, insights;

- trabalho tipo 'mestre-aprendiz';

- compartilhamento de experiências e modelos mentais via trabalho em equipe (SILVA, 2004, p. 145).

\footnotetext{
${ }^{13} \mathrm{Na}$ língua japonesa, o termo significa espaço.

14 Aqui usado no sentido de praça pública, do latim forum (SILVA, 2008, p. 636). O emprego do termo foi motivado ainda por se tratar, simultaneamente, de um trocadilho, pois no jargão judiciário o vocábulo significa também, "edifício onde funcionam os magistrados".
} 
A questão-problema que se apresentou, então, foi: quais variáveis, na ótica dos juízes, explicam o compartilhamento do conhecimento tácito, no âmbito dos JEF do Brasil?

A título de melhor compreensão das etapas da pesquisa, cabe aqui uma breve classificação das variáveis.

As variáveis interativas (VInt), hipotéticas (VH) e explicativas (VE) foram estabelecidas como variáveis independentes, ou seja, "variáveis selecionadas como previsoras e potenciais variáveis de explicação da variável dependente" (HAIR et. al., 2009, p. 154). A partir das VInt e das VH, construíram-se as hipóteses. As VE foram, dentre as VH, aquelas que explicaram o fenômeno.

A variável indicador $\left(\mathrm{i}_{\mathrm{CCT}}\right)^{15}$ é uma variável dependente, isto é, “a variável que está sendo prevista pelo conjunto de variáveis independentes" (idem). A variável é resultado da aplicação de técnicas estatísticas que serão apresentadas no decorrer do trabalho. Dessa forma, $\mathrm{i}_{\mathrm{CCT}}$ é dependente das VInt e VH.

O termo dimensões foi utilizado para englobar um determinado conjunto de variáveis e permitir a sua diferenciação, conforme uma categoria específica: pessoal, acadêmica, funcional, organizacional, geográfica e social.

\subsection{HIPÓTESE}

O teórico interessado pela verdade deve estar também interessado pela falsidade, porque descobrir que uma asserção é falsa é o mesmo que descobrir que sua negação é verdadeira. (POPPER, 1999, p. 24).

Por se tratar de uma pesquisa com ênfase descritivo-explicativa, a formulação da hipótese seguiu um suposto e provisório conjunto de variáveis que possam vir a impactar o fenômeno (GIL, 2010; MARCONI; LAKATOS, 2010).

Esse conjunto de variáveis é resultado do método aplicado ${ }^{16}$ que atende o objetivo específico 2, Mapear as possíveis variáveis associadas ao compartilhamento do conhecimento tácito entre os juízes do JEF e serviu de base às hipóteses que suportaram a formulação das perguntas do questionário, pois "rigorosamente, todo processo de coleta de dados depende da formulação prévia de uma hipótese”. (GIL, 2010, p. 23).

\footnotetext{
15 Indicador da propensão ao compartilhamento do conhecimento tácito.

${ }^{16}$ Capítulo Metodologia, item 3.4.3, Etapa 3 - Mapeamento das possíveis variáveis explicativas, estabelecimento das hipóteses e elaboração do instrumento de coleta de dados e informações.
} 
A hipótese foi dividida em duas partes. A primeira, nominada de hipótese central, traz o núcleo da suposição. A segunda apresenta uma ramificação dessa ideia, tratada na pesquisa por hipóteses derivadas.

\subsubsection{Hipótese central}

O compartilhamento do conhecimento tácito, nos JEF, entre o juiz, os seus pares, os agentes externos e a sua equipe de trabalho varia de acordo com as dimensões pessoal, acadêmica, funcional, organizacional, geográfica e social.

Essa hipótese central apresenta o personagem-eixo da investigação, o juiz federal lotado no JEF, do qual foram colhidas as percepções acerca do fenômeno do compartilhamento do conhecimento tácito.

Introduz também os elementos, julgados principais pelo autor, que compõem a sua rede de relações, estabelecida pela dinâmica do serviço e dentro da qual fluem as trocas de conhecimento e dão-se as interações pessoais.

Por fim, aponta um conjunto de dimensões que englobam e categorizam as variáveis hipotéticas (VH). Essas variáveis são conjecturas que foram aceitas pelo autor para explicar o compartilhamento do conhecimento tácito em ambiência de JEF, a serem verificadas sob a perspectiva dos juízes.

Embora essa hipótese central tenha trazido o fundamento para a condução da solução ao problema da pesquisa, verificou-se que as hipóteses derivadas especificaram ou decompuseram uma relação mais básica e generalizada (GRESSLER, 2003), puderam conferir melhores condições para a confirmação, refutação ou modificação das conjeturas traçadas (TURATO, 2010) e estão mais próximas das operações de teste e pesquisa (KERLINGER, 2003).

\subsubsection{Hipóteses derivadas (com base na $\mathrm{VH})^{17}$}

\section{1) Dentro da dimensão Pessoal}

a) variável 'gênero' (questão 1.2).

b) variável 'idade' (questão 1.4).

c) variável ‘naturalidade’ (questão 1.5).

\footnotetext{
${ }^{17}$ Entre os parênteses, encontra-se o número da pergunta do questionário. A apresentação de cada dimensão se dará no item 3.4.3.1, onde as hipóteses derivadas serão detalhadas.
} 


\section{2) Dentro da dimensão Acadêmica}
a) variável 'formação' (questão 1.6).
b) variável 'docência' (questão 1.7).
c) variável 'publicação' - questão 1.8).

\section{3) Dentro da dimensão Funcional}
a) variável 'tempo de $J F$ ' (questão 1.9).
b) variável 'titularidade' (questão 1.10).
c) variável 'tempo de JEF' (questão 1.11).

\section{4) Dentro da dimensão Organizacional}
a) variável 'lotação’ (questão 2.1).
b) variável 'número de varas/TR' (questão 2.2).
c) variável 'competência' (questão 2.1.1).

\section{5) Dentro da dimensão Geográfica}
a) variável 'Região' (questão 2.3).
b) variável ' $U F$ ' (questão 2.4).
c) variável 'Município' - questão 2.5).

\section{6) Dentro da dimensão Social}
a) variável 'participação presencial' (questão 3.4).
b) variável 'participação virtual' - questão 3.5).
c) variável 'rede social' (questão 3.6).
d) variável 'tecnologia particular' (questão 3.7).
e) variável 'critério para compartilhamento' (questão 3.9).
f) variável 'desenvolvimento organizacional' (questão 4.1).
g) variável 'imprescindibilidade’ (questão 4.2).
h) variável 'natureza do conhecimento' - questão 4.3).

\subsection{OBJETIVOS}

Os investimentos em conhecimento geram os melhores dividendos. (FRANKLIN, 1706-1790 apud BENJAMIN..., 2014, p. 1).

\subsubsection{Objetivo Geral}

Identificar as variáveis que explicam o compartilhamento do conhecimento tácito no âmbito dos Juizados Especiais Federais (JEF), consoante a perspectiva dos juízes. 


\subsubsection{Objetivos Específicos}

1) Analisar o processo de compartilhamento do conhecimento tácito segundo a literatura;

2) Mapear as possíveis variáveis associadas ao compartilhamento do conhecimento tácito entre os juízes do JEF;

3) Identificar as variáveis que explicam o fenômeno do compartilhamento do conhecimento tácito dentre as variáveis possíveis mapeadas.

\subsection{JUSTIFICATIVA}

Construímos muros demais e pontes de menos. (NEWTON, 1642-1726 apud ISAAC..., 2014, p. 1).

\subsubsection{A condição daquele que observa e vive o problema}

Não raras são as vezes em que aquele que observa e vive um fenômeno envida esforços para compreendê-lo melhor.

A motivação inicial encontrou raiz na frequência com que a temática de compartilhamento de conhecimento tem sido recorrente na execução dos trabalhos dos quais o autor participou como Analista Judiciário.

Tal vivência contribuiu para mapear as variáveis e elaborar as hipóteses. Como assinala Gil (2010, p. 20), "em boa parte dos casos a qualidade mais requerida do pesquisador é a experiência na área”.

A escolha dos JEF como campo da pesquisa deve-se, entre outras razões, por considerá-los especiais ${ }^{18}$, não somente por sua denominação, mas por ser um "novo modo de processar a demanda" (BRASIL, 2000, p. 9), torna-se "divisor de águas na história do Poder Judiciário brasileiro, alvo de críticas procedentes quanto ao seu desempenho, especialmente no que concerne à morosidade na entrega da prestação jurisdicional” (ANDRIGHI, 1997, p. 70).

Quando se verificou a oportunidade de realizar esta pesquisa, considerou-se ainda: a possibilidade de transformar observações e informações empíricas em um estudo científico; o fato de a pesquisa poder apresentar uma alternativa de gestão aos JEF; e ser o pesquisador,

\footnotetext{
${ }^{18}$ As especificidades do JEF serão apresentadas de forma mais detalhada no item 3.1.3.
} 
servidor do Judiciário federal, o que poderia trazer maior facilidade na aplicação do instrumento de coleta de dados, de informações e na obtenção das respostas.

\title{
1.5.2 A importância do compartilhamento do conhecimento tácito
}

As organizações são sociedades de mentes e as inteligentes aprendem e rejuvenescem por meio da incorporação das suas experiências. (CHOO, 2003, p. 15).

O conhecimento tácito, apesar de ser um bem incorpóreo, apresenta-se como um dos valiosos ativos intangíveis organizacionais (SVEIBY, 1997). Até 2007, sabia-se pouco sobre como o compartilhamento do conhecimento tácito ocorria e o que as organizações podiam fazer para tornar o processo bem sucedido (SMITH; MCKEEN; SINGH, 2007).

Esse fenômeno passou a ser objeto de muitos estudos, seja pelas mudanças que a sociedade com mais conhecimento infligiu aos indivíduos que buscaram compartilhar as suas ideias e conhecimentos (ASIAN PRODUCTIVITY ORGANIZATION, 2013), seja pela busca da transferência do conhecimento vital para o sucesso das organizações (DAVENPORT; PRUSAK, 1999). Korhonen (2014) assevera que o compartilhamento de conhecimento provê um mecanismo fundamental para o desenvolvimento da sabedoria organizacional.

No que diz respeito ao Judiciário, Martins, Fernandes e Pessanha (2005, p. 15) assinalam que

\begin{abstract}
A quantidade de conhecimentos produzidos cotidianamente no exercício da função jurisdicional é enorme (...) Assim, imagina-se que por meio da disseminação dos principais conteúdos [melhores práticas] (...) possa-se contribuir diretamente com o aumento da celeridade e da efetividade na prolação das decisões judiciais.
\end{abstract}

Muitos pesquisadores e profissionais comungam da mesma opinião e concordam que o compartilhamento tem sido o processo essencial na sociedade do conhecimento (NGAH; JUSOFF, 2009), e passou, em nível organizacional, a ser considerado como centro das atenções na gestão do conhecimento (KEGLOVITS, 2013).

Assinala Garvin (1998) que difundir o conhecimento com velocidade e eficiência pode ser uma boa prática, as novas ideias ganham força quando compartilhadas e isso inclui uma diversidade de canais, entre eles, os relatórios orais.

O espalhamento de conhecimento está associado a um ambiente de informalidade no relacionamento pessoal e no ambiente de trabalho (CROSS, 2007), embora Tonet e Paz (2006) advirtam que ainda não existe consenso sobre como ocorre o compartilhamento entre as pessoas. Smith (2001), contudo, apregoa que, independentemente da forma e do momento, a busca por conhecimento tácito é inexorável, atemporal e interminável. 
Para a Ciência da Informação essa responsabilidade de lidar com o compartilhamento é antiga.

Hoje, o problema da transferência do conhecimento para aqueles que dele necessitam é uma responsabilidade social e esta responsabilidade social parece ser o fundamento real da 'ciência da informação. (WERSIG; NEVELING, 1975, p. 28).

O compartilhamento também ganha destaque no processo da gestão de conhecimento (GC). No estudo de Oliveira (2014), onde vários modelos foram analisados, constatou-se que em todos o compartilhamento apresentava-se como um de seus principais processos.

Quadro 1 - Identificação do fenômeno de compartilhamento em modelos de GC

\begin{tabular}{|c|c|}
\hline Autores (ano) & Denominação do modelo \\
\hline Wiig (1993) & Modelo de GC \\
\hline Nonaka e Takeuchi (1997) & $\begin{array}{c}\text { Modelo genérico de criação do conhecimento } \\
\text { organizacional }\end{array}$ \\
\hline Davenport e Prusak (1999) & Modelo de GC \\
\hline Terra (2000) & Modelo sistêmico de sete dimensões da GC \\
\hline Stankosky e Baldanza (2001) & Modelo de GC de quatro pilares \\
\hline Stollenwerk (2001) & Modelo genérico de GC \\
\hline Teixeira Filho (2001) & Modelo de GC \\
\hline Bukowitz e Williams (2002) & Modelo de GC \\
\hline Choo e Bontis (2002) & Modelo de GC estratégico \\
\hline Probst, Raub e Romhardt (2002) & Modelo estratégico de GC \\
\hline Rossato (2003) & Modelo de implementação da GC \\
\hline Bennet e Bennet (2004) & Modelo de GC \\
\hline Dalkir (2005) &
\end{tabular}

Fonte: Oliveira (2014, p. 44).

Heisig (2009) ao estudar 160 modelos de GC destacou que dos 117 modelos que mencionaram 'atividades de GC', 96 citaram o compartilhamento ou termos de semelhante significado (transferência, distribuição). Isso mostra que $82 \%$ dos modelos que trataram das 'atividades de GC' citaram o compartilhamento como uma de suas fases estruturantes.

Korhonen (2014), ao assinalar que há muito mais de GC do que de tecnologia, salienta que esse "muito mais" pode ser composto por três subprocessos: (1) aprendizagem organizacional; (2) produção de conhecimento; e (3) distribuição do conhecimento. Bartol e Srivastava (2002) verteram o compartilhamento em componente chave dos sistemas de gestão do conhecimento.

Linde (2000, p.1) vai adiante e salienta uma forte razão para a existência do processo de GC; "na verdade, gestão do conhecimento é o ato de ajudar a estruturar a forma com que as pessoas compartilham o conhecimento". Comunga McDermott (2000) do mesmo pensamento, quando coloca que os maiores esforços na maioria dos programas de GC estão em proporcionar tempo às pessoas para articular e compartilhar as coisas realmente boas . Lahti e Moilanen (2004, p. 5) argumentam que "a essência da GC é valorizar os ativos 
intangíveis, tais como habilidades e competências". Essas considerações ratificam o foco dado à pesquisa ao estreitar a sua análise ao fenômeno do compartilhamento do conhecimento.

No que diz respeito ao conhecimento já materializado, o trabalho afasta-se da análise de compartilhamento de conhecimento explícito, isto é, de ativos de conhecimento tangíveis, já formatado em alguma mídia e dedica maior zelo aos processos de disseminação de conhecimento tácitos, intangíveis na visão de Wah (1999). Contudo, o compartilhamento é mais do que uma prática de gestão, "constitui um ato voluntário por parte daqueles que desejam compartilhar as habilidades e o know-how desenvolvidos no trabalho". (MCINERNEY, 2006, p. 59).

O quadro a seguir identifica algumas experiências onde se pôde notar a nominação de processos específicos para o compartilhamento de conhecimento tácito.

Quadro 2 - Identificação de processos relacionados ao compartilhamento de conhecimento tácito

\begin{tabular}{|c|c|c|}
\hline Autores (ano) & Denominação do modelo & $\begin{array}{l}\text { Nome do processo específico de } \\
\text { compartilhamento do conhecimento } \\
\text { tácito }\end{array}$ \\
\hline K4Health ${ }^{19}$ & $\begin{array}{l}\text { Modelo de GC para Saúde } \\
\text { Global }\end{array}$ & Compartilhamento de conhecimento \\
\hline $\begin{array}{c}\text { Nonaka e Takeuchi } \\
\text { (1997) }\end{array}$ & $\begin{array}{l}\text { Modelo genérico de criação do } \\
\text { conhecimento organizacional }\end{array}$ & Socialização \\
\hline $\begin{array}{c}\text { Davenport e Prusak } \\
\text { (1999) }\end{array}$ & Modelo de GC & $\begin{array}{l}\text { Transferência espontânea e não } \\
\text { estruturada }\end{array}$ \\
\hline Grotto (2001) & Modelo de GC & Compartilhamento \\
\hline Van den Brink (2003) & Modelo de compartilhamento & $\begin{array}{l}\text { Compartilhamento tácito-tácito } \\
\text { (diálogo) }\end{array}$ \\
\hline $\begin{array}{c}\text { Asian Productivity } \\
\text { Organization }(2013)^{20}\end{array}$ & APO GC framework & Compartilhar \\
\hline
\end{tabular}

Fonte: Do autor.

\subsubsection{Inexistência de estudo sobre compartilhamento de conhecimento tácito no judiciário}

As organizações devem aprender com suas experiências e compartilhar esse conhecimento internamente. (MIRANDA; MORESI, 2010, p. 410).

O Congresso Nacional dos Juizados Especiais Federais (2003), promovido pelo Centro de Estudos Judiciários do Conselho da Justiça Federal, nos dias 20 a 22 de outubro de 2003,

${ }^{19}$ K4Health é uma entidade internacional que trabalha para melhorar acesso e compartilhar conhecimento em saúde pública em determinados países, regiões e de forma global, particularmente sobre reprodução e planejamento familiar. Inclui ainda tópicos relacionados à HIV/AIDS e saúde materno-infantil (K4HEALTH, 2015).

${ }^{20}$ Asian Productivity Organization é uma organização intergovernamental cuja missão é contribuir para o desenvolvimento socioeconômico sustentável da Ásia e Pacífico através do aumento da produtividade. 
reuniu juízes das cinco regiões da Justiça Federal e apresentou a situação dos Juizados Especiais Federais - JEFs, com base no relato das experiências vivenciadas pelos próprios juízes. Como Procedimentos para os Juizados Especiais Federais - Soluções viáveis/sugestões e críticas, citou-se a de viabilizar a troca de conhecimento entre Juizados (CONGRESSO NACIONAL DOS JUIZADOS ESPECIAIS FEDERAIS, 2003). Mas de fato isso ocorre? Que variáveis poderiam explicar tal troca?

Assinalam Lahti e Moilanen (2004) que, apesar da importância do conhecimento tácito e do seu compartilhamento, as organizações não têm frequentemente incluído esses temas em suas ações cotidianas. Dos estudos acerca do compartilhamento detectados por ocasião da revisão da literatura, poucos tiveram o Judiciário ou parte dele como área de trabalho.

A GC no judiciário brasileiro carece de uma interpretação própria e elaboração de uma estratégia específica que aborde, "além da gestão procedimental, um efetivo acesso ao conhecimento institucional (existente ou por descobrir) e seu reaproveitamento e aprendizagem" (RUSCHEL, 2012, p. 91).

\subsubsection{Interesse dos juízes pela aplicação da pesquisa}

Parece ainda interessante apresentar um dado quanto ao interesse dos juízes em conhecer os resultados da pesquisa nos JEF. Dos 95 respondentes ao questionário, 71 mostraram-se interessados, conforme o quadro abaixo.

Tabela 1 - Número de juízes interessados em conhecer os resultados da pesquisa*

\begin{tabular}{r|c}
\hline INTERESSE & TOTAL \\
\hline Sim & 71 \\
Não & 24 \\
\hline
\end{tabular}

Fonte: Do autor.

Nota: * A pergunta do questionário: Q1 Caso tenha interesse em conhecer os resultados desta pesquisa, por favor, assinale a opção abaixo:

Esse quadro vai ao encontro da proposição de Gomes (2005, p. 12) quando analisa o compartilhamento dentro do processo de GC do Tribunal de Justiça no Estado do Rio de Janeiro (TJ-RJ), o "compartilhamento é a palavra de ordem. Devemos então estimular a cultura do compartilhamento".

O interesse demonstrado pelos juízes parece ter sido confirmado por suas declarações ${ }^{21}$, ratificando o caráter de relevância da pesquisa.

As trocas de informações e experiências são quase exclusivamente referentes a mecanismos de auxiliem na gestão da Vara de Juizado, tornando a tramitação dos processos mais célere, sem comprometer as garantias fundamentais do processo.

\footnotetext{
${ }^{21}$ Os depoimentos citados deram-se no campo “considerações livres” do questionário.
} 
Apesar de o contato com os colegas não ser tão diversificado, reputo que o meu conhecimento é público em virtude dos fundamentos que sempre são explicitados nas decisões/sentenças prolatadas. A troca de experiências não é maior muitas vezes pelo excesso de trabalho que impede de participar de mais eventos como Fóruns Nacionais ou Regionais (Juiz 3).

A troca de experiências é vital em todos os níveis de conhecimento (juiz 14).

A mobilidade do conhecimento tácito é necessária para a eficácia e excelência da prestação jurisdicional. Contudo, com a carga de trabalho no JEF, fica difícil para o juiz federal conciliar a necessidade da extensão da mobilidade do aludido conhecimento com a necessidade da efetiva e rápida jurisdição. De fato, precisamos compartilhar mais conhecimento. No entanto, isso demanda tempo, o qual é escasso (juiz 17).

Penso que são muito escassas as oportunidades propiciadas institucionalmente pela Justiça Federal da $4^{\mathrm{a}}$ região para a efetiva troca de experiências entre os magistrados. No mais das vezes são oferecidos eventos por intermédio da escola da magistratura nos quais a participação dos juízes é passiva (como ouvintes). Lembro que quando ingressei na carreira em 1994 havia uma prática muito interessante e proveitosa instituída pelo tribunal, que consistia na realização sistemática de workshops, sempre com a participação de um juiz do tribunal, e onde o foco era a discussão sobre as questões emergentes ligadas diretamente ao trabalho dos juízes. Assim os juízes tinham contato direto com o pensamento do tribunal sobre determinado tema e podiam debatê-lo diretamente. Infelizmente essa prática foi abandonada e, a partir da institucionalização da escola da magistratura, passaram os juízes a meros ouvintes em cursos de aperfeiçoamento, cujo principal atrativo reside no fato de que esses cursos pesam na hora das promoções por merecimento. No plano pessoal, as eventuais iniciativas para a troca de conhecimentos resumem-se aos interlocutores mais próximos - quer fisicamente quer por algum interesse comum (como no caso da docência). Acredito que a organização perde muito com a ausência de um modelo sistematizado que fomente a troca de conhecimento de forma ampla e eficiente (juiz 19).

A iniciativa da pesquisa é salutar. A interação de conhecimentos, na quadra atual, se afigura cada vez mais inevitável, com perspectivas alvissareiras (Juiz 21).

Para atingir os objetivos traçados, o trabalho foi estruturado, além deste de cunho introdutório, em quatro capítulos. O segundo, apresentou a revisão de literatura com abordagem de diversos autores que emprestaram as suas observações para apoiar a discussão acerca do tema, o conhecimento, e do objeto, o fenômeno do compartilhamento do conhecimento tácito.

Os procedimentos metodológicos, incluindo o ambiente da pesquisa, a população e a amostra, a classificação da pesquisa e o método específico para identificar as variáveis explicativas do fenômeno, compuseram o terceiro capítulo.

O quarto capítulo trouxe os resultados, evidenciando as características dos sujeitos amostrais e as respostas da aplicação do método sobre os juízes federais dos JEF, apontando as oito variáveis explicativas do fenômeno.

Finalizando o estudo, o quinto capítulo apontou, além das conclusões, as limitações da pesquisa e algumas propostas de trabalhos futuros. 


\section{REVISÃO DA LITERATURA}

O fenômeno do conhecimento humano é, sem dúvida, o maior milagre de nosso universo. (POPPER, 1999, p. 7).

O termo conhecimento pode servir para nominar o ato de conhecer, "enquanto relação que se estabelece entre a consciência que conhece e o mundo conhecido" (ARANHA, 1993).

Para Davenport e Prusak (1999), o conhecimento integra valores, contexto e insight, no qual se estruturam novas experiências. É intangível, dinâmico e não obedece fronteiras (NONAKA; KONNO, 1998).

O conhecimento para Wilson (2002) compreende o processo mental de compreensão, entendimento e aprendizagem que se desenvolve na mente humana e envolve interação com o mundo externo (à mente) e com outros.

O conhecimento também é um ativo que possibilita a geração de riqueza, e aumenta quando compartilhado (AFONSO; CALADO, 2011). É resultado de interações que caracterizam o ambiente organizacional como experiências sociais (CHOO, 2003), reforça a prática de aprendizagem (FLEURY; OLIVEIRA JR., 2001) e é "considerado essencial tanto do ponto de vista acadêmico quanto profissional" (TOMAÉL; ALCARÁ; DI CHIARA, 2005, p. 93).

Na tarefa de resolver um problema, inicialmente, lança-se mão de um conhecimento 'escondido', ou que ainda não foi transformado em algo tangível, como relatórios, manuais, conteúdos de sistemas de comunicação. Polanyi (2009) trata esse conhecimento dentro de uma dimensão tácita, ou seja, um conhecimento que ainda está implícito, não expressado, que inclui as ideias, as experiências, as habilidades. Nonaka e Takeuchi (1997), igualmente, traduzem-no como conhecimento tácito e como origem na criação de todo conhecimento organizacional. Sveiby (1997) descreve-o como uma parcela significativa daquilo que é ou encontra-se ainda na forma tácita, dinâmica, e que se torna estático quando explicitado. Esse conhecimento tácito, embora incorporado em repositório mental individual, pode ser socialmente compartilhado (LOENHOFF, 2015) e como conhecimento 'coletivo' é codeterminado por estruturas sociais (KALDEWEY, 2015).

O termo informação, quando utilizado, refere-se ao conhecimento que já foi explicitado, retirado da mente do indivíduo, e encontra-se materializado em qualquer meio (pedra, papel, plástico, eletrônico), estabelecido em qualquer mídia (rádio, televisão, 
imprensa, publicação, adesivo, foto, filme, Internet e seus conteúdos, whatsapp, twiter, homepage, blog).

O objetivo das seções seguintes é o de apresentar algumas teorias que antecederam a discussão que se faz hoje sobre a importância do conhecimento tácito e de seu compartilhamento nas organizações.

\subsection{A TEORIA DO CRESCIMENTO, A VISÃO BASEADA EM RECURSOS (VBR) E O APARECIMENTO DA TEORIA BASEADA EM CONHECIMENTO.}

Penrose $(2006)^{22}$ ao realizar análises das empresas nos anos 1950, buscava descobrir se havia algo que pudesse diferenciar organizações quanto ao seu crescimento. Detectou que a experiência dos administradores traduzida pelo seu conhecimento revelava-se como o fator diferenciador de uma organização para outra e assinalou que esse conhecimento não podia ser adquirido no mercado.

Essa experiência encontrava-se transformada em conhecimento tácito e não estava disponível de forma manualizada ou codificada, ou seja, explícita, para ser materialmente incorporada pela organização. Segundo a autora, tais profissionais poderiam estimular ou limitar o avanço da empresa.

Questionou também em seu estudo sobre o crescimento da firma a possibilidade de haver algo na organização além da visão tradicional de manuseio de recursos humanos (mão de obra) e produtos (cadeia produtiva). Entre várias razões para sustentar a sua teoria, Penrose (2006) apontou um recurso em especial que poderia estar associado ao crescimento das firmas, o conhecimento, especialmente o individual, posteriormente tratado por tácito (POLANYI, 2009; NONAKA; TAKEUCHI, 1997).

Penrose (2006, p. 16) desenvolveu como um dos pressupostos fundamentais dessa teoria o de que o crescimento da organização "é essencialmente um processo evolucionário e está baseado no incremento cumulativo do saber coletivo". Algo que Inkpen (1996) tratou por 'conhecimento colaborativo' e Nonaka e Takeuchi (1997) viriam a representar depois pela 'espiral' do conhecimento epistemológico e ontológico.

$\mathrm{O}$ argumento central da teoria, então, indica que a taxa de crescimento de uma empresa guarda estreita relação com o volume de conhecimento nela estocado, constituindose mais do que uma unidade administrativa, um conjunto de conhecimentos produtivos. Por outro lado, aponta Penrose (2006) prejuízos consideráveis, comparáveis à perda de capital,

${ }^{22}$ O trabalho original data de 1959. 
quando experientes empregados abandonam seus postos ou quando seus ativos intelectuais são dispersos na organização por motivo de mudança de administração.

Ao discutir a natureza do conhecimento, a autora apresenta-os sob duas formas de compartilhamento, ambas provenientes de um processo de aprendizagem entre pessoas: a do compartilhamento do conhecimento ensinável e a do compartilhamento do conhecimento apreendido a partir da experiência. A primeira dá-se principalmente quando o conhecimento é trocado e o destinatário, desde então, sente-se apto a utilizar o conhecimento recebido. $\mathrm{O}$ segundo acontece quando o destinatário experimenta o novo conhecimento e acumula-o com base nessa vivência, isto é, na sua própria experiência.

No entanto, destaca que o crescimento do conhecimento está relacionado com a obtenção e utilização, sendo que "em considerável medida, a capacidade de usar antigos conhecimentos depende da aquisição de novos" (PENROSE, 2006, p. 101) o que parece indicar a imprescindibilidade de um processo de compartilhamento.

Inkpen (1996) ao discorrer sobre novos conhecimentos, colocou que a sua criação, cada vez mais, estava se tornando uma prioridade gerencial e que novos conhecimentos proveem a base da renovação e sustentabilidade da vantagem competitiva. Acrescenta que o fracasso na criação e no compartilhamento do conhecimento como um ativo crítico pode contribuir para um declínio de desempenho organizacional.

$\mathrm{Na}$ análise mais detida sobre recurso (humano) e conhecimento, destaca Penrose (2006) que os serviços prestados pela empresa dependem da capacidade das pessoas em lidar com o conhecimento que compartilham, enviando ou recebendo. Assinala que assim como o conhecimento molda o recurso (humano), este, por sua vez, 'devolve' à empresa um novo conhecimento já alterado pela sua própria capacidade intelectiva. Assim, o indivíduo $1\left(\mathrm{I}^{1}\right)$ recebe o conhecimento A e compartilha com o indivíduo $2\left(\mathrm{I}^{2}\right)$. Este por sua vez modifica o conhecimento A com base em seu estoque e compartilha o conhecimento A-modificado (A+). Se um indivíduo $3\left(\mathrm{I}^{3}\right)$ recebe $\mathrm{A}+$, já o compartilha com um conhecimento agregado, A++.

No início da década de 1990, dentro do campo da gestão estratégica amalgamada com a economia firma-se a teoria "Visão Baseada em Recurso (VBR) ${ }^{23}$ tendo o trabalho de Penrose (2006) como uma notável contribuição (PETERAF, 1993). Para Bierly, Kessler e

\footnotetext{
${ }^{23}$ Conhecida na literatura em inglês por 'Resource-Based View'.
} 
Christensen (2000) tal teoria quase suplantou a tradicional visão relacionada a organizações industriais (I/O approach $^{24}$ ) tratada por Porter dez anos antes (PORTER, 1980).

Essa teoria associa o desempenho da organização à conjugação de dois elementos, Recursos e Capacidades $(R \& C)^{25}$, neles se destacam as habilidades e competências em lidar com o conhecimento, demonstrando já um interesse inicial pelo conhecimento tácito. A teoria busca explicar e predizer porque algumas organizações são capazes de sustentar uma vantagem competitiva e obter melhores retornos financeiros.

Segundo a teoria, o recurso (knowhow) pode ser convertido em capital humano e vir a compor ou gerar algum tipo de serviço ou tornar-se um ativo organizacional tangível ou intangível, considerado como o mais importante recurso estratégico (ZACK, 2011).

A capacidade traz consigo a habilidade em saber dispor desses recursos em processos organizacionais tangíveis e intangíveis e baseia-se em compartilhar conhecimento através do capital humano (AMIT; SCHOEMAKER, 1993), o que tratava Itami (1987) por 'ativos invisíveis' dentro de uma concepção de capacidade baseada em conhecimento ${ }^{26}$. Zack (2011) atribui à habilidade de criar e aplicar o conhecimento como a mais importante das capacidades para se construir e sustentar uma vantagem competitiva. Para Korhonen (2014), o valor dessa capacidade reside no conhecimento tácito das pessoas que compõem a organização.

Grant (2011), ao analisar a teoria relacionada aos $R \& C$, apresentou quatro características que provavelmente seriam particularmente determinantes para sustentar uma vantagem competitiva. Tidas inicialmente como empecilhos às empresas por sua própria condição de sobrevivência no mercado, a análise na pesquisa, contudo, examinou a essência de cada característica e de como poderiam ser observadas segundo uma ótica de organismos públicos. Assim, ao final de cada descrição da característica, foi inserida uma consideração quanto ao ambiente da pesquisa nos JEF.

1) Durabilidade - $R \& C$ depreciam-se com o tempo e tornam-se obsoletos. Uma alternativa para essa situação é a manutenção de um parque tecnológico atualizado com o ritmo das mudanças do ambiente. Outra, é o giro de capital humano, com

\footnotetext{
${ }^{24}$ A abordagem (I) Industrial/(O) Organizacional refere-se a um modelo de negócio apreciado por Porter em sua obra Estratégia Competitiva, onde, para se garantir uma bom desempenho, a organização deveria assemelhar-se à estrutura de uma indústria, utilizando uma das seguintes estratégias: liderança por custo (vender barato); liderança por diferenciação (fazer algo diferente); ou liderança por foco (concentra-se em atender específicos segmentos e mercado). Tempos depois, Porter (1989), por meio de outro trabalho Vantagem Competitiva, analisa a introdução de conceitos já sinalizados pela VBR, como a importância das habilidades internas e as competências humanas como fatores críticos para o bom desempenhar das atividades essenciais da organização.

${ }^{25}$ A literatura traz o binômio como 'Resources \& Capabilities'.

${ }^{26}$ No inglês, 'knowledge-based view'.
} 
novas contratações. A terceira, tida como um dos mais importantes papéis da cultura organizacional, para manter $R \& C$ sustentáveis e competitivos, é a socialização de conhecimento entre os empregados.

Essa ótica, associada aos estudos de Nonaka e Takeuchi (1997), mostrou-se importante, no sentido de se verificar que variáveis explicaram a socialização do conhecimento tácito no ambiente dos JEF.

2) Transparência - característica relacionada com a identificação na organização vizinha dos recursos necessários para se obter o grau de capacidade desejado. Em outras palavras: se a organização A deseja alcançar um padrão $R \& C$ semelhante ao da organização $\mathrm{B}$, ela deve conhecer seu próprio $R \& C$ e verificar em quais recursos ela deve melhorar a fim de atingir um grau de desempenho apresentado pela outra organização. O parâmetro de comparação serão os $R \& C$ de uma e de outra. Quando esse equilíbrio é possível entre as organizações, isto é, quando ocorre a transparência necessária para contribuição mútua, o compartilhamento de conhecimento apresenta-se como um dos modos de se buscar esse equilíbrio.

3) 'Transferibilidade ${ }^{27}$ - característica resultante da forma como a organização lida com os seguintes fatores:

a) Geográfico - buscar um padrão $R \& C$ superior pode requerer uma realocação de equipamentos e empregados especializados, o que gera uma movimentação expressiva de recursos caso haja uma grande dispersão da organização em níveis regional, nacional ou internacional;

b) Heterogeneidade de conhecimento - a habilidade de lidar, particularmente com o conhecimento embutido no ser humano (o tácito), e perceber como ocorre a movimentação e integração desse conhecimento nas equipes e nas rotinas de trabalho (a troca entre quem sabe mais e quem sabe menos) podem trazer ganhos à produtividade;

c) Especificidade dos recursos - quanto mais específicos são os recursos empregados em determinada organização, em especial o conhecimento, mais difícil fica o seu emprego em outro tipo de organização e dessa forma a sua transferência.

d) Capacidades - entendida como a habilidade em lidar com os recursos, quase sempre a capacidade está associada a times, equipes de trabalho e assim, não se

27 Os diversos aspectos da 'transferibilidade' contribuíram para a inserção de algumas hipóteses e foram associados aos questionamentos pertencentes ao instrumento de coleta de dados e informações. 
trata mais de transferir um conhecimento individual, mas um conhecimento coletivo atrelado a uma rotina, um processo de trabalho.

4) Replicabilidade - tal característica reflete a facilidade ou não em se replicar R\&C. Alguns conhecimentos e capacidades podem estar associados a complexas rotinas organizacionais e por isso menos facilmente replicáveis. Tais rotinas complexas envolvem menos conhecimento explícito (já codificado fora das mentes, em manuais, sistemas, etc.) e mais conhecimento tácito que se funde à respectiva cultura da organização.

Grant (2011), ao considerar o conhecimento tácito como um elemento importante para a replicabilidade, fortaleceu os propósitos da pesquisa de verificar quais variáveis influenciavam na movimentação desses ativos intangíveis.

No âmbito dos JEF, juízes, Varas e Regiões que demonstrarem maior grau de compartilhamento, podem estar mais aptos a replicarem rotinas (boas práticas), caso haja essa necessidade.

Considerando o conhecimento como um recurso utilizável para aprimorar a eficiência e a eficácia organizacional (BARNEY, 1991), a VBR surge como precursora de uma nova teoria, a 'visão baseada em conhecimento (VBC)', onde este ativo, o conhecimento, é tido como o mais estrategicamente importante dos recursos da empresa (GRANT, 1996) e a organização, como sendo um veículo de criação, compartilhamento, armazenamento e aplicação desse recurso (ZACK, 2011).

As questões abrangidas pela VBC, todavia, vão além de sua origem como recurso ímpar de uma gestão estratégica. Abarcam áreas importantes do modus operandi organizacional, como, "a coordenação das rotinas de trabalho, as estruturas organizacionais, os papéis dos gestores nos processos de decisão e inovação" (GRANT, 1996, p. 110).

Salienta Zack (2011) a relevância dos conhecimentos tácito e coletivo cuja origem está nas experiências práticas, internalizados nas rotinas e na memória dos membros da organização. Kogut e Zander (1993), a partir da VBC, associam o crescimento da organização ao compartilhamento do conhecimento.

A determinação precisa de como as organizações vão reagir a tal fenômeno do compartilhamento vai, no entanto, depender de seu próprio posicionamento frente ao que se tem chamado de sociedade ou era do conhecimento. 


\subsection{A SOCIEDADE DO CONHECIMENTO}

Viveu o Judiciário (e ainda vive) o seu momento de 'crise', [...] a chamada 'crise do Poder Judiciário' [...] O incremento da atividade judicial [trazido pelas novas demandas] encontrou o sistema judiciário pouco ou rudimentarmente aparelhado para enfrentá-lo, apresentando cultura organizacional, instrumentos e procedimentos ultrapassados e muitas vezes, inadequados. (SIFUENTES, 2006, p. 63).

Parece ser mais fidedigno nominar a sociedade atual, menos como sociedade da informação e mais como sociedade (ou era) do conhecimento (LASTRES; ALBAGLI, 1999; ALVARENGA NETO, 2007). Sustenta-se que uma transição está em andamento para uma economia e sociedade baseadas em conhecimento (QUÉRÉ, 2003).

A aparição e o emprego intenso de novas tecnologias digitais determinaram novas e importantes engrenagens para o desenvolvimento político e social de nações e indivíduos (BALBONI et. al., 2009). Caminha assim a sociedade na direção de um aumento de suas atividades baseadas em conhecimento, onde a organização e compartilhamento de ideias ocorrem simultaneamente (ASIAN PRODUCTIVITY ORGANIZATION, 2013).

O modo de filtrar as relações sociais de compartilhamento de conhecimento segue também tal tendência. $\mathrm{O}$ ambiente organizacional público judiciário, dentro do contexto dessa nova sociedade, não difere dos ambientes privados. Em ambos, o desenvolvimento das relações sociais (movimento relacional), entre outros pontos, predetermina a disposição de transferência do conhecimento. Com o aumento da interconectividade e com a necessidade de rápidas mudanças as pessoas e organizações foram obrigadas a compartilhar o que sabem e aprender uns com os outros (SMITH; MCKEEN; SINGH, 2007).

Esse trânsito acaba por provocar um intercâmbio de ativos imateriais, o conhecimento, entre pessoas e organizações, o que Van Caenegem (2005, p. 285) trata por "mercado de intangíveis" que, apesar de relevante, ainda não encontrou o devido espaço nos JEF.

$\mathrm{Na}$ socialização intercambiante de conhecimento oferecem-se novas ideias e criam-se bases para o desenvolvimento de novos produtos e serviços com a possibilidade de implantação de mecanismos $\left(\operatorname{rotinas}^{28}\right.$ ) inovadores. As rotinas e fluxos laborais estão inerentes às interações humanas e podem trazer mudanças positivas.

Assinalam Casselman e Samson (2011) que o emprego do conhecimento tácito guarda significativa relação com produtos inovadores e desempenho financeiro. Gomes (2005) ao estudar o Judiciário fluminense colocou ser o conhecimento o principal ativo da chamada sociedade do conhecimento.

\footnotetext{
${ }^{28}$ Emprega-se o termo "rotina" em lugar de "processo", com o fim de não trazer confusão com processo judicial (ação, auto judicial).
} 
Novos conhecimentos e o seu compartilhamento redefinem problemas e soluções e dão novo corpo a organização e ao meio circundante. As trocas alteram o volume de conhecimento prévio e aumentam a permeabilidade do tecido institucional, permitindo movimentos de conhecimento de dentro para fora e vice-versa, seja provocando intercâmbio individual, setorial, organizacional ou interorganizacional (NONAKA; TAKEUCHI, 1997).

Apresenta-se a nova era como um descolamento da ênfase nos fluxos de informação tangível e prepara uma nova visão de mundo onde singularidade, flexibilidade e desempenho, redirijam as organizações para um mercado cada vez mais relacionado e próximo do intangível (PIRES, 2012).

O momento atual impõe uma gestão segundo um fluxo de conhecimento decorrente de uma nova atmosfera criada e desenvolvida pelas organizações de modo a possibilitar a recuperação e emprego desse conhecimento, especialmente o conhecimento pessoal, mais efetivo (CROSS, 2007), favorável à emergência do novo e da inovação (ALVARENGA NETO, 2007; ALVARES, 2010).

Estudos realizados em seis organizações do setor público asiático (ASIAN PRODUCTIVITY ORGANIZATION, 2013) mostraram a preocupação por uma melhor compreensão do manuseio do conhecimento. Fizeram a escolha por se aumentar a eficiência segundo o conhecimento dos mais experientes, visando melhorar a excelência operacional e estratégica.

A nova abordagem requereu rediscutirem como o conhecimento individual e organizacional estava (ou não) sendo criado e compartilhado, pois os entenderam como fases fundamentais de qualquer processo que pretenda lidar com mudança de mentalidade e comportamento.

No trabalho conduzido por Girard e McIntyre (2010), no Departamento de Defesa Nacional do Canadá, apesar de entenderem esse processo de gestão como algo que não é novo, destacaram a importância de tratá-lo como um modelo no qual a socialização do conhecimento tácito ganha expressão de processo. Ressaltaram, ainda, como vultoso resultado, o fato de o compartilhamento de conhecimento gerar elevado grau de cooperação e aprendizado, algo semelhante ao que Kerckhove (1999) trata por inteligência conectada.

Gomes (2005), ao avaliar o compartilhamento do conhecimento no Judiciário fluminense, como Girard e McIntyre (2010), citou o modelo de criação e compartilhamento de Nonaka e Takeuchi (1997) a ser visto adiante. Tal alusão dá-se em decorrência desse 
modelo tratar da socialização do conhecimento tácito e de experiências como pontos de destaque.

O trabalho no Tribunal de Justiça do Estado do Rio de Janeiro revela ainda uma fala do presidente do Serpro, onde ressalta que os avanços conseguidos pela empresa devem-se, em grande parte, à decisão de manusear o conhecimento como um ativo estratégico. Conclui, salientando que tal capacidade de gestão contribui decisivamente para o Poder Judiciário prestar melhores serviços.

Pesquisadores da organização "Conhecimento para a Saúde Global” (K4HEALTH, 2015), um dos modelos de Gestão do Conhecimento a serem apresentados na seção seguinte, seguem a mesma direção, ao apontar a criação e o compartilhamento como elementos de relevo da gestão, principalmente no que diz respeito ao emprego de informação e experiências $^{29}$.

Embora iniciativas de geração de novos conhecimentos não se mostrem frequentes, mesmo sabendo que o desempenho organizacional requeira a geração de novas ideias (COUTINHO et al., 2008), parece que algumas organizações vêm buscando utilizar o conhecimento criado e compartilhado para aumentar a produtividade, para enfrentar novos desafios e para desenvolver práticas inovadoras na melhoria da qualidade dos processos (BATISTA, 2012).

Para o reposicionamento ou adaptação do Judiciário à sociedade do conhecimento, são requeridas mudanças que determinam transformações, às vezes, radicais, no que diz respeito ao emprego intensivo do conhecimento nos processos de trabalho (TARAPANOFF, 2006).

Assim, os elementos constitutivos da nova realidade exigem do Judiciário um posicionamento distinto dos até aqui empregados. Neste ponto, a Ciência da Informação que lida com transmissão do conhecimento humano (BATES, 1999), por meio de um olhar diferenciado, incita o pesquisador a verificar que variáveis estão associadas ao compartilhamento do conhecimento tácito.

Se conhecidas tais variáveis, passa a ser possível um tipo de gestão capaz de aprimorar o fluxo de conhecimento, trazer inovação ao julgamento das ações, aperfeiçoar a administração judicial e reduzir os efeitos da crise aqui mencionada.

${ }^{29}$ K4Health é uma entidade internacional que trabalha para melhorar acesso e compartilhar conhecimento em saúde pública em determinados países, regiões e de forma global, particularmente sobre reprodução e planejamento familiar. Inclui ainda tópicos relacionados à HIV/AIDS e saúde materno-infantil. (K4HEALTH, 2015). 
A Justiça Federal tem trabalhado com muitos dados e informações. Esses elementos habitam os sistemas de informação e os relatórios e podem, sem muito esforço, serem recuperados. A era do conhecimento, todavia, sugere às organizações, incluindo as públicas, a criação de novos caminhos para o melhor emprego do conhecimento, especialmente o tácito.

Este século, mais que outros, tem compelido as organizações a associarem sua estrutura interna e seus processos de trabalho a um novo ativo, de natureza intangível, o conhecimento (JELENIC, 2011). A Justiça Federal do Brasil é uma dessas organizações.

A provocação para que a pesquisa seguisse o rumo que seguiu parte da observação do comportamento de alguns juízes durante encontros presenciais frente a esse novo ambiente. Foi percebido que enquanto um grupo de juízes compartilhavam ideias inovadoras e boas práticas, outros permaneciam como observadores curiosos e um tanto quanto distantes daquela nova realidade. Para alguns, as soluções tão desejadas ainda não haviam sido inventadas. Para outros, inovação e conhecimento pareciam fazer parte de suas rotinas. Deduziu-se naquele momento que, mesmo em crise, o corpo de juízes aparentemente não se engajava em compartilhamento de conhecimento. Pareceu que mesmo cercados de informação, careciam de conhecimento (PETERS, 1989; HAIR, et al., 2009). Contudo, o que vem a ser o conhecimento tácito e como se dá o seu compartilhamento?

\subsection{O CONHECIMENTO TÁCITO E O SEU COMPARTILHAMENTO}

Inacreditavelmente há juízes que não tem a prática de realizar reuniões com seus servidores. Existem servidores com considerável tempo de serviço que nunca foram convidados para participar com o juiz de uma reunião de trabalho (VIEIRA, 2009, p. $105)$.

O conhecimento tácito, ou aquilo que se acumula na mente do indivíduo sob a forma de ideias e experiências (LEITE, 2007), encontra-se em pauta, de alguma forma, nos últimos quarenta anos (KRISHNAVENI; SUJATHA, 2012). Apresenta-se como um conhecimento que foge à formalidade e à materialidade, por isso, não capturado em licenças e patentes (KNOCKAERT et al., 2011). Torna-se um atributo daqueles que sabem o que estão fazendo e melhor compreendem as necessidades a serem supridas, como um hábil artesão cujo conhecimento está altamente personalizado e profundamente enraizado em suas experiências, valores e emoções (KORHONEN, 2014).

É de essência altamente pessoal (NONAKA; KONNO, 1998; OLIVEIRA, 2000; MAIA, 2011), melhor compartilhado por meio de conversação (GOH, 2002) e com fluidez mais acentuada em ambientes de natureza informal (OLIVEIRA, 2005). 
Alavi e Leidner (2001) compreendem-no como algo enraizado nas ações e experiências dos indivíduos e o categorizam como cognitivo (mapas mentais, crenças, paradigmas e pontos de vista) e técnico (know-how, habilidades). Outros, tratam o conhecimento tácito como "coisas que proveem do cérebro de alguém: programação eletrônica, marca de fábrica e força de marketing" (EDVINSSON; MALONE, 1999, p. 12). Lemos e Jóia (2008) traduzem-no como resultado direto de experiências, reflexões e diálogo.

A maior parte do conhecimento organizacional é tácito e inclui intuição, perspectivas, crenças e valores (SAINT-ONGE, 2011). É estimado em $80 \%$ do conhecimento útil de uma organização (CARVALHO; MASCARENHAS; OLIVEIRA, 2006) e quando não compartilhado traz mais problemas ou dificuldades do que resultados úteis (POLANYI, 2009).

Embora pareça uma questão menor para alguns gestores, ressalta-se que todo o conhecimento prático é, em quase toda a sua extensão, tácito (SVEIBY, 1997) cuja aplicação mais comum é resolver problemas (KORHONEN, 2014). Segundo Martins, Fernandes e Pessanha (2005), esses 'saberes tácitos' ficam espalhados pela organização e advém do exercício prático profissional.

O conhecimento tácito é dinâmico, não quantitativo e inerente à prática e ao know-how das pessoas (STAPLETON; SMITH; MURPHY, 2005). Como marca do conhecimento organizacional, é algo criado dentro de uma complexa interação entre pessoas (PATOKORPI, 2006).

Esse ativo intangível cuja origem está diretamente associada aos agentes criativos da organização gera-lhe valor econômico (REZENDE, 2002) e pode levá-la a vantagens competitivas (RAZOUK; BAYAD; WANNENMACHER, 2009).

Leonard e Sensiper (1998) associam o conhecimento tácito à inovação, quando a capacidade da mente humana, traduzida na expertise de seus funcionários e em suas perspectivas baseadas nas suas habilidades pessoais, gera novos produtos, serviços e processos.

O conhecimento tácito também se encontra associado ao desempenho organizacional (DYER; NOBEOKA, 1998; DECAROLIS; DEEDS, 1999; HSU, 2008; SHOUKAT, 2012; KORHONEN, 2014).

Conhecimento tácito, assim, é um produto mental intangível, passível de compartilhamento e em constante reformulação. Composto por elementos abstratos (ideias, raciocínios, know-how, habilidades, alegorias, modelos, constructos, insights, experiências, 
lembranças, sons, imagens, odor, gosto, tato, entre outros) é capaz de gerar novos conhecimentos e práticas inovadoras.

Quanto ao compartilhamento, a literatura apresenta o processo como não complexo ou difícil de ser implementado, ressalva, porém, a existência de lacunas de eficácia (INKPEN, 1996). Bierly, Kessler e Christensen (2000) argumentam que a sabedoria de cada empregado pode ser transformada em uma sabedoria organizacional por meio do compartilhamento de conhecimento. Dessa forma, diversas perspectivas e pontos de vista foram levados em consideração.

A essência do conhecimento tácito é o seu compartilhamento e não o seu controle (CHESHER; HOWARD, 2011). Um deslocamento ou descolamento unilateral do conhecimento tácito, quando somente uma parte beneficia-se, então, não caracteriza o agir interativo entre pessoas (BONACHE, 2010) e não configura transferência do conhecimento tácito que requer intenso contato pessoal (DAVENPORT; PRUSAK, 1999). Davenport e Prusak (1999, p. 109) ao entrevistar uma colaboradora da empresa Sematech acerca do compartilhamento de ideias, registrou o comentário: "Temos documentos, bancos de dados, intranet, web, groupware, o que você pensar. Mas os prepostos e as reuniões face a face que temos são de longe os mais importantes canais de transferência".

Taylor (1990), em sua obra Princípios de Administração Científica, embora buscasse um modelo racional, preciso, formal, matemático, the best way, também certifica a importância de desentocar ${ }^{30}$ o conhecimento mais eficiente, o tácito (MARSICK, 2009), que se encontrava alojado nos artesãos para transmiti-lo aos engenheiros, os atuais cientistas. Esse trânsito tem aumentado no decorrer das últimas décadas (GASSMANN, 2006) e afetado positivamente o desenvolvimento da capacidade de inovação de empresas (LIU, 2012).

O entendimento da natureza do conhecimento de que é muito mais tácito que explícito, bem como, de que representa inter-relações intangíveis e multidirecionais, pode servir como fonte de vantagem para a organização, na transferência, por exemplo, de melhores práticas e lições aprendidas (PORTER, 1989; FANG et al., 2007; BONACHE, 2010; CHESHER; HOWARD, 2011).

A transmissão ocorre com mais eficácia quando estabelecida em meio a conversas informais e não programadas, ou por reuniões e ações estruturadas que possibilitam a livre mobilidade do conhecimento (CARVALHO; MASCARENHAS; OLIVEIRA 2006). Na

\footnotetext{
${ }^{30}$ Ferreting out no original.
} 
“economia regida pelo conhecimento, conversar é trabalhar" (DAVENPORT; PRUSAK, 1999, p. 110).

Vieira (2009, p. 106) contextualiza um desses momentos quando cita uma experiência tida como de sucesso pelos servidores da Comarca de Casca (RS).

\begin{abstract}
Encontros sistemáticos: café da manhã realizado nas dependências do Foro, com todos os servidores e o Juiz, seguido de reunião com pauta predefinida e aberta a sugestões de todo o grupo, com o objetivo de serem tratados assuntos funcionais (...) Primeiro todos saboreiam um delicioso café da manhã conversando amenidades e, em seguida, é realizada reunião na qual há sempre uma pauta pré-estabelecida com assuntos do dia-a-dia. Nessa reunião são encaminhadas soluções para melhorar a prestação jurisdicional.
\end{abstract}

Acerca das organizações públicas, Carvalho, Mascarenhas e Oliveira (2006) assinalam que o compartilhamento pode levar a um retardo da deterioração organizacional e a um aumento de desempenho. Cuidados, entretanto, devem ser tomados, a fim de que tal fenômeno não se prenda a pressupostos burocráticos de gestão ou propriedades individuais (KERCKHOVE, 1999).

Van Caenegem (2005) ao tratar de uma possível 'regulamentação' do compartilhamento por meio da migração de pessoas entre empresas, chama a atenção para o fato de ser a socialização do conhecimento menos um protocolo normativo de relacionamento e muito mais um ato livre entre pessoas que dispõem de um conhecimento valioso e desejo de partilhar.

Organizações de vanguarda costumam incentivar o emprego do conhecimento tácito da sua força de trabalho (KRISHNAVEI; SUJATHA, 2012), tido como crucial a sua transferência dentro da organização (LEMOS; JÓIA, 2012). Tal particularidade pode aumentar as chances de difusão do conhecimento, qualidade que carece o Judiciário brasileiro (RUSCHEL, 2012), onde "em regra, não há diálogo ou troca de experiências entre os juízos" (INSTITUTO DE PESQUISA ECONÔMICA APLICADA, 2012, p. 8).

Taal (2014), contudo, quando examina o fenômeno entre juízes europeus, assinala que muitos juízes declararam que o compartilhamento não é uma atividade nova. Encontros, seminários, simpósios e eventos de natureza de aprendizagem proporcionam ambiente onde ocorre o compartilhamento.

O fenômeno, assim, transcorre em direção oposta à permanência de rotinas ultrapassadas ou inadequados. A observação da existência de conhecimento prévio (boas práticas e lições aprendidas), por exemplo, pode evitar a ocorrência da repetição de erros (SERPELL, 1993), como reporta um juiz estadual:

$\mathrm{Na}$ verdade, é que nós vamos aprendendo com as situações que vão surgindo, a gente não tem nenhuma estratégia (...) os erros podem ocorrer e ocorrem com 
frequência, daí a dificuldade de ir acertando com os erros. (SANTOS; CASTILHO; KILIMNIK., 2006, p. 12).

Até mesmo sob a perspectiva da modernização administrativa, a transmissibilidade de conhecimentos e práticas gerenciais ganha no compartilhamento um fator relevante e uma prática cada vez mais intensificada (MOTTA, 2014).

A importância do compartilhamento de conhecimento por via tácita (interações "face a face") foi reafirmada por Stefanovitz (2006) quando tratou da inovação em processos de desenvolvimento de produto. Von Hippel (1988) registrou que rápidas transferências de conhecimento realmente aumentam a capacidade da empresa de beneficiarem-se a partir de seu próprio know-how.

Da literatura também constam aspectos relacionados ao não compartilhamento. Amabile (1998) sustenta que a imobilidade ou inércia do conhecimento tácito pode estar relacionada à falta de motivação do detentor. Szulanski (2003) analisou a incapacidade organizacional de criar atmosfera para o seu trânsito; o desinteresse do receptor, a sua baixa de capacidade de absorção ou os problemas de relacionamento com o emissor. Em comunidades de prática foram apontadas: receio de mau uso; possibilidade de ataques pessoais e pouca objetividade concernente ao conhecimento compartilhado (ARDICHVILI; PAGE; WENTLING, 2003).

Ao tratar de empresas bem-sucedidas, Choo (2003) apontou que organizações que demonstraram habilidade em adaptarem-se às constantes mudanças, de inovarem continuamente e de tomarem decisões que as levaram em direção a seus objetivos demonstram capacidade de lidar com o conhecimento. Assinalou que uma organização dotada de um conjunto de conhecimentos devidamente aproveitados possui uma capacidade diferenciada das demais, de perceber, discernir e agir com inteligência e criatividade. A construção do conhecimento, assim, fica representada por um continuum de inovação que proporciona esse agir inteligente. $\mathrm{O}$ modelo proposto combina criatividade, inovação e compartilhamento do conhecimento tácito estocado sob a forma de experiência.

A ONU ao reconhecer a importância do compartilhamento, assinala em seu estudo acerca de inovação em governança para estimular os governos a trabalharem melhor juntos que o "compartilhamento de conhecimento é o primeiro passo" (ALBERTI; BERTUCCI, 2007, p. 4).

O compartilhamento pode modificar a bagagem mental instalada (TOMAÉL; ALCARÁ; DI CHIARA, 2005), permitir a criação de novos conhecimentos (NONAKA; 
TOYAMA, 2003), impulsionar a organização na sua capacidade de inovar (WILBERT et al. 2015), e até conferir à organização maior valor de mercado (TONET; PAZ, 2006).

Com dinâmica, o compartilhamento do conhecimento tácito possibilita a formação de novas ideias e novos conhecimentos, alimento da inovação (QUÉRÉ, 2003), sendo esse compartilhamento essencial para a inteligência da organização (VALENTIM, 2003).

Para algumas empresas, o compartilhamento traduz-se como um meio de garantir que os funcionários possam estar transferindo o conhecimento que detêm em prol dos que dele necessitam (TONET; PAZ, 2006).

Como o redemoinho sustenta a poeira e não a deixa depositar-se, o fenômeno do compartilhamento traz estímulos à mobilidade ao conhecimento. Exemplos dessa dinâmica são: a conversa que transfere conhecimento (DAVENPORT; PRUSAK, 1999); a estrutura espiralada (NONAKA; TAKEUCHI, 1997); e as "comunidades interpretantes" (MIRANDA; SIMEÃO, 2004) que confere novos espaços ao conhecimento.

O termo compartilhamento engloba outros vocábulos, como, transferência, distribuição, comunicação, colaboração, difusão, disseminação, alocação, network, cooperação (HEISIG, 2009, p. 9), repasse (TONET; PAZ, 2006, p. 77), interação, troca e socialização.

O compartilhamento de conhecimento tácito, assim, é um fenômeno de intercâmbio interpessoal descritível e mensurável. Representa a interação de fluxos de conhecimento tácito estabelecida entre pessoas. Pode ocorrer dentro das organizações ou entre estas, requer um ambiente de confiança social e propicia a incorporação de novos conteúdos com ganhos multilaterais de natureza agregadora.

Por ser um desafio crescente para a maioria das organizações (SMITH; MCKEEN; SINGH, 2007) e por oferecer oportunidade de interpretação (PETERAF, 1993), cresce o interesse em estudar o compartilhamento, mesmo sob a advertência de ser difícil a sua transferência (FANG et al., 2007).

Itami (1987) ao tratar do conhecimento e da habilidade em transmiti-lo como ativo organizacional invisível, salienta que, embora sejam ingredientes muito importantes para a elaboração de uma estratégia de sucesso, apresentam-se como difíceis de serem medidos. Christensen (2007) aponta que poucas são as referências de literatura e raras as empresas que incluem o compartilhamento como um componente-chave para aumento do desempenho organizacional, em razão de atribuírem como difícil a mensuração desse fenômeno. 
Por envolver elementos intangíveis internalizados em crenças, experiências e valores pessoais, colocou Inkpen (1996) que a formalização do conhecimento tácito se torna complexa em determinados contextos e difícil o seu compartilhamento.

Os resultados da pesquisa sobre Gestão do Conhecimento na Administração Pública (INSTITUTO DE PESQUISA ECONÔMICA APLICADA, 2015) seguem na mesma direção quando avaliam que os ativos intangíveis (ativos de propriedade intelectual), embora disponíveis no ambiente institucional, apresentam-se como difíceis de serem qualificados e mensurados.

Alvarenga Neto (2007, p. 22) endossa tais opiniões, salientando que por ser inerente aos seres humanos, não se compartilha o conhecimento tácito com facilidade e espontaneidade, contudo, sugere em suas conclusões a "premência na criação de um conjunto de indicadores para se medir os benefícios da GC". Sveiby (1997) vai ao encontro destas últimas considerações de Alvarenga Neto (2007). Assinala que uma estratégia focada em conhecimento pode ser quantificada, se a organização procurar medir algo além de fluxos monetários, mas também fluxos relacionados a bens intangíveis, como o conhecimento.

Longanezi, Coutinho e Bomtempo (2008) apresentaram alguns indicadores não numéricos baseados na geração de ideias: seções de brainstorm; treinamentos específicos; número de ideias apresentadas e identificação de melhores práticas. Outra ferramenta que segundo os autores compreende um processo contínuo de medição foi o benchmarking. Com relação a este, todavia, apontaram uma limitação que restringe o seu emprego, "a falta de disposição dos líderes em compartilhar indicadores realmente relevantes" (LONGANEZI; COUTINHO; BOMTEMPO, 2008, p. 81).

Para a Ciência da Informação e para os JEF é caro conhecer como se dá o compartilhamento e que variáveis estão envolvidas nesse processo, pois, segundo Ruschel (2012), os ativos tácitos são preciosos e não devem estar restritos somente às mentes dos juízes.

\subsection{TRABALHOS SELECIONADOS ACERCA DE COMPARTILHAMENTO DE CONHECIMENTO TÁCITO}

O conhecimento é transferido nas organizações, quer gerenciemos ou não esse processo. (DAVENPORT; PRUSAK, 1999, p. 107). 
Os trabalhos a seguir, brevemente apresentados, apoiaram com maior vigor a construção do pensamento teórico do pesquisador e mereceram uma seção à parte. Seus títulos correspondem ao nome dos estudiosos.

\subsubsection{Nonaka}

Ikujiro Nonaka, teórico organizacional japonês, ao contextualizar a criação do conhecimento em ambiente organizacional, entendeu ser a interação entre o conhecimento tácito e explícito a principal dinâmica geradora do conhecimento.

Conceituou o conhecimento tácito como algo de difícil visibilidade e expressão, com especial relação com as ações e as experiências do indivíduo, bem como com suas emoções, valores ou ideais. O seu modelo confere ênfase na interação pessoal, onde a chave está no compartilhamento de conhecimento (NONAKA; TAKEUCHI, 1997).

Para as organizações, a teoria aponta a necessidade de romper fronteiras que delimitam a circulação das pessoas, ideias e conhecimento. $\mathrm{O}$ indivíduo, em qualquer lugar da organização, ou fora dela, passa a ser, ao mesmo tempo, origem e beneficiário do conhecimento tácito. O processo de mobilização opera na busca do maior conjunto possível de pessoas aptas a interagirem e compartilharem seus conhecimentos.

O seu framework SECI integrado à espiral do conhecimento (Figura 1) apresenta os quatro momentos de conversão do conhecimento. O processo de criação do conhecimento desenrola-se segundo quatro modos ou momentos: socialização, externalização, combinação e internalização. 
Figura 1 - SECI integrado a espiral do conhecimento

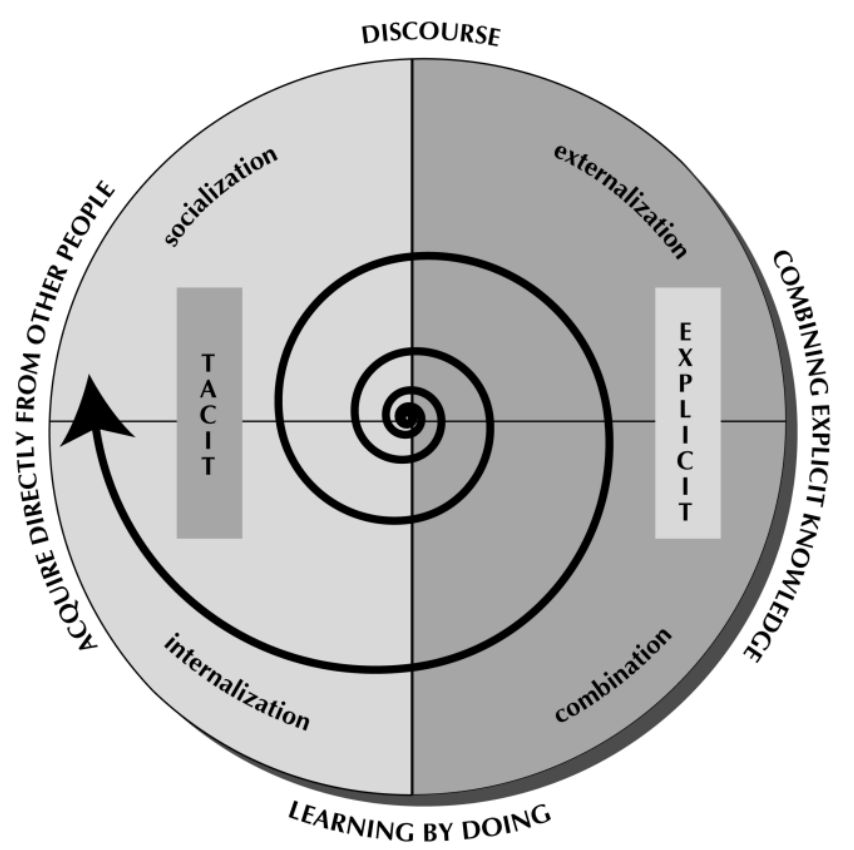

Fonte: Nonaka (1994, p. 19) e Nonaka e Takeuchi (1997, p. 80, 81).

O modo (1) socialização é um processo de compartilhamento de conteúdos mentais ainda implícitos. A comunicação se dá entre os indivíduos (tácito-tácito). O meio mais usual e eficaz é a conversação. Exemplos desse processo podem ser: troca de ideias, transmissão oral de experiências, discussões livres (brainstorm) ou críticas (lições aprendidas), aprenderolhando, aprender-fazendo ou um simples olhar severo dos pais dirigido às crianças.

Quadro 3 - Representação do conhecimento tácito para o tácito (Socialização)

\begin{tabular}{|c|c|c|}
\hline Conhecimento tácito & Conversão & Conhecimento tácito \\
\hline Conversa & & Reflexões \\
\hline Story-telling (Contar histórias) & & Crenças e valores pessoais \\
\hline Prova oral & & Resposta oral \\
\hline Entendimento do juiz & & Juízo de valor do assessor \\
\hline
\end{tabular}

Fonte: Do autor.

O modo (2) externalização é um processo de articulação do conhecimento tácito transformando-o em matéria tangível. Os conteúdos antes tácitos tomam forma fora da mente do indivíduo, em um movimento tácito-explícito, como as metáforas. Exemplos desse modo podem ser, a transformação de experiências em relatórios físicos e eletrônicos, a revelação em artigos científicos de modelos (tácitos) teóricos, a tradução de imagens mentais em desenhos, a transposição de observações em gráficos, elaboração de mapas mentais, expressão de termos colhidos em entrevistas orais em nuvem de palavras, reuniões estratégicas em BSCs, histórias de vida em documentários. 
Quadro 4 - Representação dos conhecimentos tácito para o explícito (Externalização)

\begin{tabular}{|c|c|c|}
\hline Conhecimento tácito & Conversão & Conhecimento explícito \\
\hline Vivências & & Livros \\
\hline Sons & & Partituras \\
\hline Brainstorm & $\cdots$ & Plano estratégico \\
\hline Entendimento do juiz & $\cdots$ & Sentença \\
\hline
\end{tabular}

Fonte: Do autor.

O modo (3) combinação é um processo (explícito-explícito) onde conhecimentos já explicitados transformam-se, ou seja, deixam um formato explícito para tomar outra forma explícita. Exemplos desse processo são: um desenho que se transforma em um protótipo, um molde de roupas em uma roupa, uma ferramenta em outra, um livro em filme.

Quadro 5 - Representação dos conhecimentos explícito para o explícito (Combinação)

\begin{tabular}{|c|c|c|}
\hline Conhecimento explícito & Conversão & Conhecimento explícito \\
\hline Livro & $\boldsymbol{~}$ & CD \\
\hline Desenho & $\boldsymbol{~ P r o t o ́ t i p o ~}$ \\
\hline Moldes & $\boldsymbol{~}$ & Roupas \\
\hline Sentença em papel & $\boldsymbol{~}$ & Sentença em meio eletrônico \\
\hline
\end{tabular}

Fonte: Do autor.

No modo (4) internalização, incorpora-se à mente o conhecimento proveniente ou que se assimila a partir de algum objeto existente (explícito). Colhidos pelos aparelhos humanos sensoriais, o conhecimento retorna à sua forma humana original, tácita, em movimento oposto ao da externalização.

Os conteúdos tácitos (pensamentos, insight, ideias, saber fazer e toda a gama de 'produtos' mentais) nesse processo adquirem contorno a partir de um conhecimento já explicitado. Dessa forma, reflexões surgidas a partir de um livro, raciocínios desenvolvidos frutos de uma clínica médica, o saber dirigir como resultado da interação indivíduo-veículo, vivência aprendida segundo o interagir com determinado engenho, conhecimentos desenvolvidos por meio de acesso a plataformas de comunicação são exemplos desse momento de conversão.

Quadro 6 - Representação dos conhecimentos explícito para o tácito (Internalização)

\begin{tabular}{|c|c|c|}
\hline Conhecimento explícito & Conversão & Conhecimento tácito \\
\hline Livro & & Reflexões \\
\hline Manual de medicina & & Entendimento médico \\
\hline Máquina & $\cdots$ & Saber operá-la (Know-how) \\
\hline Súmula & $\cdots$ & Entendimento jurídico \\
\hline
\end{tabular}

Fonte: Do autor.

O quadrante tácito-tácito em que indivíduos compartilham seus conhecimentos, caracteriza-se por ser a origem de todo o processo. A inexistência ou comprometimento desse fluxo interpessoal pode prejudicar ou inviabilizar, além da criação de novos conhecimentos, a transformação do conhecimento tácito em explícito (fase da externalização) e o seu emprego 
posterior, seja na combinação de registros que já foram externalizados ou na internalização de novos registros.

Merece uma breve consideração o fato de os autores iniciarem os conceitos dos modos de conversão pelo termo "processo" (NONAKA, 1994, p. 19; NONAKA; TAKEUCHI, 1997, p. $69,71,75,77)$. O exame do vocábulo traz como significados "seguimento, marcha, operação, sequência, atividade" (FERREIRA, 2010, p. 1712), "seguimento, ação" (PRIBERAM, 2010), "sequência, operação, transformação" (CUNHA, 2008, p. 293), "ordem, sequência, execução de atos" (SILVA, 2008, p. 1103), "procedimento, maneira de operar ou de agir, devir ou desenvolvimento" (ABBAGNANO, 2007, p. 935-936).

Conhecimento, no processo de formação de política de empreendedorismo para os atores do setor público, envolve movimento (desse conhecimento), segundo a sua complexidade (METS, 2012).

Dessa forma, parece não causar distorção aos conceitos de Nonaka e Takeuchi (1997) se fosse executada a permuta dos termos [processo] por [movimento], estabelecendo para cada modo de conversão um movimento ${ }^{31}$. O modo socialização, então, pode ser compreendido como um movimento de compartilhamento de ideias, experiências, modelos conceituais e toda a sorte de conteúdos dessa natureza, pois quando se trata de aspectos tácitos é necessária a socialização (OLIVEIRA, 2000, p.18).

A contribuição do modelo de Nonaka e Takeuchi (1997) à pesquisa passa pelo modelo de criação e compartilhamento de conhecimento tácito. A espiral do conhecimento permitiu ao pesquisador elaborar a ideia de circulação de conhecimento tácito nos JEF e contribuiu para a formulação da pergunta-problema da pesquisa: quais variáveis, na ótica dos juízes, explicam o compartilhamento do conhecimento tácito no âmbito dos JEF do Brasil?

A definição do modo de conversão "tácito-tácito" tratada por Nonaka e Takeuchi (1997) como "socialização" incitou à formulação da hipótese, onde possíveis variáveis relacionadas à pessoa do juiz e associadas a propensão em compartilhar foram inseridas.

\subsubsection{Sveiby}

Sveiby (1997) introduz o seu modelo tratando de estruturas de conhecimento visíveis e invisíveis. Elenca dentre os bens (ativos) intangíveis, a competência dos empregados, o relacionamento com clientes, marcas, modo de gestão, conhecimento e experiência.

\footnotetext{
31 Como a pesquisa tem por objeto o compartilhamento, a substituição será apresentada somente no modo Socialização.
} 
O autor define algumas organizações como 'organizações de conhecimento', caracterizando seus funcionários como 'trabalhadores do conhecimento'. Nessas organizações, os ativos intangíveis possuem muito mais valor que seu patrimônio tangível, o conhecimento ganha valor quando é compartilhado e aquele que toma a ação de transmitir (emissor) acaba tendo um aumento de seu estoque de conhecimento por meio da interação com as pessoas que compõem o processo de compartilhamento (os receptores ${ }^{32}$ ).

Em 'organizações do conhecimento', o autor aponta quatro principais protagonistas: $o$ profissional, o gestor, a equipe de apoio e o líder. Essas quatro categorias atuam simultaneamente segundo as suas competências profissional e organizacional (Figura 2).

Figura 2 - As quatro categorias pessoais em organizações do conhecimento

\begin{tabular}{|c|c|c|}
\hline \multicolumn{3}{|c|}{ Competências organizacionais } \\
\hline$\cdot \frac{\tilde{J}}{0} \cdot \frac{\infty}{\Xi}$ & O profissional & O líder \\
\hline 坣: & A equipe de apoio & O gestor \\
\hline
\end{tabular}

Fonte: Sveiby (1997, p. 54).

Em contexto organizacional, para conceituar competência, Sveiby (1997) engloba habilidade, experiência, juízo de valor e rede social. No que diz respeito às competências profissionais, Sveiby (1997) compara as organizações de conhecimento com consulting firms (firmas de consultoria) que trafegam indistintamente em ambientes público e privado. Em tais organizações, o profissional (também denominado expert) é o consultor, o indivíduo-chave, o elo entre o cliente e a organização. A dependência do cliente com o consultor é muito mais forte do que a do cliente ou a do consultor com a firma. O papel dos executivos-chefe é sempre o de garantir uma maior autonomia a esses consultores, pois, na realidade, são eles os responsáveis pelas receitas. Sveiby (1997) adverte os gestores a proporcionar 'a mais proveitosa arena' de trabalho a eles, pois são os mais valiosos empregados da organização.

Os gestores apresentam-se como deficientes na competência relacionada ao conhecimento e aptos quanto às competências organizacionais. Enquanto os profissionais focam sua atenção em questões ligadas ao conhecimento, os gestores guardam ênfase em controle.

A equipe de apoio em organizações do conhecimento participa do fluxo do conhecimento essencial. A ligação é motivada pelos profissionais que ao contar com seu

\footnotetext{
${ }^{32}$ As posições de 'emissor' e 'receptor' alternam-se constantemente. Essa peculiaridade é própria do fenômeno de compartilhamento que por ser dinâmico e multilateral permite emissões e recepções durante todo o processo. Dessa forma, é característica do fenômeno a trânsito recíproco de conhecimento.
} 
apoio também alinham esse apoio com as questões nucleares do negócio. Por vezes, o relacionamento acontece em salas de conferência ou corredores.

Os líderes mostram-se competentes em ambas vertentes, organizacional e profissional. Pertencem a mesma profissão dos experts, mas não precisam ser excelentes como estes (Maestro e instrumentista; diretor de teatro e ator). No entanto, agem para que o melhor de cada um aflore. Dos líderes exigem habilidades em formar a visão e dar concretude aos objetivos, bem como, uma rara capacidade comunicativa.

Organizações do conhecimento têm seus fluxos de conhecimento como suas próprias estruturas internas que incluem seus sistemas administrativos de apoio aos profissionais (experts). Gerenciar tais estruturas significa gerenciar a organização, o que não exige tecnologia da informação.

Sveiby (1997) ao tratar do conhecimento tácito, assevera que trabalhadores do conhecimento costumam subestimá-lo. No entanto, reconhece que o conhecimento tácito do expert está sempre lá e em todo tempo vai colorir os resultados finais.

Ao contemplar a possibilidade de mensurar bens intangíveis, Sveiby (1997) relata experiências com medições de valores empregados em Pesquisa \&Desenvolvimento, mas assinala não ser um bom parâmetro. "Fluxos de conhecimento e bens intangíveis são essencialmente não-financeiros. Precisamos de novas proxies" (SVEIBY, 1997, p. 156).

Ao examinar possibilidade de medir as estruturas internas, Sveiby (1997) apresenta várias experiências onde se implementaram sistemas de medida para bens intangíveis. Entre elas:

- Relatórios anuais de empresas na Suécia (WM-Data e Skandia) mostraram Den Osynliga Balansräkningen (balanços invisíveis) com indicadores procedendo medições sobre espírito de corpo, competência, modo de gerenciar, sentimento de segurança, nível de habilidade do empregado e grau de boas relações com o mercado (WM-Data). O modelo utilizado na Skandia media foco no cliente (número de clientes ganho e perdido), foco no processo (custo administrativo por empregado), foco no empregado (custo de capacitação/treinamento por empregado) e foco em desenvolvimento (índice de satisfação do empregado). A empresa dinamarquesa PLS-Consult apresenta como um dos seus indicadores dos ativos intangíveis o Conhecimento Intelectual (qualificações acadêmicas e antiguidade).

- Auditorias de conhecimento da empresa sueca Celemi foram baseadas em uma avaliação do desempenho dos ativos intangíveis. O "balanço invisível” da empresa 
mostrou três categorias: "Nossos Clientes", onde se mediu, entre outros indicadores, a sua reputação e imagem com base em sua capacidade de resolver problemas a partir da demanda dos clientes. "Nossa Organização" mensurava o grau de confiança de seus empregados em desenvolver soluções internas e para os clientes. "Nossas Pessoas" avaliava o valor dos colaboradores quanto as suas habilidades em agir em um amplo espectro de situações.

Sveiby (1997) assinala que indicadores alternativos podem prover novos e interessantes ângulos e serem de grande valor aos gestores. Coloca que desde 1950 as empresas têm se debruçado na elaboração de indicadores não monetários que possam colaborar com estudos de desempenho organizacional. Salienta, contudo, que uma das dificuldades em apresentar tais iniciativas é a de não existir um modelo teórico rigoroso para este tipo de medição.

\subsubsection{Davenport e Prusak}

Os autores destacam a importância de as organizações baseadas em conhecimento terem o controle dos componentes necessários à produção de conhecimento, com observância do desenvolvimento de estratégias específicas para incentivar trocas.

Assumindo o compartilhamento como um dos elementos essenciais à organização, salientam que há uma profusão do conhecimento, contudo, destacam que existência não significa emprego.

A importância de as organizações voltarem seus olhos para um compartilhamento espontâneo e não estruturado do conhecimento, papel fundamental dos processos de gestão do conhecimento, fortalece e incita o aparecimento de estratégias específicas de estímulo a tais trocas.

Acerca da informalidade inerente ao compartilhamento, destacam que conversas em torno de bebedouros ou nos restaurantes são oportunidades de compartilhamento e que atribuir a esse momento 'perda de tempo', faz parte de uma teoria ultrapassada sobre a natureza do trabalho. Ressalvam, contudo, que não seria uma atitude sensata aguardar ao lado de uma sala de lanches uma resposta para um conhecimento específico, porém, reafirmam que encontros espontâneos de mentes (transferências não estruturadas) têm revelado uma capacidade de gerar novas ideias ou resolver problemas antigos de forma inesperada.

Como maneiras de estimularem a troca de conhecimentos, Davenport e Prusak (1999) esclarecem que uma maior eficácia pode ser obtida quando as narrativas ocorrem frente a 
frente e citam a estruturação de 'mercados de conhecimento', lugares onde os colaboradores podem cambiar ideias e experiências de maneira informal.

$\mathrm{Na}$ cultura da transferência do conhecimento, atritos podem retardar ou mesmo obstruir o fluxo comunicativo. Os autores apontam alguns:

- Falta de confiança mútua;

- $\quad$ Falta de tempo e de locais para encontro;

- $\quad$ Síndrome do 'não inventado aqui' ${ }^{33}$;

- Intolerância com erros ou necessidade de ajuda.

\subsubsection{Miranda e Simeão}

O estudo apresentado pelos autores trata da transferência de informação. Todavia, em sua parte introdutória, ao tecerem comentários sobre a 'informação tecnológica', os autores acusam a existência de outros elementos, não tão discerníveis, porém de alto valor para a transferência da informação.

Em alguns trechos do trabalho tais elementos são citados: "conjunto de saberes e fazeres"; "concessão de know-how específico" e "via de regra, o que se transfere é o how-to$d o "$. (MIRANDA; SIMEÃO, 2004, p. 4).

Em outro momento, assinalam o caráter irrevogável da interação humana na transferência, inserindo implicitamente o conhecimento tácito. Obviamente, que tanto a transferência de informação quanto de tecnologia se fazem de pessoa para pessoa e tal conotação humanística é inalienável (MIRANDA; SIMEÃO, 2004, p. 5).

Essa observação guarda uma relação já salientada por Nonaka e Takeuchi (1997) quando destacam a importância do conhecimento tácito na conversão ao conhecimento explícito (a informação).

Tem-se como pouco provável que todo o conhecimento pudesse estar reproduzido explicitamente na informação depositada no processo de transferência porque sabemos mais do que podemos expressar (POLANYI, 2009).

Os autores ainda argumentam que na transferência de informação é imprescindível que grupos de pessoas de características culturais semelhantes estejam presentes. O estudo tipifica os grupos como "comunidades interpretantes" que estabelecem um compartilhamento

\footnotetext{
${ }^{33}$ A literatura é farta de material que trata dessa síndrome, 'not invented here (nih). Autores descrevem que, pelo fato de uma ideia ou inovação não ter surgido no próprio ambiente de trabalho ou não ter sido conduzida pelos membros internos da unidade ou da organização, a solução não possui "as características necessárias" e por isso não deve ser considerada.
} 
segundo códigos específicos e criam novos conhecimentos (MIRANDA; SIMEÃO, 2004, p. $5)$.

O modelo (Figura 3) aponta as comunidades e acusa a existência de um fluxo nas estruturas informais de comunicação compostas essencialmente por pessoas que as constituem e as identificam: colégios invisíveis, congressos, simpósios, fóruns.

O trabalho apresenta uma interatividade na vertente pessoal que une, por meio de um 'problema', emissor e receptor. Essa comunicação, apesar de registrada em um sistema, não desconsidera outro processo de comunicação de caráter intangível.

O modelo, ao propor uma comunicação baseada nas possibilidades tecnológicas, não deixa de considerar outra 'extensividade', a estrutura informal paralela, externa, implícita, contudo, presente no ambiente formal/informal da transferência da informação.

É esse movimento caracterizado pelo fluxo comunicativo interpessoal que esta tese trata por compartilhamento do conhecimento tácito.

\section{Figura 3 - Política de Transferência de Informação}

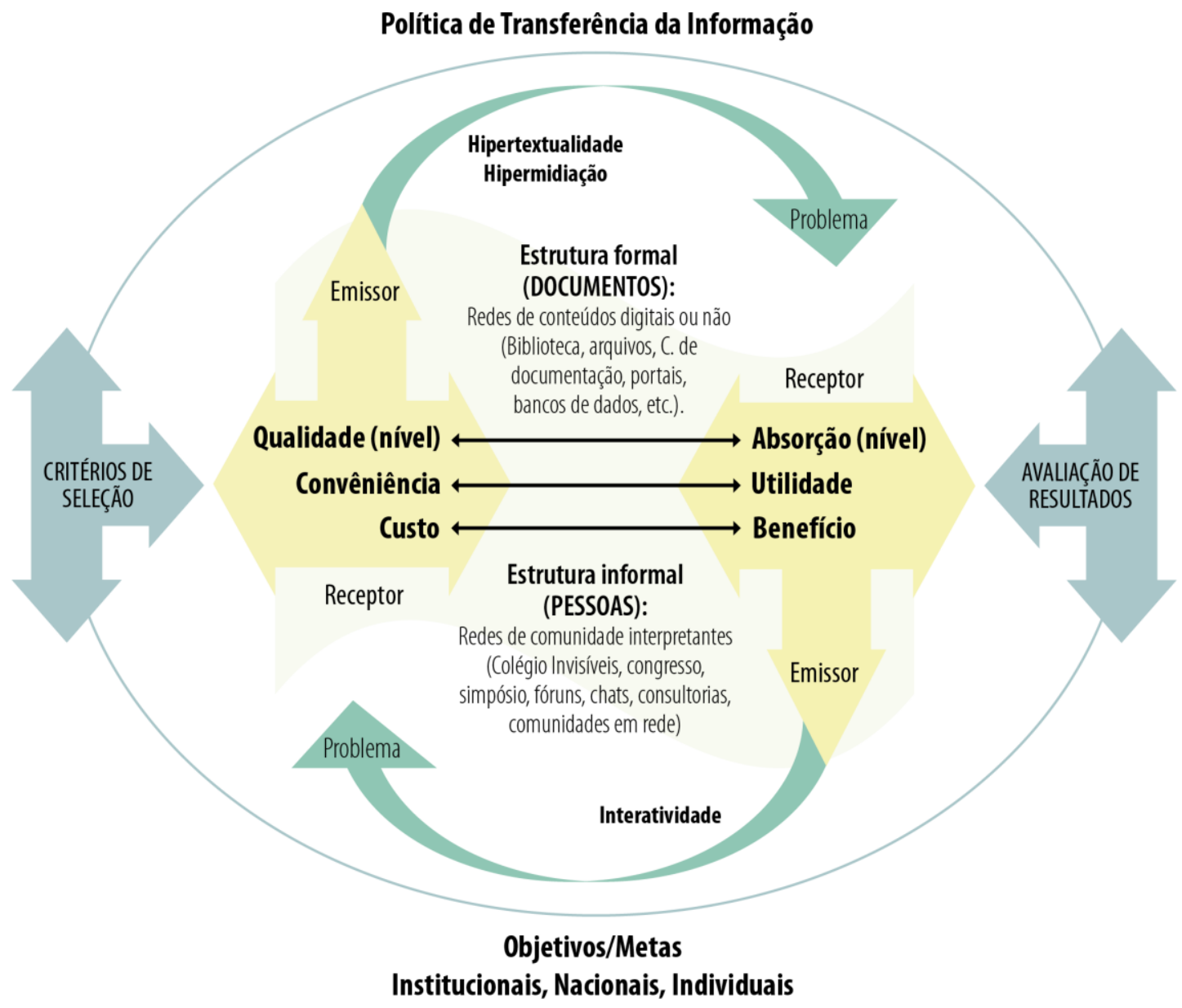

Fonte: Miranda e Simeão (2004). 


\subsubsection{Tonet e Paz (2006)}

A proposta deste modelo busca contribuir na compreensão do fenômeno do compartilhamento, examinando os seus elementos constitutivos, a eficiência e os resultados com foco em grupos de sujeitos.

O modelo dos autores prevê quatro fases: iniciação, implementação, apoio e incorporação. A primeira caracteriza-se, entre outros tópicos, por localizar fontes onde o conhecimento pode ser recuperado, quando ocorre uma dinâmica de busca e troca do conhecimento. Os autores chamam a atenção para a entrada de novos membros devido à necessidade de repasse de conhecimento. Alertam, contudo, para que seja feita uma avaliação do nível de conhecimento inicial, porque "repassar-lhe aquilo que já domina, além de tedioso, seria perda de tempo" (TONET; PAZ, 2006, p. 81).

Consideram também como pertencente a esta fase o processo de indução ao compartilhamento dentro da própria unidade de trabalho para a busca de solução de problemas ou para atender demandas por conhecimento. A importância desta fase aumenta com o nível de dificuldade que há para "perceber oportunidades de transferir a outros conhecimentos úteis já dominados" (TONET; PAZ, 2006, p. 82) ou diante de situações desfavoráveis à organização que poderão ser revertidas com o compartilhamento do conhecimento.

A segunda fase identifica integração fonte-destinatário. A terceira, trata de ações voltadas para criar atmosfera de compartilhamento e a quarta busca verificar ações desenvolvidas para o livre compartilhar. A figura abaixo apresenta o modelo.

\section{Figura 4 - Modelo de Compartilhamento de Conhecimento Tonet e Paz}

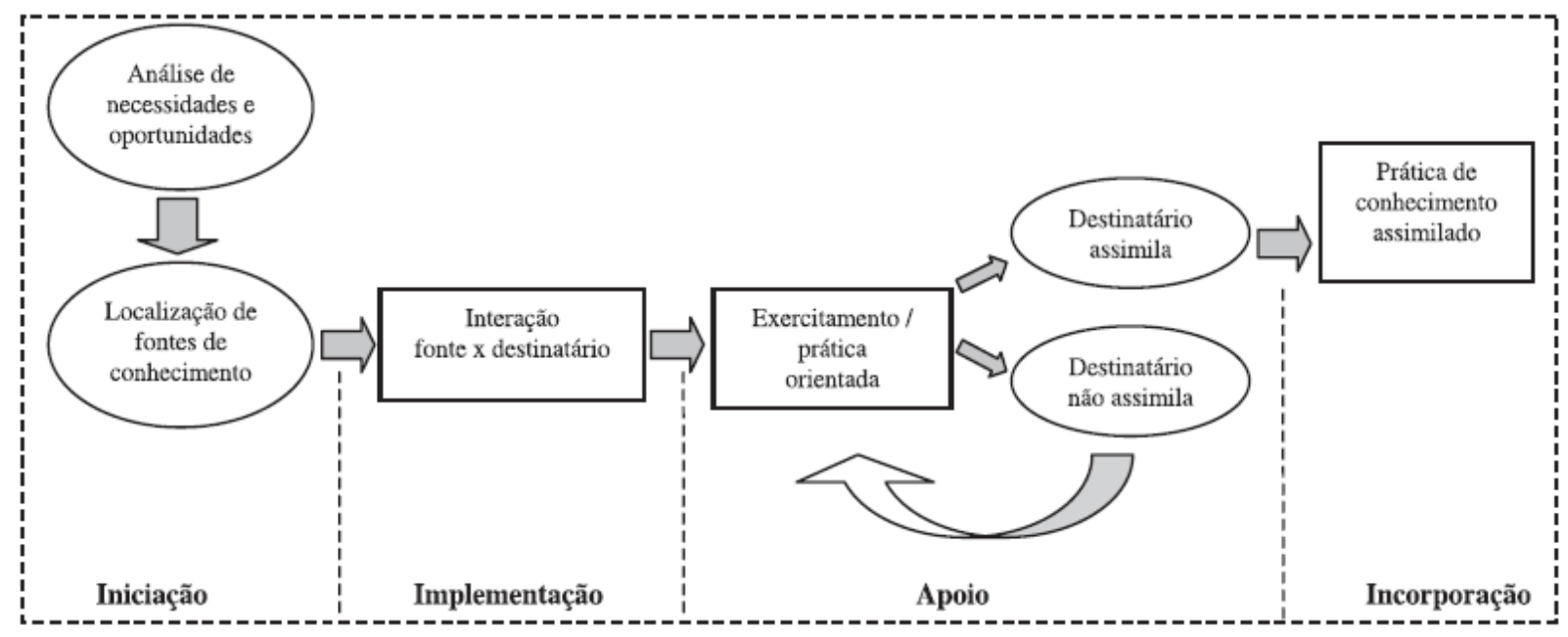

Fonte: Tonet e Paz (2006, p. 81). 


\subsubsection{Souza e Batista}

O modelo de Souza e Batista (2008) traz um exame sobre os efeitos do movimento do conhecimento organizacional entre países desenvolvidos. Acrescenta que o compartilhamento de conhecimento permite que ideias transitem de um país a outro, levando inovação e gerando uma capacidade internacional de produção de bens cujo núcleo é a "transferibilidade" conhecimento. Transferibilidade essa que pode tomar forma de compartilhamento de conhecimento.

O autor sustenta que a inovação é maior em empresas que detêm uma cultura relacionada mais ao compartilhamento do conhecimento que a uma determinada estrutura organizacional. $\mathrm{O}$ modelo prediz que em caso de falta de compartilhamento de conhecimento as vantagens inovadoras não alcançam todo o espectro de produtos.

Outra consequência observada relaciona-se com a baixa mobilidade do conhecimento ou a sua falta. As ideias, experiências e habilidades tendem a causar impactos já na fase final do produto e não nas suas fases iniciais (como na fase de Pesquisa e Desenvolvimento P\&D) reduzindo-se a possibilidade de melhorias e aprimoramentos no decorrer da cadeia produtiva.

A contribuição maior do trabalho, segundo o autor, está no fato de, tratando-se de uma alocação efetiva de conhecimento, a falta de uma mobilidade do conhecimento pode vir a comprometer a produção e reduzir a inovação e o crescimento do negócio.

\subsection{COMPARTILHAMENTO DE CONHECIMENTO NO JUDICIÁRIO}

Vós sois a nossa carta. (TARSO apud BIBLIOGRAFIA..., 2016).

Esta seção objetiva trazer alguns trabalhos no âmbito do Judiciário que trazem de forma direta ou indiretamente o compartilhamento do conhecimento como tema.

\subsubsection{A comunidade de prática virtual como ferramenta da GC}

Essa proposta estudou uma comunidade de prática formada por membros das Divisões de Apoio ao Usuário e Infraestrutura do Tribunal de Justiça de Pernambuco (TJ-PE). Foram levados em consideração para a análise da fluência do conhecimento, ideias, experiências, intuição, habilidades e competências.

\footnotetext{
${ }^{34}$ Transferability no original
} 
O problema levantado pela pesquisa denotou "a inexistência de prática organizada que aumente o fluxo de conhecimento nos setores, ou seja, o conhecimento permanece individualizado" (SILVA, 2004, p. 29).

Utilizando a ferramenta Communis, voltada para GC, que permite discutir problemas, pesquisar opiniões com apoio estatístico, criar e reusar informações e discutir, gravar e recuperar conversas, a pesquisa buscou integrar os membros das citadas Divisões segundo um processo de socialização.

A pesquisa informou os benefícios da ferramenta e os fatores de sucesso para GC. Segundo a análise do pesquisador quanto ao ambiente, observou-se a seguinte relação:

Quadro 7 - Quadro de fatores de sucesso para GC versus situação no TJ-PE

\begin{tabular}{|l|l|}
\hline \multicolumn{1}{|c|}{ Fatores de sucesso para GC } & \multicolumn{1}{c|}{ Situação } \\
\hline Cultura para o conhecimento & $\begin{array}{l}\text { O TJPE “está praticamente no marco inicial" e "falta de interesse em } \\
\text { compartilhar", }\end{array}$ \\
\hline Infra-estrutura técnica & $\begin{array}{l}\text { O TJPE "tem um grande parque de computadores, (...) com Internet } \\
\text { rápida" }\end{array}$ \\
\hline Infra-estrutura organizacional & "não atende as expectativas" \\
\hline Apoio institucional à proposta & $\begin{array}{l}\text { "há incertezas porque a cada biênio ocorrem mudanças da } \\
\text { administração do Tribunal" }\end{array}$ \\
\hline
\end{tabular}

Fonte: SILVA, 2004, p. 50-51.

Com o fim de avaliar a GC, foram propostos dois indicadores:

a) Número de acessos à ferramenta Communis - "através desse quantitativo é possível saber quantas pessoas acessaram a comunidade" (SILVA, 2004, p. 70);

b) Número de contribuições à comunidade - "através do envio de documentos, arquivos, trabalho, indica uma participação na comunidade e conhecimento de GC” (SILVA, 2004, p. 70).

Os resultados esperados com a proposta foram, o aumento do fluxo de conhecimento; o desenvolvimento de habilidades e competências dos funcionários; a melhoria do gerenciamento do capital humano; o aumento da satisfação dos clientes internos e externos (sociedade); a promoção da colaboração, incentivando o compartilhamento global de conhecimento; e por fim tornar-se uma semente para a generalização do uso de práticas da GC no TJ-PE.

Para trabalhos futuros, o estudo sugeriu avaliar as relações entre a GC e possíveis variáveis nas dimensões: social, tecnológica, organizacional e pessoal. 


\subsubsection{Paradigma para o Judiciário fluminense}

$\mathrm{Na}$ análise da pesquisa desenvolvida por um servidor do Tribunal de Justiça do Estado do Rio de Janeiro cujo objetivo foi o de

demonstrar que investir em GC irá possibilitar um retorno expressivo para a
instituição, objetivando tornar a prestação jurisdicional mais ágil e efetiva,
contribuindo para a potencial melhoria da nossa imagem como instituição (GOMES,
2005, p. 6).

puderam ser observados cinco momentos que guardaram relacionamento com o conhecimento.

O primeiro passo dado em direção ao alcance do objetivo foi a criação da Diretoria Geral de GC (DGCON), “mesmo sob a cética ‘supervisão’ de indivíduos pertencentes aos setores mais tradicionais" (GOMES, 2005, p. 8). A origem dessa unidade deriva de um mapeamento de macroprocessos de trabalho quando se verificou que um dos processos-chave seria a gestão do saber organizacional.

A DGCON estava subdivida nos seguintes departamentos: Gestão do Ciclo do Conhecimento (DECCO), Gestão de Acervos Arquivísticos (DEGEA), Gestão de Acervos Bibliográficos (DERAB) e Gestão do Museu da Justiça (DEGEM). O critério de criação e estruturação levou em conta que tais unidades traziam como competência áreas e serviços relacionados ao conhecimento e funcionavam como suporte à atividade jurisdicional.

A forma de interação mais utilizada, com o fim de integrar os diretores foi "a reunião, maneira mais salutar de resolução de problemas e de compartilhamento de experiências e ponto de vista" (GOMES, 2005, p. 29).

Posteriormente, em um segundo momento, estabeleceu-se uma parceria com a Escola da Magistratura do Rio de Janeiro (EMERJ) e a Escola de Administração Judiciária (ESAJ), com o objetivo de recuperar e compartilhar o conhecimento estocado por essas duas unidades.

O terceiro estágio deu-se com a elaboração do Plano Diretor, onde constavam iniciativas associadas à GC (Anexo K), tais como: criação da página da DGCON no portal corporativo; Banco de Conhecimento; definição das políticas de disseminação das informações do Poder Judiciário; e apresentação em eventos institucionais e organização de palestras. Esta última iniciativa foi incorporada ao Programa de Integração Funcional que somou, com palestras, reuniões e encontros, mais de 1500 ouvintes entre gestores de todos os níveis.

A quarta fase caracterizou-se por duas ações. A primeira, que tratava do 'Banco de Conhecimento', implementada por meio do Projeto "Enunciados Administrativos", visava padronizar as decisões. A marca desse projeto está, entre outros atributos, na 
multidisciplinaridade e na visão compartilhada. Almejava o empreendimento constituir-se em um instrumento capaz de possibilitar a recuperação dos conhecimentos mais relevantes provenientes de diversas fontes, entre elas, comunidades de prática. Por conhecimento interno, definiu-se "o que é produzido por magistrados e servidores no exercício das atividades jurisdicional e administrativa (...) [tais como] jurisprudências, doutrina, pareceres e decisões" (GOMES, 2005, p. 36).

Para estímulo a essa produção, entre outras medidas, foi sugerido "a promoção de eventos internos que facilitem a integração" (GOMES, 2005, p. 38).

A segunda ação, 'Redefinição do Portal Corporativo', visava gerenciar o processo de publicação de conteúdos e até o fim do estudo não foi concluída. A terceira, 'Definição das Políticas de Disseminação das Informações', objetivava a elaboração de políticas relacionadas, entre outros aspectos, à disseminação de conteúdo e acesso aos conhecimentos produzidos internamente, considerando "que esse conjunto se caracteriza como recurso estratégico para o desenvolvimento organizacional e a melhoria dos processos de trabalho relacionados à prestação jurisdicional” (GOMES, 2005, p. 34).

Um dos resultados obtidos com essa ação foi a conversão de conhecimentos tácitos em explícitos, com a "socialização do saber em benefício da própria organização" (idem). A quinta e última etapa privilegiou o aprimoramento intelectual quando

\footnotetext{
Foram oferecidos, entre outros, cursos de Gestão de Pessoas, de Comunicação Estratégica, de Indicadores de Desempenho, de Normas ISO, além de PósGraduação latu sensu em Administração Judiciária (FGV/EBAPE) e Gestão do Conhecimento (UFRJ/COPPE/CRIE). (GOMES, 2005, p. 40).
}

Findados os cursos, ficavam as pessoas incumbidas de compartilhar o conhecimento recebido. A própria DGCON promovia encontros destinados ao compartilhamento, como o denominado 'Highlight DGCON: compartilhando conhecimento'.

Essa experiência levou a organização "a desejar apropriar-se de novos knowhow desenvolvidos por outras empresas e instituições (...) admitindo que a troca de experiência é fundamental para o desenvolvimento da GC na administração pública” (GOMES, 2005, p. 42) e realizar diversas visitas externas ao Tribunal (Anexo H) com o propósito de compartilhar os conhecimentos absorvidos com as atividades desenvolvidas e permitir a incorporação de outros. 


\subsubsection{Melhores práticas em uma base de dados no Tribunal Regional Federal da Primeira Região}

O estudo de Miranda e Moresi (2010) iniciou-se anunciando medidas necessárias a lidar com um novo ambiente que cerca o Judiciário, em especial, o TRF1. Esse novo cenário, fortemente baseado no conhecimento, requeria novas posturas.

Os pesquisadores chamaram a atenção para o conhecimento experimentado e registrado em melhores práticas, bem como, para a importância de não o deixar inerte, sem movimento, preso a algum repositório físico ou eletrônico.

O estudo conduziu uma pesquisa quantitativa, por meio de questionário distribuído a 317 juízes federais da $1^{\text {a }}$ Região (175 válidos). O instrumento de coleta de dados foi dividido em quatro partes: perfil do magistrado (gênero, faixa etária, formação acadêmica, tempo na magistratura, estado em que atua); fluxo do conhecimento/informação na Instituição; ambiente interno; e facilitador organizacional. Ao termo 'conhecimento' foi atribuído o teor tácito e à 'informação', a forma explícita.

Com relação ao fluxo do conhecimento, buscou-se verificar se os juízes sabiam onde encontrar o recurso no TRF, nas pessoas, em suas dependências físicas, ou em seus repositórios eletrônicos. Mostraram-se indecisos 29,14\% e 37,70\% apresentaram baixa concordância. Observou-se que 74,28\% dos juízes desconhecem que existem os especialistas. $\mathrm{Na}$ avaliação de 'A geração de novas ideias, produtos ou serviços ocorre com frequência', quando no âmbito do TRF, apenas 22,28\% concordaram e $32 \%$ dos juízes não souberam avaliar. Quando se tratou de avaliar se ' $O$ compartilhamento do conhecimento ajuda o bom desempenho do TRF e das SJ', 82,26\% concordaram, sendo que 55,42\%, plenamente.

No que diz respeito ao ambiente interno, $65,13 \%$ dos respondentes discordaram quando tiveram que opinar sobre disponibilidade de tempo para troca de conhecimento, embora $62,27 \%$ concordaram que buscam sugestões junto aos colegas para resolver problemas surgidos no trabalho. Na avaliação quanto ao trabalho em grupo, $57,12 \%$ dos respondentes discordaram. Quando se questionou sobre 'Temos uma cultura de compartilhamento do conhecimento', $25,14 \%$ dos juízes não souberam avaliar, 17,71\% ficaram indecisos e apenas $13,13 \%$ concordaram. Especificamente quanto aos juízes, para a indagação 'Os magistrados têm interesse em compartilhar', dos respondentes apenas 36,57\% concordaram, 26,28\% mostraram-se indecisos e 34,27\% discordaram.

Nos aspectos que pudessem favorecer o compartilhamento, com relação à existência de comunidades de prática, $22,28 \%$ dos juízes mostraram-se indecisos, 37,71\% 
compartilhariam mais se houvesse incentivo e $39,42 \%$ tenderam a discordar quanto ao TRF1 propiciar encontros para compartilhar experiências. Aproximadamente $40 \%$ concordam que copiariam um projeto em vez de "reinventar a roda".

Como conclusões apontadas pela pesquisa, algumas variáveis devem ser consideradas, entre elas (MIRANDA; MORESI, 2010, p. 427):
a identificação dos fatores que influenciam a transferência do conhecimento; a disseminação das melhores práticas podem conduzir a economia de recursos; as redes sociais no trabalho são importantes veículos para o compartilhamento do conhecimento;
o desafio da gestão é criar um ambiente que, verdadeiramente, valorize o compartilhamento.

\subsubsection{Modelo de conhecimento para apoio ao juiz na fase processual trabalhista}

As gestões dos tribunais sempre viram como afronta (...) o compartilhamento sistematizado de informações (RUSCHEL, 2012, p. 92).

O autor quando discorre sobre o compartilhamento assinala que os ativos de conhecimento, dentre eles o conhecimento tácito de especialistas como os juízes, não deveriam ficar indisponíveis em suas mentes, dado o seu valor, tanto para a sociedade, quanto ao próprio sistema judiciário. Argumenta que "tais ativos e o seu compartilhamento certamente melhorará a prestação jurisdicional brasileira” (RUSCHEL, 2012, p. 93).

O Modelo de Conhecimento desenvolvido, associado às tecnologias de informação e comunicação (TIC), busca explicar a tipologia e a estrutura do conhecimento empregado pelo juiz durante as tarefas relacionadas ao ato de apreciar e julgar uma demanda judicial. Permite uma descrição dos elementos que compõem o processo de resolução dos problemas relativos ao julgamento que envolve ativos do conhecimento e direito processual. Por fim, o modelo foi ajustado "para atender a 'maneira de trabalhar' do juiz e tornar produtivo o exercício do especialista" (RUSCHEL, 2012, p. 108), sendo o autor o Engenheiro do Conhecimento (EC) e mediador do sistema proposto.

\section{Figura 5 - As relações do Engenheiro do Conhecimento}

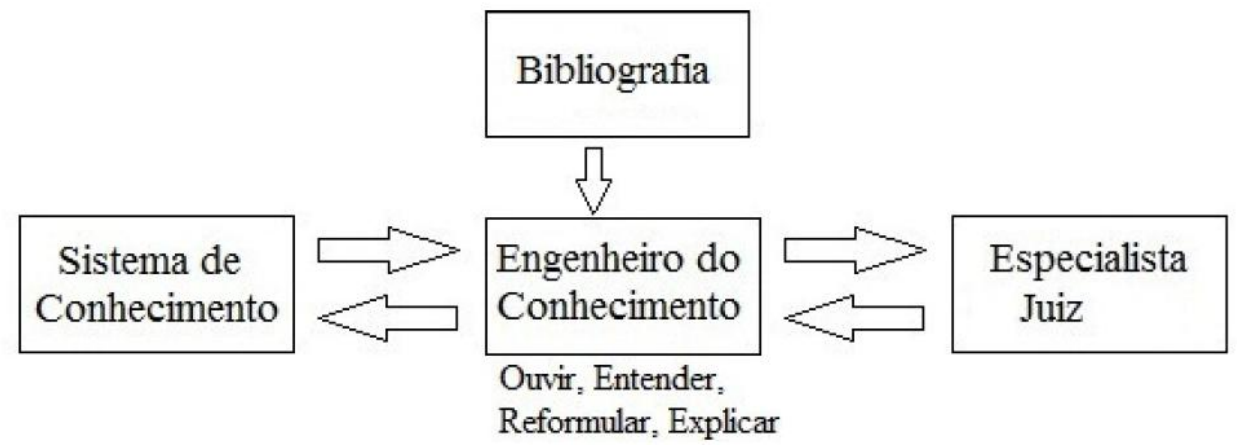

Fonte: Ruschel (2012, p. 108). 
O EC considera a bibliografia jurídica para poder dialogar com o juiz e propõe processos de solução para os problemas que se relacionam com o julgamento.

Há três pontos básicos que caracterizam as demandas, segundo o modelo:

1. o detalhamento das competências [do juiz] envolvidas na execução dos processos;

2. a representação dos processos de trabalho; e

3. as oportunidades de melhoria no que tange ao processo e ao uso do conhecimento. (RUSCHEL, 2012, p. 103).

O compartilhamento de conhecimento tácito entre o juiz e o EC decorrente do processo de elaboração do modelo, segundo Ruschel (2012), permitiu ao juiz perceber: a) a consciência daquilo que realizava em termos do seu conhecimento empregado na resolução dos conflitos; b) qual tipo de conhecimento preocupava-o durante o processo de análise e julgamento dos pedidos; c) a possibilidade de outro juiz reusar seus conhecimentos tácitos para a formulação de uma decisão pode levar os juízes a aprenderem com análises processuais já efetuadas por outros anteriormente; e d) a presença de uma não propensão ao compartilhamento de conhecimento tácito por parte dos juízes, com uma associação dessa indisposição a aspectos relacionados à cultura organizacional e poder.

Pôde o juiz do Trabalho, conforme Ruschel (2012), também verificar que: (1) o seu ativo mental poderia ser aprimorado por ele próprio ou por meio de compartilhamentos com seus pares; (2) as 'provas vivas' colhidas durante as audiências permaneciam em sua memória e eram empregadas na análise dos casos; (3) um juiz influenciou no trabalho e no conhecimento do outro; (4) o compartilhamento de conhecimento tácito provocou a ocorrência de insight; (5) o conhecimento tácito não compartilhado pode se perder por falta de uso; (6) a sua busca mental por caminhos que o levassem à solução do pedido judicial levou-o a um aprendizado; (7) o seu conhecimento tácito é um elemento do processo judicial; (8) as varas do trabalho e outros setores a ela relacionados geralmente não demonstraram motivação em compartilhar; (9) as principais tarefas dos juízes e de suas equipes configuram atividades intensivas em conhecimento; (10) os juízes mais experientes tem um conhecimento maior que os iniciantes; (11) a qualidade do conhecimento que pode vir a alimentar o sistema depende das habilidades (knowhow, skills) inerentes aos juízes; (12) uma das competências dos membros de sua equipe de trabalho é compartilhar com ele, o juiz, situações processuais e contribuir para o estabelecimento de um ambiente de confiança.

Todas as situações acima descritas ocorreram durante os momentos de compartilhamento. Permitiram não somente a possibilidade de externalização do conhecimento tácito (para compor fases dos processos do modelo informatizado), mas, e principalmente, uma dinâmica interpessoal de profunda integração e aumento de volumes de 
conhecimento tácito para todos os profissionais envolvidos, com possibilidade de uso individual e organizacional.

Uma síntese crítica a respeito da revisão de literatura esclareceu as opções feitas pelo pesquisador no encaminhamento do estudo. Até meados do século XX, encontravam-se as organizações baseadas em modelos industriais focados em recursos materiais, físicos, tangíveis. Este modelo ficou conhecido por Abordagem Industrial / Organizacional ( $\mathrm{I} / \mathrm{O}$ approach).

Na década de 1950, inicia Penrose (2006) estudos que apontam o conhecimento como um ingrediente estratégico no modus operandi das empresas que se destacavam segundo os seus desempenhos. Essa tendência contribuiu com a abordagem 'Visão Baseada em Recursos (VBR)' e, em um segundo momento, com a 'Visão Baseada em Conhecimento (VBC)' que determinaram estudos e práticas futuras, onde o conhecimento e o conhecimento tácito, posteriormente, ganharam significado e relevância.

O pesquisador quando frequentou eventos de caráter presencial, onde os juízes discutiam seus processos de trabalho e a gestão de suas Varas e Foros, identificou uma dinâmica peculiar na forma de comunicação desses juízes. Enquanto alguns compartilhavam as suas ideias e propostas, outros apresentavam uma 'taxa de interação' baixa.

Outro aspecto que chamou a atenção do pesquisador foi o fato de os juízes compartilharem o seu conhecimento ainda na forma tácita, ou seja, o conhecimento que fluía nas conversas ainda se encontrava na forma implícita, como um conteúdo mental, destituído de base material, física ou virtual. O conhecimento compartilhado não provinha de manuais, livros, sistemas informatizados ou qualquer outra forma de mídia.

A literatura revisada apontou trabalhos onde se verificou haver base para supor que no processo comunicativo humano, como o dos juízes, flui conhecimento tácito e que variáveis poderiam estar associadas a este fenômeno que a pesquisa tratou por 'compartilhamento do conhecimento tácito'.

Com base nesses estudos, o pesquisador pôde estabelecer uma triangulação de sujeitos, uma rede de interação. Elegendo o juiz como agente central dos JEF, na rede mensurou-se o grau de interação entre o juiz e seus pares, os ASJ e os membros de sua equipe de trabalho.

Mesmo sob a advertência de alguns autores, contudo, autorizado por outros, o pesquisador mediu o nível de interação e verificou que variáveis colhidas na literatura e em sua própria experiência explicavam o compartilhamento do conhecimento tácito. 
Como frutos desse exame, dois conceitos foram propostos pelo pesquisador. Conhecimento tácito foi tido como um produto mental intangível, passível de compartilhamento e em constante reformulação. Composto por elementos abstratos (ideias, raciocínios, know-how, habilidades, alegorias, modelos, constructos, insights, experiências, lembranças, sons, imagens, odor, gosto, tato, entre outros) é capaz de gerar novos conhecimentos e práticas inovadoras.

O compartilhamento de conhecimento tácito foi traduzido como um fenômeno de intercâmbio interpessoal descritível e mensurável. Representa a interação de fluxos de conhecimento tácito estabelecida entre pessoas. Pode ocorrer dentro das organizações ou entre estas, requer um ambiente de confiança social e propicia a incorporação de novos conteúdos com ganhos multilaterais de natureza agregadora. 


\section{METODOLOGIA}

Minha segunda máxima consistia em ser tão firme e tão resoluto quanto possível em meus atos. (DESCARTES, 2006, p. 34).

\subsection{AMBIENTE DA PESQUISA}

\subsubsection{O Poder Judiciário}

O Poder Judiciário é um dos poderes federativos do Brasil e é composto pelo Supremo Tribunal Federal (STF), com sede na Capital Federal, com 11 Ministros. Atua como órgão de cúpula, guardião da Constituição, tendo como função a de ser o tribunal de federação, conforme expressa o artigo 102 (BRASIL, 1988).

Compõem ainda o Poder Judiciário:

1) o Superior Tribunal de Justiça (STJ), também com sede na Capital Federal com

jurisdição nacional e com competência para dar a última palavra em matéria subconstitucional, exercendo, assim, o controle da inteireza positiva, da autoridade e da uniformidade de interpretação da lei federal, juntamente com a competência originária (SILVA JÚNIOR, 2008, p. 1).

2) o Tribunal Superior do Trabalho (TST) e Juízes do Trabalho ${ }^{35}$ que compõem a Justiça do Trabalho que

concilia e julga as ações judiciais entre trabalhadores e empregadores e outras controvérsias decorrentes da relação de trabalho, bem como as demandas que tenham origem no cumprimento de suas próprias sentenças, inclusive as coletivas. (BRASIL, 2015a, p.1).

3) a Justiça Eleitoral formada pelo Tribunal Superior Eleitoral (TSE) e pelos Juízes Eleitorais ${ }^{36}$ como

um ramo especializado do Poder Judiciário, com atuação em três esferas: jurisdicional, em que se destaca a competência para julgar questões eleitorais; administrativa, na qual é responsável pela organização e realização de eleições, referendos e plebiscitos; e regulamentar, em que elabora normas referentes ao processo eleitoral. (BRASIL, 2015b, p.1).

4) o Tribunal Superior Militar (TSM) e Juízes Militares que como Justiça Militar velam

pela aplicação da lei à categoria dos militares federais e estaduais, de acordo com a legislação específica. Ela se divide em Justiça Militar da União e as Justiças Militares Estaduais. (GUIA DE DIREITOS, 2015, p. 1).

5) os Tribunais e Juízes dos Estados e do Distrito Federal e Territórios ${ }^{37}$. A Justiça Estadual,

${ }^{35}$ O Tribunal Superior do Trabalho (TST), com sede na Capital Federal, centraliza os Tribunais Regionais do Trabalho (TRT), localizados nas unidades federativas.

${ }^{36}$ Idem, guardando a devida especialidade. Dessa forma, têm-se o Tribunal Superior Eleitoral (TSE) e os Tribunais Regionais Eleitorais (TRE). 
integrante da Justiça comum (junto com a Justiça Federal), é responsável por julgar matérias que não sejam da competência dos demais segmentos do Judiciário Federal, do Trabalho, Eleitoral e Militar. Ou seja, sua competência é residual. (BRASIL, 2015c, p. 1).

6) Os Tribunais Regionais Federais $\left(\mathrm{TRF}^{38}\right)$ e Juízes Federais que compõem a Justiça Federal.

\subsubsection{A Justiça Federal}

O nascimento da Justiça Federal coincide com a instauração da nova ordem política, a República. Mesmo antes de promulgada a primeira Constituição, Campos Sales já apresentava a Deodoro da Fonseca o projeto que viria a ser depois o Decreto 848, de 11 de outubro de 1890, cuja ementa informava a organização da Justiça Federal.

Criada para atuar no lugar do antigo Tribunal Federal de Recursos, estruturou-se a Justiça Federal segundo Tribunais Regionais Federais (TRF) e introduziu o federalismo regional, pelo menos no âmbito da Justiça Federal (SILVA JÚNIOR, 2008).

Os TRF, com sedes em uma das capitais pertencentes a sua respectiva Região ${ }^{39}$, servem como grau de recurso $\left(2^{\circ}\right.$ grau) às ações impetradas no $1^{\circ}$ grau (Subseções e Seções $\left.{ }^{40}\right)$.

O juiz federal é o órgão da Justiça Federal, titular de cada uma das Varas competentes

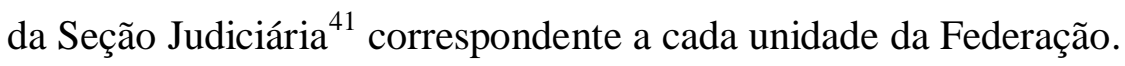

A estrutura interna dessas Seções pode, de forma resumida, ser assim representada: unidades judiciais, comumente tratadas por Varas, que se subdividem em duas unidades. Uma, de natureza de secretaria, onde os autos recebem um tratamento mais relacionado aos ritos processuais e é dirigida por um diretor. A outra unidade, Gabinete, assessora o juiz quanto a aspectos afetos a elaboração das decisões judiciais propriamente ditas ${ }^{42}$.

Cada Vara possui um juiz federal titular e outro substituto.

${ }^{37}$ Art. 92, da Constituição Federal (CF). (BRASIL, 1988).

${ }^{38}$ As Regiões também são conhecidas pelas siglas de seus respectivos tribunais. A $1^{\text {a }}$ Região, TRF1, abrange os estados do Acre, Amapá, Amazonas, Bahia, Goiás, Maranhão, Mato Grosso, Minas Gerais, Pará, Piauí, Rondônia, Roraima, Tocantins e o Distrito Federal. A $2^{\mathrm{a}}$ Região, TRF2, Rio de Janeiro e Espírito Santo. A $3^{\mathrm{a}}$, TRF3, São Paulo e Mato Grosso do Sul. A 4 ${ }^{\mathrm{a}}$, TRF4, Rio Grande do Sul, Paraná e Santa Catarina, e a 5a, TRF5, Pernambuco, Sergipe, Alagoas, Paraíba, Rio Grande do Norte e Ceará.

${ }^{39}$ TRF1 está situado em Brasília-DF, o TRF2, no Rio de Janeiro-RJ, o TRF3, em São Paulo-SP, o TRF4, em Porto Alegre-RS e o TRF5, em Recife-PE.

${ }^{40}$ As Seções estão localizadas nas capitais. As Subseções, no interior, em localidades que apresentam ou reúnem volumes expressivos de ações ou por sua posição estratégica no cenário sócio-político-econômico nacional.

${ }^{41}$ Em grandes cidades do interior, há o que se chama Subseções. Por apresentarem estrutura semelhante às das Seções a análise dar-se-á somente sobre estas.

${ }^{42}$ Com a introdução do processo eletrônico, essas unidades reclamam uma nova estrutura. A força de trabalho deixa o manuseio e transporte de processos físicos para acompanhar um trâmite eletrônico, efetuando com maior agilidade a alocação de informações oportunas e necessárias. O tempo de construção das peças agora passou a ser maior que o trâmite físico anterior, transferindo o gargalo para os gabinetes. 
O Juiz Titular é aquele que está investido em sua autoridade de juiz, seja singular ou único (...). Vulgarmente, pode-se dizer, é o dono da vara ou do juízo, em que funciona, pelo caráter de efetivo e de permanente, em que é tido. E assim, se distingue do juiz substituto. Este, togado de carreira que ingressa no Poder Judiciário mediante concurso de provas e títulos. Tem por principal função substituir ou auxiliar os juízes titulares. (SILVA, 2008, p. 794).

Administrativamente, as Varas apoiam-se em unidades administrativas. Entre elas, citam-se: Controle Interno, Recursos Humanos (Capacitação, Legislação, Pagamento, Cadastro de Pessoal e Assistência Social), Modernização Administrativa (inovação em processos de trabalho e planejamento estratégico), Tecnologia da Informação e Comunicação (TIC), Orçamento e Finanças, Compras e Licitação, Transporte e Segurança, Material e Patrimônio, Comunicação Social ${ }^{43}$, Biblioteca e Arquivo Judicial e Administrativo).

As Seções subordinam-se aos seus respectivos Tribunais, conforme a região onde estão estabelecidas. Ligadas às Seções estão as Subseções, criadas em razão da necessidade de interiorizar a Justiça Federal. Cada Seção possui um conjunto de varas, algumas delas como Juizados Especiais Cíveis e Criminais ${ }^{44}$ no âmbito da Justiça Federal, ou simplesmente, JEF.

\subsubsection{Os Juizados Especiais Federais (JEF)}

A real inovação na estrutura do Judiciário brasileiro, operada com a Constituição de 1988, foi a previsão de criação dos juizados especiais civis e criminais, respectivamente, para o julgamento e a execução das causas cíveis de menor complexidade e infrações de menor potencial ofensivo (SILVA JÚNIOR, 2008, p.1).

A Emenda Constitucional n. 22, de 18 de março de 1999, ao acrescer o parágrafo único no art. 98 da CF, impôs a criação dos JEF, suprindo a omissão da Carta Magna quando tratou da instalação desses juizados apenas na Justiça Estadual. (BRASIL, 1999).

A Lei n. ${ }^{\circ} 10.259$, de 12 de julho de 2001, ao instituir os JEF, também definiu suas competências, cível e criminal e a complexidade das causas.

Art. $2^{\mathrm{o}}$ Compete ao Juizado Especial Federal Criminal processar e julgar os feitos de competência da Justiça Federal relativos às infrações de menor potencial ofensivo $[\ldots]$;

Art. $3^{-}$Compete ao Juizado Especial Federal Cível processar, conciliar e julgar causas de competência da Justiça Federal até o valor de sessenta salários mínimos [...]. (BRASIL, 2001, p. 1).

No grau de recurso às decisões dos juízes das Varas JEF, figuram as Turmas Recursais. A dupla subordinação dá-se em razão de os aspectos administrativos serem tratados pelo juiz Diretor do Foro (da Seção ou da Subseção) e os aspectos judiciários, pela Turma Recursal, em caso de recurso e outros procedimentos.

\footnotetext{
${ }^{43}$ Algumas Seções não possuem essa unidade.

${ }^{44}$ Em razão do volume de ações de pequeno porte, em alguns municípios são encontradas JEF Adjuntos que se utilizam da estrutura de varas comuns para processar feitos de caráter especial, ou seja, de JEF.
} 
Não há subordinação das Turmas ao Diretor do Foro. Em cada Região existe a Coordenação dos JEF (COJEF) que, dirigida por um desembargador federal, administra de forma geral projetos e programas ${ }^{45}$ referentes aos JEF.

A figura 6 mostra o organograma simplificado da Justiça Federal, com destaque às Varas JEF. O organograma apresentado é fruto de uma composição dada pela Lei $n^{\circ} 5.010$, de 30 de maio 1966 que regulamenta a organização da Justiça Federal brasileira, com cada um dos Estados, Territórios e o Distrito Federal constituindo uma Seção Judiciária (sua primeira instância), sendo agrupados em cinco regiões judiciárias (BRASIL, 1996). As Seções localizam-se nas capitais e as Subseções em cidades do interior dos Estados. As Turmas Recursais, como se viu, apresentam-se como grau de recurso (segundo grau) aos processos que tramitam nas Varas JEF, primeiro grau ou instância.

\section{Figura 6 - Organograma simplificado da Justiça Federal, com os JEF.}

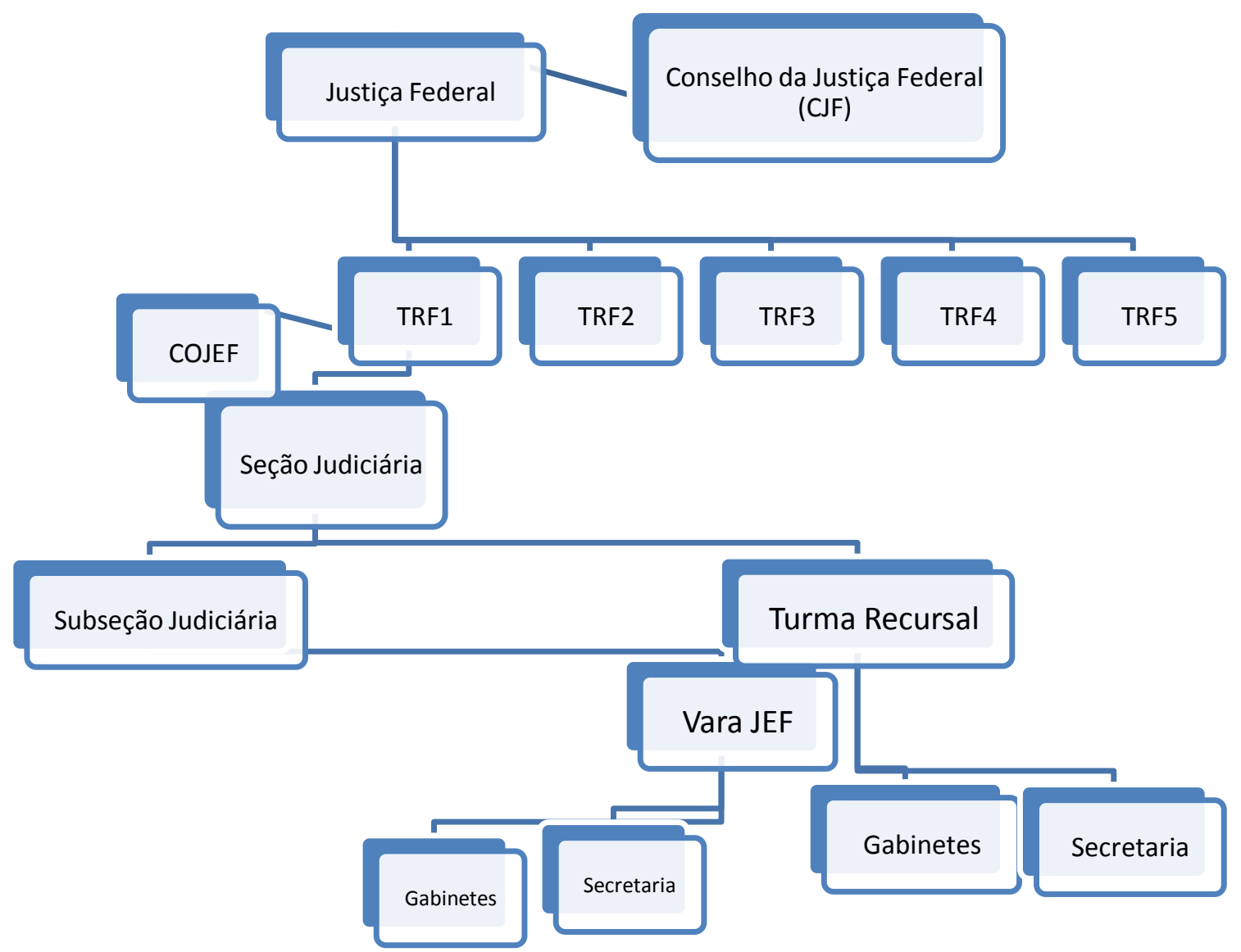

Fonte: Do autor.

As Varas possuem cargos para os dois juízes, o titular e o substituto e obedecem a uma subdivisão interna. De maneira geral, o Gabinete atua com mais ênfase na elaboração das

\footnotetext{
${ }^{45}$ Dentre outras tarefas, citam-se as de organizar e executar mutirões de julgamento e JEF itinerantes.
} 
decisões e sentenças e é composta precipuamente por Analistas Judiciários com formação em Direito. Em algumas Regiões são chamados de Assessores em outras, Oficiais de Gabinete. Pode-se dizer que o Gabinete é subdividido em dois, um que atende ao juiz titular e outro, ao juiz substituto.

A outra seção da Vara denominada Secretaria é administrada por um diretor e congrega Analistas e Técnicos Judiciais não necessariamente com formação superior em Direito. Em algumas Varas, nota-se a presença de "terceirizados" que geralmente atuam no atendimento. A Secretaria gerencia o trâmite dos autos e, entre outras tarefas, conduz o pagamento de peritos, a expedição de Precatórios ${ }^{46}$, o atendimento e a intimação das partes.

As Varas, pertencentes às unidades judiciárias distribuídas por todo o país, atingem as cinco Regiões e milhares de municípios, conforme se observa no gráfico 3, onde as Varas $\mathrm{JEF}^{47}$ estão discriminadas.

\footnotetext{
${ }^{46}$ O caput do art. 100 da Constituição Federal prevê que o pagamento de valor devido pela Fazenda Federal será processado por expedição de Precatório. Nos JEF, pelo valor atribuído pela lei às causas, o Precatório é tratado por Requisição de Pequeno Valor (RPV). Para melhor entendimento do conceito, ver Fonseca (2008).

${ }^{47}$ Foram tomados como sujeitos da amostra juízes pertencentes às Varas JEF e as Varas com Juizado Adjunto. Estas últimas englobam em uma única Vara competências de Vara comum e de Vara JEF.
} 


\section{Gráfico 3 - Unidades Judiciárias de $1^{0}$ Grau da Justiça Federal}

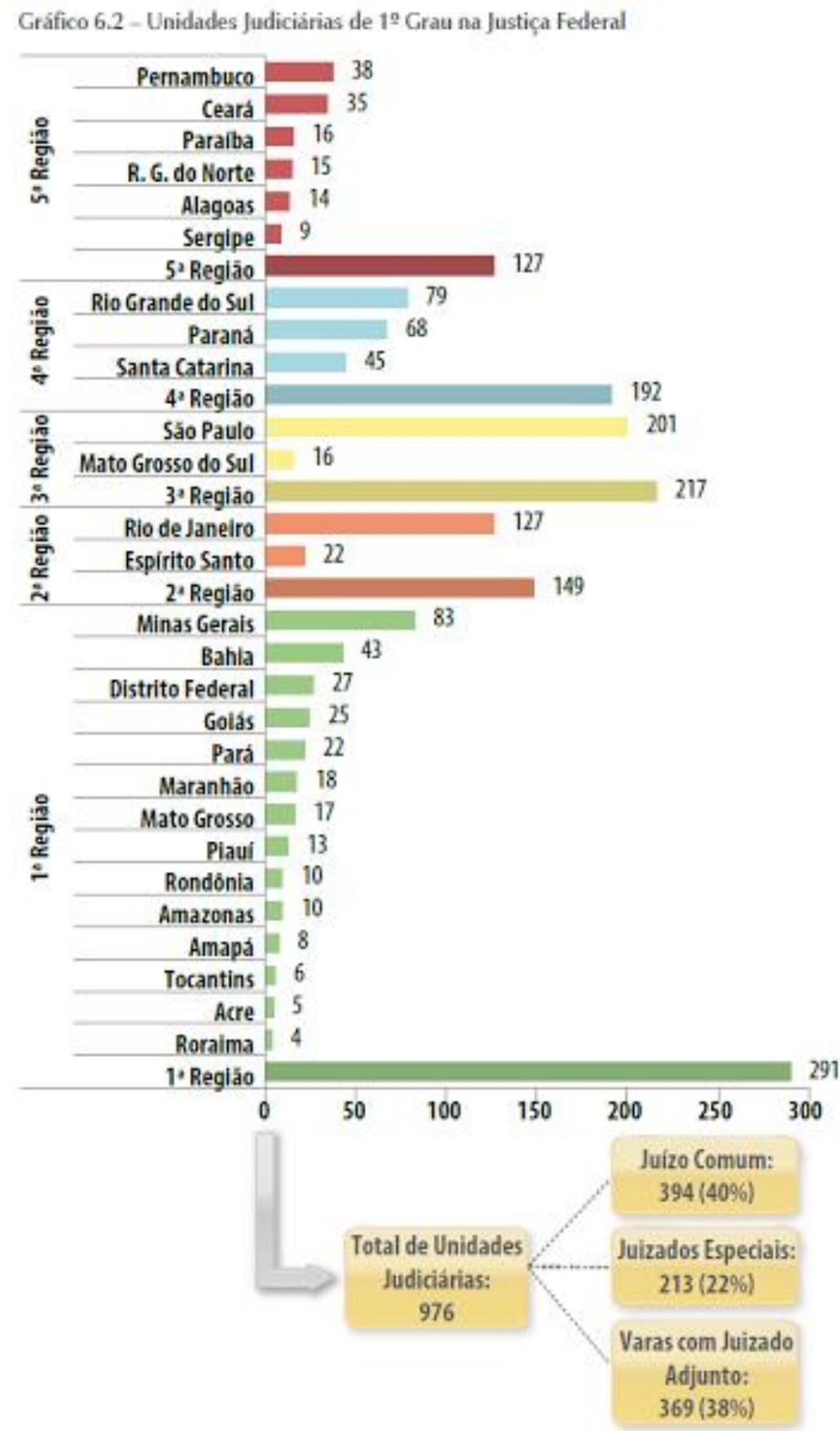

Fonte: Relatório Justiça em Números 2015/2014 (BRASIL, 2015, p. 271).

A Turma Recursal (TR), instância recursal dos JEF, é composta por três juízes de primeiro grau. É composta por uma Secretaria administrada por um Diretor e três Gabinetes, um para cada juiz, com suas respectivas assessorias.

Apesar de recentes em solo brasileiro, os juizados especiais, em sua essência, são bem antigas.

o surgimento dos Juizados Especiais - ao menos de um órgão jurisdicional que com ele aguarde similitude - remonta à Inglaterra do século XI, consagrado também pela legislação austríaca em 1873. Nos Estados Unidos, a experiência pôde ser observada 
já a partir de 1912, com a instituição do Poor Man's Court. [...] Na Noruega, instituiu-se um sistema, nos fins do século XIX, tendo por objetivo proteger os camponeses que não podiam pagar advogados. Não obstante, é na Alemanha que os Juizados Especiais aparecem com maior expressão, a partir do modelo de reformas proposto por Fritz Baur em 1965, denominado Stuttgarter Moddel. (BRASIL, 2000, p. 19-20).

O legislador, por meio da Lei N. 10.259, de 12 de julho de 2001, ao instituir os JEF, pareceu almejar um trâmite mais simples e rápido (BRASIL, 2001). Acolheu subsidiariamente os critérios (princípios) anteriormente estabelecidos pela lei que dispõe sobre os Juizados Especiais Cíveis e Criminais (âmbito estadual), Lei N. 9.099, de 26 de setembro de 1995:

Art. $2^{\circ} \mathrm{O}$ processo orientar-se-á pelos critérios da oralidade, simplicidade, informalidade, economia processual e celeridade, buscando, sempre que possível, a conciliação ou a transação" (BRASIL, 1995, p. 1, grifo nosso).

Criados para ocuparem o espaço das "pequenas causas federais", no campo criminal, "processar e julgar os feitos [...] relativos às infrações de menor potencial ofensivo" e, no campo cível, "processar, conciliar e julgar causas [...] até o valor de sessenta salários mínimos" (BRASIL, 2001, p. 1), os JEF, além de seus critérios norteadores, trazem especificidades interessantes:

a) Apresentam em seu acervo um volume considerável de ações em formato eletrônico. Essa realidade atinge dois terços dos JEF, com destaque aos maiores centros urbanos, onde esse formato alcança 85,7\% (INSTITUTO DE PESQUISA ECONÔMICA APLICADA, 2012).

b) Representam uma fatia hipossuficiente ${ }^{48}$ da população;

A hipossuficiência da parte autora é explícita quando ela se senta de um lado da mesa da sala de audiência, desassistida e pleiteando um benefício de natureza alimentar, e a União, devidamente representada pelos procuradores concursados da autarquia-ré, se posiciona no lado contrário. (SILVA, 2010, p. 8).

c) Possuem um acervo expressivo relacionado a causas assistenciais (INSTITUTO DE PESQUISA ECONÔMICA APLICADA, 2012).

d) A partir do julgamento de ações, em determinadas regiões, pode-se verificar o impacto econômico e financeiro considerável que o pagamento de direitos pode trazer a pequenas cidades, suas vilas e povoados. A título de exemplo, em Teresina-PI, em 2009, foram realizados 10 mutirões quando foram julgados 19.565 processos, com pagamento de $\mathrm{R} \$ 52.123 .304,48$ em RPV (BRASIL, 2014b, p. 26);

e) O contato das partes com os juízes é mais próximo e as decisões costumam ser mais céleres que em uma vara comum.

\footnotetext{
${ }^{48}$ Essa terminologia é empregada nos JEF para se referir às partes economicamente menos favorecidas.
} 
Existem vários ritos (caminhos) definidos por lei, de acordo com o tipo de processo. Alguns são muito demorados, outros têm duração um pouco menor e por fim temos um rito que se pretende seja o mais rápido possível. Esses ritos são, nessa ordem, 1) rito ordinário, 2) rito sumário e 3) rito sumaríssimo. O rito ordinário é um caminho mais tortuoso e longo até o final do processo. Ele requer uma sequência maior de atos processuais. O rito sumário é mais concentrado e por isso exige menos atos, sendo, portanto, mais curto e mais célere (ágil). O rito sumaríssimo é o menor de todos eles. É ele o rito dos juizados. (BRASIL, 2015).

f) Possuem um expressivo volume de processos

Quadro 8 - Movimentação Processual dos JEF em âmbito nacional

\begin{tabular}{|c|c|c|c|}
\hline Processos/Ano & $\mathbf{2 0 1 2}$ & $\mathbf{2 0 1 3}$ & $\mathbf{2 0 1 4}$ \\
\hline Distribuídos & 382794 & 479144 & 659841 \\
\hline Julgados & 422381 & 455066 & 484966 \\
\hline Remetidos à TR* & 150299 & 2647 & 763538 \\
\hline Tramitação** & 622760 & 608982 \\
\hline
\end{tabular}

Fonte: Quadro elaborado pelo autor com dados provenientes do Observatório da Estratégia da Justiça Federal. Nota: *Turma Recursal. **Processos não julgados que compõem o acervo inicial do ano seguinte. Posição em 31.12.

g) "o campo dos Juizados Especiais é fértil para desenvolver novas ideias e aperfeiçoar o sistema judiciário nacional”. (BACELLAR, 2004, p. 35).

Apesar de na Justiça "as tarefas intensivas em conhecimento continuarem a ser realizadas de forma manual" (RUSCHEL, 2012, p. 49), percebe-se, segundo Sveiby (1997), a existência de alguns princípios característicos da organização do conhecimento que podem ser encontrados nos JEF, em contraposição aos argumentos de uma abordagem industrial, mais rígida, formal e burocrática. 
Quadro 9 - Paradigma comparativo de princípios de uma organização do conhecimento dentro do contexto dos JEF

\begin{tabular}{|c|c|c|}
\hline $\begin{array}{l}\text { Paradigma de } \\
\text { indústria }\end{array}$ & $\begin{array}{l}\text { Paradigma do } \\
\text { conhecimento }\end{array}$ & Contexto do JEF \\
\hline $\begin{array}{l}\text { Subordinados sob } \\
\text { supervisão }\end{array}$ & $\begin{array}{l}\text { Colegas apoiam-se } \\
\text { mutuamente }\end{array}$ & $\begin{array}{l}\text { Intensa troca de conhecimento e informação } \\
\text { sobre características das ações judiciais. }\end{array}$ \\
\hline $\begin{array}{l}\text { Controle da } \\
\text { informação }\end{array}$ & $\begin{array}{l}\text { Mecanismos para } \\
\text { comunicar a informação }\end{array}$ & $\begin{array}{c}\text { Sistemas integrados de processo eletrônico onde } \\
\text { todos monitoram tudo. }\end{array}$ \\
\hline $\begin{array}{l}\text { Pessoas processam } \\
\text { recursos tangíveis } \\
\text { em produtos }\end{array}$ & $\begin{array}{c}\text { Trabalhadores do } \\
\text { conhecimento convertem } \\
\text { conhecimento em estruturas } \\
\text { intangíveis }\end{array}$ & $\begin{array}{l}\text { Juízes e servidores que, em determinadas fases } \\
\text { do rito processual, colhem conhecimento das } \\
\text { partes e dos ASJ como subsídios ao processo } \\
\text { decisório (mental) do juiz }\end{array}$ \\
\hline $\begin{array}{c}\text { Fluxo de informação } \\
\text { via hierarquia } \\
\text { organizacional }\end{array}$ & $\begin{array}{l}\text { Fluxo via rede entre colegas } \\
\text { de trabalho }\end{array}$ & $\begin{array}{c}\text { Fluxo via rede entre servidores, juízes, ASJ, } \\
\text { peritos, médicos, assistentes sociais, Varas, } \\
\text { Central de Perícia, JEF em outras cidades e } \\
\text { estados, entre outros. }\end{array}$ \\
\hline $\begin{array}{l}\text { Gargalos do } \\
\text { processo com } \\
\text { origem em falta de } \\
\text { capital }\end{array}$ & $\begin{array}{l}\text { Gargalos por falta de } \\
\text { conhecimento }\end{array}$ & $\begin{array}{l}\text { Há juízes que praticam e criam uma atmosfera } \\
\text { de compartilhamento. }\end{array}$ \\
\hline $\begin{array}{l}\text { Produção } \\
\text { relacionada a } \\
\text { produtos tangíveis }\end{array}$ & $\begin{array}{l}\text { Estruturas de produção de } \\
\text { bens intangíveis }\end{array}$ & $\begin{array}{c}\text { Na Vara JEF, preza-se o relacionamento de } \\
\text { juízes com as partes, com os ASJ e com os } \\
\text { servidores quando conhecimentos são } \\
\text { intercambiados. }\end{array}$ \\
\hline $\begin{array}{l}\text { Relação unilateral } \\
\text { com os clientes via } \\
\text { mercado }\end{array}$ & $\begin{array}{l}\text { Relacionamento via } \\
\text { interação pessoal }\end{array}$ & $\begin{array}{l}\text { O relacionamento dos juízes e servidores com } \\
\text { as partes e ASJ acontecem de forma presencial } \\
\text { (durante as audiências e por ocasião dos } \\
\text { atendimentos de balcão para fornecer } \\
\text { informações e dirimir dúvidas). O } \\
\text { relacionamento dos juízes com os servidores } \\
\text { acontece diariamente durante todo o tempo do } \\
\text { expediente principalmente de forma presencial. }\end{array}$ \\
\hline
\end{tabular}

Fonte: Adaptado de Sveiby (1997).

Os JEF, assim, nesse contexto, e como instituições de produção, compartilhamento e consumo de conhecimento foram tomados como organizações do conhecimento. Esse reconhecimento empresta um predicado especial ao trabalho que substancialmente trata de conhecimento tácito e seu compartilhamento.

${ }^{49}$ Conforme se viu na seção 2.2.2, estruturas intangíveis podem ser, entre outras, marcas, relacionamento com fornecedores e clientes, modo de gestão, estrutura legal, atitudes, software, conhecimento e experiência. 


\subsection{POPULAÇÃO E AMOSTRA DA PESQUISA}

A população-alvo do estudo foi definida em 879 juízes federais, titulares ou substitutos, com lotação em Vara JEF, Vara JEF Adjunto ou Turma Recursal das cinco regiões da Justiça Federal. Dado o tamanho e a dispersão do universo da pesquisa, optou-se por trabalhar com amostragem probabilística.

Em processos de amostragem probabilística, são conhecidas as probabilidades de seleção de cada indivíduo que compõe a população. Dessa forma, ao ser selecionada a amostra, cada indivíduo teve um peso calculado (fator de expansão) o que possibilitou a inferência dos resultados da amostra para toda a população.

Existem diversos tipos de amostragens probabilísticas. Neste estudo, por serem conhecidas informações sobre a população, decidiu-se pela amostragem estratificada com alocação proporcional. Em geral, quando comparada à amostragem aleatória simples, esse procedimento aumenta a representatividade da amostra e reduz o erro amostral.

Nesse tipo de delineamento, os indivíduos da população foram divididos em subgrupos disjuntos, formados por indivíduos relativamente homogêneos. As variáveis que definiram os estratos são: Região $\left(1^{\mathrm{a}}, 2^{\mathrm{a}}, 3^{\mathrm{a}}, 4^{\mathrm{a}}\right.$ ou $5^{\mathrm{a}}$ ), Lotação (Vara JEF, Vara JEF Adjunto ou Turma Recursal) e Titularidade (Titular ou Substituto). A alocação proporcional garantiu que, para cada estrato, o tamanho da amostra fosse proporcional ao tamanho da população.

O tamanho da amostra foi calculado com o objetivo de estimar a média do nível de propensão ao compartilhamento de conhecimento tácito pelos juízes, de tal forma que se tenha $95 \%$ de nível de confiança e uma margem de erro absoluto de 0,5 pontos. Considerou-se uma taxa de não resposta de $10 \%$.

O Apêndice B resume o tamanho da amostra por estrato e o Apêndice C apresenta a lista dos 106 juízes selecionados aleatoriamente, segundo técnicas estatísticas. Posteriormente, um dos juízes foi descartado da amostra por não pertencer aos JEF.

Depois de aproximadamente 12 meses de contatos com os juízes, o pesquisador decidiu, em comum acordo com a empresa de Estatística, encerrar a pesquisa com 95 respondentes de uma amostra de 105. A redução não comprometeu a amostra, uma vez que já estava previsto um percentual de não respondentes.

Cabe, no entanto, a observação de que nem todos os 95 respondentes responderam todas as questões. Esse decréscimo não interferiu, contudo, na identificação das variáveis 
explicativas (VE), pois o modelo de regressão Beta (reduzido), utilizado para selecionar as VE, tem por natureza extrair somente as variáveis significativas.

Os questionários ficaram à disposição dos juízes no período de junho de 2014 a abril de 2015. Essa expansão temporal deve-se ao fato de ser muito escasso o tempo dos juízes federais. Em alguns casos foram necessários vários contatos telefônicos ou pessoais para se obter um único preenchimento.

\subsection{CLASSIFICAÇÃO DA PESQUISA}

A pesquisa é descritiva quando relata as características dos sujeitos da amostra, identificando possibilidades de relação e correlação entre variáveis, e explicativa quando se prestou a apontar as variáveis tidas como possíveis de impactação no fenômeno (GIL, 2010).

É teórica, pois apresenta uma novidade ao campo científico (PARRA FILHO, 1998), qual seja, o método que introduz uma nova unidade de medida (anyi). Aplicada, ao visar a uma aplicação prática (PARRA FILHO, 1998; MORESI, 2004) e ao se propor a definir um método para intervenção no contexto vivencial dos sujeitos estudados (BARROS; LEHFELD, 1990).

Com o propósito de estabelecer uma correlação entre as variáveis, por meio da captura de dados a partir das respostas dos indivíduos da amostra, o estudo ressalta ainda aspectos distintivos de uma pesquisa de campo (PARRA FILHO, 1998).

Quantitativa, ao se verificar qual a relação entre variáveis (TEIXEIRA, 2012) e medir atitudes, opiniões e preferências; determinar o perfil de um grupo, baseando-se em características comuns; e por meio de técnicas estatísticas, criar um modelo capaz de predizer comportamentos (MORESI, 2004). Esse caráter quantitativo fica também demonstrado quando, além da construção das variáveis numéricas e do indicador, propôs o estudo uma unidade de medida e valores individuais para cada juiz, ambos relacionados à propensão ao ato de compartilhar.

\subsubsection{A fase descritiva}

A pesquisa descreveu as características da amostra e identificou possíveis relações entre variáveis (GIL, 2010). Analisou as características do fenômeno, com isolamento de 
variáveis principais (LAKATOS, 2010) e descreveu o objeto por meio de levantamento de dados, com busca de indicadores e elaboração de perfis (BARROS, 1990).

Gil (2010) aponta vantagens e desvantagens desse tipo de pesquisa:

Principais vantagens:

a) Conhecimento direto da realidade: com base nas informações provenientes dos próprios sujeitos (comportamento, crenças, opiniões), isenta-se o estudo de um maior subjetivismo do pesquisador;

b) Economia: quando o instrumento de coleta utilizado é um questionário, os custos tornam-se relativamente menos onerosos;

c) Quantificação: os dados levantados propiciam uma análise estatística. As variáveis, ao serem quantificadas, permitem o emprego de correlação e outros procedimentos estatísticos, como aplicação de margem de erro.

Desvantagens:

a) Ênfase nos aspectos perceptivos: ao recolherem-se os dados e as informações relativos à percepção que os sujeitos guardam de si próprios, pode ocorrer certa subjetividade. Para mitigar tal efeito, foram suprimidas questões que possivelmente os juízes não responderiam.

b) Pouca profundidade no estudo da estrutura e dos processos sociais: a profundidade do estudo fica restrita às variáveis de natureza interpessoal e institucional determinadas pelos sujeitos que compuseram a amostra e pela atmosfera institucional (normas, políticas, modelos de gestão e estilo das autoridades de comando).

c) Limitada apreensão do processo de mudança: o levantamento, ao coletar os dados e as informações dos indivíduos estudados em determinado momento, registra um 'instante' da ocorrência do fenômeno, atribuindo à pesquisa um caráter estático.

Um possível aumento de profundidade, bem como, uma maior amplitude de captura das mudanças requereria um acompanhamento dos sujeitos da mesma amostra por certo período de tempo, com o fim de perceber mudanças de julgamento pessoal e interferências motivadas pela alteração do ambiente institucional. Apesar dessa limitação, assinala Gil (2010, p. 36) que "o levantamento possibilita a obtenção de grande quantidade de dados a respeito dos indivíduos". 
O método empregado para a pesquisa foi o 'levantamento', adequado para estudos descritivos (GIL, 2010). Este método tem por característica recolher informações de todos os sujeitos participantes do universo pesquisado.

Dada à exiguidade de tempo dos juízes e pelo grau de dificuldade material que envolve um censo, optou-se pela seleção, mediante procedimentos estatísticos, de uma amostra significativa de todo a população tomada como objeto da investigação. As conclusões, no entanto, são projetadas para a população, conforme a margem de erro determinada pelos cálculos estatísticos.

Os levantamentos por amostragem gozam hoje de grande popularidade entre os pesquisadores sociais, a ponto de muitas pessoas chegarem mesmo a considerar pesquisa e levantamento social a mesma coisa (GIL, 2010, p. 35-36).

Enquanto descritiva, executou o levantamento de características de uma amostra de juízes federais de JEF; identificou correlação entre variáveis; permitiu aplicação de técnicas estatísticas (análise de dispersão, Análise de Componente Principal (ACP), modelo Beta e Beta Reduzido); identificou oito variáveis explicativas e apresentou um indicador, como variável-chave, além de ter elaborado um perfil dos juízes pesquisados quanto à propensão ao compartilhamento.

\subsubsection{A fase explicativa}

O estudo tratou da identificação das variáveis que explicaram o compartilhamento. Uma vez apontadas as variáveis explicativas, em número de oito, análises foram realizadas no sentido de elucidar o significado dos resultados alcançados, bem como abrir portas para novas hipóteses e pesquisas futuras.

O método indicado para recolher os dados e as informações, segundo Gil (2010) foi o levantamento de campo (survey). A coleta permitiu explicar o fenômeno (RUDIO, 1986), ou seja, de que modo o comportamento dos sujeitos amostrais, os juízes federais de JEF, dentro da sua propensão em compartilhar, está associado às variáveis que explicaram esse comportamento e, por conseguinte, o fenômeno do compartilhamento do conhecimento tácito.

\subsection{O MÉTODO PARA IDENTIFICAR AS VARIÁVEIS EXPLICATIVAS DO COMPARTILHAMENTO DO CONHECIMENTO TÁCITO}

Em nenhum caso o método pode estabelecer a sua verdade, ainda que seja verdadeira, pois o número de teorias possivelmente verdadeiras continua infinito, a qualquer tempo a após qualquer número de testes cruciais. (POPPER, 1999, p. 25). 
O método para se identificar as variáveis que explicaram o compartilhamento do conhecimento tácito foi detalhado em etapas e estágios.

A etapa 1 tratou da identificação do agente central da estrutura a ser estudada. Quando aplicada aos JEF, a pesquisa tomou o juiz federal como a figura principal que emprestou a sua percepção e informou em que níveis mantinha interação com determinados grupos de pessoas que a pesquisa tratou por Rede de Compartilhamento (RC).

Na etapa 2, com suporte da literatura e da experiência do pesquisador, foi estabelecida essa rede. Somadas, essas duas etapas atenderam ao Objetivo Específico $\mathrm{n}^{\mathrm{o}} 1$ - Analisar $o$ processo de compartilhamento do conhecimento tácito segundo a literatura.

A etapa 3 acolheu o Objetivo Específico 2 - Mapear as possíveis variáveis associadas ao compartilhamento do conhecimento tácito entre os juízes do JEF. Variáveis foram instituídas e as hipóteses organizadas de forma a trazer possíveis explicações sobre o fenômeno do compartilhamento do conhecimento tácito.

A etapa 4 marcou o início das etapas relacionadas ao Objetivo Específico 3 Identificar as variáveis que explicam o fenômeno do compartilhamento do conhecimento tácito dentre as variáveis possíveis mapeadas que envolveu a criação de uma unidade de medida de cunho numérico, tratada por indicador, capaz de, segundo a percepção dos juízes de JEF: a) avaliar o impacto trazido por cada variável prevista nas hipóteses (VH) sobre a propensão dos juízes em compartilhar; e b) mensurar um valor numérico individual para a propensão dos juízes em compartilhar seus conhecimentos tácitos. Esta etapa foi dividida em quatro estágios e envolve procedimentos estatísticos destinados à criação do indicador.

A etapa 5 apresentou outras técnicas estatísticas utilizadas para a aferição dos impactos das variáveis sobre o indicador e a identificação das variáveis explicativas.

\subsubsection{Etapa 1 - Identificação do agente central}

Esta etapa requereu que se definisse qual figura da estrutura organizacional pudesse emprestar suas percepções acerca do fenômeno do compartilhamento do conhecimento tácito. Sveiby (1997) destaca a existência de determinados profissionais na organização que reúnem capacidade de tomar uma decisão de impacto relevante.

O volume de conhecimento envolvido nos processos de trabalho requer um profissional que possa, simultaneamente, usá-lo, interpretá-lo e gerenciá-lo (REZENDE, 
2002; EDVINSSON; MALONE, 1999), desempenhando um papel coletivo dentro de uma ação sistêmica (MIRANDA; SIMEAO, 2004).

O agente central é o indivíduo que tem condições de propor uma perspectiva comunitária com responsabilidade social, buscando atender mais a demandas de determinada comunidade (interna ou externa) e menos a suas próprias necessidades (BROHM; HUYSMAN, 2003).

Nos JEF, o juiz ocupa essa posição central. Tal escolha encontra guarida no estudo de Ruschel (2012, p. 131), “O juiz é o elemento principal do processo do judiciário, pois todos os demais agentes se integram ao juiz" e no trabalho de Korhonen (2014) que concebe o agente central no indivíduo que se torna uma autoridade especialista, cujo ativo intangível está intrinsecamente relacionado à sua pessoa e executa ações de transformação da realidade.

Por ser autoridade especialista no saber julgar, a atividade judicante leva à produção de um largo volume de conhecimento (jurisprudência), "caracterizada como uma espécie de saber organizacional, oriundo [contudo] do saber individual de cada julgador" (MARTINS; LIMA; PESSANHA, 2005, p. 20).

O juiz revelou-se importante e a partir dele, de suas perspectivas e por meio de questionamentos a ele dirigidos a pesquisa se desenvolveu.

De acordo com suas respostas, variáveis foram construídas com o fim de mensurar a propensão ao compartilhamento de conhecimento. Lotados em Varas JEF, Varas JEF Adjunto e Turmas Recursais, foram sujeitos do estudo 95 juízes.

Como jurista $^{50}$, o juiz deve ser aquele que "enxerga além dos códigos, não se contentando em saber o que dispõem as leis" (GUSMÃO, 1998, p. 4). Essa capacidade permite-lhe servir como intermediário de inovação, um duto do conhecimento tácito, quando, conhecendo as necessidades de conhecimento (jurisprudências, súmulas, acórdãos, entendimentos, provas), é capaz de construir uma nova ligação, um rito mais aprimorado, entre a demanda dos jurisdicionados e dos seus advogados e a oferta de decisões. Este posicionamento permite a fluência dos conhecimentos tácitos necessários ou as "concepções próprias de sua mente" (OLIVEIRA, 2009, p. 2), não somente para a formação do juízo e produção de decisões e sentenças eficazes, mas também para a elaboração de modelos (mentais ou físicos) capazes de trazer soluções melhores a todo o sistema judicial.

O “juiz é o agente-chave no processo de inovação do Judiciário. É a pessoa que tem por mister, simultaneamente, dirigir, deliberar e julgar em nome do Estado" (SILVA, 2008,

\footnotetext{
${ }^{50} \mathrm{Na}$ acepção que indica a pessoa dedicada ao Direito, o escritor jurídico (SILVA, 2008, p. 809), aproveitada
} em sentido amplo, quando se leva em conta o juiz como produtor de decisões. 
p.18 $)^{51}$. Os juízes são capazes até de influenciar a criação de novas estruturas no Judiciário nacional $^{52}$.

Em pesquisa realizada pelo Conselho da Justiça Federal, no ano de 2000, $87 \%$ dos juízes federais ouvidos manifestaram-se favoráveis à criação dos juizados especiais federais (BRASIL, 2000, p. 40).

Enquanto agente social ativo que interfere e totaliza o contexto organizacional (FERRAROTTI, 1991), o juiz dos JEF como indivíduo imprime seu padrão pessoal ao fenômeno (NONAKA; TAKEUCHI, 1997; SMITH; MCKEEN; SINGH, 2007) e confere mudanças às práticas de trabalho e ao ambiente institucional. As práticas quando compartilhadas podem levar ao aperfeiçoamento de indivíduos que por sua vez levam as organizações a melhores patamares de desempenho (HSU, 2008).

No tocante às boas práticas, o juiz pode ser aquele que as alavanca quando cria ou reusa o conhecimento tácito (SZULANSKI, 2003), concentrado na mente do outro juiz, dos servidores, lotados em sua Vara ou não, bem como dos ASJ. As práticas que comumente referem-se às rotinas críticas (de julgamento) estão no centro das decisões organizacionais e tornam-se parte do aprimoramento dos JEF.

$\mathrm{Na}$ Vara, há um intenso processo comunicativo. Diversos conhecimentos são transacionados e o juiz aparece como um 'regulador' desse processo. Assim, não seria forçoso concebê-lo um knowledge broker (GODFREY; FUNKE; MBIZVO, 2010), ou seja, um agente que, em nome da Justiça e do Direito, permite a transação do conhecimento, sua avaliação e reavaliação, buscando em cada caso, mesmo sem qualquer remuneração decorrente desse 'negócio', o melhor para todas as partes.

Chamados de "Luteros", deles é exigida a "grande reforma da cultura e dos métodos de trabalho que ainda contaminam a justiça brasileira [pois] não existe coisa pior neste mundo do que justiça tardia” (REIS, 2003. p. 30-31).

Considerados distantes da realidade (até mesmo incentivados a isso), “o juiz deve ser afastado de todo vínculo humano, superior a qualquer simpatia e a qualquer amizade; e é bom que os réus o sintam distante e estranho, inacessível como uma divindade em seu empíreo"53 (CALAMANDREI, 1995, p. 46) e ao mesmo tempo incitados a participar do convívio social,

o juiz não é um herói. Não é conhecido como "amigo do povo". Muitos cidadãos até o consideram fugitivo do contrato social por temor à contaminação. A fobia de ser acusado de parcial, suscetível de se influenciar ou de ser pressionado a julgar deste

\footnotetext{
${ }^{51}$ Silva (2008), consoante a jurisdição e a competência do juiz, atribui a ele ainda 44 outras denominações!

52 A criação dos JEF, pela Lei 10.259, de 12 de julho de 2001, deu-se no ano seguinte da consulta a juízes federais.

${ }^{53} \mathrm{Na}$ mitologia grega, morada dos deuses.
} 
ou daquele modo tende a torná-lo um anacoreta social. Ser distanciado das questões triviais, sobrepairante imune às fraquezas terrenas. O solitário tende à patologia. Ao se privar do convívio, o julgador pode perder a capacidade de se inteirar das aflições dos semelhantes. Não é incomum assoberbar-se e se converter num arrogante infeliz. (NALINI, 2008, p. 43).

É também o juiz o "arquiteto" dos conhecimentos que alteram as rotinas e compõem a decisão. Dessa forma, o magistrado atua como gatekeeper $^{54}$ e líder de inovação, criando e recombinando, para a melhoria dos serviços, "sistemas simples, rotinas, hábitos, que possam ajudá-lo, e ao seu pessoal, na tarefa de receber, armazenar e filtrar novas ideias, tudo como parte integrante e automática do seu trabalho diário" (MILLER; WEDELLWEDELLSBORG, 2013, p. 23).

A pessoa do juiz, permeável (ou não) à entrada e à saída de conhecimentos tácitos, pode, em caso de compartilhamento, permitir uma renovação benéfica de saber. Sobre as lacunas do conhecimento ou entre o pleito e a sentença, o compartilhamento lança pontes que podem mitigar o efeito da imobilidade do conhecimento tácito (YAKHLEF, 2005).

O juiz também tem a responsabilidade de um harmonizador. Choo (2003) adverte da importância em se impedir rotinas muito rígidas que possam bloquear a criatividade e prejudicar a flexibilidade dos fluxos de trabalho. Marsick (2009) pontua que a harmonia gerencial propicia um ambiente de aprendizagem informal que incentiva rápidas transferências de práticas e conhecimento.

Santos (2005) ao destacar o desempenho de juízes estaduais assinala a importância do compartilhamento de conhecimento "Eu acho que faltaram mais juízes irem lá e passarem as suas experiências, entendeu?" (SANTOS; CASTILHO; KILIMNIK, 2005, p. $11^{55}$ ).

Esse compartilhamento parece também ser vivenciado por juízes de JEF quando se veem obrigados a acumular funções administrativas (Diretores de Foro, Juízes Coordenadores de JEF nas Seccionais, entre outras) ou passam a atuar como repositórios pluridisciplinares (ZAFFARONI, 1995). Nesse caso, precisam integrar um considerável volume de conhecimento relacionado aos saberes jurisdicional (cível, criminal, ambiental,

\footnotetext{
54 Termo criado pelo cientista social Kurt Lewin. White, autor do capítulo de onde a referência foi retirada (WHITE, D. M. The "Gate Keeper": A case study in the selection of news - chap. 5 in BERKOWITZ, D. Social meanings of news: a text-reader. Thousand Oaks, California: Sage Publications, Inc., 1997) coloca que Lewin, em seu último artigo antes de falecer, Journalism Quarterly, 1950, v. 27, p. 383-396, sustenta que veículos de massa são como 'gates', governados por regras imparciais ou por 'gate keepers' (indivíduos ou grupos) que empoderados decidem o que "entra" e o que "não entra" na programação.

${ }^{55}$ No trabalho de Santos, esse depoimento refere-se ao Entrevistado n. ${ }^{\circ} 8$.
} 
previdenciário, entre outros), administrativo ${ }^{56}$, até mesmo médico ou de assistência social quando examina questões relacionadas a determinadas perícias.

Como gestor desincumbe-se de assumir atividades relacionadas ao planejamento estratégico, gestão de projetos, inovação de processos, organização de fluxos de trabalho, controle de serviços de seu gabinete e de sua Vara (a despeito de contar com um diretor de Secretaria), administração de tempo, delegação de funções, avaliação de serviços e gestão de pessoas (LOPES, 2009; SOUZA, 2012).

Por fim, sem, no entanto, exaurir o tema, o juiz apresenta-se como líder, quando, ao ir além do ato de prolatar decisões, colabora com seus servidores, coordena os trabalhos e mantém motivada a sua equipe (PORT, 2012).

\subsubsection{Etapa 2 - Explicitação da rede de compartilhamento (RC)}

Reconhecido o agente central, verificou-se quão importante era identificar com quais pessoas pertencentes a sua estrutura de trabalho ele/ela compartilhava conhecimento.

Levou-se em consideração inicialmente que, para ocorrer transferência de conhecimento, certo nível de confiança deve haver entre os parceiros (BECERRA; LUNNAN; HUEMER, 2008) e que a capacidade de o agente central aprimorar o seu conhecimento pode estar atrelada a uma habilidade de lidar com o conhecimento de outros, isto é, requer interatividade de um conjunto de conhecimentos (GRANT, 2011). Esse posicionamento também é encontrado na obra de Leonard e Sensiper (1998) quando apontaram que os processos baseados em troca e acúmulo de conhecimento raramente são empreendimentos individuais.

Sveiby (1997) chama a atenção para o modo como o conhecimento se apresenta e flui. Ao definir 'rede social', evidencia a sua constituição a partir de relacionamentos pessoais em determinado ambiente; o que Nonaka e Takeuchi (1997) trataram por socialização desenvolvida no espaço $\mathrm{Ba}$ (NONAKA; KONNO, 1998) que (grosseiramente traduzido do Japonês) significa 'local'.

Plataforma chave para a criação do conhecimento, o $B a$ foi considerado pelos autores como um espaço de compartilhamento que serve para provocar a geração do conhecimento, bem como, aquisição e troca de conhecimento. Pode ainda ser capaz de confluir

\footnotetext{
56 O Anexo A apresenta a cópia de uma Portaria da $4^{\mathrm{a}}$ Região onde se pode observar a quantidade de conhecimentos administrativos que o juiz deve absorver quando na função de Diretor do Foro.
} 
conhecimentos tácitos entre diferentes atores sociais, saberes, visões de mundo, na busca da concretização de objetivos organizacionais ou individuais (LOUREIRO, 2002).

As interações que se dão sob a forma de encontros e debates informais (conversas) e formais (eventos de natureza interativa, como seminários, congressos) são em sua essência $B a$ onde são promovidos movimentos do conhecimento tácito caracterizado pelo compartilhamento. Pessoas e organizações, ao permitirem trânsito a seus conhecimentos tácitos, possibilitam transformações de conteúdos mentais, surgimento de novas ideias, inovação e melhor desempenho organizacional (LEMOS, 2000; SHOUKAT, 2012).

Dentre os subespaços que compõe o $B a$, há um específico para o conhecimento tácito, Originating $B a$, conforme a figura 7, que cria atmosfera à socialização e permite o movimento social de experiências e modelos mentais. Este espaço tem por propósito promover a remoção de barreiras entre o indivíduo e os outros membros da organização. Dele, "emerge cuidado, amor, confiança e compromisso" (NONAKA; KONNO, 1998, p. 46). Na visão dos autores, o conhecimento tácito é o fundamento do conhecimento e propicia sua criação e acúmulo em nível individual.

Figura 7 - As quatro características do Ba

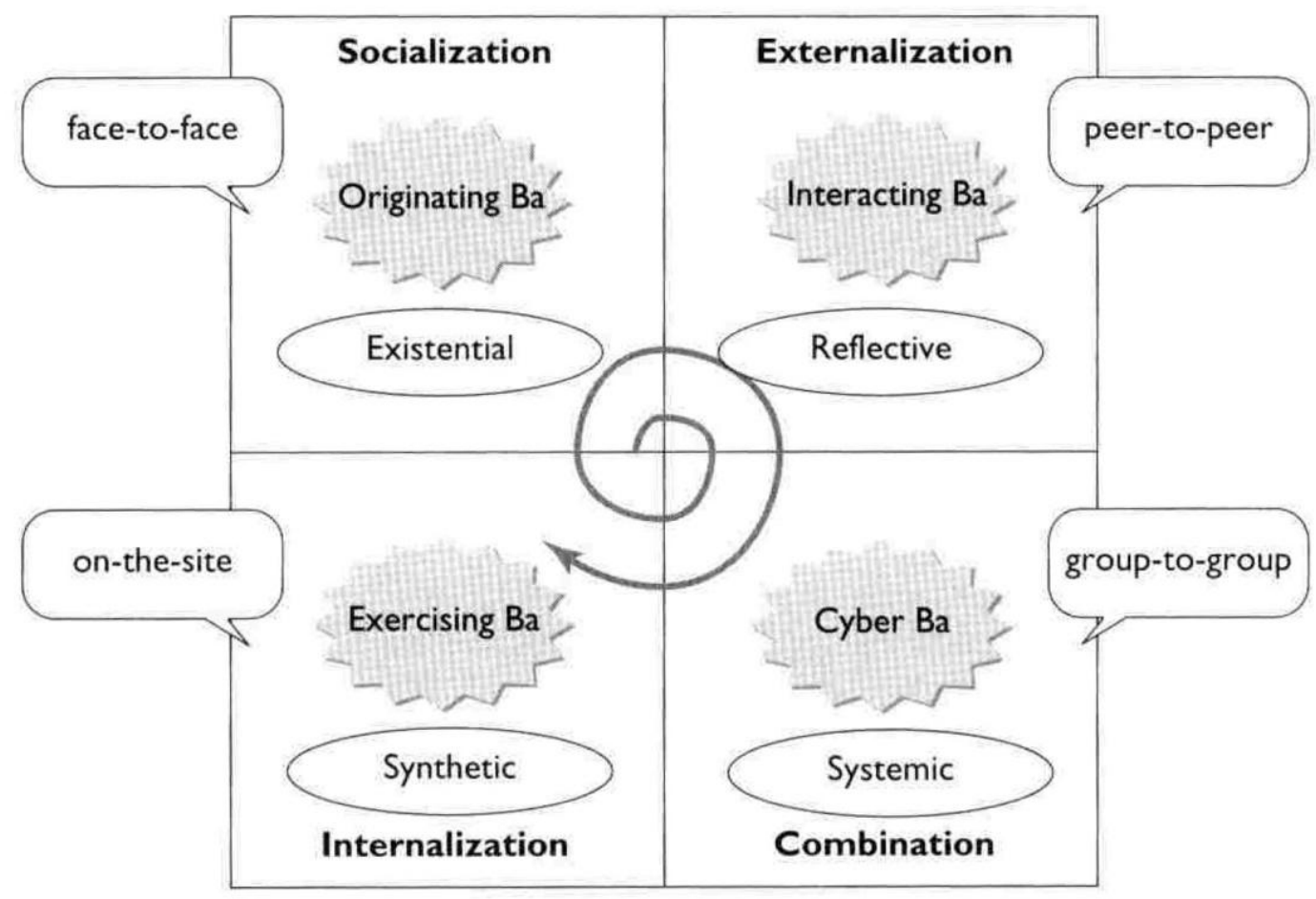

Fonte: Nonaka e Konno (1998, p. 46).

$\mathrm{Na}$ transferência de conhecimento, a intensidade dos laços (fortes/fracos) entre fonte e receptor depende da qualidade do relacionamento e da natureza do conhecimento (tácito ou explícito) a ser compartilhado (JASIMUDDIN, 2007 apud PETRIN, 2015) e aumentam 
conforme a frequência da comunicação e da interação (ARGOTE et al., 2003 apud PETRIN, 2015).

Pela perspectiva de rede, Borgatti e Li (2009) visualizaram qualquer sistema como um conjunto de nós e atores inter-relacionados. Desenvolveram uma tipologia de laços (figura 8) entre diversos tipos de grupos. O primeiro nível separa os laços em Contínuos, laços que estão continuamente ligados, como esposo e esposa, e em Discretos, laços baseados em eventos $\operatorname{discretos}^{57}$, número de vezes que o indivíduo A envia email ao indivíduo B.

\section{Figura 8 - Tipos de laços}

\section{Types of Tie}

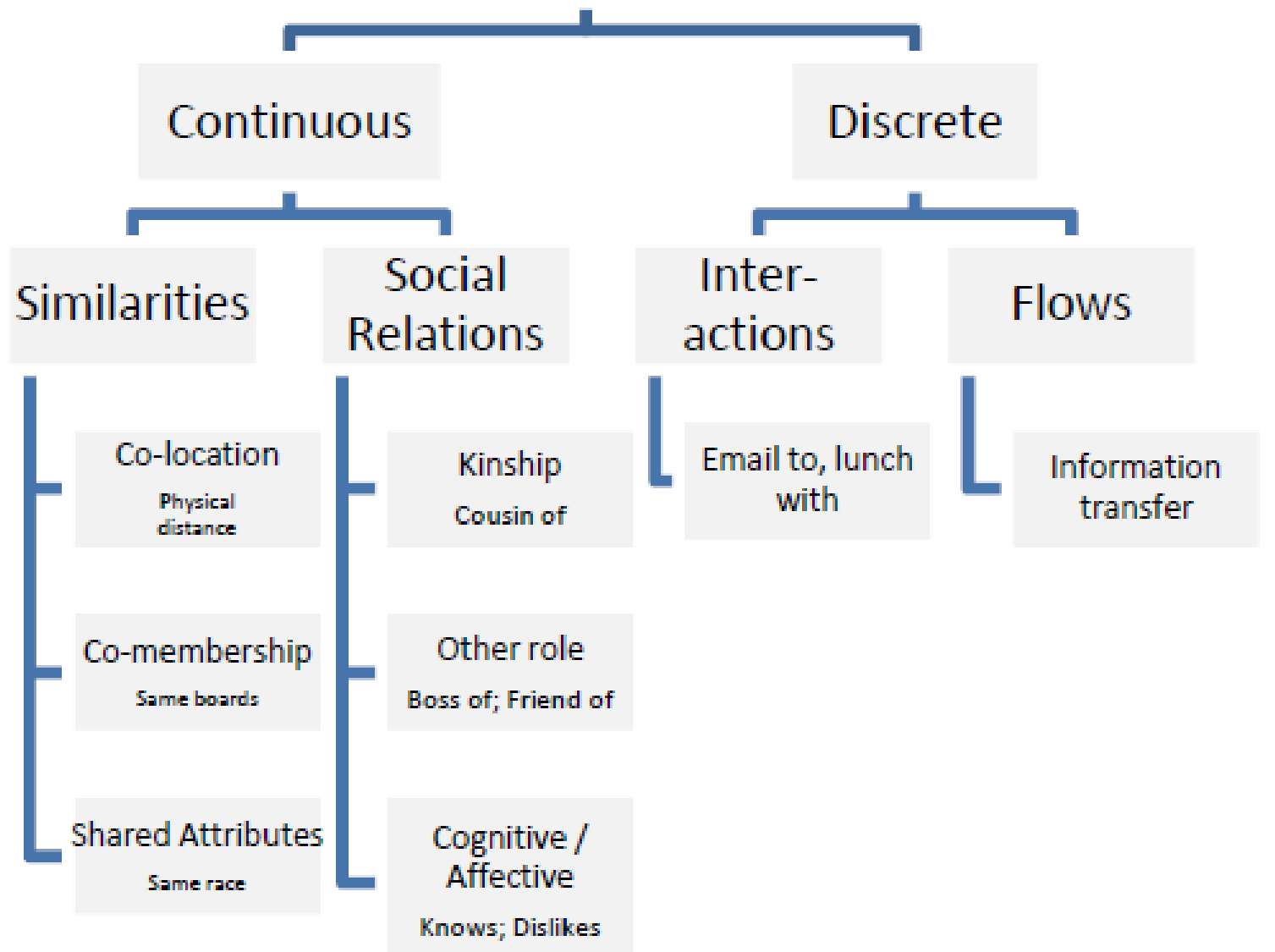

Fonte: Borgatti e Li (2009, p. 3).

A segunda camada de níveis revela quatro grupos de laços, provenientes, dois a dois, de cada tipo do primeiro nível. Na bipartição do tipo Contínuos, são apresentadas as classes:

${ }^{57}$ Em evento contínuo, o fenômeno pode ocorrer em qualquer instante de tempo. Em um evento discreto, considera-se a ocorrência de um fenômeno apenas em determinados instantes de tempo dentro de um período, verifica-se o fenômeno a cada intervalo de 5 minutos, por exemplo (CHANIN et. al, 2005). 
- similaridades que representa relacionamentos interpessoais que os autores consideraram "pré-sociais” e classificaram em Co-localização (Co-location), levando em consideração a distância física; Co-membro (Co-membership), pertencentes aos mesmos quadros e Atributos Compartilhados (Shared Attributes), relativos à raça;

- relações sociais que foi subdividida em Parentesco (Kinship); Outros Papéis (Other Role), "chefe de...", "amigo de ..."; e Cognitivo-afetivo (Cognitiveaffective), quando apresentavam gostos e desprazeres semelhantes.

As classes vizinhas, Interações (Interactions) e Fluxos (Flows) pertencem ao tipo Discreto.

No que diz respeito ao compartilhamento de conhecimento tácito nos JEF, depreendeu-se, a partir de Borgatti e Li (2009) que o fenômeno ocorre de forma contínua e cada relacionamento (com pares, com ASJ e com servidores) segue um laço distinto.

No estabelecimento da RC, consideraram-se quais indivíduos ou grupos mantinham com o juiz maior frequência de comunicação. Foi proposto que o compartilhamento fosse avaliado segundo a frequência de interação do agente central (AC) com: os seus pares; com agentes externos (AE) e com a sua própria equipe de trabalho. Esse arranjo social foi tratado por Rede de Compartilhamento, conforme a figura 9.

Figura 9 - Rede de Compartilhamento (teórica).

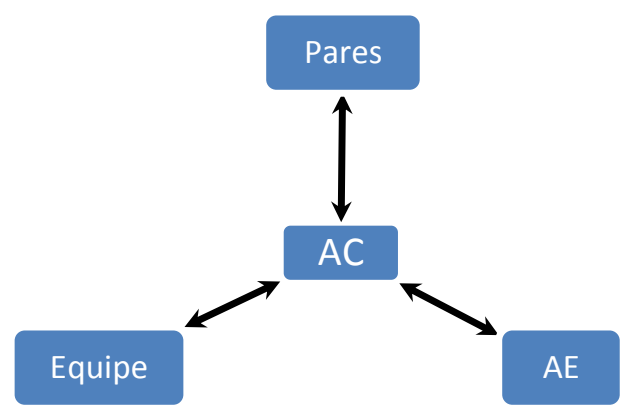

Fonte: Do autor.

A interação entre os membros dessa rede se dá nas duas direções, do centro para as extremidades e das extremidades para o centro. O profissional atua como nó da rede. Redes que interligam pessoas cuja experiência e preparo facilitam o trabalho com o formato tácito de conhecimento, são facilitadores da execução dos serviços (SILVA, 2004).

Mesmo ciente de que é menos comum a troca externa de conhecimento tácito (FETTERHOFF; NILA; MCNAMEE, 2011), firmou-se a presença dos ASJ na RC com base no entendimento de que: 
a) as fontes de conhecimento necessárias às atividades da organização podem estar dentro ou fora da organização (LEMOS, 2000);

b) os bens intangíveis relevantes para a organização, os "ativos de mercado" (fornecedores, entes cooperativos ou alianças estratégicas), são parte do negócio (REZENDE, 2002); e

c) os fornecedores, consultores, parceiros de outras empresas, pesquisadores funcionam como "recursos do entorno", apesar de externos à organização, influenciam nos resultados. (PENROSE, 2006, p. 15).

Para análise do laço juiz-equipe, o modelo de Lytras e Pouloudi (2006) - figura 10 contribuiu para que também fosse avaliada, na relação social de compartilhamento de conhecimento tácito, a interação do indivíduo com equipes de trabalho.

Os autores destacaram dois tipos principais de atores integrantes do fluxo de conhecimento, (1) a pessoa que carrega experiências, habilidades, conhecimento e cognição e capacidade de aprendizagem; e (2) o grupo, a equipe, o time, que utiliza a sinergia dessa rede para atingir os objetivos da organização. Assinalaram, contudo, que esse fluxo dinâmico de conhecimento raramente acontece de forma explícita. 
Figura 10 - Fluxo dinâmico em organizações intensivas em conhecimento ${ }^{58}$

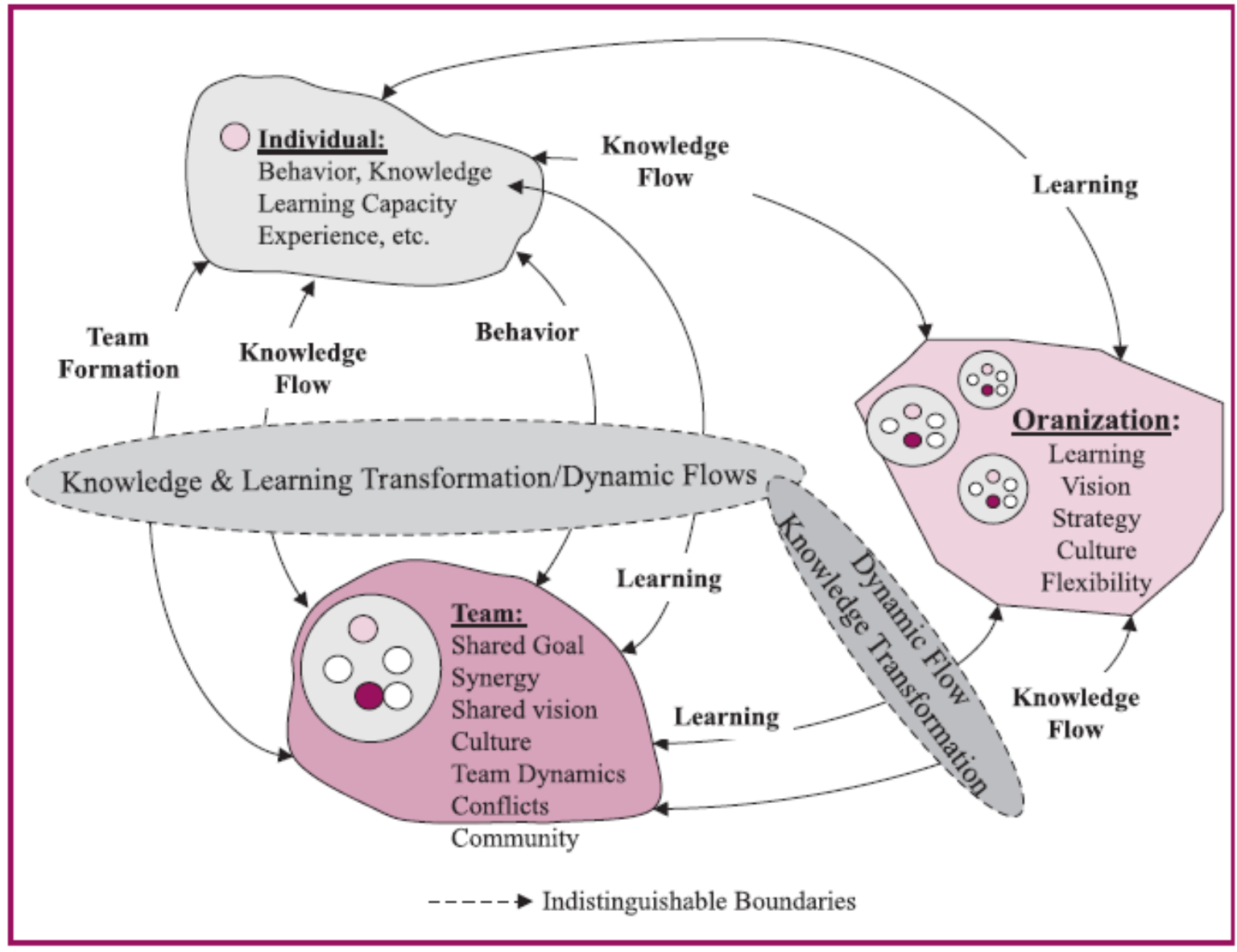

Fonte: Lytras e Pouloudi (2006, p. 69).

A dinâmica do trabalho conjunto do indivíduo com sua equipe cria um ambiente contextual onde se desenvolve e acontece o fluxo de conhecimento. Esse fluxo pode ser tido como um mecanismo de transformação organizacional baseado em conhecimento.

A "capacidade de conhecimento" "59 de cada indivíduo, dentro do grupo ou fora dele, atua em prol de um constante compartilhamento sujeito-ambiente, sujeito-sujeito e sujeitoequipe.

Nos JEF, cercam-se os juízes de suas equipes de trabalho, assessorias e secretarias que contribuem com seu conhecimento tácito de forma individual ou coletiva para a elaboração das decisões e sentenças.

Traçando um paralelo com a RC teórica (Figura 9) com os laços percebidos nos JEF, tem-se: como agente central (AC), o juiz; como seus pares, outros juízes; como agentes externos, os ASJ; e como sua equipe, os servidores, conforme demonstra a figura 11.

\footnotetext{
${ }^{58}$ No original knowledge-intensive organization.

${ }^{59}$ No original, knowledge capacity.
} 
Figura 11 - Rede de Compartilhamento aplicada aos JEF.

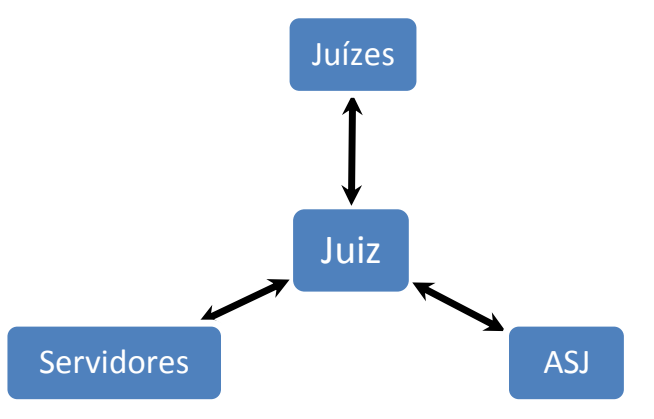

Fonte: Do autor.

Na constituição da RC e na análise dos laços interativos, levou-se em consideração:

1) a importância da avaliação da frequência de contato entre os juízes e seus pares, dada as similaridades que apresentam por pertencerem ao mesmo quadro e dividirem o mesmo local de trabalho (BORGATTI; LI, 2009).

2) O vínculo que se enxergou na figura do agente externo (ASJ) foi resultado de uma análise que considerou se havia e quem eram os principais sujeitos do processo de construção do conhecimento coletivo encontrados fora dos limites do Judiciário, pois, segundo Patokorpi (2006), peritos externos que possuem o conhecimento tácito relacionado às necessidades profissionais internas fazem parte da solução.

\subsubsection{Etapa 3 - Mapeamento das possíveis dimensões e das variáveis explicativas, estabelecimento das hipóteses e elaboração do instrumento de coleta de dados e informações}

Esta etapa visa a atender ao Objetivo Específico 2 - Mapear as possíveis variáveis associadas ao compartilhamento do conhecimento tácito entre os juízes do JEF;

O mapeamento foi concebido a partir de três fontes:

1) a revisão da literatura;

2) as contribuições trazidas pelos juízes, desembargadores e os membros da rede de compartilhamento $^{60}$; e

3) o comparecimento a eventos que propiciaram a oportunidade de mesclar ideias relacionadas ao conhecimento tácito e ao Judiciário. Eventos esses, todos de natureza presencial:

\footnotetext{
${ }^{60}$ Os contatos deram-se pessoalmente e por meio de ligações telefônicas e emails.
} 
a) CNJ - Justiça em Números, quando foi apresentado um trabalho conjunto do autor com a sua Orientadora em forma de pôster, com o título "Inteligência Organizacional Aplicada ao Aprimoramento da Gestão Judiciária” (Brasília-DF CNJ - 29 e 30 de outubro de 2012). (BRASIL, 2012);

b) V Seminário Justiça em Números (Brasília-DF, Conselho Nacional de Justiça (CNJ), 29 e 30 de outubro de 2012);

c) VIII Workshop Internacional em Ciência da Informação - WICI 2012 (BrasíliaDF, Universidade de Brasília (UnB), 07 a 09 de novembro de 2012);

d) $10^{\circ}$ Workshop Brasileiro de Inteligência Competitiva e Gestão do Conhecimento (Brasília-DF, IBICT, 19 a 21 de novembro de 2012);

e) Seminário Juizados Especiais: diagnósticos e perspectivas (Brasília-DF, Conselho Nacional de Justiça (CNJ), 11 de março de 2013);

f) Seminário Atualidade e Futuro da Administração da Justiça (Porto Alegre-RS, TRF4, 11 e 12 de março de 2013);

g) Projeto MELHORAÇÃO, quando juízes reuniram-se para apresentar e discutir boas práticas (Brasília-DF - TRF1 - 29 e 30 de agosto de 2013) e, em um segundo momento, avaliar os resultados (10 e 11 de abril de 2014), dando oportunidade em ambas as ocasiões, ao intercâmbio de experiências entre juízes; Oficina do Ministério da Justiça - Indicadores de Acesso à Justiça (Brasília-DF - MJ - 19 de maio de 2014).

A partir do mapeamento, foram elaboradas as hipóteses e simultaneamente o instrumento de coleta que seria aplicado para a obtenção dos dados e das informações necessárias à validação das hipóteses e ao alcance dos objetivos.

Como o método foi forjado para pesquisa de natureza descritiva-explicativa, utilizouse de um questionário (Apêndice A) para “interrogação direta das pessoas cujo comportamento se desejava conhecer" (GIL, 2010, p. 35).

As perguntas do questionário refletiram dois momentos. O primeiro, referiu-se aos questionamentos relacionados à criação da unidade de medida, pensada para mensurar o grau de interação do juiz com os seus pares, com os agentes externos e com a sua equipe. Tais variáveis foram tratadas na pesquisa por "variáveis interativas" (VInt). Este momento está interligado à primeira parte da hipótese central:

Primeira parte: $O$ compartilhamento do conhecimento tácito, nos JEF, entre o juiz, os seus pares, os agentes externos e a sua equipe de trabalho varia (...) 
O segundo momento trata dos questionamentos aos quais estão relacionadas as supostas variáveis associadas ao compartilhamento e guarda relações com a segunda parte da hipótese central. Essas variáveis foram chamadas de "variáveis hipotéticas (VH)”.

Segunda parte: (...) varia de acordo com as dimensões pessoal, acadêmica, funcional, organizacional, geográfica e social.

No que diz respeito à hipótese central (primeira parte), o juiz foi considerado agente central do processo judiciário. Esta figura guarda relação com o profissional (expert) do modelo de Sveiby que interage para a condução do negócio com várias pessoas e desenvolve naturalmente um fluxo de conhecimento via comunicação interpessoal tácita e inconsciente (SVEIBY, 1997).

A importância em se identificar tais relações fica realçada quando se percebe que uma das estratégias utilizadas pelas organizações na transferência de conhecimento é concentrar-se nas pessoas. O foco está no diálogo que elas estabelecem por meio do qual o conhecimento é compartilhado (LEMOS; JOIA, 2012).

No ambiente de troca social, fluem conversas, olhares, sinais, expressões faciais, pontos de vista, experiências, ideias, lições aprendidas e uma implícita aprendizagem carregada de conhecimento tácito (MARSICK, 2009).

Teixeira Filho (2002) coloca que em torno de 50 a $95 \%$ do compartilhamento de conhecimento acontece por meio de conversas e que o conhecimento tácito é mais bem transmitido quando ocorre por meio de interações presenciais. Acrescenta ainda que, estudos realizados no $\mathrm{MIT}^{61}$ apontam que $80 \%$ das ideias que levam à inovação são resultados de conversas de trabalho.

Gratton e Ghoshal (2002) assinalam que gestores conversam e que tal processo é nuclear para o desenvolvimento de novas ideias, para o compartilhamento das experiências e para o aperfeiçoamento individual e coletivo.

Sobre a forma desse tipo de comunicação, 'conversa', Davenport e Prusak (1999, p. 110) argumentam que apesar de o conteúdo da conversa abranger fatos comuns do dia a dia, como esporte e clima, as pessoas questionam outras sobre o andamento de projetos, permutam ideias e pedem conselhos acerca da resolução de seus problemas. Para os autores, "conversas são trabalho" (grifo do original). Acrescentam, ainda, que onde há conversa, há troca de conhecimento.

\footnotetext{
${ }^{61}$ Massachusetts Institute of Technology.
} 
Gratton e Ghoshal (2002) sustentam que é por meio da conversa que gerentes ensinam e inspiram-se, motivam-se e proveem feedback, planejam e tomam decisões.

Conversas encontram-se no coração de como as organizações desenvolvem novas ideias, compartilham conhecimento e experiências, e aprimoram aprendizagens individual e coletiva (GRATTON; GHOSHAL, 2002, p. 209).

Senge (2006) coloca que o vocábulo ‘diálogo' (em grego dialogos) representa um livre fluir de significados entre pessoas e cria a possibilidade de um esclarecimento que não pode ser alcançado individualmente. Para Van den Brink (2003), o diálogo permite a abordagem de uma questão por vários ângulos, oferece aos participantes a possibilidade de compartilhar conhecimento e de gerar novos insights.

A concepção da Rede de Compartilhamento, no que diz respeito à partilha entre juízes encontrou também base em Taal.

O compartilhamento de conhecimento entre juízes pode ajudar a prevenir contra soluções desviantes em processos similares, bem como, melhorar a qualidade de razões e conteúdos das decisões judiciais (...) por meio do compartilhamento de conhecimento, juízes podem beneficiar-se a partir da expertise, experiência e ideias de outro juiz com o fim de elaborar melhores decisões (TAAL, 2014, p. 1).

Em relação ao compartilhamento entre juízes e os ASJ:

a) o então Presidente do Juizado Especial Federal do Rio Grande do Norte, Jailsom Leandro de Sousa (apud CONGRESSO NACIONAL DOS JUIZADOS ESPECIAIS FEDERAIS, 2003, p. 6 - grifo nosso)

informou, ainda, que priorizou a organização e a sistematização dos procedimentos, o que contribuiu muito para o êxito dos trabalhos.(...). Optou por uma gestão simples, desburocratizada, com ênfase ao diálogo com os procuradores, advogados.

b) Taal, tratando do compartilhamento de conhecimento entre juízes dos Países Baixos, Alemanha e Suíça sustentou que "soluções [decisões e sentenças judiciais] precisam ser construídas baseadas na lei e na interação com os representantes das partes" (TAAL, 2014, p.1).

Em relação ao compartilhamento com os servidores, o mesmo (e então) Presidente do Juizado Especial Federal do Rio Grande do Norte, Jailsom Leandro de Sousa (apud CONGRESSO NACIONAL DOS JUIZADOS ESPECIAIS FEDERAIS, 2003, p. 6) informou que "Internamente, partiu-se para o trato direto com os servidores, com realização de reuniões periódicas, sempre buscando mostrar a realidade dos clientes à linha de frente".

Levando em consideração que "a mensuração nada diz a não ser que possa ser comparada mediante um parâmetro" (SVEIBY, 1997, p. 164) e que deveria haver um modo de medir a eficácia do compartilhamento (VAN DEN BRINK, 2003), buscou-se a possibilidade de mensurar esse compartilhamento por meio de um indicador. 
Para tal foram elaboradas as perguntas $3.1,3.2$ e 3.3 que pretenderam buscar a frequência de interação, isto é, o grau de contato dos juízes com seus pares, com os ASJ e com os servidores e destes com os juízes. Essas três variáveis, tratadas como interativas (VInt) serviram de base à construção do indicador de compartilhamento ${ }^{62}$.

Quadro 10 - Questionamentos relativos à 'Frequência de interação'

\begin{tabular}{|c|l|}
\hline $\begin{array}{c}\text { N. }{ }^{\mathbf{0}} \text { das } \\
\text { perguntas }\end{array}$ & \multicolumn{1}{c|}{ Redação apresentada no questionário } \\
\hline 3.1 & $\begin{array}{l}\text { Como Vossa Excelência considera o grau de intensidade de sua interação com } \\
\text { outros juízes, no que diz respeito ao compartilhamento de ideias, experiências, } \\
\text { expertise, habilidades, know-how, entendimentos jurídicos, modelos mentais e } \\
\text { outros conteúdos mentais (conhecimento tácito)? }\end{array}$ \\
\hline 3.2 & $\begin{array}{l}\text { Em relação a sua interação com os operadores do Direito (advogados, } \\
\text { procuradores, promotores, defensores), em que grau se dá o compartilhamento do } \\
\text { conhecimento tácito? }\end{array}$ \\
\hline 3.3 & $\begin{array}{l}\text { Em relação a sua interação com os servidores de sua Vara, em que nível se dá o } \\
\text { compartilhamento do conhecimento tácito? }\end{array}$ \\
\hline
\end{tabular}

Fonte: Do autor.

Para atender à segunda parte da hipótese central:

(...) varia de acordo com as dimensões pessoal, acadêmica, funcional, organizacional, geográfica e social tais dimensões, em número de seis, Pessoal (P), Acadêmico (A), Funcional (F), Organizacional (O), Geográfico (G) e Social (S) foram distribuídas no questionário (Apêndice A) agrupando as variáveis hipotéticas (VH).

\subsubsection{Dimensão Pessoal}

Alguns trabalhos suportaram a escolha da dimensão Pessoal. Heisig (2009), ao avaliar 160 modelos de Gestão do Conhecimento (GC), apresentou dentre os fatores críticos de sucesso para a GC os fatores humanos.

Da análise dos Recursos e Capacidade $(R \& C)$, realizada por Grant (2011), o fator conhecimento heterogêneo contribuiu para supor que características pessoais, como idade, gênero e grau de formação pudessem determinar maior ou menor compartilhamento.

Para variáveis, adotou-se a sugestão de Parra Filho (1998), Selltiz, Wrightsman e Cook (1987) e Miranda e Moresi (2010) que orientaram colher dados e informações sobre o sujeito do experimento, como gênero, idade e naturalidade.

Dessa forma, definiu-se como parte da hipótese que impactam o compartilhamento:

\footnotetext{
${ }^{62}$ A criação da unidade de medida, o indicador, será detalhada no item 3.4.4.
} 
1) O gênero (variável 'gênero' - pergunta 1.2).

2) A idade (variável 'idade' - pergunta 1.4).

3) A naturalidade (variável 'naturalidade' - pergunta 1.5).

\subsubsection{Dimensão Acadêmica}

Leonard e Sensiper (1998) têm sustentado que o conhecimento tácito está incorporado em habilidades cognitivas. Ngah e Jusoff (2009) colocam que o conhecimento tácito pode ser transferido sob a forma de aprendizagem por meio do aprender-fazendo e aprender-vendo. Parra Filho (1998) coloca o nível cultural como uma boa característica do informante. Selltiz, Wrightsman e Cook (1987) orientam a colherem dados do sujeito da pesquisa, entre eles, do nível educacional. Sveiby (1997) aponta como um dos fatores do índice de "Conhecimento Intelectual" de empresa dinamarquesa a qualificação acadêmica do empregado. Miranda e Moresi (2010) julgaram relevante incluir na análise do perfil de sua amostra, com o fim de avaliar a prática de compartilhamento de boas práticas, a 'formação acadêmica'. Grant (2011) sustentou que tal formação é elemento formador dos recursos humanos e eixo da capacidade gerencial da organização.

Gomes (2005), ao analisar o Tribunal de Justiça do Estado do Rio de Janeiro, realizou para diagnóstico do compartilhamento, um levantamento do grau de escolaridade dos servidores.

Tais aspectos levaram o pesquisador a supor que o nível de formação acadêmica e atividades relacionadas, como ensinar e publicar trabalhos, pudessem guardar relação com o compartilhamento. Assim, impactam o compartilhamento:

1) O grau de formação acadêmica (variável 'formação' - pergunta 1.6).

2) O fato de ser docente (docência) (variável 'docência' - pergunta 1.7).

3) $\mathrm{O}$ fato de ter publicado artigos, livros (variável 'publicação' - pergunta 1.8).

\subsubsection{Dimensão Funcional}

A proposição da dimensão 'Funcional' encontrou suporte no modelo de Lemos (2008) quando, ao apresentar os fatores relevantes à transferência de conhecimento tácito em organizações, indica como importante o fator hierarquia. Assinala que a posição hierárquica que ocupa na instituição pode ser um fator de destaque para a mensuração do compartilhamento pessoal. 
Sveiby (1997) aponta como um dos fatores de avaliação dos bens intangíveis de uma empresa dinamarquesa a antiguidade do funcionário. Miranda e Moresi (2010) inseriram como variável o 'tempo na magistratura' e 'hierarquia'.

Dessa forma, resolveu-se avaliar os tempos de magistratura, seja desde a nomeação, seja o tempo à frente de uma unidade de JEF (Vara ou Turma Recursal). Buscou-se verificar também a influência da titularidade, diferença hierárquica entre juízes titulares e substitutos. Propôs-se então que impactam o compartilhamento:

1) O tempo de juiz na Justiça Federal (variável 'tempo de JF' - pergunta 1.9).

2) A fato de ser juiz titular ou juiz substituto (variável 'titularidade' - pergunta 1.10).

3) O tempo de juiz em JEF (variável 'tempo de JEF' - pergunta 1.11).

\subsubsection{Dimensão Organizacional}

A inclusão desta dimensão adveio:

1) dos estudos patrocinados pelo CJF ao colher entre os juízes federais sugestões para a criação dos JEF. (BRASIL, 2000). Por meio de uma pesquisa de campo, o Conselho buscou a opinião dos juízes com realce em dois aspectos: a necessidade de criação e os critérios que deveriam ser adotados para a organização do sistema. Dentre as respostas oferecidas têm-se:

a) A organização a ser criada deve estar adequada aos fluxos judiciais peculiares aos $\mathrm{JEF}^{63}$;

b) Há necessidade de criação de setores especiais como Contadoria, Gabinetes para Médicos, Psicólogos e Assistentes Sociais, Central de Perícia, Pagamento de Precatórios, área para seminários à comunidade, bem como, o acolhimento de outras unidades do Sistema de Justiça, entre elas, INSS e DPU ${ }^{64}$, ou mesmo instituições beneficentes que aceitem prestações de serviços comunitários impostos judicialmente;

c) Os procedimentos de processos criminais devem ser levados em consideração na criação dos JEF;

\footnotetext{
${ }^{63}$ Até a data da elaboração desta tese, as Varas Adjuntas ainda reservam apenas parte de seu espaço físico e de seus servidores à execução dos processos de JEF.

${ }^{64}$ Com o tempo, mais espaço foi requerido para a atuação dos universitários da área de Direito. Por meio de convênio era oferecida prática aos seus estudantes, desafogando o serviço dos servidores que tratavam de atermar (por a termo) as demandas judiciais.
} 
2) Tonet e Paz (2006), ao apontarem que as dificuldades mais importantes encontradas no compartilhamento referem-se à gestão de aspectos do contexto organizacional. Reconheceu quão relevante para o estabelecimento da dimensão 'Organizacional' a sugestão dos autores quanto à "localização de fontes aptas e disponíveis para repassarem conhecimento" (TONET; PAZ, 2006, p. 82) e o fato de encontrarem-se as organizações divididas por distintos "domínios de competência".

3) Van den Brink (2003) ao analisar como os fatores organizacionais afetam o compartilhamento de conhecimento, apontou os relacionados à estrutura e de que modo cada unidade de trabalho através de sua divisão de trabalho (processos de trabalho) pode conferir comportamentos distintos no compartilhamento.

4) Miranda e Moresi (2010) avaliaram mudanças organizacionais que influenciaram o compartilhamento de melhores práticas.

5) Grant (2011), ao tratar da especificidade de recursos colocados à disposição das organizações, colaborou para que inserissem perguntas voltadas à verificação do conhecimento que é particular a uma unidade e quanto isso pode alterar de alguma forma o compartilhamento.

As hipóteses que surgiram trataram da Lotação, buscando analisar o tipo de estrutura original do juiz (Vara JEF, Adjunta e Turma Recursal) e a competência dela (cível e criminal);

A pesquisa de campo do CJF possibilitou ao pesquisador vislumbrar uma possível relação do compartilhamento do conhecimento tácito com o tipo de unidade na qual o juiz encontrava-se lotado, ou seja, se a Vara era genuinamente de JEF, Adjunta ou se o juiz pertencia à Turma Recursal. As estruturas diferem, pelo menos, em número de servidores, cargos alocados (Analistas, Técnicos, Terceirizados), espaço interno e relação número de servidores / quantidade de processos judiciais.

Do trabalho de Tonet e Paz (2006), afloraram os questionamentos relacionados:

a) ao número de Varas estabelecidas nas proximidades física da Vara do juiz. Esta variável também ganhou peso a partir do trabalho de Corredoira e Rosenkopf (2010) ao identificarem uma relação entre compartilhamento e proximidade geográfica; entre emissor e receptor do conhecimento (variável "Geoproximidade") e duas empresas localizadas em uma mesma região metropolitana;

b) a competência da Vara. 
Assim, vislumbrou-se que impactam o compartilhamento:

1) O tipo de lotação (Vara JEF, JEF Adjunto, Turma Recursal-TR) (variável 'lotação' - pergunta 2.1).

2) A quantidade de Varas/TR em cada cidade (variável 'número de varas/TR' pergunta 2.2).

3) A competência da Vara cível/criminal (variável 'competência' - pergunta 2.1.1).

\subsubsection{Dimensão Geográfica}

Esta dimensão derivou:

a) Do estudo de Grant (2011) que apontou que o movimento de recursos humanos (de um ponto geográfico para outro) pode alterar a capacidade laboral da organização. O pesquisador supôs que padrões de desempenho de determinados juízes poderiam ser determinados pela sua posição geográfica dentro do mapa de Regiões dos JEF e caso isso acontecesse, poderiam ser 'exportados' de um juiz de uma Região/Estado/Município a outro. Deste modo, foi inserido um elemento hipotético de influência ao compartilhamento, a dimensão geográfica;

b) Da pesquisa realizada pelo Instituto de Pesquisa Econômica Aplicada (IPEA) em conjunto com o Conselho da Justiça Federal (CJF), ao avaliar os dez anos dos JEF, consideraram os aspectos geográficos relevantes em sua análise (IPEA, 2012);

c) Do trabalho de Miranda e Moresi (2010) que, da mesma forma, julgaram importante, ao avaliarem o compartilhamento de melhores práticas, a inclusão da variável, 'Estado em que atua'.

Nessa perspectiva, ampliou-se o conceito geográfico, adotando para essa representação, a Região, dentre as cinco que compõem a Justiça Federal, a Unidade da Federação (UF) e o município onde a Vara estava instalada. Assim, considerou-se que impactavam o compartilhamento:

1) A Região da Justiça Federal a que pertence a Vara/TR (variável 'Região' pergunta 2.3).

2) A Unidade da Federação a que pertence a Vara/TR (variável ' $U F$ ' - pergunta 2.4).

3) O município a que pertence a Vara/TR (variável 'Município' - pergunta 2.5). 


\subsubsection{Dimensão Social}

Um dos afluentes teóricos para a dimensão Social originou-se da pesquisa de Miranda e Moresi (2010) que apontou variáveis relacionadas ao compartilhamento: presença de juízes em encontros, infraestrutura tecnológica para compartilhamento, comunidades de prática, relação com desempenho organizacional e interesse dos magistrados em compartilhar e buscar sugestões com os pares para a melhoria dos serviços. Dessa forma, assumiu-se que impactavam o compartilhamento:

1) $\mathrm{O}$ fato de o juiz participar de forma presencial em eventos de natureza interativa (variável 'participação presencial' - pergunta 3.4).

2) O fato de o juiz participar em eventos de natureza virtual (variável 'participação virtual' - pergunta 3.5).

3) O fato de o juiz participar de alguma rede social que trate de temas profissionais (variável 'rede social' - pergunta 3.6).

Esta última variável hipotética (VH) ganhou força com o modelo de Sveiby (1997), onde a 'rede social' é apontada como uma espécie de competência relacionada ao conhecimento humano e com os estudos de Davenport e Prusak (1999) que avaliaram serem as redes os melhores sinais de um mercado de conhecimento e onde as pessoas perguntam sobre 'quem conhece o quê', 'quem conhece a teoria ...' ou 'onde posso achar ...'.

Durante o contato com uma juíza federal de JEF na cidade de Recife, foi percebido que, enquanto ocorria a entrevista, a magistrada compartilhava por meio do seu smartphone. Perguntada se aquilo ocorria de forma frequente, ela respondeu que sim e que abrangia questões de toda sorte: entendimento judicial e jurídico; dicas de manuseio dos sistemas informatizados, datas de encontros de juízes, boas práticas, bem como, novas doutrinas.

A essa experiência somou-se o alerta de Davenport e Prusak (1999) de que devemos considerar para o compartilhamento de conhecimento, além das conversas informais, o emprego de meios tecnológicos.

Van den Brink (2003), por sua vez, chamou a atenção para um aspecto semelhante ao conceituar a tecnologia como um artefato material que as pessoas se utilizam para a execução de suas tarefas.

Este conjunto de observações levou o pesquisador a supor que:

- O fato de o juiz empregar alguma tecnologia de comunicação particular (smartphone, i-phones, tablets, i-pads, outros) impacta o compartilhamento (variável 'tecnologia particular' - pergunta 3.7). 
Outro aspecto analisado pelo pesquisador a partir da revisão de literatura nasceu da contribuição de Tsai (2001) quando concluiu que unidades organizacionais com diferentes acessos ao conhecimento apresentam impactos distintos em seu desempenho. A variável hipotética (VH), assim, foi apresentada da seguinte forma:

- O fato de o juiz concordar que o compartilhamento é relevante para o desenvolvimento organizacional impacta o compartilhamento (variável 'desenvolvimento organizacional' - pergunta 4.1).

Em outro momento, por ocasião do pré-teste, o pesquisador, ao discutir as perguntas do questionário, percebeu a ênfase que o juiz defendia a ideia do compartilhamento do conhecimento tácito. Com base nesse diálogo, desenvolveu a seguinte hipótese derivada:

- O fato de o juiz concordar que o compartilhamento é imprescindível aos juízes para o melhor exercício de sua atividade judiciária impacta o compartilhamento (variável 'imprescindibilidade' - pergunta 4.2).

Os estudos de Van Caenegem (2005), onde se discutiu a importância da natureza privada/pública do conhecimento tácito para o encorajamento à sua difusão, sustentou uma nova proposição:

- O fato de o juiz julgar que o seu conhecimento tácito é privado ou público impacta o compartilhamento (variável ‘conhecimento público' - pergunta 4.3).

Com o estabelecimento dessas variáveis, o instrumento de coleta de dados e informações, o questionário, foi elaborado.

Além do Termo de Consentimento, o questionário dividiu-se em três partes, cada qual abrangendo um grupo de variáveis hipotéticas $(\mathrm{VH})$. A primeira parte abrange as dimensões Pessoal, Acadêmica e Funcional, a segunda contempla as dimensões Organizacional e Geográfica. A terceira, a dimensão Social.

As variáveis de natureza Pessoal (P) levam em consideração a pessoa do juiz. São: nome, gênero, idade, naturalidade. As variáveis de caráter Acadêmico (A) abrangem: grau de formação, docência e publicações. As questões que tratam da área Funcional (F) levam em conta, tempo de magistratura, instância da lotação (Vara/"1 $1^{\circ}$ grau" ou Turma Recursal/"22 grau"), e a hierarquia do juiz na Vara (Juiz Titular ou Substituto).

A segunda parte do questionário traz as dimensões organizacional e geográfica. A dimensão Organizacional (O), ocupa-se com as características da Vara no que diz respeito a especialização (juizados plenos ou adjuntos), competência (cível ou criminal) e quantidade de 
Varas existente na localidade onde trabalha o juiz. A dimensão Geográfica (G) trata de identificar a Região a que pertence a Vara e em qual cidade/UF está situada.

A última dimensão, Social $(\mathrm{S})$, abarca questões relacionadas às variáveis $(\mathrm{VH})$ que tratam da socialização, momento do compartilhamento do conhecimento tácito. Nesta dimensão também foram tratadas questões ${ }^{65}$ relacionadas à frequência de interação de juízes com juízes, com ASJ e com servidores (VInt), isto é, do juiz com a sua rede de compartilhamento (RC).

Por meio desse fluxo interativo, retirou-se a frequência de interação ${ }^{66}$, gerando valores satisfatórios para a formulação de uma variável que exprimiu o trânsito de conhecimento tácito, o indicador de propensão ao compartilhamento de conhecimento tácito (i $\mathrm{i}_{\mathrm{CCT}}$ ).

Ainda nesta dimensão, foram inclusas perguntas relacionadas à participação em eventos interativos ${ }^{67}$, ao vínculo com alguma rede social de caráter técnico, ao emprego de aparelhos de comunicação particulares (tablets, smartphones) ${ }^{68}$, à frequência de contato funcional $^{69}$, à relevância ao desenvolvimento organizacional; à imprescindibilidade para o exercício da magistratura e à rede de compartilhamento intra-regional, inter-regional e nacional (VH).

As seis dimensões que englobam as 23 hipotéticas $(\mathrm{VH})$ e as três variáveis interativas (VInt) estão expressas de forma resumida pela tabela abaixo. Os números entre parênteses referem-se às perguntas dispostas no questionário.

\footnotetext{
${ }^{65}$ Perguntas 3.1, 3.2 e 3.3 do questionário.

${ }^{66}$ A frequência foi conhecida quando o juiz, ao responder a pergunta, informou em uma escala de zero a dez, o valor que ele/ela consideravam pertinente para valorar tal interação.

67 Aqui, se refere a eventos presenciais, como, JEF itinerante, FONAJEF, encontros, jornadas, simpósios, congressos, workshops, bem como, eventos virtuais.

${ }^{68}$ Em entrevista com juízes da $5^{\text {a }}$ Região, lotados em Recife (PE), ocorrida em 25.11.2013, citou-se o uso da ferramenta WhatsApp como meio para troca de conhecimento tácito.

${ }^{69}$ Dos juízes pesquisados com desembargadores; com juízes em auxílio à presidência/corregedoria; com juízes coordenadores de JEF; com juízes do âmbito estadual, trabalhista.
} 


\section{Quadro 11 - Dimensões (D) e Variáveis Interativas (VInt) e hipotéticas (VH)}

\begin{tabular}{|c|c|c|}
\hline $\begin{array}{l}\text { D 1: Pessoal } \\
\text { VH: (1.2) gênero, (1.4) idade, } \\
\text { (1.5) naturalidade. }\end{array}$ & $\begin{array}{l}\text { D2: Acadêmica } \\
\text { VH: (1.6) grau de formação, } \\
\text { (1.7) docência, (1.8) publicação } \\
\text { (livros e artigos). }\end{array}$ & $\begin{array}{l}\text { D3: Funcional } \\
\text { VH: (1.9) anos de trabalho como juiz (mas } \\
\text { não em JEF), (1.10) titularidade } \\
\text { (titular/substituto), (1.11) anos de trabalho } \\
\text { como juiz (em JEF). }\end{array}$ \\
\hline $\begin{array}{l}\text { D 4: Organizacional } \\
\text { VH: (2.1) lotação (vara/vara } \\
\text { adjunta/turma recursal), } \\
\text { (2.1.1) Competência } \\
\text { (civil/criminal), (2.1.2) } \\
\text { número de varas no } \\
\text { município. }\end{array}$ & $\begin{array}{l}\text { D 5: Geográfica } \\
\text { VH: (2.3) região, (2.4) UF, } \\
\text { (2.5) município }\end{array}$ & $\begin{array}{l}\text { D 6: Social } \\
\text { VInt: (3.1) frequência de interação entre } \\
\text { juízes, (3.2) frequência de interação entre } \\
\text { juízes e ASJ, (3.3) frequência de interação } \\
\text { entre juízes e servidores, } \\
\text { VH: (3.4) frequência de participação } \\
\text { presencial em eventos de natureza interativa, } \\
\text { (3.5) frequência de participação em eventos } \\
\text { virtuais, (3.6) rede social, (3.7) tecnologia } \\
\text { particular de comunicação, (3.9) decisão para } \\
\text { compartilhamento, (4.1) relevância do } \\
\text { compartilhamento para desenvolvimento } \\
\text { organizacional, (4.2) concordância que o } \\
\text { compartilhamento é imprescindível para } \\
\text { exercício da atividade judiciária, (4.3) } \\
\text { natureza do conhecimento. }\end{array}$ \\
\hline
\end{tabular}

Fonte: Do autor.

3.4.3.7 A validação do questionário de coleta de dados e informações

O questionário, depois de elaborado, foi submetido a uma empresa de pesquisa e estatística $^{70}$ para validação. O propósito era verificar se as questões guardavam capacidade de reunir dados e informações dos juízes e que pudessem servir de base à busca por variáveis explicativas (VE) do compartilhamento de conhecimento tácito. Algumas questões foram reescritas e outras tiveram a escala de medição alterada.

\subsubsection{Pré-teste}

Com o fim de identificar e dirimir possíveis incompreensões, falhas, respostas inapropriadas ou inadequadas, bem como verificar se as respostas a serem dadas iriam atender aos objetivos e expectativas da pesquisa (PARRA FILHO, 1998), foi realizado um pré-teste do questionário com juízes de JEF.

O teste serviu de aprendizagem ao pesquisador, quanto ao real entendimento do que desejava pesquisar e daquilo que buscava recuperar de dados e informações (GRESSLER, 2003), assim como, levantar novas questões a serem conduzidas.

\footnotetext{
${ }^{70}$ Essa análise foi apoiada pela empresa de Estatística em Pesquisa Científica Odds \& Actions, que colaborou na etapa estatística da pesquisa. Disponível em: 〈http://oddsactions.com.br/>.
} 
Os pré-testes foram aplicados em duas fases. A primeira deu-se por e-mail com juízes localizados fora da cidade do pesquisador, Brasília-DF. A segunda, ocorreu pessoalmente com os residentes da capital, incorporando as sugestões e críticas efetuadas na primeira fase.

Durante as duas fases, algumas questões foram modificadas por gerar dúvidas na compreensão, outras foram acrescidas por sugestão dos juízes e uma foi retirada por não sustentar as hipóteses. Ao final do processo o questionário foi considerado pelos juízes como compreensível, adequado às suas atividades e de fácil preenchimento.

\subsubsection{Abordagem junto aos Tribunais e juízes}

$\mathrm{O}$ contato do pesquisador com os TRF deu-se pessoalmente com visitas às cinco capitais onde estão situadas as respectivas sedes (Brasília, Rio de Janeiro, São Paulo, Porto Alegre e Recife).

Com os TRF1, TRF2, TRF3 e TRF5, o contato foi realizado com as Coordenadorias Regionais dos JEF. Com o TRF4, ocorreu com a Presidência. Não houve reuniões do pesquisador com os desembargadores. $\mathrm{O}$ assunto foi tratado com seus assessores quando se explicou o objeto da pesquisa, os objetivos e o questionário de coleta de dados e informações.

As perguntas foram formatadas em um questionário-web na plataforma Surveymonkey e enviadas aos cinco TRF onde os JEF estão localizados, com o fim de serem reenviados aos juízes federais selecionados. Posteriormente, um email foi enviado aos Tribunais para formalizar a pesquisa, contendo o link da pesquisa ${ }^{71}$ e como anexos a carta da Orientadora e os elementos da pesquisa (Anexo D).

O TRF1, por meio de sua Coordenadoria de JEF, encaminhou email aos juízes selecionados (Anexo F) no qual estavam anexadas as comunicações do pesquisador. O TRF2, por meio de seu Presidente, expediu um ofício autorizando e prescrevendo algumas orientações (Anexo G). No TRF3, a ação foi intermediada por um servidor, assessor do Presidente, resultando no encaminhamento de um email da Coordenadoria dos JEF aos juízes (Anexo H). A autorização no TRF4 foi conduzida com o assessor do Presidente, com a expedição de um ofício (Anexo I). No TRF5, as ações foram conduzidas pela Coordenadoria dos JEF e um email foi enviado aos juízes (Anexo J). Em todos os TRF, a participação das Coordenadorias foi fundamental para a execução do estudo.

Ato seguinte, os Tribunais, já contatados pelo pesquisador e concordantes com a pesquisa, remeteram o web-questionário aos juízes selecionados na amostra. Este processo, no

${ }^{71}$ Disponível em: 〈https://pt.surveymonkey.com/s/ferretti_pesquisa〉. 
entanto, não se revelou eficaz, apenas 17 juízes atenderam ao convite. O pesquisador iniciou outro processo, o de chamadas telefônicas para cada juiz, somando um total de 50 respondentes em junho e 95 em dezembro de 2014.

Até o preenchimento dos questionários, a cada juiz foram direcionadas em média cinco ligações telefônicas, o que totalizou aproximadamente 500 ligações. Em razão da carga de trabalho, dos horários de funcionamento distintos a cada Região e da disponibilidade de tempo dos juízes, os contatos telefônicos ocorriam de forma esparsa durante todo o dia e às vezes à noite, de acordo com a agenda dos juízes.

O método caminha para a etapa 4 - Criação da unidade de medida com o fim de atender ao Objetivo Específico 3 - Identificar as variáveis que explicam o fenômeno do compartilhamento do conhecimento tácito dentre as variáveis possíveis mapeadas.

A partir do mapeamento realizado com as variáveis que teoricamente poderiam explicar o compartilhamento do conhecimento tácito no âmbito dos JEF (as variáveis hipotéticas - VH), foram identificadas as que comprovadamente (por meio de ferramentas estatísticas) pudessem explicar significativamente o fenômeno.

O pesquisador utilizou da criação de um indicador numérico que mensurasse o compartilhamento do conhecimento tácito, até então desconhecido na literatura, para realizar a tarefa.

\subsubsection{Etapa 4 - Criação da unidade de medida}

A mensuração do conhecimento tem sido vista como um negócio arriscado (NONAKA; TAKEUCHI, 1997). Algumas empresas veem esse empreendimento como de difícil execução (CHRISTENSEN, 2007). Medi-lo parece ser um desafio frente às opiniões de diversos estudiosos (ITAMI, 1987; INKPEN, 1996; ALVARENGA NETO, 2007; CHRISTENSEN, 2007; IPEA, 2015).

No campo do Judiciário, tem-se no relatório de pesquisa acerca da proposição de um modelo de GC para o Tribunal de Justiça de Pernambuco que: "Em geral, torna-se complicado definir indicadores porque se trata de mensurar algo que na maioria das vezes é tácito e, portanto, de difícil codificação e valoração" (DA SILVA, 2004, p. 68).

A pesquisa, contudo, levou em consideração os estudos de Sveiby (1997) e Silva (2004). O primeiro abordou bens invisíveis (intangíveis), a competência dos empregados ou o relacionamento com clientes e argumentou que esses bens são difíceis de medir, não porque são invisíveis, diferentemente de produtos, mas por falta um padrão de medição. O segundo 
colocou que a ação de mensuração do conhecimento está diretamente relacionada à capacidade de as organizações disseminá-lo.

Em se tratando do conhecimento tácito como um ativo invisível (intangível), entende o pesquisador que, ao se propor um processo de medição, retira ou ameniza-se o seu caráter de invisibilidade, possibilitando a gestão e o seu melhor emprego como ativo valioso que é.

Nessa senda, procurou-se estabelecer relações, papel próprio da ciência, entre as variáveis representativas do fenômeno estudado (VICINI, 2005). Posteriormente, de posse das variáveis explicativas (VE) pôde-se explicar o fenômeno.

A criação do indicador deu-se em quatro estágios: primeiro, a avaliação do grau de correlação entre as três variáveis interativas (VInt) relacionadas à rede de compartilhamento (RC) que aferiram o grau de interação entre o agente central e os coparticipantes.

A esta rede pertencem o agente central (juiz), os seus pares (outros juízes), os agentes externos (ASJ) e os membros da sua equipe (servidores). Cada variável está atrelada a uma pergunta do questionário $(3.1,3.2,3.3)$ e mede com valores numéricos $(0,10)$ o citado grau de interação. Foi estipulada uma variável para medir o grau de interação entre o agente central e seus pares; outra, que avaliou o grau de interação com os agentes externos; e uma terceira, do agente central com os membros de sua equipe.

O segundo estágio tratou da síntese das VInt, ou seja, das três VInt para uma variável, o indicador, variável chave da pesquisa. No terceiro, observou-se a parametrização do indicador dentro do intervalo $(0,1)$. No quarto foi verificado o grau de correlação entre as três VInt e o indicador.

3.4.4.1 Estágio 1 - a avaliação do grau de correlação entre as variáveis interativas (VInt)

Este estágio representa uma medida de segurança a fim de que não haja perda significante de informação durante o estágio seguinte, quando ocorrerá a redução das três variáveis independentes para somente uma, o indicador.

A correlação pode ser comprovada se observarmos a qualidade dessas métricas segundo a Matriz de Correlações de Pearson cujo coeficiente (r) varia no intervalo [-1,1]. Um valor próximo a 0,5 demonstra correlação linear positiva.

Em caso de "não correlação", os valores se posicionariam próximos de zero. Para uma correlação negativa, os valores teriam o sinal negativo. A correlação negativa aponta para o aumento de uma variável, a queda de valor de outras, isto é, um aumento da propensão ao compartilhamento entre o agente central (o juiz) e seus pares refletiria uma queda da 
propensão ao compartilhamento entre juízes e os agentes externos (ASJ) e entre o agente central e a sua equipe.

A pesquisa lança mão dessa técnica para avaliar qual correlação existe entre as variáveis VInt e se o comportamento dessas variáveis é consistente, similar e concordante.

Com a garantia de as VInt estarem linear e positivamente correlacionadas (Tabela 2), verificou serem essas boas métricas para se estimar o grau de propensão dos juízes em compartilhar, tornando razoável a proposição de um indicador que resumisse as informações nelas contidas em somente uma variável.

Tabela 2 - Grau de Correlação entre as VInt ${ }^{72}$

\begin{tabular}{c|c|c|c}
\hline Variáveis (VInt) & $\mathbf{3 . 1}$ & $\mathbf{3 . 2}$ & $\mathbf{3 . 3}$ \\
\hline $\mathbf{3 . 1}$ & 1,000 & 0,697 & 0,396 \\
$\mathbf{3 . 2}$ & & 1,000 & 0,449 \\
$\mathbf{3 . 3}$ & & & 1,000 \\
\hline
\end{tabular}

$\mathrm{r}$ - Coeficiente de correlação de Pearson [-1,1].

Fonte: Do autor.

Os valores alcançados podem ser comparados com a Quadro 12, com o fim de se verificar o grau de correlação.

Quadro 12 - Graus de correlação

\begin{tabular}{|c|c|}
\hline Coeficiente de correlação & Grau de correlação \\
\hline $\mathrm{r}=1$ & Perfeita positiva \\
\hline $0,8 \leq \mathrm{r}<1$ & Forte positiva \\
\hline $0,5 \leq \mathrm{r}<0,8$ & Moderada positiva \\
\hline $0,1 \leq \mathrm{r}<0,5$ & Fraca positiva \\
\hline $0<\mathrm{r}<0,1$ & Ínfima positiva \\
\hline 0 & Ínfima negativa \\
\hline$-0,1<\mathrm{r}<0$ & Fraca negativa \\
\hline$-0,5<\mathrm{r} \leq-0,1$ & Moderada negativa \\
\hline$-0,8<\mathrm{r} \leq-0,5$ & Forte negativa \\
\hline$-1<\mathrm{r} \leq-0,8$ & Perfeita negativa \\
\hline $\mathrm{r}=-1$ & \\
\hline
\end{tabular}

Fonte: SOUSA (2016).

Isso implica que um aumento de resposta na variável 3.1 gera aumento nas variáveis 3.2 e 3.3. Da mesma forma, esse comportamento ocorre entre as variáveis 3.2 e 3.3. No que diz respeito ao compartilhamento, pode-se predizer que dos juízes que mais trocam com outros juízes, espera-se também maior compartilhamento com os ASJ e com os membros da equipe de servidores.

\footnotetext{
${ }^{72}$ Perguntas 3.1, 3.2, 3.3 do questionário.
} 
3.4.4.2 Estágio 2 - Síntese das variáveis interativas (VInt)

Esse estágio foi marcado pelo processo de síntese das três VInt em uma variável, o indicador. Esta ação visa simplificar o método. Não se tratava mais de manusear três variáveis, mas de apenas uma, o indicador. O uso deste mecanismo permitiu a redução da complexidade da pesquisa, sem grande perda de informação.

Para esse fim, foi escolhida a ferramenta estatística, Análise de Componente Principal (ACP) que reduz a dimensão de um problema de ' $n$ ' variáveis para uma quantidade menor que 'n' (JOLLIFFE, 2002). Por esse meio, reduzem-se as sobreposições e escolhe a forma mais representativa das combinações lineares das VInt.

Esta técnica pertencente ao campo da Análise Multivariada que em termos estatísticos engloba "todas as técnicas ${ }^{73}$ e simultaneamente analisam múltiplas medidas dos indivíduos sob investigação. Qualquer análise simultânea, de mais do que duas variáveis, pode ser considerada, a princípio, como multivariada" (HAIR, 2009, p. 23).

Pela ACP, quando as variáveis independentes (VInt) apresentam correlação positiva, a variável resultante (dependente - o indicador), ao resumir grande parte da informação contida nas três variáveis, sumariza a variabilidade contida nessas variáveis, ou seja, a variável resultante (indicador) pode expressar sem prejuízo informacional o conteúdo das variáveis formadoras (independentes).

Os valores indicados pelos juízes nas perguntas que tratam do grau de interação na rede de compartilhamento foram de caráter numérico (de zero a 10). Isso também foi levado em conta para o emprego da ACP.

A primeira componente $\left(\mathrm{C}_{1}\right)^{74}$ apresentou $68 \%$ da proporção da variância dos dados e resumiu, assim, grande parte da informação contida nas três variáveis (VInt) e tornou-se o indicador.

3.4.4.3 Estágio 3 - Parametrização do indicador dentro do intervalo $(0,1)$

A parametrização do indicador dentro do intervalo $(0,1)$ visou aos seguintes propósitos:

a) estabelecer um intervalo mais confortável para futuras interpretações; e

\footnotetext{
${ }^{73}$ Outras técnicas são: Análise Discriminatória e Análise Fatorial.

${ }^{74}$ Por meio da ACP, identificam-se ainda mais duas componentes $\left(\mathrm{C}_{2}\right.$ e $\left.\mathrm{C}_{3}\right)$ que somam $100 \%$ das informações. Todavia, é a primeira, $\mathrm{C}_{1}$, que carrega a maior parte de significância, isto é, contém a maior quantidade de informação $\left(\mathrm{C}_{2}\right.$ e $\mathrm{C}_{3}$ possuem valor percentual menor que $\left.\mathrm{C}_{1}\right)$. Como se deseja apenas uma variável, o método orienta a aproveitar-se somente a primeira.
} 
b) garantir a sua tradução em indicador numérico de fácil e simples manuseio.

Para tanto, aplicou-se a seguinte transformação sobre os escores de $C_{1}\left(S_{1}\right)$ :

$$
i C C T=\frac{S_{1 k}+\operatorname{Max}\left(\left|S_{1}\right|\right)}{\operatorname{Max}\left(S_{1 k}+\operatorname{Max}\left(\left|S_{1}\right|\right)\right)}
$$

Vez que, o $\mathrm{i}_{\mathrm{CCT}}$ é o indicador de compartilhamento de conhecimento tácito do $k$-ésimo indivíduo da amostra. $S_{l k}$ é o escore do $k$-ésimo indivíduo da amostra da primeira componente resultante da ACP. $S_{l}$ é o vetor de escores de todos os indivíduos da amostra da primeira componente resultante da ACP, $\mathrm{C}_{1}$.

Até aqui, não se atribuiu nenhum valor numérico ao indicador. Tão somente, por meio da ACP, foi considerada a sua configuração que absorveu as informações do $\mathrm{C}_{1}$ e a sua parametrização dentro do intervalo $[0,1]$.

3.4.4.4 Estágio 4 - Verificação do grau de correlação entre as variáveis e o indicador

A avaliação do grau de correlação entre as variáveis e o indicador foi realizada com o emprego da técnica Matriz de Dispersão ou 'gráfico de nuvem de pontos'. Os resultados da disposição dos pontos na 'nuvem' identifica a tipologia da correlação, conforme os exemplos indicados na Figura 12. 
Figura 12 - Exemplos de gráficos de dispersão (nuvens de pontos)

\section{Y}

Recta de regressão

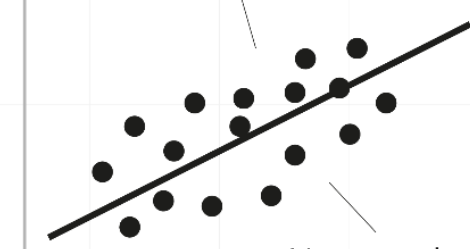

Nuvem de pontos

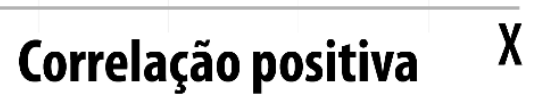

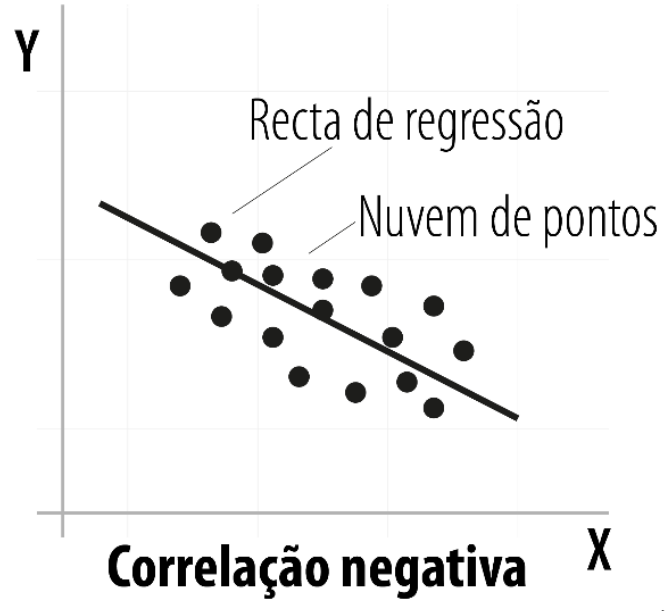

Correlação linear
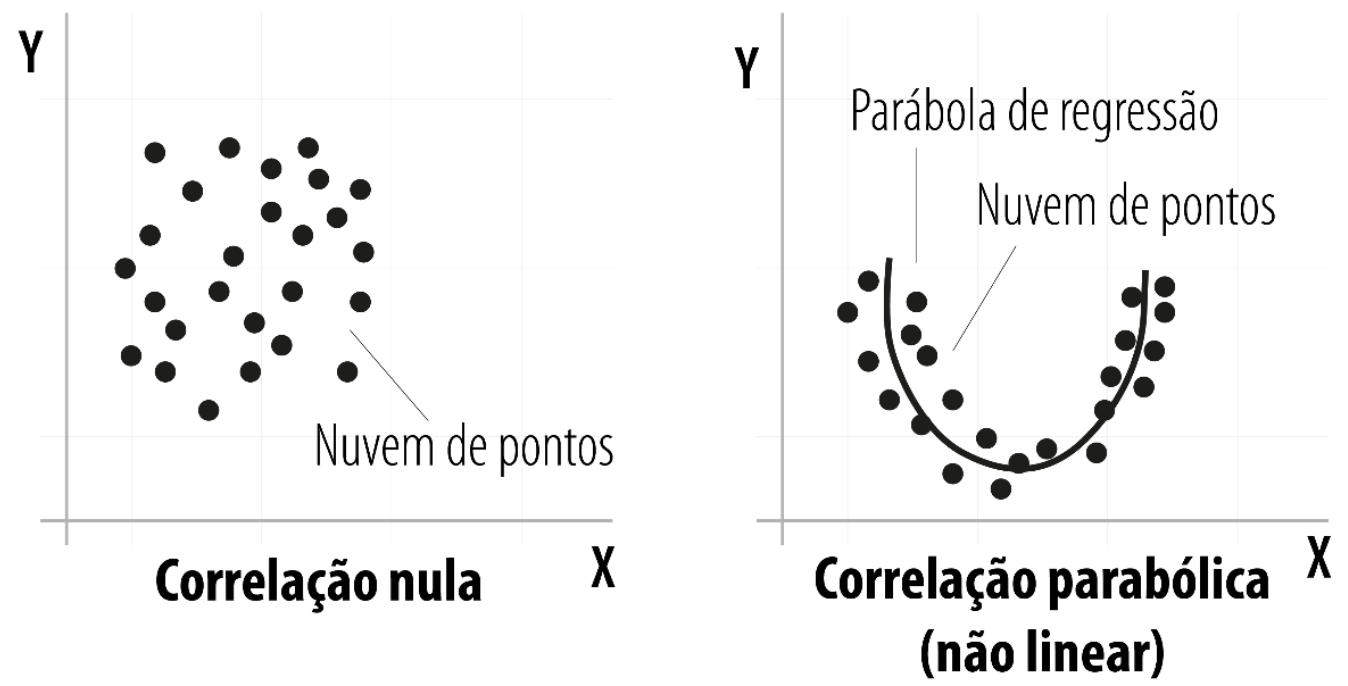

Fonte: Gráficos elaborados pelo autor com base em Werkema (2014).

Em se tratando da pesquisa, constatou-se que a 'nuvem de pontos' trouxe uma configuração em forma de reta ${ }^{75}$ cuja inclinação (coeficiente angular) indicou uma correlação linear positiva entre as variáveis interativas (VInt) e o indicador (Figura 13).

${ }^{75}$ Quanto mais os pontos se afastam da reta proposta, mais próximos estão de zero. 
Figura 13 - Matriz de dispersão das variáveis interativas (VInt) e o indicador

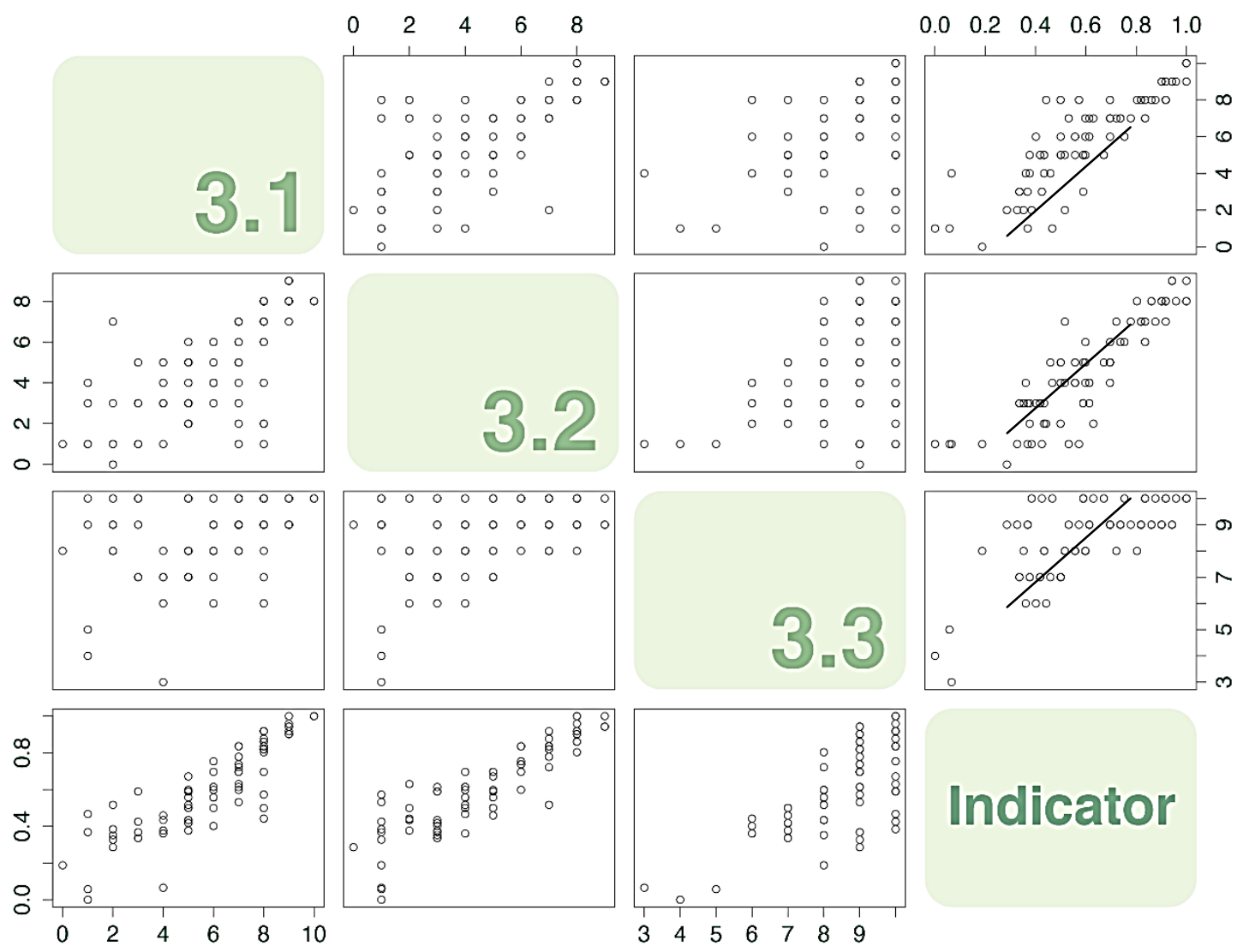

Fonte: Do autor.

Traduzidos em valores numéricos, esta correlação apresentou os seguintes resultados (Tabela 3).

Tabela 3 - Grau de correlação entre as variáveis e $0 \mathbf{i}_{\mathrm{CCT}}$.

\begin{tabular}{c|c}
\hline Correlação entre a variável e o indicador & 95 respondentes $^{76}$ \\
$(\mathrm{r})$ & \\
\hline $\mathrm{r} 3.1, \mathrm{i}_{\mathrm{CCT}}$ & 0,865 \\
$\mathrm{r} 3.2, \mathrm{i}_{\mathrm{CCT}}$ & 0,886 \\
$\mathrm{r} 3.3, \mathrm{i}_{\mathrm{CCT}}$ & 0,712 \\
\hline
\end{tabular}

Fonte: Do autor.

O indicador proposto, então, é uma boa proxy, isto é, uma boa aproximação da medição intencionada (KOGUT; ZANDER, 1993). No âmbito da pesquisa, o $\mathrm{i}_{\mathrm{CCT}}$ mostrou-se como um adequado mensurador da propensão ao compartilhamento do conhecimento tácito de juízes federais de JEF.

${ }^{76} 84$ juízes responderam e 11 ignoraram as questões $3.1,3.2$ e 3.3 . 


\subsubsection{Etapa 5 - Estimação dos impactos das variáveis hipotéticas (VH) sobre do indicador e a identificação das variáveis explicativas (VE)}

Até este momento, passos foram dados com o propósito de tornar concreta a existência de uma nova unidade de medida, o indicador. Nesta parte, fez-se necessário estimar os impactos das VH que podem ser determinantes na explicação do fenômeno do compartilhamento do conhecimento tácito.

Para estimar os impactos, foi utilizado o modelo de Regressão Beta (HUANG; OOSTERLEE, 2011) em razão de o indicador assumir valores no intervalo [0,1]. O modelo de regressão é uma técnica estatística empregada para analisar e modelar, com base em um banco de dados, a relação entre uma variável de interesse (o indicador) e um conjunto de variáveis explicativas, VInt e VH (BAYER, 2011).

Com isso, permitiu-se estimar:

a) a intensidade do impacto de cada VH sobre o indicador (23 VH);

b) o valor numérico do indicador para indivíduo dentro ou fora da amostra.

O modelo completo teórico tem a forma:

$$
i C C T=f(D 1, D 2, D 3, D 4, D 5, D 6)
$$

$\mathrm{i}_{\mathrm{CCT}}$ é o indicador de propensão ao compartilhamento do conhecimento tácito;

D1 é o vetor de variáveis associadas à primeira dimensão do estudo (pessoal);

D2 é o vetor de variáveis associadas à segunda dimensão do estudo (acadêmica);

D3 é o vetor de variáveis associadas à terceira dimensão do estudo (funcional);

D4 é o vetor de variáveis associadas à quarta dimensão do estudo (organizacional);

D5 é o vetor de variáveis associadas à quinta dimensão do estudo (geográfica);

D6 é o vetor de variáveis associadas à sexta dimensão do estudo (social);

Entretanto, nem todas as variáveis supostamente associadas ao indicador (VH) podem mostrar-se explicativas. Dessa forma, empregou-se o modelo de menor amplitude (Beta Reduzido), estimado a partir de um subconjunto das variáveis propostas na hipótese.

Esse subconjunto foi selecionado levando-se em consideração o nível de significância (p-valor) menor que $5 \%(<0,05)$ de cada variável no modelo. Valores nessa amplitude sinalizam que a variável estatística é significativa, traz impacto sobre o indicador e explica o compartilhamento do conhecimento tácito no âmbito dos JEF, segundo a concepção dos juízes. Os resultados estão expressos no item 4.2.1. 
O quadro 13 apresenta de forma resumida as etapas e os estágios do método empregado para a identificação das variáveis explicativas do fenômeno de compartilhamento de conhecimento tácito nos JEF e os objetivos específicos associados a cada etapa.

\section{Quadro 13 - Resumo das etapas, estágios, atividades do método e objetivos específicos relacionados}

\begin{tabular}{|c|c|c|c|}
\hline Item & $\begin{array}{l}\text { Etapas e } \\
\text { estágios }\end{array}$ & Atividades & Objetivos Específicos relacionados \\
\hline 3.4 .1 & Etapa 1 & Identificação do agente central & \multirow{2}{*}{$\begin{array}{l}\text { 1-Analisar o processo de } \\
\text { compartilhamento do conhecimento tácito } \\
\text { segundo a literatura; }\end{array}$} \\
\hline 3.4 .2 & Etapa 2 & $\begin{array}{llll}\text { Explicitação da } & \text { Rede } & \text { de } \\
\text { Compartilhamento (RC) } & & \end{array}$ & \\
\hline 3.4 .3 & Etapa 3 & $\begin{array}{l}\text { Mapeamento das possíveis variáveis } \\
\text { explicativas, estabelecimento das hipóteses } \\
\text { e elaboração do instrumento de coleta de } \\
\text { dados e informações (o questionário) }\end{array}$ & $\begin{array}{l}\text { 2-Mapear as possíveis variáveis } \\
\text { associadas ao compartilhamento do } \\
\text { conhecimento tácito entre os juízes do } \\
\text { JEF; }\end{array}$ \\
\hline \multirow[t]{5}{*}{3.4 .4} & Etapa $4 *$ & Criação da unidade de medida & \multirow{6}{*}{$\begin{array}{l}\text { 3-Identificar as variáveis que explicam o } \\
\text { fenômeno do compartilhamento do } \\
\text { conhecimento tácito dentre as variáveis } \\
\text { possíveis mapeadas. }\end{array}$} \\
\hline & Estágio 1 & $\begin{array}{l}\text { Avaliação do grau de correlação entre as } \\
\text { variáveis interativas (VInt) }\end{array}$ & \\
\hline & Estágio 2 & $\begin{array}{l}\text { Síntese das VInt (de três VInt, para uma } \\
\text { variável, o indicador) }\end{array}$ & \\
\hline & Estágio 3 & $\begin{array}{l}\text { Parametrização do indicador dentro do } \\
\text { intervalo }(0,1)\end{array}$ & \\
\hline & Estágio 4 & $\begin{array}{l}\text { Verificação do grau de correlação entre as } \\
\text { VInt e o indicador }\end{array}$ & \\
\hline 3.4 .5 & Etapa 5 & $\begin{array}{l}\text { Estimação dos impactos das variáveis } \\
\text { hipotéticas (VH) sobre do indicador e a } \\
\text { identificação das variáveis explicativas } \\
\text { (VE) }\end{array}$ & \\
\hline
\end{tabular}

Fonte: Do autor.

Nota: * Esta etapa foi dividida em quatro estágios. 


\section{RESULTADOS E DISCUSSÕES}

Ninguém pode vos revelar nada, a não ser o que jaz meio adormecido no âmago do vosso conhecimento (GIBRAN, 2002, p. 73).

Este capítulo apresenta os produtos obtidos durante o processo de busca da resposta à pergunta-problema,

Quais variáveis, na ótica dos juízes, explicam o compartilhamento do conhecimento tácito no âmbito dos JEF do Brasil? e comprova o alcance do objetivo proposto,

Identificar as variáveis que explicam o compartilhamento do conhecimento tácito no âmbito dos Juizados Especiais Federais (JEF), consoante a perspectiva dos juízes.

Inicialmente, os resultados da aplicação do questionário serão apresentados sob a forma de tabelas e gráficos. Os recursos visam proporcionar uma melhor disposição dos dados e das informações e uma maior clareza na interpretação desses resultados.

Posteriormente, verificaram-se os resultados relativos quando o método foi aplicado aos JEF e as variáveis explicativas (VE) analisadas.

\subsection{DADOS E INFORMAÇÕES COLETADOS DIRETAMENTE DAS RESPOSTAS DO QUESTIONÁRIO}

Com a aplicação do questionário, características da amostra foram recolhidas para descrevê-la (GIL, 2010).

Os questionamentos foram tabulados e tabelas e gráficos gerados a partir das respostas oferecidas pelos juízes, segundo a plataforma surveymonkey, onde estava hospedado o instrumento de coleta de dados e informações, o questionário (Apêndice A). Ao lado da nomenclatura dos quadros, estão identificados os números relativos às perguntas do questionário.

\subsubsection{Dimensão Pessoal}

No quesito gênero, (86R; 9I $)^{77}, 68,6 \%$ dos respondentes eram homens e 31,4\%, mulheres. Isso representou uma preponderância de juízes do gênero masculino sobre as de feminino.

\footnotetext{
${ }^{77}$ Para informar os indivíduos que responderam à pergunta será inserida a letra inicial "R". Com relação aos sujeitos que a ignoraram, será apresentada a letra "I".
} 
Tabela 4 - Gênero dos juízes (questão 1.2)

\begin{tabular}{c|c|c}
\hline Gênero & Percentual & Quantitativo \\
\hline Masculino & $68,6 \%$ & 59 \\
\hline Feminino & $31,4 \%$ & 27 \\
\hline Totais & $\mathbf{1 0 0 , 0 0 \%}$ & $\mathbf{8 6}$ \\
\hline
\end{tabular}

Gráfico 4 - Gênero dos juízes (questão 1.2)

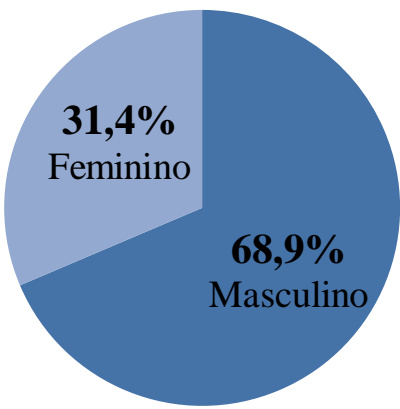

Fonte: Do autor.

Segundo os percentuais, nota-se que a proporção se manteve, pelo menos no que diz respeito aos juízes da $3^{\text {a }}$ Região $^{78}$, conforme estudo de Bonelli (2011) - Tabela 3.

Tabela 5 - Composição por gênero do Tribunal de Justiça de São Paulo e do Tribunal Regional Federal $3^{\text {a }}$ Região, segundo a instância e o gênero.

\begin{tabular}{|c|c|c|c|c|c|c|c|c|}
\hline & \multicolumn{4}{|c|}{ TJSP } & \multicolumn{4}{|c|}{ TRF da $3^{\text {a }}$ Região } \\
\hline & \multicolumn{2}{|c|}{$1^{\text {a }}$ Instância } & \multicolumn{2}{|c|}{$2^{\text {a }}$ Instância } & \multicolumn{2}{|c|}{ 1ª Instância } & \multicolumn{2}{|c|}{$2^{\mathrm{a}}$ Instância } \\
\hline & $\mathbf{N}$ & $\%$ & $\mathbf{N}$ & $\%$ & $\mathbf{N}$ & $\%$ & $\mathbf{N}$ & $\%$ \\
\hline $\mathrm{F}$ & 763 & 35,7 & 13 & 3,7 & 113 & 37,5 & 19 & 46,3 \\
\hline M & 1328 & 64,3 & 341 & 96,3 & 188 & 62,5 & 22 & 53,7 \\
\hline $\mathrm{T}$ & 2064 & & 354 & & 301 & & 41 & \\
\hline
\end{tabular}

Fonte: Bonelli (2011).

Quanto à idade (86R; 9I), entre 60 e 70 anos, encontraram-se dois respondentes $(2,32 \%)$; entre 50 e 60 anos, 12 (13,96\%). As faixas de 40 a 49 e de 30 a 39 anos apresentaram o mesmo número de respondentes, 36 (41,85\%), identificando o maior percentual de juízes nos grupos etários de 30 a 49 anos.

Tabela 6 - Ano de nascimento (questão 1.4)

\begin{tabular}{c|c|c|c}
\hline Faixa Etária & Nascidos entre & Percentual & Quantitativo \\
\hline Entre 60 e 70 anos & $1946-1955$ & $2,32 \%$ & 2 \\
Entre 50 e 59 anos & $1956-1965$ & $13,96 \%$ & 12 \\
Entre 40 e 49 anos & $1966-1975$ & $41,87 \%$ & 36 \\
Entre 30 e 39 anos & $1976-1986^{79}$ & $41,85 \%$ & 36 \\
\hline \multicolumn{2}{c|}{ Totais } & $\mathbf{1 0 0 \%}$ & $\mathbf{8 6}$ \\
\hline
\end{tabular}

Fonte: Do autor.

${ }^{78}$ A $3^{\text {a }}$ Região inclui os estados de SP e MS. Na pesquisa de Bonelli (2011), participaram juízes de JEF e não JEF.

${ }^{79}$ Por haver apenas um indivíduo nascido em 1986, ele foi incluído no último grupo. 


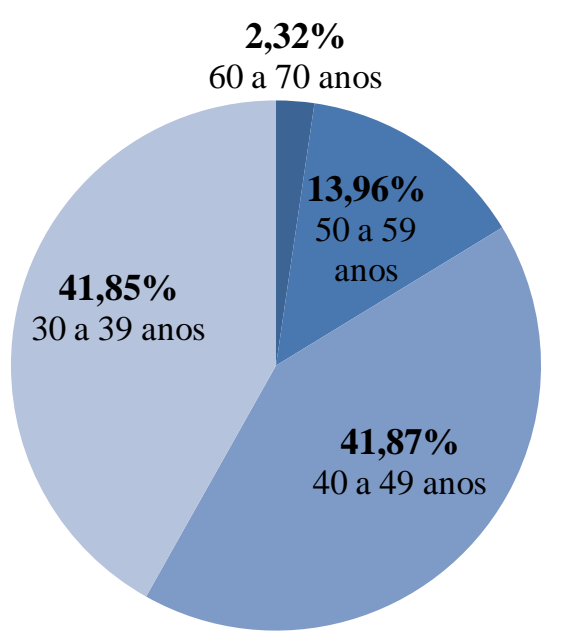

Fonte: Do autor.

Da naturalidade informada (86R; 9I), compilou-se que:

a) não houve respondentes das UF: Acre, Alagoas, Amapá, Maranhão, Mato Grosso do Sul, Roraima e Tocantins;

b) em ordem crescente, verificou-se um juiz das UF: Amazonas, Distrito Federal, Mato Grosso, Paraíba, Rondônia e Sergipe. Dois juízes dos estados: Espírito Santo, Goiás, Pará e Rio Grande do Norte. Três juízes do Piauí e Santa Catarina. Cinco juízes do Ceará. Seis, da Bahia e Pernambuco. Sete do Paraná. Nove do estado de Minas Gerais e 11 das unidades, Rio de Janeiro, Rio Grande do Sul e São Paulo.

Tabela 7 - Naturalidade - UF (questão 1.5)

\begin{tabular}{cccccccccccccccc}
\hline & Norte & \multicolumn{4}{c}{ Nordeste } & \multicolumn{4}{c}{ Centro-Oeste } & \multicolumn{4}{c}{ Sul } & \multicolumn{3}{c}{ Sudeste } \\
\hline UF & $\%$ & Qtd. & UF & $\%$ & Qtd. & UF & $\%$ & Qtd. & UF & $\%$ & Qtd. & UF & $\%$ & Qtd. \\
\hline AM & $1,16 \%$ & 1 & BA & $6,98 \%$ & 6 & DF & $1,16 \%$ & 1 & PR & $8,14 \%$ & 7 & ES & $2,33 \%$ & 2 \\
PA & $2,33 \%$ & 2 & CE & $5,81 \%$ & 5 & GO & $2,33 \%$ & 2 & RS & $12,79 \%$ & 11 & MG & $10,47 \%$ & 9 \\
RO & $1,16 \%$ & 1 & PB & $1,16 \%$ & 1 & MT & $1,16 \%$ & 1 & SC & $3,49 \%$ & 3 & RJ & $12,79 \%$ & 11 \\
& & & PE & $6,98 \%$ & 6 & & & & & & & SP & $12,79 \%$ & 11 \\
& & & PI & $3,49 \%$ & 3 & & & & & & & & & \\
& & & RN & $2,33 \%$ & 2 & & & & & & & & & \\
& & & SE & $1,16 \%$ & 1 & & & & & & & & & \\
\hline Total & $\mathbf{4 , 6 5 \%}$ & $\mathbf{4}$ & Total & $\mathbf{2 7 , 9 1 \%}$ & $\mathbf{2 4}$ & Total & $\mathbf{4 , 6 5 \%}$ & $\mathbf{4}$ & Total & $\mathbf{2 4 , 4 2 \%}$ & $\mathbf{2 1}$ & Total & $\mathbf{3 8 , 3 8 \%}$ & $\mathbf{3 3}$ \\
\hline
\end{tabular}

Fonte: Do autor.

Nota: Não houve respondentes das UFs: AC, AL, AP, MA, MS, RR e TO.

As regiões Norte e Centro-Oeste contribuíram com 4,65\% (quatro respondentes) cada; a região Sul, com 24,42\% (21 respondentes); a região Nordeste, com 27,91\% (24 
respondentes) e a região Sudeste, com 38,38\% (33 respondentes). Esta, com predomínio sobre as demais.

\section{Gráfico 6 - Distribuição dos juízes por Região}

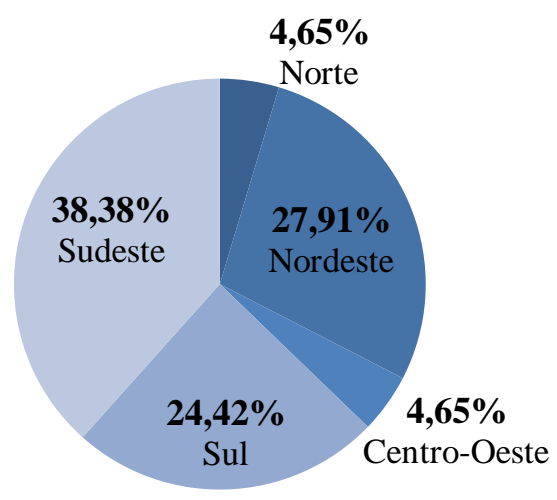

Fonte: Do autor.

\subsubsection{Dimensão Acadêmica}

Quanto ao grau de formação, (86R; 9I), 25 responderam ter concluído o curso de Graduação (29,08\%); 30 informaram possuir Pós-Graduação (34,88\%); 25 informaram possuir o grau de Mestrado (29,07\%); 5 possuem nível de Doutorado (5,81\%); e com PósDoutorado, um $(1,16 \%)$.

Apesar de ser obrigatória a graduação para a entrada no cargo, percebeu-se um avanço no aprimoramento com proporções relevantes para os graus de pós-graduação $(34,88 \%)$ e mestrado $(29,07 \%)$.

Tabela 8 - Grau de formação dos Gráfico 7 - Grau de formação dos juízes (questão juízes (questão 1.6)

\section{6)}

\begin{tabular}{r|c|c}
\hline \multicolumn{1}{c|}{ Grau } & Percentual & Quantitativo \\
\hline Graduação & $29,08 \%$ & 25 \\
Pós-graduação & $34,88 \%$ & 30 \\
Mestrado & $29,07 \%$ & 25 \\
Doutorado & $5,81 \%$ & 5 \\
Pós-doutorado & $1,16 \%$ & 1 \\
\hline Totais & $\mathbf{1 0 0 , 0 0 \%}$ & $\mathbf{8 6}$ \\
\hline
\end{tabular}

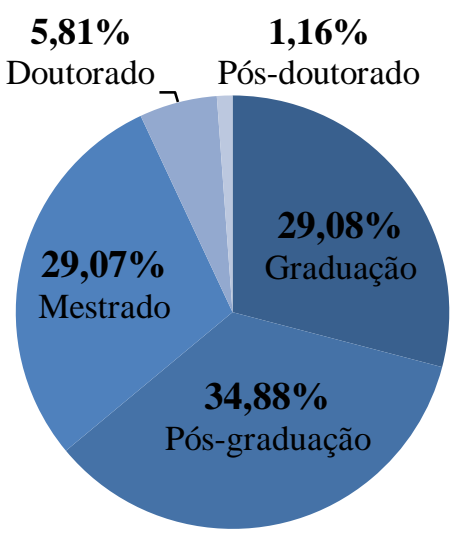

Fonte: Do autor.

Tendo por base o trabalho de Velloso (2004, p. 590) sobre o destino profissional de mestres e de doutores no Brasil (Tabela 7), constatou-se que o percentual de juízes nos JEF 
com a titulação de mestre $(29,07 \%)$ ultrapassa a média nacional na área correlata "Profissionais ${ }^{80}$, Administração/Serviço Público ${ }^{81 " ~(24,5 \%) . ~}$

Tabela 9 - Principais tipos de trabalho em que mestres e doutores estão ocupados, quanto ao grupo de grandes áreas do conhecimento $(\%)$.

\begin{tabular}{l|c|c|c|c|c|c}
\hline Grupos de grandes Áreas/Tipos de trabalho & \multicolumn{3}{|c|}{ Mestres } & \multicolumn{3}{c}{ Doutores } \\
\hline Básicas & Menor** & Média* & Maior** & Menor** & Média* & Maior** \\
\hline Universidade & 24,5 & 40,3 & 58,8 & 53,5 & 71,8 & 86,7 \\
Administração/serviços públicos & 4,9 & 18,3 & 29,1 & 2,9 & 9,4 & 27,8 \\
Empresa pública/privada & 3,6 & 17,4 & 26,2 & 2,7 & 3,9 & 5,8 \\
Instituição de pesquisa & 5,4 & 11,8 & 17,5 & 4,8 & 11,8 & 24,4 \\
Escritório ou consultório & & 2,4 & & & 0,5 & \\
Outros & 5,7 & 9,8 & 18,3 & & 2,5 & \\
\hline Tecnológicas & & & & & & \\
Universidade & 26,1 & 30,5 & 36,1 & 68,9 & 71,7 & 79,5 \\
Administração/serviços públicos & 10,8 & 14,5 & 17,0 & 2,5 & 6,0 & 8,4 \\
Empresa pública/privada & 34,0 & 39,2 & 46,8 & 9,9 & 12,2 & 15,4 \\
Instituição de pesquisa & & 4,4 & & & 7,7 & \\
Escritório ou consultório & & 3,5 & & & 1,7 & \\
Outros & 4,4 & 7,8 & 9,7 & & 0,6 & \\
\hline Profissionais & & & & & & \\
Universidade & 19,7 & 32,6 & 43,6 & 35,8 & 61,5 & 73,1 \\
Administração/serviços públicos & 2,3 & 24,5 & 52,6 & 6,5 & 17,0 & 28,5 \\
Empresa pública/privada & 0,04 & 16,3 & 36,7 & 4,2 & 5,2 & 13,9 \\
Instituição de pesquisa & & 2,1 & & & 2,1 & \\
Escritório ou consultório & 4,4 & 22,0 & 64,4 & 1,9 & 13,5 & 29,3 \\
Outros & & 2,5 & & & 0,7 & \\
\hline
\end{tabular}

Fonte: Velloso (2004, p. 590)

Nota:

* Porcentagem dos ocupados em um tipo de trabalho, segundo o grupo de grandes áreas do conhecimento.

** Porcentagem de ocupados em dado tipo de trabalho numa determinada área do conhecimento do grupo.

Obs.: não se indicam a menor e a maior porcentagem quando a diferença entre elas é menor que 5 pontos percentuais.

No que diz respeito aos doutores, fica o percentual obtido $(5,81 \%)$ abaixo do estipulado por Velloso (2004) como média nacional (17\%), dentro dos mesmos parâmetros "Profissionais, Administração/Serviço Público".

Quanto à atuação como docente, (86R; 9I), 46 responderam que atuaram ou atuam como docente $(53,49 \%)$ e 40 que não atuaram ou atuam $(46,51 \%)$.

\footnotetext{
${ }^{80}$ Área "Profissionais inclui: Administração, Clínica Médica, Direito, Economia, Odontologia e Psicologia.

${ }^{81}$ A categoria "administração e serviços públicos" abrange funcionários do Poder Executivo Federal, Estadual e Municipal (administração direta e indireta), assim como do Judiciário, Legislativo e Ministério Público.
} 
Tabela 10 - Atuação dos juízes como docentes (questão 1.7)

\begin{tabular}{c|c|c}
\hline Atuação & Percentual & Quantitativo \\
\hline Sim & $53,49 \%$ & 46 \\
Não & $46,51 \%$ & 40 \\
\hline
\end{tabular}

Fonte: Do autor.
Gráfico 8 - Atuação dos juízes como docentes (questão 1.7)

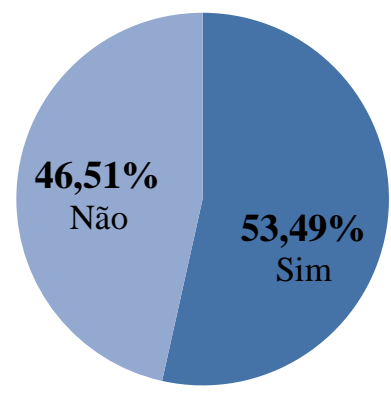

Com base nos percentuais, não houve superioridade de qualquer um dos segmentos sobre o outro, permanecendo um equilíbrio entre juízes docentes e não docentes.

Com relação à publicação de livros ou artigos, (86R; 9I), 54 dos juízes afirmaram já ter publicado livro ou artigo $(62,79 \%)$ e 32 que não publicaram. Verificou-se que os juízes de JEF apresentaram uma significativa disposição em publicar.

Tabela 11 - Publicação de livros, capítulos, Gráfico 9 - Publicação de livros, capítulos, artigos (questão 1.8) artigos (questão 1.8)

\begin{tabular}{c|c|c}
\hline Publicação & Percentual & Quantitativo \\
\hline Sim & $62,79 \%$ & 54 \\
Não & $37,21 \%$ & 32 \\
\hline Totais & $100,00 \%$ & 86 \\
\hline
\end{tabular}

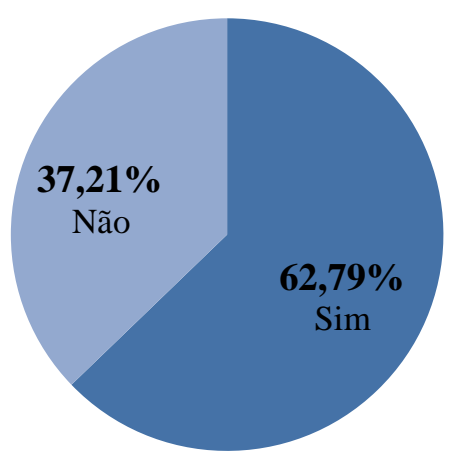

Fonte: Do autor.

\subsubsection{Dimensão Funcional}

Com respeito ao tempo de JF, (86R; 9I), ou seja, a quantidade de tempo que o juiz possuía na Justiça Federal desde a sua posse até o momento da pesquisa, havia 17 juízes com menos de cinco anos (19,77\%); 21, entre cinco e nove anos (24,42\%); 34 entre 10 e 15 anos $(39,53 \%)$ e 14 , com mais de 15 anos $(16,28 \%)$. 
Tabela 12 - Tempo de JF (questão 1.9)

\begin{tabular}{c|c|c}
\hline Tempo de JF & Percentual & Quantitativo \\
\hline Menos de 5 anos & $19,77 \%$ & 17 \\
Entre 5 e 9 anos & $24,42 \%$ & 21 \\
Entre 10 e 15 anos & $\mathbf{3 9 , 5 3 \%}$ & 34 \\
Mais de 15 anos & $16,28 \%$ & 14 \\
\hline Totais & $\mathbf{1 0 0 , 0 0 \%}$ & $\mathbf{8 6}$ \\
\hline
\end{tabular}

Fonte: Do autor.

Quanto à titularidade, (86R; 9I), se o juiz exerce a função de titular ou substituto, 61 juízes são titulares $(70,93 \%)$ e 25 , substitutos $(29,07 \%)$.

Tabela 13 - Titularidade (questão 1.10)

\begin{tabular}{c|c|c}
\hline Titularidade & Percentual & Quantitativo \\
\hline Titular & $\mathbf{7 0 , 9 3 \%}$ & 61 \\
Substituto & $\mathbf{2 9 , 0 7 \%}$ & 25 \\
\hline Totais & $\mathbf{1 0 0 , 0 0 \%}$ & $\mathbf{8 6}$ \\
\hline
\end{tabular}

\section{Gráfico 10 - Tempo de JF (questão 1.9)}

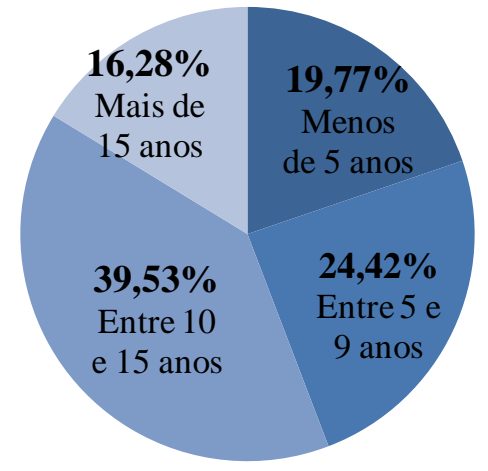

Fonte: Do autor.

Gráfico 11 - Titularidade (questão 1.10)

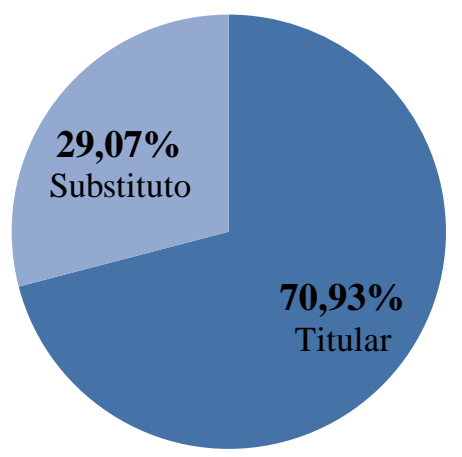

Com referência ao tempo de JEF, (86R; 9I), tempo este que o juiz encontrava-se lotado nos JEF, desde a sua remoção aos Juizados até o momento da pesquisa, destes, 16 juízes com menos de um ano $(18,61 \%) ; 15$, entre um e dois anos $(17,44 \%) ; 21$, entre três e cinco anos $(24,42 \%)$ e 34 , com mais de cinco anos $(39,53 \%)$.

Tabela 14 - Tempo de JEF (questão 1.11)

\begin{tabular}{c|c|c}
\hline Tempo de JEF & Percentual & Quantitativo \\
\hline Menos de 1 ano & $18,61 \%$ & 16 \\
De 1 a 2 anos & $17,44 \%$ & 15 \\
De 3 a 5 anos & $24,42 \%$ & 21 \\
Mais de 5 anos & $39,53 \%$ & 34 \\
\hline Totais & $\mathbf{1 0 0 , 0 0 \%}$ & $\mathbf{8 6}$ \\
\hline
\end{tabular}

Gráfico 12 - Tempo de JEF (questão 1.11)

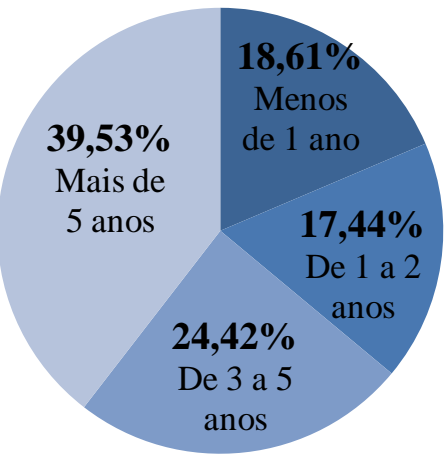

Fonte: Do autor. 


\subsubsection{Dimensão Organizacional}

No tocante à lotação, (85R; 10I), os juízes foram distribuídos, 41 em Vara JEF (48,24\%); 28 em Vara JEF Adjunto (32,94\%) e 16 em Turmas Recursais (18,82\%).

Tabela 15 - Lotação (questão 2.1)

\begin{tabular}{c|c|c}
\hline Lotação & Percentual & Quantitativo \\
\hline Vara JEF & $48,24 \%$ & 41 \\
Vara JEF Adjunto & $32,94 \%$ & 28 \\
Turma Recursal & $18,82 \%$ & 16 \\
\hline Totais & $\mathbf{1 0 0 , 0 0 \%}$ & $\mathbf{8 5}$ \\
\hline
\end{tabular}

\section{Gráfico 13 - Lotação (questão 2.1)}

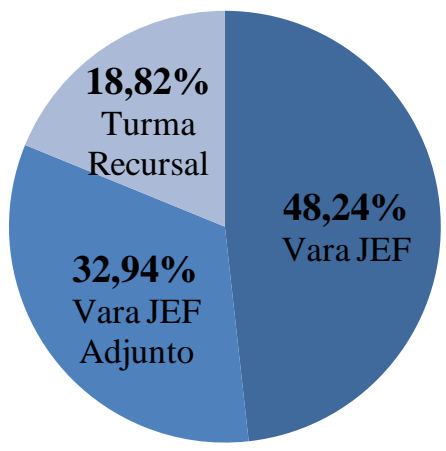

Fonte: Do autor.

Quanto à competência, (68R; 27I), os resultados mostraram que 60 Varas eram Cíveis $(88,24 \%)$ e oito, criminais $(11,76 \%)^{82}$.

Tabela 16 - Competência (questão 2.1.1)

\begin{tabular}{c|c|c}
\hline Competência & Percentual & Quantitativo \\
\hline Cível & $88,24 \%$ & 60 \\
Criminal & $11,76 \%$ & 8 \\
\hline Totais & $\mathbf{1 0 0 , 0 0 \%}$ & $\mathbf{6 8}$ \\
\hline
\end{tabular}

Fonte: Do autor.
Gráfico 14 - Competência (questão 2.1.1)

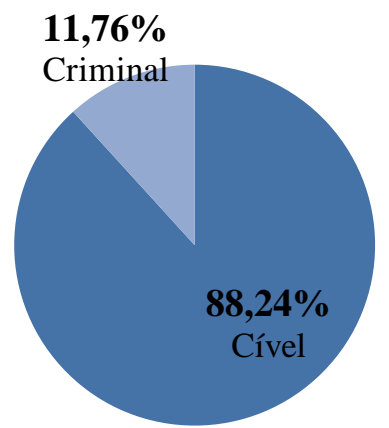

\subsubsection{Dimensão Geográfica}

Concernente à Região a que pertence a Vara/Turma Recursal, (84R; 11I), os juízes estavam assim distribuídos, 24 na $1^{\text {a }}$ Região (28,57\%); 12 na $2^{\text {a }}$ Região (14,29\%); 13 na $3^{\text {a }}$ Região (15,48\%); 20 na $4^{\mathrm{a}}$ Região $(23,81 \%)$ e 15 na $5^{\mathrm{a}}$ Região $(17,85 \%)$.

${ }^{82}$ O número alto de não respondentes (27) ocorre em razão de que, nas Turmas Recursais (TR), não há separação com base na competência, ou seja, não há TR Cível e TR Criminal. Assim, os juízes pertencentes às TR não responderam esse quesito. Todavia, essa taxa de não respondentes não influenciou a identificação das variáveis explicativas, como se viu no item 3.2 - População e amostra da pesquisa. 
Tabela 17 - Região (questão 2.3)

\begin{tabular}{c|c|c}
\hline Região & Percentual & Quantitativo \\
\hline Primeira Região & $28,57 \%$ & 24 \\
Segunda Região & $14,29 \%$ & 12 \\
Terceira Região & $15,48 \%$ & 13 \\
Quarta Região & $23,81 \%$ & 20 \\
Quinta Região & $17,85 \%$ & 15 \\
\hline Totais & $\mathbf{1 0 0 , 0 0 \%}$ & $\mathbf{8 4}$ \\
\hline
\end{tabular}

Fonte: Do autor.
Gráfico 15 - Região (questão 2.3)

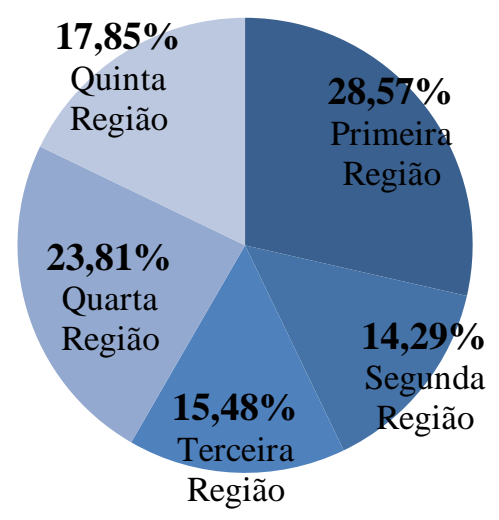

\subsubsection{Dimensão Social}

Para avaliar as frequências de interação dos juízes com os seus pares, com os ASJ e com os servidores de suas equipes, foram previstas três perguntas no questionário, 3.1, 3.2 e 3.3, expostas abaixo, seguidas de suas respectivas tabelas e gráficos.

Ao intervalo escalar foram atribuídas faixas de relevância, no sentido de facilitar a interpretação. Dessa forma, extraindo-se os valores zero, que representa ausência de interação e 10, que indica uma interação muito alta, às notas restantes adotou-se a seguinte classificação: intervalo $(1,3)$, interação fraca; $(4,6)$, interação mediana; $(7,9)$, interação alta.

Figura 14 - Faixas de relevância de interação quanto ao compartilhamento de conhecimento tácito

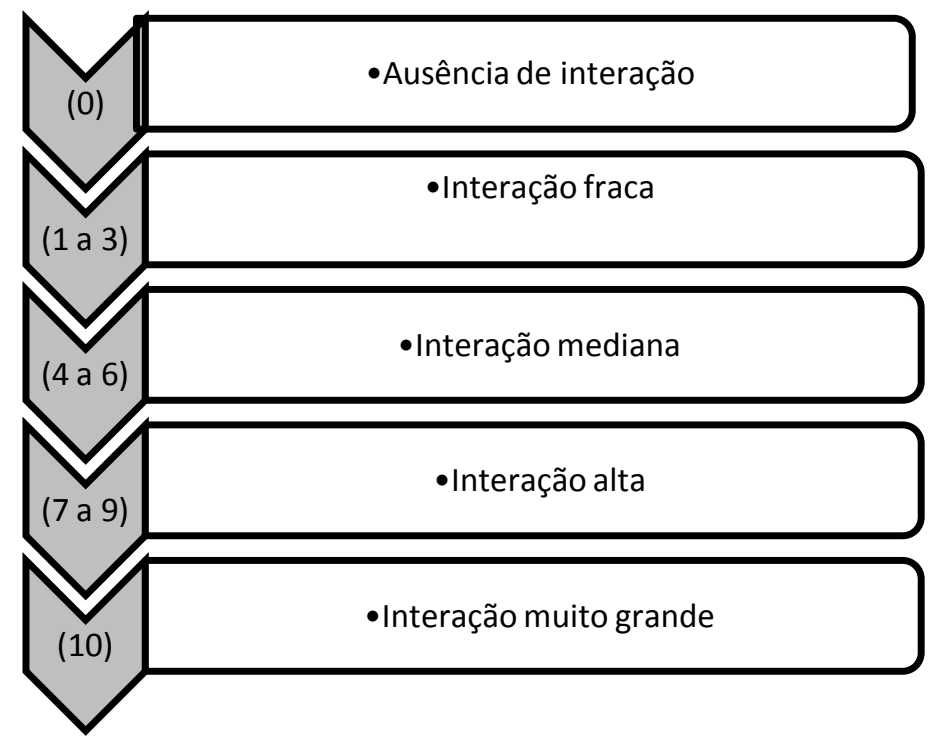

Fonte: Do autor 
3.1 Como Vossa Excelência considera o grau de intensidade de sua interação com outros juízes, no que diz respeito ao compartilhamento de ideias, experiências, expertise, habilidades, know-how, entendimentos jurídicos, modelos mentais e outros conteúdos mentais (conhecimento tácito)?

Tabela 18 - Frequência de interação dos juízes com seus pares*

\begin{tabular}{c|c|c}
\hline $\begin{array}{c}\text { Frequência de } \\
\text { interação }\end{array}$ & Percentual & Quantitativo \\
\hline 0 (Ausente) & $1,2 \%$ & 1 \\
1 & $4,8 \%$ & 4 \\
2 & $6,0 \%$ & 5 \\
3 & $6,0 \%$ & 5 \\
4 & $6,0 \%$ & 5 \\
5 & $15,5 \%$ & 13 \\
6 & $10,7 \%$ & 9 \\
7 & $16,7 \%$ & 14 \\
8 & $20,2 \%$ & 17 \\
9 & $10,7 \%$ & 9 \\
10 (Muito & $2,4 \%$ & 2 \\
grande) & & \\
\hline
\end{tabular}

Fonte: Do autor.

Nota: *No de Respondentes: 84; No Não Respondentes: 11.

Há uma expressiva concentração dos que responderam dentro da faixa, 'interação alta' $(47,6 \%)$. Para o intervalo de interação mediana, um percentual de $32,2 \%$ e de 'fraca interação, 16,8\%. Observa-se que há uma disposição dos juízes em compartilhar com seus pares.

3.2 Em relação a sua interação com os ASJ (advogados, procuradores, promotores, defensores), em que grau se dá a compartilhamento do conhecimento tácito? 
Tabela 19 - Frequência de interação Gráfico 17 - Frequência de interação dos juízes com dos juízes com Agentes do Sistema de Agentes do Sistema de Justiça (ASJ)

Justiça (ASJ)*

\begin{tabular}{c|c|c}
\hline $\begin{array}{c}\text { Frequência de } \\
\text { interação }\end{array}$ & Percentual & Quantitativo \\
\hline 0 (Ausente) & $1,2 \%$ & 1 \\
1 & $11,9 \%$ & 10 \\
2 & $7,1 \%$ & 6 \\
3 & $14,3 \%$ & 12 \\
4 & $11,9 \%$ & 10 \\
5 & $13,1 \%$ & 11 \\
6 & $8,3 \%$ & 7 \\
7 & $13,1 \%$ & 11 \\
8 & $15,5 \%$ & 13 \\
9 & $3,6 \%$ & 3 \\
10 (Muito & $0,0 \%$ & 0 \\
\hline grande) & &
\end{tabular}

10 (Muito grande) $\quad 0,0 \%$

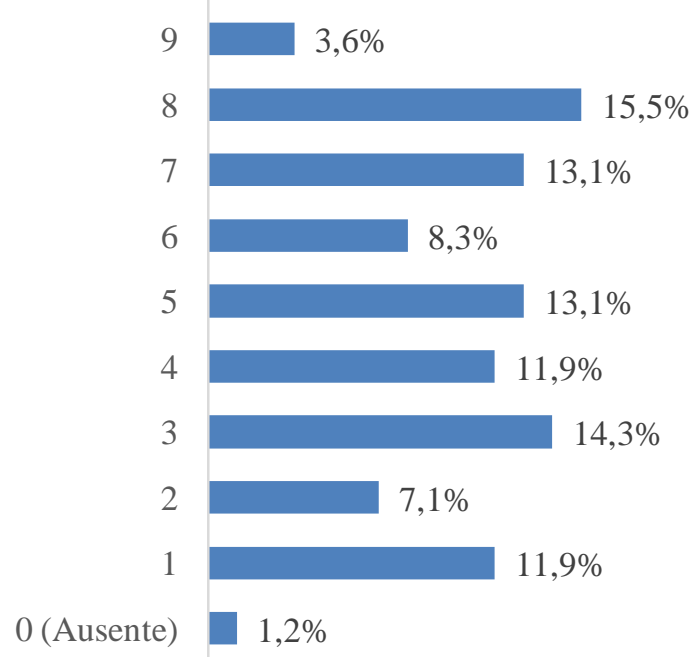

Fonte: Do autor.

Nota: *No de Respondentes: 84; No Não Respondentes: 11.

As respostas referentes à como os juízes pretendem interagir com os ASJ encontraramse muito divididas. Verifica-se que, diferentemente da interação com os seus pares, quando se percebeu um percentual de 2,4\% para a 'interação muito grande', com os ASJ, no entanto, não houve qualquer juiz que indicasse esse nível de interação visando o compartilhamento.

Para o nível de 'interação alta' e 'interação mediana', apresentaram-se, respectiva e aproximadamente, os mesmos valores, $32,2 \%$ e 33,3\%, totalizando, $65,5 \%$ dos juízes. A medida representa uma boa aceitação dos juízes em estabelecer interação com os ASJ.

Nota-se, contudo, que mais de um terço dos juízes, 33,3\%, mostraram-se com nível de 'interação fraca' e 1,2\% dos juízes, o mesmo percentual obtido com relação aos pares, demostraram 'ausência de interação".

3.3 Em relação a sua interação com os servidores de sua Vara, em que nível se dá o compartilhamento do conhecimento tácito? 
Tabela 20 - Frequência de interação Gráfico 18 - Frequência de interação dos juízes com dos juízes com servidores membros de servidores membros de sua equipe sua equipe*

\begin{tabular}{c|c|c}
\hline $\begin{array}{c}\text { Frequência de } \\
\text { interação }\end{array}$ & Percentual & Quantitativo \\
\hline 0 (Ausente) & $0,0 \%$ & 0 \\
1 & $0,0 \%$ & 0 \\
2 & $0,0 \%$ & 0 \\
3 & $1,2 \%$ & 1 \\
4 & $1,2 \%$ & 1 \\
5 & $1,2 \%$ & 1 \\
6 & $3,6 \%$ & 3 \\
7 & $14,3 \%$ & 12 \\
8 & $17,9 \%$ & 15 \\
9 & $34,5 \%$ & 29 \\
10 (Muito & $26,2 \%$ & 22 \\
grande) & & \\
\hline
\end{tabular}

\section{0 (Muito grande)}

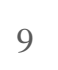

8

7

6

6

5 | $1,2 \%$

$4-1,2 \%$

$3 \mathbf{1 , 2} \%$

$20,0 \%$

$10,0 \%$

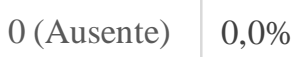

Fonte: Do autor.

Nota: * $\mathrm{N}^{\circ}$ de Respondentes: 84; $\mathrm{N}^{\circ}$ Não Respondentes: 11.

A primeira constatação é a de que $26,2 \%$ dos juízes informaram que com os servidores membros de suas equipes de trabalho a interação é 'muito grande'. Em seguida, constatou-se um expressivo percentual de 'interação alta', 66,7\%. Caso sejam somados os percentuais de 'interação muito grande' e 'interação alta', o total perfaz 92,9\% dos juízes, quase a totalidade da amostra.

Outra verificação é a de que o nível 'ausência de interação', pontuado em ambos os grupos acima (pares e ASJ) com valor 1,2\%, com os servidores, apresentou-se nulo $(0,0 \%)$ e a faixa 'interação fraca', somente $1,2 \%$.

O modelo de Tonet e Paz (2006) permitiu ao pesquisador compreender melhor o alto índice de compartilhamento entre juízes e servidores. O fenômeno pode ocorrer quando se observa o processo de indução ao compartilhamento dentro da própria unidade de trabalho para a busca de solução de problemas ou para atender demandas por conhecimento.

Para as questões 3.4 e 3.5, as respostas seguem a escala abaixo. 
Figura 15 - Faixas de relevância quanto à intensidade de participação em eventos

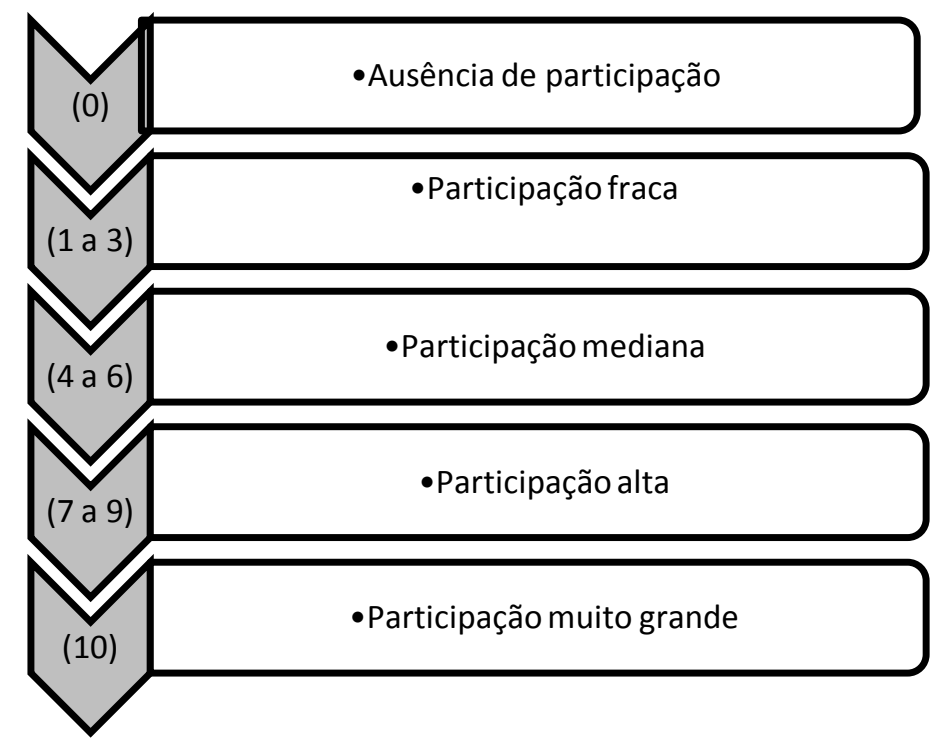

Fonte: Do autor.

3.4 Em qual grau de intensidade se dá a sua participação presencial em eventos de natureza interativa?

Tabela 21 - Frequência de Gráfico 19 - Frequência de participação do juiz em participação do juiz em eventos de eventos de natureza presencial natureza presencial*

\begin{tabular}{c|c|c}
\hline $\begin{array}{c}\text { Frequência de } \\
\text { interação }\end{array}$ & Percentual & Quantitativo \\
\hline 0 (Ausente) & $3,6 \%$ & 3 \\
1 & $6,0 \%$ & 5 \\
2 & $4,8 \%$ & 4 \\
3 & $3,6 \%$ & 3 \\
4 & $7,1 \%$ & 6 \\
5 & $17,9 \%$ & 15 \\
6 & $11,9 \%$ & 10 \\
7 & $13,1 \%$ & 11 \\
8 & $17,9 \%$ & 15 \\
9 & $13,1 \%$ & 11 \\
10 (Muito & $1,2 \%$ & 1 \\
grande) & & \\
\hline
\end{tabular}

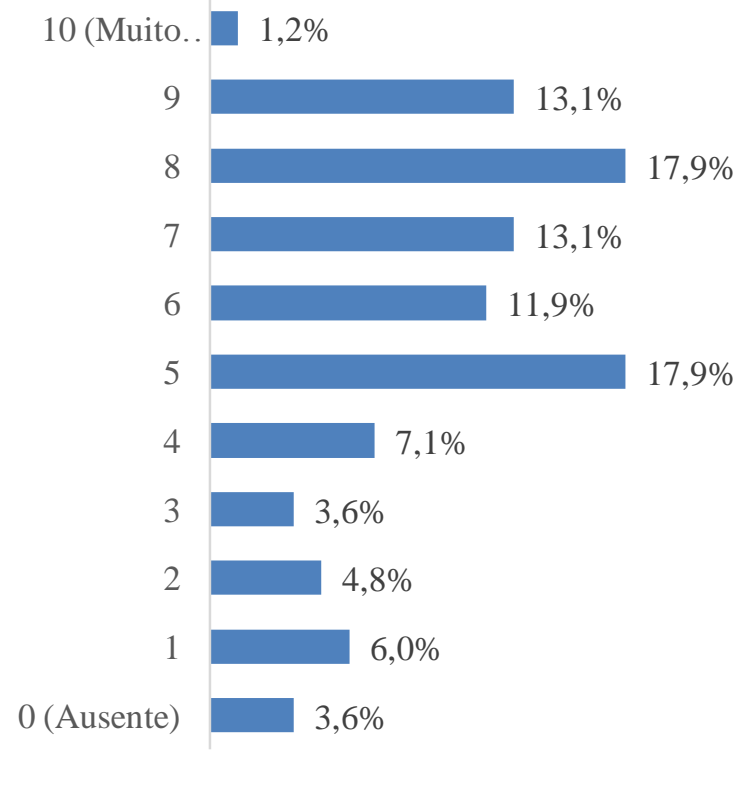

Fonte: Do autor.

Nota: * $\mathrm{N}^{\mathrm{o}}$ de Respondentes: 84; $\mathrm{N}^{\mathrm{o}}$ Não Respondentes: 11.

Tratando-se do grau de intensidade em que ocorre a participação presencial em eventos de natureza interativa, $(84 \mathrm{R} ; 11 \mathrm{I})$, os juízes confirmaram a presença em eventos de 
natureza interativa, com 1,2\% classificando esse grau de participação como 'muito grande' e 44,1\%, como 'participação alta'. Outros 36,9\% posicionaram-se com uma 'participação mediana' e $14,4 \%$, como 'participação fraca'.

\subsection{Em qual grau de intensidade se dá a sua participação em eventos virtuais?}

Tabela 22 - Frequência de Gráfico 20 - Frequência de participação do juiz em participação do juiz em eventos de eventos de natureza virtual natureza virtual*

\begin{tabular}{c|c|c}
\hline $\begin{array}{c}\text { Frequência } \\
\text { de interação }\end{array}$ & Percentual & Quantitativo \\
\hline 0 (Ausente) & $13,1 \%$ & 11 \\
1 & $10,7 \%$ & 9 \\
2 & $6,0 \%$ & 5 \\
3 & $11,9 \%$ & 10 \\
4 & $4,8 \%$ & 4 \\
5 & $19,0 \%$ & 16 \\
6 & $17,9 \%$ & 15 \\
7 & $9,5 \%$ & 8 \\
8 & $3,6 \%$ & 3 \\
9 & $2,4 \%$ & 2 \\
10 (Muito & $1,2 \%$ & 1 \\
\hline grande) & &
\end{tabular}

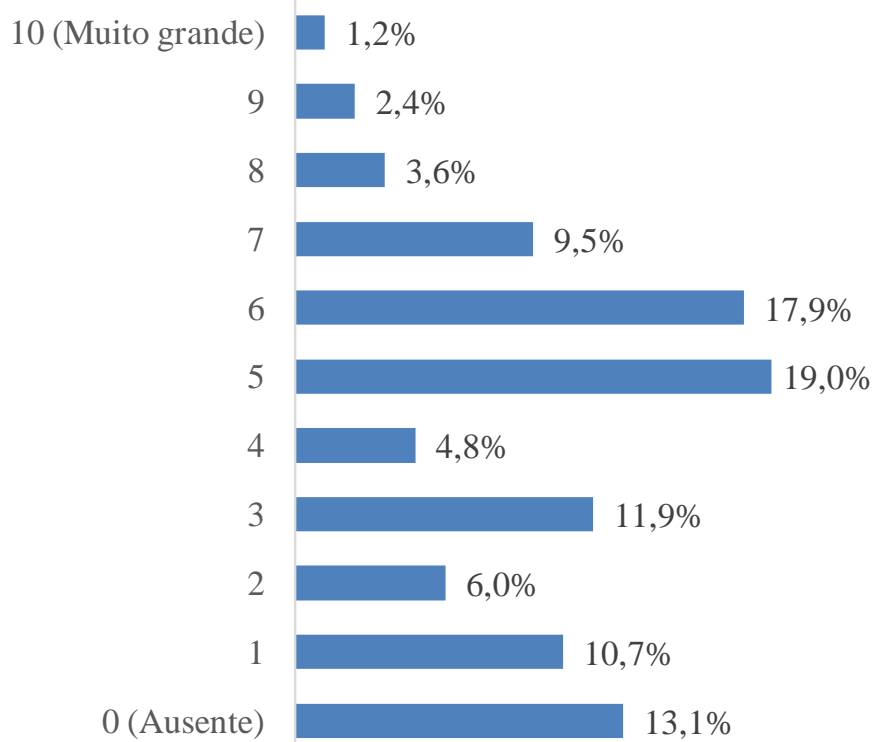

Fonte: Do autor.

Nota: * $\mathrm{N}^{\mathrm{o}}$ de Respondentes: 84; $\mathrm{N}^{\mathrm{o}}$ Não Respondentes: 11.

A predisposição dos juízes em participar de eventos de natureza interativa não ficou comprovada para os eventos de natureza virtual. Embora o percentual de 'interação muito grande' tenha sido o mesmo (1,2\%), houve uma queda na avaliação dos juízes quanto à 'participação alta'. Dos 44,1\% registrados para participação presencial, apenas 15,5\% reagiram favoráveis a esse nível, quando a presença tornou-se virtual. Os percentuais para 'participação mediana' e 'fraca', no entanto, evoluíram, respectivamente para 41,7\% e 28,6\%, indicando uma transferência de intenção para patamares inferiores quando a participação torna-se virtual.

Os questionamentos seguintes tratam respectivamente de participação em rede social (pergunta 3.6) e emprego de tecnologia de comunicação para compartilhamento (pergunta 3.7). As respostas foram compiladas no formato "sim/não". 
3.6 Vossa Excelência participa de alguma rede social que trate de temas profissionais?

Tabela 23 - Participação dos juízes em Gráfico 21 - Participação dos juízes em rede social rede social*

\begin{tabular}{c|c|c}
\hline $\begin{array}{c}\text { Frequência de } \\
\text { interação }\end{array}$ & Percentual & Quantitativo \\
\hline Sim & $38,1 \%$ & 32 \\
Não & $61,9 \%$ & 52 \\
\hline
\end{tabular}

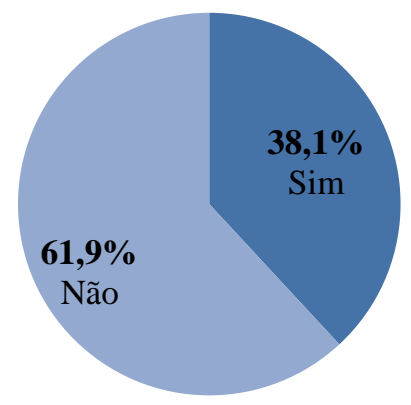

Fonte: Do autor.

Nota: *No de Respondentes: 84; $N^{o}$ Não Respondentes: 11.

Quando buscou conhecer qual proporção de juízes participavam de redes sociais cuja temática era de assuntos profissionais, obteve-se que 61,9\% não pertenciam a redes dessa natureza e $38,1 \%$, sim.

3.7 Vossa Excelência emprega alguma tecnologia de comunicação PARTICULAR (smartphone, i-phones, tablets, i-pads, outros) para compartilhamento de conhecimento tácito (ideias, experiências, expertise, habilidades, entendimentos jurídicos, modelos e outros conteúdos mentais)?

Tabela 24 - Emprego de tecnologia Gráfico 22 - Emprego de tecnologia de comunicação de comunicação particular para o particular para o compartilhamento de conhecimento compartilhamento de conhecimento tácito tácito *

\begin{tabular}{c|c|c}
\hline $\begin{array}{c}\text { Frequência } \\
\text { de interação }\end{array}$ & Percentual & Quantitativo \\
\hline Sim & $60,7 \%$ & 51 \\
Não & $39,3 \%$ & 33 \\
\hline
\end{tabular}

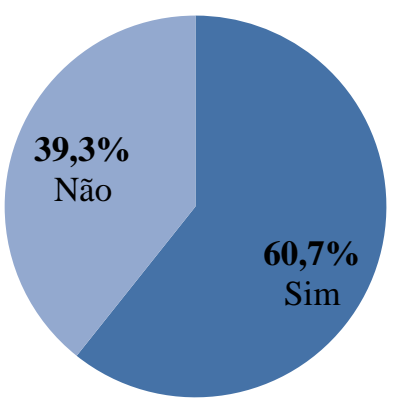

Fonte: Do autor.

Nota: *No de Respondentes: 84; Nº Não Respondentes: 11.

Os juízes que fizeram uso de alguma tecnologia de comunicação particular como smartphone, i-phones, tablets, i-pads, notebooks, para compartilhamento de conhecimento tácito somaram $60,7 \%$. Os que não se utilizam de meios tecnológicos privados totalizaram $39,3 \%$. 
A questão (3.8) trata da verificação da escolha dos pares, dos ASJ e dos servidores como grupos mais relevantes para a composição da Rede de Compartilhamento (RC). Aos juízes foi solicitado que assinalassem até três opções.

\subsection{Quando Vossa Excelência compartilha conhecimento tácito, este acontece mais frequentemente com?}

Tabela 25 - Indivíduos com os quais os juízes mais compartilha

\begin{tabular}{r|c}
\hline \multicolumn{1}{c|}{ Indivíduos } & Percentual \\
\hline Juiz (a) Desembargador(a) Federal & $6,0 \%$ \\
Juiz(a) Federal Titular de Vara & $59,0 \%$ \\
Juiz(a) Federal Titular de Turma Recursal & $32,5 \%$ \\
Juiz(a) Federal Substituto(a) & $56,6 \%$ \\
Juiz(a) em Auxílio à Presidência & $0,0 \%$ \\
Juiz(a) em Auxílio à Corregedoria & $0,0 \%$ \\
Juiz(a) em Auxílio à Coordenação dos Juizados (COJEF) & $0,0 \%$ \\
Juiz Estadual (inclui desembargadores estaduais) & $0,0 \%$ \\
Juiz Trabalhista (inclui desembargador trabalhista) & $0,0 \%$ \\
Operadores de Direito & $28,9 \%$ \\
Servidor(a) & $74,7 \%$ \\
\hline
\end{tabular}

Fonte: Do autor.

Nota: ${ }^{*} \mathrm{~N}^{\mathrm{o}}$ de Respondentes: 83; $\mathrm{N}^{\mathrm{o}}$ Não Respondentes: 12.

Os resultados apontaram que os juízes compartilham mais com os seguintes grupos: outros juízes (seus pares), os ASJ (Operadores de Direito) e servidores. Esses quantitativos reforçam a seleção desses mesmos grupos para a composição da RC.

A pergunta a seguir (3.9) averigua qual o fator de maior peso influencia a decisão dos juízes em compartilhar o conhecimento tácito. A eles foram oferecidas quatro opções: proximidade física; nível de conhecimento no assunto; nível de afinidade de ideias e outros.

\subsection{Qual é o fator de maior peso na decisão pelo compartilhamento do conhecimento} tácito com os indivíduos assinalados no item anterior? 
Tabela 26 - Frequência de participação do juiz em eventos de natureza virtual*

\begin{tabular}{l|c|c}
\hline $\begin{array}{c}\text { Frequência } \\
\text { de interação }\end{array}$ & Percentual & Quantitativo \\
\hline $\begin{array}{l}\text { Proximidade } \\
\text { física }\end{array}$ & $32,1 \%$ & 27 \\
$\begin{array}{l}\text { Nível de } \\
\text { conhecimento } \\
\text { no assunto }\end{array}$ & $15,5 \%$ & 13 \\
$\begin{array}{l}\text { Nível de } \\
\text { afinidade de } \\
\text { ideias, } \\
\text { pensamentos } \\
\text { e valores } \\
\text { Outro. Qual? }\end{array}$ & $16,7 \%$ & 30 \\
\hline
\end{tabular}

Gráfico 23 - Frequência de participação do juiz em

eventos de natureza virtual

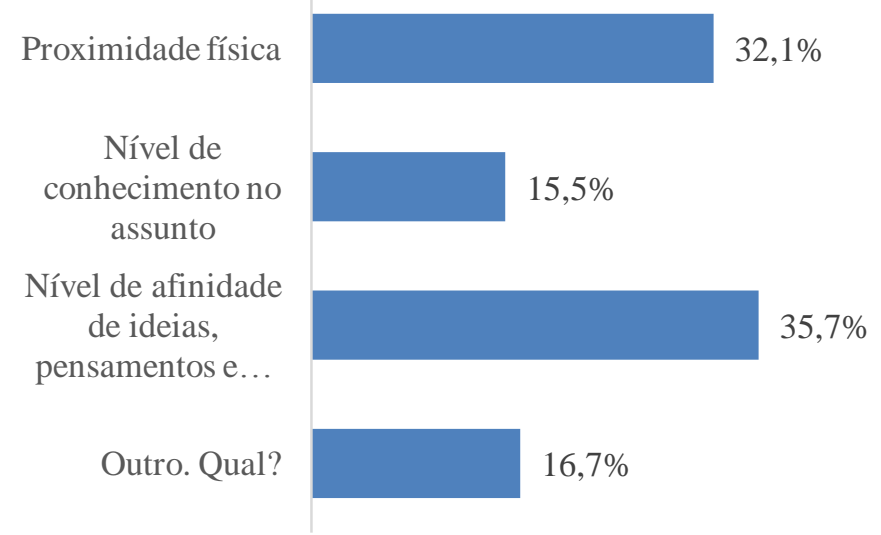

Fonte: Do autor.

Nota: * $\mathrm{N}^{\mathrm{o}}$ de Respondentes: 84; $\mathrm{N}^{\mathrm{o}}$ Não Respondentes: 11.

Entre os fatores de maior peso a compartilhar os juízes indicaram o 'nível de afinidade de ideias, pensamentos e valores' que reuniu 35,7\% dos respondentes e 'proximidade física', com $32,1 \%$. O fator 'nível de conhecimento no assunto' foi sugerido por 15,5\% e no campo 'outro' foram apontados 15 fatores por 14 juízes:

- "Proximidade" virtual (por redes e comunicador institucional);

- Abertura para troca de ideias;

- Necessidade de fornecer orientação aos servidores [quanto] à confiança no trabalho em relação aos Juízes;

- Identidade de competência jurisdicional;

- Condição de professor;

- Atuação funcional;

- Comunicabilidade;

- Manifestação de interesse;

- Proximidade profissional e experiência/conhecimento;

- Realizar o trabalho objetivando uma prestação jurisdicional rápida, eficaz e coordenada;

- Necessidade do trabalho cotidiano;

- Natureza do trabalho em equipe (que exige compartilhamento);

- Interação no trabalho;

- Alguns de meus servidores estão estudando para concurso e estão com alto grau de conhecimento; e

- Comunhão de objetivos.

As questões 4.1 e 4.2 pretendiam trazer a visão dos juízes quanto a dois quesitos relacionados ao compartilhamento de conhecimento tácito: 'desenvolvimento organizacional' 
e 'imprescindibilidade para o exercício da atividade judicante', conforme a experiência e vivência de cada um.

Para essas perguntas, serão utilizadas as seguintes faixas de relevância:

Figura 16 - Faixas de relevância quanto ao nível de concordância

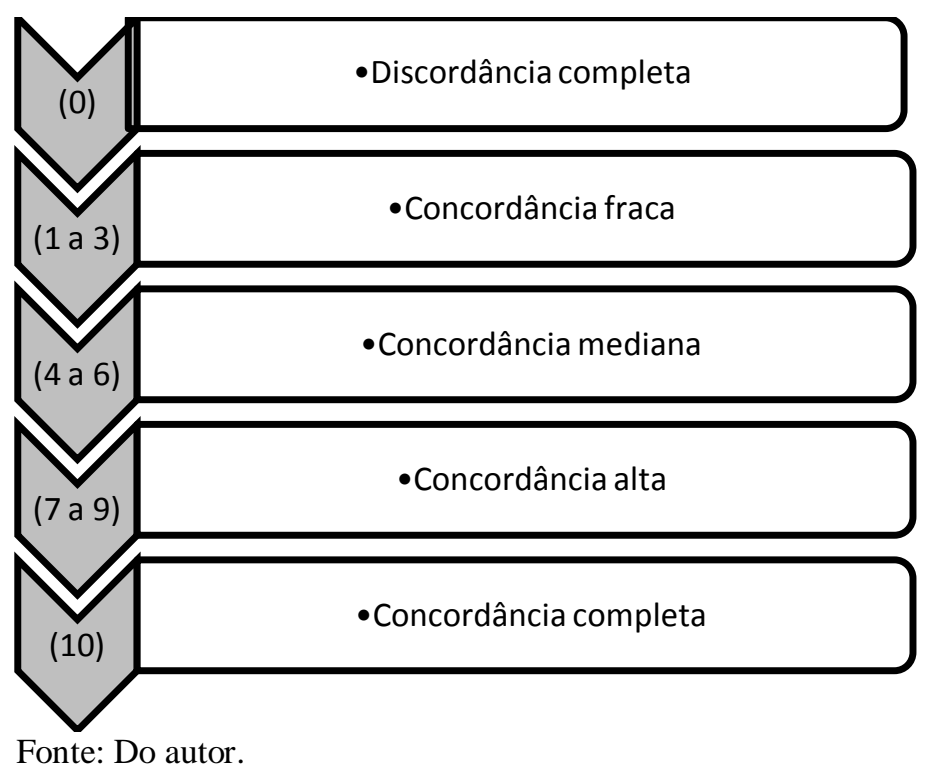

\subsection{Vossa Excelência concorda que o compartilhamento do conhecimento tácito é} relevante para o desenvolvimento organizacional?

Tabela 27 - Nível de concordância de Gráfico 24 - Nível de concordância de que o que o compartilhamento do compartilhamento do conhecimento tácito é conhecimento tácito é relevante para o relevante para o desenvolvimento organizacional desenvolvimento organizacional *

\begin{tabular}{c|c|c}
\hline $\begin{array}{c}\text { Frequência } \\
\text { de interação }\end{array}$ & Percentual & Quantitativo \\
\hline $\begin{array}{c}\text { (Discordo } \\
\text { plenamente) }\end{array}$ & $0,0 \%$ & 0 \\
1 & $0,0 \%$ & 0 \\
2 & $0,0 \%$ & 0 \\
3 & $1,2 \%$ & 1 \\
4 & $2,4 \%$ & 2 \\
5 & $6,0 \%$ & 5 \\
6 & $2,4 \%$ & 2 \\
7 & $11,9 \%$ & 10 \\
8 & $16,7 \%$ & 14 \\
9 & $16,7 \%$ & 14 \\
10 (Concordo & $42,9 \%$ & 36 \\
plenamente) & & \\
\hline
\end{tabular}

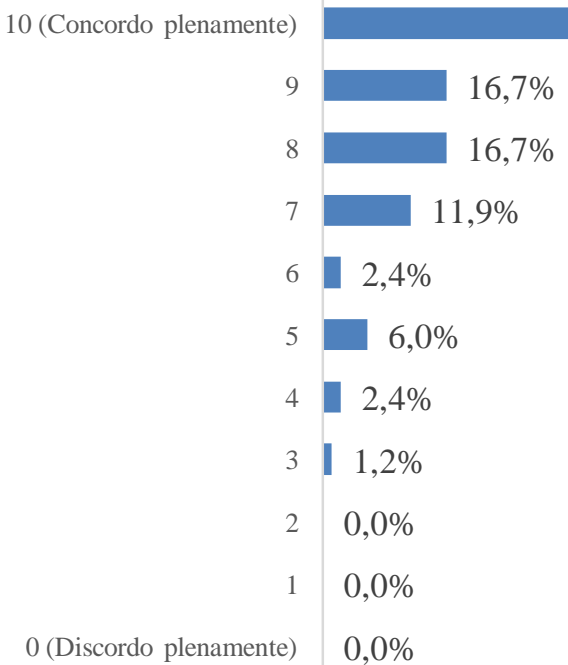

Fonte: Do autor.

Nota: * $\mathrm{N}^{\mathrm{o}}$ de Respondentes: 84; $\mathrm{N}^{\mathrm{o}}$ Não Respondentes: 11. 
Uma parcela expressiva dos juízes (42,9\%) apresentou opinião de 'total concordância' quanto ao fato de o compartilhamento de conhecimento tácito ser relevante para o desenvolvimento organizacional. A faixa de 'concordância alta' da mesma forma condensou $45,3 \%$ dos juízes. Se considerados de forma conjunta (88\%), para os juízes questionados o compartilhamento do conhecimento tácito encontra-se altamente relacionado com o tema 'desenvolvimento organizacional'. Os percentuais somados para 'concordância mediana' e 'fraca' totalizam $12 \%$.

4.2 Vossa Excelência concorda que o compartilhamento do conhecimento tácito é imprescindível aos juízes para o melhor exercício de sua atividade judiciária?

Tabela 28 - Nível de concordância de Gráfico 25 - Nível de concordância de que o que o compartilhamento do compartilhamento do conhecimento tácito é conhecimento tácito é relevante para o relevante para o desenvolvimento organizacional desenvolvimento organizacional *

\begin{tabular}{c|c|c}
\hline $\begin{array}{c}\text { Frequência } \\
\text { de interação }\end{array}$ & Percentual & Quantitativo \\
\hline $\begin{array}{c}\text { (Discordo } \\
\text { plenamente) }\end{array}$ & $0,0 \%$ & 0 \\
1 & $0,0 \%$ & 0 \\
2 & $0,0 \%$ & 0 \\
3 & $1,2 \%$ & 1 \\
4 & $2,4 \%$ & 2 \\
5 & $6,0 \%$ & 5 \\
6 & $2,4 \%$ & 2 \\
7 & $11,9 \%$ & 10 \\
8 & $16,7 \%$ & 14 \\
9 & $16,7 \%$ & 14 \\
10 (Concordo & $42,9 \%$ & 36 \\
plenamente) & &
\end{tabular}

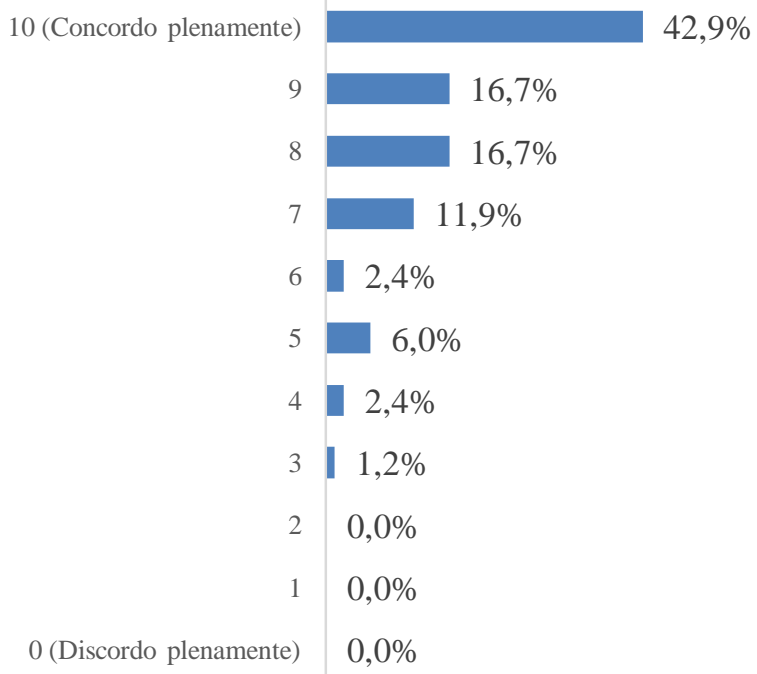

Fonte: Do autor.

Nota: * $\mathrm{N}^{\mathrm{o}}$ de Respondentes: 84; $\mathrm{N}^{\mathrm{o}}$ Não Respondentes: 11.

4.3 Vossa Excelência julga o seu conhecimento tácito profissional como privado (como pertencente somente a Vossa Excelência) ou público? 
Tabela 29 - Natureza do conhecimento Gráfico 26 - Natureza do conhecimento tácito tácito*

\begin{tabular}{c|c|c}
\hline $\begin{array}{c}\text { Frequência de } \\
\text { interação }\end{array}$ & Percentual & Quantitativo \\
\hline Privado & $20,2 \%$ & 17 \\
Público & $79,8 \%$ & 67 \\
\hline
\end{tabular}

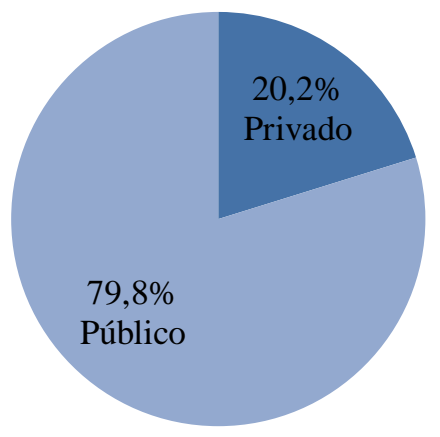

Fonte: Do autor.

Nota: *No de Respondentes: 84; Nº Não Respondentes: 11.

Percebe-se um volume expressivo de respondentes $(79,8 \%)$ posicionando-se como favorável ao entendimento de que o conhecimento tácito próprio é público. Uma parcela de 20,2\% dos juízes acredita, contudo, que é privado o conhecimento tácito.

\subsection{O EMPREGO DA UNIDADE DE MEDIDA}

\subsubsection{Identificação das variáveis explicativas (VE)}

Como se viu (item 3.4.5), o modelo Beta reduzido foi empregado para gerar um subconjunto de oito variáveis, as variáveis explicativas (VE) do fenômeno.

Essas variáveis foram selecionadas levando-se em conta o nível de significância ( $p$ valor) menor que $5 \%(<0,05)$ de cada variável hipotética $(\mathrm{VH})$, de acordo com o método proposto. Os dados expressos na Tabela 30 mostram os resultados obtidos.

A estimativa de impacto indica qual a força do impacto das variáveis sobre o indicador. Alguns p-valor encontrados no modelo reduzido alcançam valores maiores que 0,05 . Tais valores, entretanto, foram mantidos, pois fazem parte de um grupo de variáveis, por exemplo, 'Tempo de magistratura' e 'Região'. Caso os valores $(>0,05)$ fossem desconsiderados, levaria a variável como um todo ao descarte, o que retiraria da análise variáveis significativas.

'Tempo de JF' significa a quantidade de tempo que o juiz tem trabalhado na Justiça Federal. 'Tempo de JEF' significa a quantidade na Justiça Federal, porém, como juiz em 
$\mathrm{JEF}^{83}$. Os períodos, 'Tempo de JF $<5$ anos' e o 'Tempo de JEF $<1$ ano' serviram como base para o método. 'Tempo de JF (< de 5)', 'Tempo de JEF (< de 1 ano)' e 'A qual região da Justiça Federal pertence sua Vara/TR (Primeira Região)' foram tomados como base, ou seja, apresentam-se como um valor referencial. Por exemplo, o juiz com 'Tempo de JF (Mais de 15 anos) - valor positivo, tende a compartilhar mais do que o juiz com 'Tempo de JF $(<$ de 5 anos)' - base. Todavia, os juízes com 'Tempo de JF (De 5 a 9 anos) e os com 'Tempo de JF (De 10 a 15 anos) - valores negativos, têm uma menor propensão a compartilhar do que o juiz com 'Tempo de JF ( $<$ de 5 anos)' - base.

Tabela 30 - Impactos das variáveis sobre o indicador, segundo o Modelo (Beta Reduzido)

\begin{tabular}{|c|c|c|c|c|}
\hline Variável & $\begin{array}{l}\text { Estimativa } \\
\text { do impacto }\end{array}$ & \begin{tabular}{|c|} 
Erro \\
Padrão
\end{tabular} & $\begin{array}{c}\text { Valor } \\
\mathbf{Z}\end{array}$ & $\begin{array}{c}P- \\
\text { valor }\end{array}$ \\
\hline (Intercepto) & $-2,437$ & 0,528 & $-4,619$ & 0 \\
\hline Idade & 0,023 & 0,01 & 2,219 & 0,026 \\
\hline Tempo de JF (< de 5 anos $)$ & base & & & \\
\hline Tempo de JF (De 5 a 9 anos) & $-0,385$ & 0,184 & $-2,086$ & 0,037 \\
\hline Tempo de JF (De 10 a 15 anos) & $-0,128$ & 0,184 & $-0,693$ & 0,488 \\
\hline Tempo de JF (Mais de 15 anos) & 0,17 & 0,283 & 0,6 & 0,549 \\
\hline Tempo de JEF (< de 1 ano) & base & & & \\
\hline Tempo de JEF (De 1 a 2 anos) & $-0,371$ & 0,191 & $-1,938$ & 0,053 \\
\hline Tempo de JEF (De 3 a 5 anos) & $-0,16$ & 0,188 & $-0,852$ & 0,394 \\
\hline Tempo de JEF (Mais de 5 anos) & $-0,075$ & 0,177 & $-0,421$ & 0,674 \\
\hline $\begin{array}{l}\text { A qual região da Justiça Federal pertence sua Vara/TR (Primeira } \\
\text { Região) }\end{array}$ & base & & & \\
\hline $\begin{array}{l}\text { A qual região da Justiça Federal pertence sua Vara/TR (Segunda } \\
\text { Região) }\end{array}$ & 0,044 & 0,185 & 0,239 & 0,811 \\
\hline $\begin{array}{l}\text { A qual região da Justiça Federal pertence sua Vara/TR (Terceira } \\
\text { Região) }\end{array}$ & $-0,214$ & 0,185 & $-1,155$ & 0,248 \\
\hline $\begin{array}{l}\text { A qual região da Justiça Federal pertence sua Vara/TR (Quarta } \\
\text { Região) }\end{array}$ & $-0,435$ & 0,165 & $-2,636$ & 0,008 \\
\hline $\begin{array}{l}\text { A qual região da Justiça Federal pertence sua Vara/TR (Quinta } \\
\text { Região) }\end{array}$ & 0,023 & 0,159 & 0,145 & 0,885 \\
\hline $\begin{array}{l}\text { Grau de intensidade da participação presencial em eventos de } \\
\text { natureza interativa }\end{array}$ & 0,194 & 0,024 & 7,974 & 0 \\
\hline Participa de alguma rede social que trate de temas profissionais (Sim) & $-0,362$ & 0,128 & $-2,825$ & 0,005 \\
\hline $\begin{array}{l}\text { Emprega alguma tecnologia de comunicação particular para } \\
\text { compartilhamento de conhecimento tácito, ideias, experiências, } \\
\text { expertise, habilidades, entendimentos jurídicos, modelos e outros } \\
\text { conteúdos mentais (Sim) }\end{array}$ & 0,327 & 0,13 & 2,526 & 0,012 \\
\hline $\begin{array}{l}\text { Nível de concordância com a afirmação "Concordo que a mobilidade } \\
\text { do conhecimento tácito é imprescindível aos juízes para o melhor } \\
\text { exercício de sua atividade judiciária" }\end{array}$ & 0,125 & 0,032 & 3,88 & 0 \\
\hline
\end{tabular}

Fonte: Do autor e Odds\&Actions.

Para ilustrar os resultados obtidos na tabela acima, o gráfico seguinte foi elaborado. Os impactos das variáveis sobre o indicador (negativos e positivos) estão registrados no eixo X.

\footnotetext{
${ }^{83}$ Varas JEF/JEF Adjunto ou Turma Recursal.
} 
Gráfico 27 - Impactos das variáveis sobre o indicador, segundo o Modelo (Beta Reduzido)

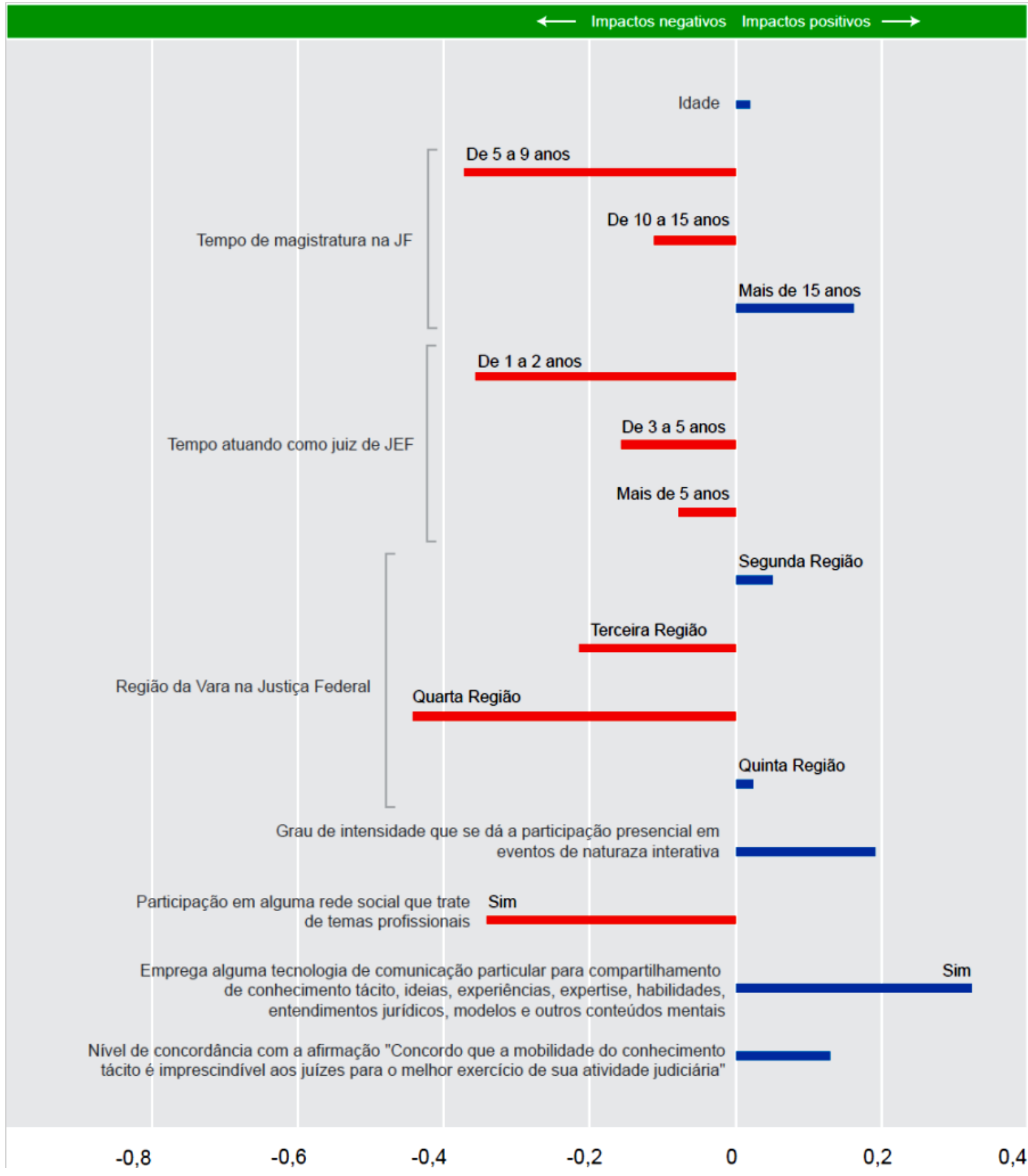

Fonte: Do autor e Odds\&Actions.

Para melhor apresentação, as oito variáveis explicativas foram divididas em três grupos. O primeiro grupo traz as VE iniciais (Tabela 31). O segundo, as VE relacionadas ao tempo do juiz na Justiça Federal e no JEF (Tabela 32). O terceiro é composto de apenas uma VE (Tabela 33) e apresenta a VE relacionada à Região onde o juiz estava atuando. 


\subsubsection{Grupo das variáveis explicativas (VE) iniciais}

A tabela 31 mostra as variáveis, 'Idade' $(1.4)^{84}$; 'Frequência de participação presencial em eventos de natureza interativa' (3.4); 'Rede social' (3.6); 'Tecnologia particular de comunicação' (3.7); e 'Concordância que o compartilhamento é indispensável para exercício da atividade judiciária' (4.2) e as correspondentes estimativas de impactos sofridos pelo indicador.

Tabela 31 - Grupo das variáveis explicativas (VE) iniciais

\begin{tabular}{|c|c|c|}
\hline Variáveis & Impacto & P-valor \\
\hline Idade & 0,023 & 0,026 \\
\hline $\begin{array}{l}\text { Frequência de participação presencial em eventos de natureza interativa (conferências, } \\
\text { seminários) }\end{array}$ & 0,194 & 0,000 \\
\hline Rede social (os que marcaram a resposta 'sim') & $-0,362$ & 0,005 \\
\hline Tecnologia particular de comunicação (smartphone etc) & 0,327 & 0,012 \\
\hline $\begin{array}{l}\text { Concordância de que o compartilhamento é imprescindível para exercício da atividade } \\
\text { judiciária }\end{array}$ & 0,125 & 0,000 \\
\hline
\end{tabular}

Fonte: Do autor.

A variável 'Idade' apontou um valor positivo de pequeno impacto $(0,023)$. Apesar do pouco valor, por ser positiva, significa que quanto maior a idade do juiz, maior será a sua propensão em compartilhar. Tal resultado está em consonância com que apresentou Holste e Fields (2009) ao indicar uma relevante relação entre idade e disposição em compartilhar o conhecimento tácito.

A variável 'frequência de participação presencial em eventos de natureza interativa' de valor 0,194 , conferiu maior propensão de compartilhamento que a idade. Isso demonstrou que a frequência em eventos desse tipo leva os juízes a apresentar uma disposição maior em compartilhar conhecimento tácito.

A variável 'Rede social' (os que marcaram a resposta 'sim'), apesar de identificar um valor expressivo $(-0,362)$, sinalizou como negativo o impacto sobre o indicador. Os juízes que responderam afirmativamente à pergunta, isto é, que pertencem a uma rede social técnica, manifestaram-se contrários ao compartilhamento.

A variável 'Tecnologia particular de comunicação (smartphone etc.)' impactou positivamente o compartilhamento com valor considerável $(0,327)$. Isso representa uma disposição favorável a compartilhar por parte dos juízes que se utilizam dessa ferramenta.

\footnotetext{
${ }^{84}$ Os números entre parênteses referem-se às perguntas do questionário.
} 
A variável 'Concordância que o compartilhamento é indispensável para exercício da atividade judiciária' detectou razoável impacto positivo sobre o índice de compartilhamento $(0,125)$. Tal valor indica serem viáveis ações pró-compartilhamento de conhecimento tácito.

\subsubsection{Grupo das variáveis explicativas (VE) relacionadas ao tempo de serviço}

A tabela 32 apresenta as variáveis relacionadas com o período de tempo em que o juiz exerceu (na Justiça Federal e nos JEF) o seu ofício desde a sua nomeação para o cargo até a data da pesquisa.

Tabela 32 - Variáveis relativas ao tempo como juiz e impactos sobre o indicador ${ }^{85}$

\begin{tabular}{|l|c|c|}
\hline Variáveis & Impacto & P-valor \\
\hline Tempo de JF $<5$ anos & base & base \\
\hline Tempo de JF 5 - 9 anos & $\mathbf{- 0 , 3 8 5}$ & 0,037 \\
\hline Tempo de JF 10 - 15 years & $\mathbf{- 0 , 1 2 8}$ & $0,488^{*}$ \\
\hline Tempo de JF $>15$ years & 0,170 & $0,549^{*}$ \\
\hline Tempo de JEF < 1 year & base & base \\
\hline Tempo de JEF 1 - 2 years & $\mathbf{- 0 , 3 7 1}$ & 0,053 \\
\hline Tempo de JEF 3 - 5 years & $\mathbf{- 0 , 1 6 0}$ & $0,394^{*}$ \\
\hline Tempo de JEF > 5 years & $\mathbf{- 0 , 0 7 5}$ & $0,674 *$ \\
\hline
\end{tabular}

Fonte: Do autor.

Na variável 'Tempo de JF', o juiz antes de completar cinco anos ${ }^{86}$ apresenta maior propensão a compartilhar que nos períodos de cinco a nove $(5-9)$ e de dez a quinze $(10-15)$ anos. Tendo em conta os juízes com mais de cinco anos de tempo de Judiciário, o gráfico mostra um declínio do impacto negativo e uma reversão positiva. Assim, após os anos iniciais, quanto maior for o tempo de juiz no Judiciário, maior é a propensão em compartilhar. A variável 'Tempo de JEF' segue o mesmo padrão da variável 'Tempo de JF', conforme a tabela demonstra.

O modelo de Tonet e Paz (2006) propiciou ao pesquisador compreender melhor o valor do indicador sob impacto da variável “Tempo". O compartilhamento para juízes em seus anos iniciais ('Tempo de JF' ou 'Tempo de JEF') acusou valores maiores que os anos posteriores. O modelo dos autores admite que na fase de "iniciação" o indivíduo procura

\footnotetext{
${ }^{85}$ Apesar de o modelo desconsiderar os fatores que apresentaram p-valor maior que 5\%, neste caso, faixas de anos com p-valor maior que 0,05 foram considerados, a fim de que faixas relevantes ['Tempo de JF 5 - 9 anos ' e 'Tempo de JEF $1-2$ years $^{\text {' }] ~ q u e ~ t r a z e m ~ p-v a l o r ~ m e n o r ~ q u e ~ 5 \% ~ f o s s e m ~ l e v a d a s ~ e m ~ c o n t a, ~ c o n f o r m e ~ o ~ m e ́ t o d o . ~}$ ${ }^{86} \mathrm{O}$ período $(<5)$ anos foi tido como base. Dessa forma, lê-se que nos períodos de $(5-9)$ anos e $(10$ - 15) anos cujo $\mathrm{i}_{\mathrm{CCT}}$ é negativo a propensão de compartilhamento é menor que o período $(<5)$ anos. Este período, entretanto, apresenta propensão menor que o período (> 15) anos onde o índice alcança o valor de 0,170 .
} 
localizar fontes onde o conhecimento pode ser recuperado, ocorrendo uma dinâmica de busca e troca do conhecimento.

\subsubsection{Variável Posição Geográfica}

Os resultados relativos à posição geográfica (Região) e impactos sobre o indicador à Região onde o JEF está localizado são mostrados abaixo.

Tabela 33 - Variáveis relativas à posição geográfica (Região) e impactos sobre o indicador

\begin{tabular}{|l|c|c|}
\hline Variáveis & Impato & P-valor \\
\hline $\begin{array}{l}\text { Região } 1 \text { (Centro-Oeste, Norte, } \\
\text { parte do Nordeste) }\end{array}$ & base & base \\
\hline Região 2 (parte do Sudeste) ${ }^{87}$ & 0,044 & 0,811 \\
Região 3 (parte do Sudeste) & $\mathbf{- 0 , 2 1 4}$ & 0,248 \\
Região 4 (Sul) & $\mathbf{- 0 , 4 3 5}$ & 0,008 \\
Região 5 (parte do Nordeste) & $\mathbf{0 , 0 2 3}$ & 0,885
\end{tabular}

Fonte: Do autor.

A variável 'Região' assinala índices de propensão ao compartilhamento distintos entre as regiões, conforme a tabela acima. Região 1 (Centro-Oeste, Norte, parte do Nordeste) / R1 serviu como base à modelagem ${ }^{88}$. Região 2 (parte do Sudeste) / R2 mostra um discreto valor, embora positivo (0,044). Região 3 (parte do Sudeste) / R3 e a Região 4 (Sul) / R4 revelam impactos negativos, porém R4 com maior força; respectivamente, -0,214 e -0,435. Região 5 (parte do Nordeste) / R5 sinaliza um valor positivo, mas de baixo impacto $(0,023)$. As Regiões R3 e R4, segundo seus valores, apontam impactos negativos sobre o indicador com menores graus de propensão se comparados a R1 que exibe menores possibilidades de propensão a compartilhar que R2 e R5.

\subsubsection{Estabelecimento de perfil de juízes com base no indicador}

O indicador atribuiu um valor numérico referente à propensão de cada juiz a compartilhar, estivesse ele/ela na amostra ou não. Esta funcionalidade pode permitir reunir juízes em grupos de semelhantes valores de propensão (em quartis, por exemplo, como na

${ }^{87}$ A região Sudeste foi dividida em duas Regiões em razão de englobar os estados do Rio de Janeiro e São Paulo, onde o volume de ações é muito alto.

${ }^{88}$ A Região 1 foi tida como base pelo modelo. Dessa forma, lê-se que nas Regiões R3 e R4, onde o compartilhamento apresenta valor negativo, os juízes demonstram uma propensão ao compartilhamento menor que na R1. Em contrapartida, os juízes da R1 mostram propensão menor que os da R5 e R2. 
Figura 12). Na figura abaixo, os valores do indicador apresentam-se no eixo $\mathrm{X}$. O eixo $\mathrm{Y}$ (Density) indica a quantidade de juízes (da amostra) a cada valor do indicador.

Gráfico 28 - Curva de densidade relativa aos indicadores de propensão ao compartilhamento (juízes da amostra)

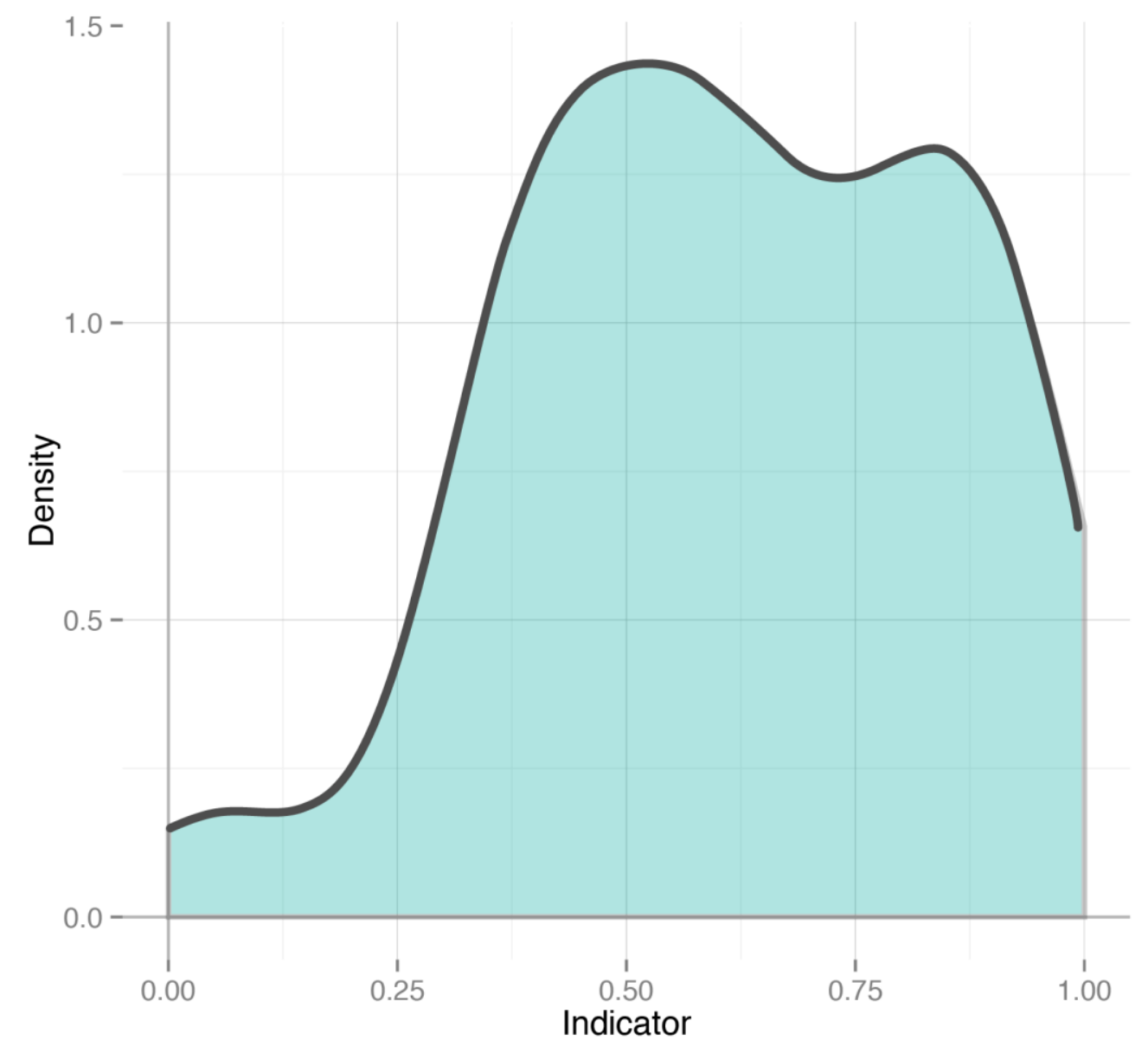

Fonte: Do autor e Odds \& Actions.

Dessa forma, graus de compartilhamento por quartis podem servir como referência para possíveis classificações de juízes quanto ao grau de propensão a compartilhar.

Quadro 14 - Intervalos classificadores para a definição dos graus de compartilhamento

\begin{tabular}{|c|c|c|}
\hline Intervalo (anyi) & Quartil & Grau de compartilhamento \\
\hline$(0 ; 0,25)$ & $1^{\text {o }}$ quartil & baixo \\
\hline$(0,26 ; 0,5)$ & $2^{\text {o }}$ quartil & moderado-baixo \\
\hline$(0,51 ; 0,75)$ & $3^{\text {o }}$ quartil & moderado-alto \\
\hline$(0,76 ; 1,00)$ & $4^{\text {o }}$ quartil & alto \\
\hline
\end{tabular}

Fonte: Do autor. 
4.2.1.5 Atribuição de valor numérico à propensão individual (juízes fora da amostra)

Outro resultado da pesquisa foi o indicador $\left(\mathrm{i}_{\mathrm{CCT}}\right)$ servir como classificador individual do grau de propensão a compartilhar de juízes.

Para testar esta funcionalidade, cinco juízes de JEF escolhidos pelo autor (fora da amostra) preencheram o questionário (Apêndice E), adaptado às variáveis explicativas (VE), segundo o modelo de regressão Beta (reduzido).

Após serem coletados os dados, os resultados obtidos foram, como expressa a Tabela 34:

Tabela 34 - Indicadores dos juízes selecionados fora da amostra

\begin{tabular}{|c|c|}
\hline Indivíduos & $\mathbf{i}_{\mathbf{C C T}}$ (anyi) \\
\hline Juiz 1 & 0,46 \\
\hline Juiz 2 & 0,91 \\
\hline Juiz 3 & 0,66 \\
\hline Juiz 4 & 0,77 \\
\hline Juiz 5 & 0,66 \\
\hline
\end{tabular}

Fonte: Do autor.

Conforme os intervalos classificadores para a definição dos graus de compartilhamento do conhecimento tácito (Quadro 13), pode-se atribuir os seguintes níveis de propensão a compartilhar:

Tabela 35 - Graus de compartilhamento calculados para juízes selecionados fora da amostra, segundo o $\mathbf{i}_{\mathrm{CCT}}$

\begin{tabular}{|c|c|}
\hline Indivíduos & $\begin{array}{c}\text { Grau de } \\
\text { compartilhamento }\end{array}$ \\
\hline Juiz 1 & Moderado-baixo \\
\hline Juiz 2 & Alto \\
\hline Juiz 3 & Moderado-alto \\
\hline Juiz 4 & Alto \\
\hline Juiz 5 & Moderado-alto \\
\hline
\end{tabular}

Fonte: Do autor. 


\section{ANÁLISES E CONCLUSÕES}

O diálogo não é um assunto de luxo intelectual, ele diz respeito à criação, à criatura; e o homem de quem falo, o homem de quem falamos, é isto, é criatura, trivial e insubstituível (BUBER, 1982, p. 71).

O objetivo do estudo foi alcançado. Das 23 variáveis hipotéticas (VH), propostas segundo uma revisão da literatura associada à experiência do autor, oito foram identificadas como explicativas do fenômeno do compartilhamento do conhecimento tácito em ambiente dos Juizados Especiais Federais (JEF) do Brasil, na concepção de seus juízes. São elas: idade; tempo de Justiça Federal (como juiz); tempo de JEF (como juiz); Região da Justiça Federal; participação (ou não) em eventos de natureza interativa; participação em redes sociais de caráter técnico; emprego de aparelhos de comunicação privados (smartphones, tablets, etc.); concordância (ou não) que o compartilhamento é imprescindivel aos trabalhos do juiz.

O tema da pesquisa, o conhecimento, vem ocupando o centro de estudos e pesquisas há algum tempo. Por tal razão, não se encontrou dificuldades em se colher trabalhos que tratassem do conhecimento tácito e do compartilhamento desse conhecimento.

O entendimento que se observou na revisão de literatura foi o de que as organizações encontram-se transitando de um modelo tradicional aferrado em ativos físicos e tangíveis para outro, onde o conhecimento, especialmente o tácito, é tratado como um ativo valioso e gerador de riqueza.

Nessa trajetória, verificaram-se referências onde o compartilhamento do conhecimento tácito foi relacionado a uma gama de vetores organizacionais, desde compreendê-lo como um fator de inovação até como componente estratégico para alavancagem do desempenho organizacional.

Visto por uns como difícil de transferir, o conhecimento tácito é aceito por outros como componente de fluxos de comunicação, onde diálogos deixam de ser meras conversas e transformam-se em potentes canais de transmissão de conhecimento.

Esse profundo mergulhar em trabalhos teóricos e práticos permitiu ao autor gerar seus próprios conceitos. $\mathrm{O}$ autor compreendeu o conhecimento tácito como um produto mental intangível, passível de compartilhamento e em constante reformulação. Composto por elementos abstratos (ideias, raciocínios, know-how, habilidades, alegorias, modelos, constructos, insights, experiências, lembranças, sons, imagens, odor, gosto, tato, entre outros) é capaz de gerar novos conhecimentos e práticas inovadoras. O compartilhamento foi assumido como um fenômeno de intercâmbio interpessoal descritível e mensurável. 
Representou a interação de fluxos de conhecimento tácito estabelecida entre pessoas. Pode ocorrer dentro das organizações ou entre estas, requer um ambiente de confiança social e propicia a incorporação de novos conteúdos com ganhos multilaterais de natureza agregadora.

Nesse caminhar, variáveis que potencialmente explicassem o fenômeno do compartilhamento do conhecimento tácito foram colhidas. Essas variáveis tratadas como hipotéticas (VH) foram agrupadas em seis dimensões: Pessoal, Acadêmica, Funcional, Organizacional, Geográfica e Social. Tais dimensões pareciam poder englobar as $23 \mathrm{VH}$ que sustentariam a hipótese que presumidamente influenciavam o fenômeno do compartilhamento do conhecimento tácito.

Essas variáveis povoaram as hipóteses, divididas em central e derivadas, que de plano conceberam um fluxo comunicativo entre os juízes e determinados sujeitos que compuseram uma rede de compartilhamento. Nessa arquitetura social, o juiz foi estabelecido como hub (centro de conexões) e os seus pares (outros juízes), os agentes externos (os ASJ) e a sua equipe de trabalho (os servidores) como "extremidades".

É desse arranjo que nascem as variáveis interativas (VInt) que subsidiaram a criação da unidade de medida que expressasse a propensão dos juízes em compartilhar seus conhecimentos tácitos, assim como o metro mensura distâncias e o litro, volumes. Essa unidade foi batizada por 'anyi' em homenagem a Michel Polanyi.

Criada a unidade de medida, necessitava-se de algo que pudesse verificar, segundo as variáveis apresentadas na hipótese (e por isso, hipotéticas), alterações na propensão ao compartilhamento. As variáveis que significativamente impactassem o indicador poderiam ser tomadas como variáveis explicativas do fenômeno, objetivo da pesquisa.

Essa foi a ideia preliminar que levou à construção de um método para a identificação das variáveis explicativas do compartilhamento. As etapas resultantes foram: (1) Identificação do agente central; (2) Explicitação da Rede de Compartilhamento (RC); (3) Mapeamento das possíveis variáveis explicativas, estabelecimento das hipóteses e elaboração do instrumento de coleta de dados e informações (o questionário); 4) Criação de uma unidade de medida capaz de mensurar a propensão ao compartilhamento do conhecimento tácito; (5) Estimação dos impactos das variáveis hipotéticas $(\mathrm{VH})$ sobre do indicador e identificação das variáveis explicativas (VE).

O método lançou mão de várias ferramentas estatísticas. Dentre elas: análise de dispersão, correlação de variáveis, Análise de Componente Principal (ACP) e modelo de regressão Beta e Beta reduzido. 
Apesar das dificuldades em recolher os dados e as informações dos juízes, dado o escasso tempo e o volume considerável de demandas a serem solucionadas por estes profissionais, foram colhidos 95 questionários pela plataforma empregada (surveymonkey). A amostra planejada foi de 105 juízes federais de JEF.

Com a aplicação do método, os seguintes resultados apresentaram-se:

(I) a caracterização os sujeitos amostrais, segundo as variáveis hipotéticas (VH) incorporadas pelas hipóteses;

(II) a proposição de uma nova unidade de medida de propensão ao compartilhamento de conhecimento tácito (anyi), não identificada na literatura;

(III) a formulação de um indicador numérico que mensurasse a propensão ao compartilhamento do conhecimento tácito, da mesma forma, não identificada na literatura;

(IV) a identificação das variáveis explicativas (VE) do fenômeno do compartilhamento, acima já citadas;

(V) verificação do valor e da positividade do impacto das VE sobre o indicador, o que permite verificar onde se atuar de forma mais intensa para aumentar o compartilhamento;

(VI) estimação da propensão individual de um juiz compartilhar o seu conhecimento tácito, o que pode auxiliar a administração judiciária a estabelecer mecanismos de intercâmbio. Uma resposta positiva foi encontrada quando se testou juízes fora da amostra. Com a aplicação do o questionário (Apêndice E), elaborado com questionamentos baseados nas variáveis explicativas identificadas pelo modelo de regressão Beta (reduzido). Os resultados provaram ser o modelo eficaz para a representação do valor numérico da propensão a compartilhar (Tabela 34). Em ambos os casos (dentro ou for a da amostra), foi possível avaliar a propensão.

(VII) estabelecimento de agrupamentos de juízes com graus de compartilhamento semelhantes e distintos (de forma regional ou em âmbito nacional), com possíveis combinações para aprimoramento de todos;

(VIII) segmentação dos juízes em faixas de propensão: $(0-0,25)$, grau de compartilhamento baixo; $(0,26-0,50)$, moderado-baixo; $(0,51-0,75)$, moderadoalto; e $(0,76-1,00)$, alto (Gráfico 28 - Curva de Densidade). Essa divisão pode tornar-se um instrumento capaz de subsidiar ações de desenvolvimento do 
capital intelectual dos juízes e de sua rede de compartilhamento. Por meio dessa curva, pôde-se perceber uma possível divisão de juízes em quartis de propensão a compartilhar, onde se viu uma baixa concentração no primeiro quartil; uma concentração média nos segundo e quarto; e uma alta, no terceiro. Há espaço, assim, para o desenvolvimento de ações, projetos e políticas que busquem deslocar a massa de juízes de graus inferiores para superiores.

A análise das variáveis explicativas levou a algumas significativas conclusões:

a) A idade impactou positivamente o indicador, embora de forma discreta. Isso indica que quanto maior for a idade do juiz, maior é a propensão a compartilhar.

b) A frequência de participação presencial em eventos de natureza interativa (conferências, seminários) esteve positivamente associada ao compartilhamento. Isso demonstra que a promoção de novos eventos dessa natureza podem contribuir para um aumento do compartilhamento do conhecimento.

c) O emprego de tecnologia particular de comunicação (smartphone etc.) estimulou o indicador e sinalizou que a tecnologia móvel emprestou certa capacidade ao juiz em compartilhar mais.

d) O fato de ter havido 'concordância de que o compartilhamento é indispensável para exercício da atividade judiciária' sinalizou que os juízes que responderam 'sim' mostraram-se mais propensos a compartilhar.

e) A participação em redes sociais levou o indicador a valor expressivo, embora negativo, em outras palavras, o fato de o juiz pertencer a uma rede social de caráter técnico mostrou uma tendência em compartilhar menos.

f) Quanto ao 'tempo de JF' e 'Tempo de JEF', observou-se que nos anos iniciais o juiz possui uma propensão mais alta do que nos anos posteriores. Durante os anos seguintes, o impacto negativo (presente e de valor não inexpressivo) tende a decrescer. De forma geral, pode-se dizer que após o período inicial como juiz, quanto mais avança o tempo, maior é a propensão em compartilhar.

g) A análise geográfica indicou que em cada Região o juiz apresentou um comportamento distinto. Como disposição referente ao compartilhamento, tem-se a R2 (Rio de Janeiro e Espírito Santo) com maior impacto sobre o indicador (maior propensão a compartilhar), seguida da R5 (Estados do Nordeste, exceto Bahia, Piauí e Maranhão), R1 (Região Norte, Centro-Oeste, com exceção de Mato Grosso do Sul e Tocantins, somados os Estados da Bahia, Piauí, Maranhão e o 
Distrito Federal), R3 (São Paulo e Mato Grosso do Sul) e R4 (Paraná, Santa Catarina e Rio Grande do Sul).

O alcance dos resultados e das conclusões pode também ser traduzido pela possibilidade de:

1) dar a conhecer aos juízes seus próprios indicadores e permitir analisá-los frente a outros;

2) enriquecer iniciativas referentes a contatos interativos com detalhes antes desconhecidos;

3) estimular o desenvolvimento de ações relativas ao estreitamento de interações humanas;

4) fomentar a elaboração de estratégias, políticas e projetos que estabeleçam bases ou suportem ações voltadas ao compartilhamento.

Dentre essas ações, vislumbram-se as capazes de dar maior fluidez ao conhecimento tácito dos magistrados na interação com sua rede de compartilhamento.

Por fim, o indicador torna-se uma possível ferramenta a ser empregada nos três níveis organizacionais. Como exemplos, pode-se citar, no nível operacional: o indicador, ao revelar o valor da propensão individual para o compartilhamento, provê a faculdade de o juiz, (a) alterar o seu procedimento ou uma rotina na sua unidade de trabalho, (b) buscar uma mudança cultural quanto à importância do ato de compartilhar e (c) incentivar o uso mais intenso de tecnologias móveis de comunicação.

No nível gerencial, o indicador apresenta mensurações capazes de servir como referência a gestores de Recursos Humanos. Na proposição de grupos de trabalho ou Comunidades de Prática, há a possibilidade de compor tais arranjos sociais com juízes de maior e menor índice de propensão ao compartilhamento do conhecimento tácito.

No nível estratégico, o indicador permite análises de maior amplitude sobre as variáveis que apresentaram expressivos impactos, como, por exemplo, avaliar por que determinadas regiões trazem impactos negativos e outras, positivos.

Essa mudança, contudo, pode abranger toda a organização em seus três níveis. $\mathrm{Na}$ Vara, o juiz cria essa atmosfera de nova cultura de compartilhamento de conhecimento tácito. No âmbito dos TRF, as Secretarias de Recursos Humanos buscam a promoção de uma mudança cultural que fomente maior troca de conhecimentos tácitos, com a inserção desse tema no processo de planejamento estratégico corporativo. 
Assim, a explicação provisória do fenômeno, como tem de ser na ciência, não deixou, contudo, de apresentar uma contribuição para o aprimoramento da resolução dos processos judiciais em JEF. Identificadas a variáveis, torna-se viável o melhor uso do conhecimento e a geração de novos, capazes de proporcionar aos JEF rotinas que ofereçam um aumento de eficácia e de celeridade.

Concernente às limitações do estudo, o método carece de mais testes, comprovações e interpretações, tendo em vista que estes são os primeiros resultados.

Outro limite apontado reside no fato de o indicador ter sido construído sob a perspectiva de juízes lotados em JEF, com rotinas, níveis e formas de interação e circunstâncias distintas das demais varas comuns da Justiça Federal ou de outra justiça, como eleitoral, militar, estadual ou trabalhista. Pelo fato de a pesquisa ter sido desenvolvida no Brasil, esse aspecto pode trazer restrições se sua aplicação for desejada em outro país.

De forma pontual, na pergunta (3.8 Quando Vossa Excelência compartilha conhecimento tácito, este acontece mais frequentemente com?), não foi oferecida uma opção 'outros', a fim de que os juízes pudessem informar outro sujeito com o qual também compartilhassem. Contudo, no campo de 'respostas abertas' ao final do trabalho, nenhum juiz, entre opiniões e críticas de diversas naturezas, considerou essa ausência ou acusou outro sujeito com o qual pudesse estabelecer de forma frequente o compartilhamento.

Futuras pesquisas podem ter como pergunta investigativa: (1) como se comporta o juiz no seu compartilhamento ao longo de sua idade e ao longo dos anos da vida laboral de maneira mais pormenorizada, com a proposta de uma curva de representação 'idade $\mathrm{x}$ índice de compartilhamento' ou 'tempo de JF/JEF x índice de compartilhamento', dentro de certas condições pré-estabelecidas?; (2) que tipo de variações de compartilhamento ocorre ou não quando de alteram as regiões onde está lotado o juiz e por quê?; (3) quais são as razões pelas quais aquele juiz que participa de redes sociais técnicas tende a partilhar menos?; (4) por que o emprego de aparelhos móveis inteligentes de comunicação gera aumento do compartilhamento?; (5) por que o grupo de juízes que esposa do entendimento de que 'o compartilhamento é indispensável para exercício da atividade judiciária' espelha um positivo grau de partilha?; (6) é aplicável o indicador em outros segmentos da Justiça como a Eleitoral, Trabalhista, Estadual, entre outros?. A última proposição para estudos futuros (7) fica por conta da verificação da possibilidade de transformar o indicador em um modelo de identificação de variáveis explicativas ao compartilhamento de conhecimento tácito. 
Por fim, propõe-se o delineamento abaixo que pretende resumir a pesquisa de forma esquemática.

Figura 17 - Resumo esquemático da pesquisa

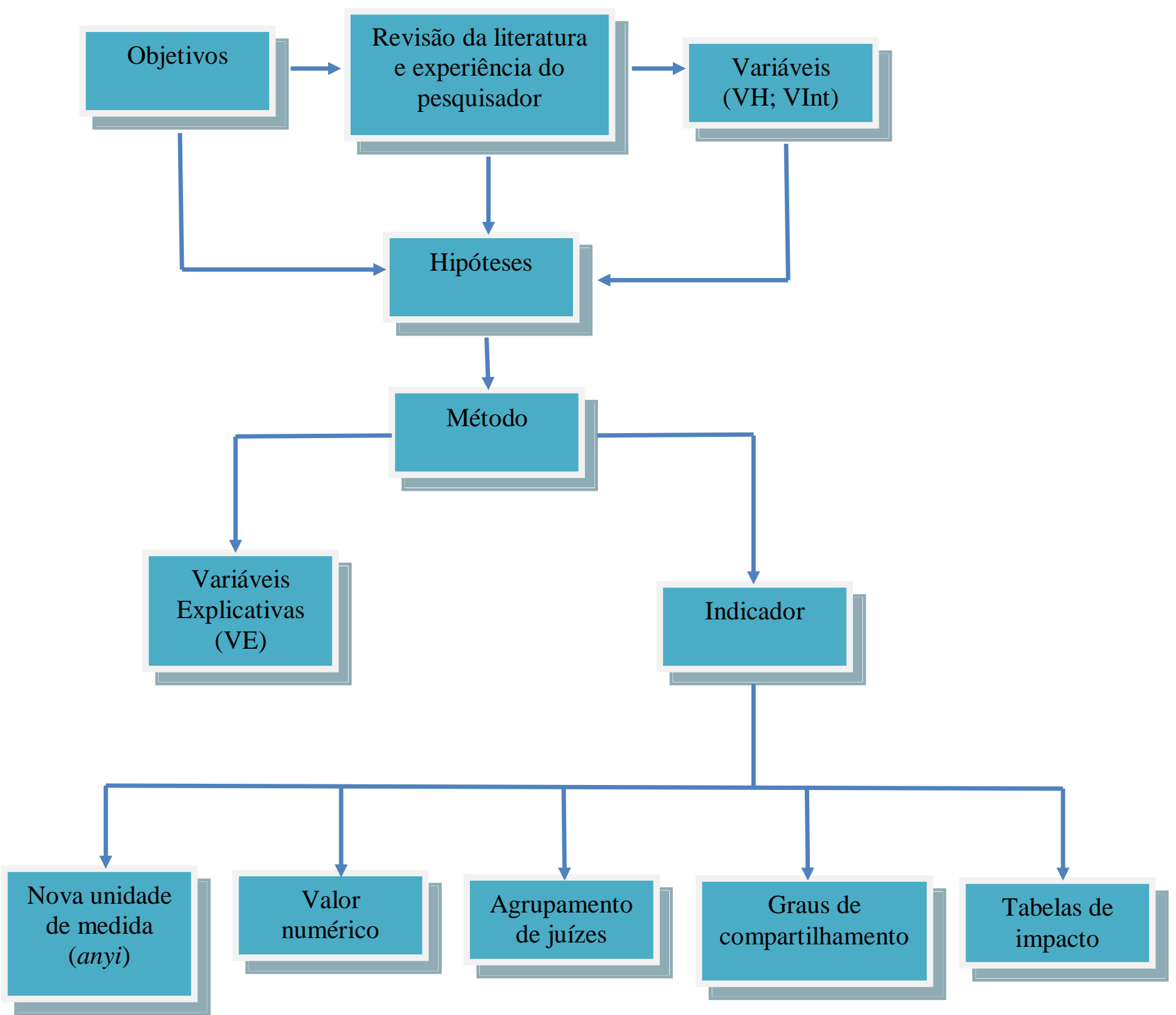

Fonte: Do autor. 


\section{REFERÊNCIAS}

ABBAGNANO, N. Dicionário de Filosofia. 5. ed. São Paulo: Martins Fontes, 2007.

AFONSO, C. W.; CALADO, L. R. Organizações intensivas de conhecimento e sua relação com as estratégias de marketing. R. Adm., São Paulo, v. 46, n. 2, p. 150-160, abr./maio/jun. 2011 .

ALAVI, M; LEIDNER, D. E. Knowledge Management and Knowledge Management Systems: Conceptual Foundations and Research Issues. Mis Quaterly, v. 25, n. 1, mar., 2001.

ALBERTI, A.; BERTUCCI, G. Innovation in governance and public administration: key issues and perspective. In: UNITED NATIONS. Innovations in Governance in the Middle East, North Africa, and Western Balkans: Making Governments Work Better in the Mediterranean Region. New York: Department of Economic and Social Affairs, 2007.

ALVARENGA NETO, R. C. D. Gestão do conhecimento ou gestão de organizações da era do conhecimento? Um ensaio teórico-prático a partir de intervenções na realidade brasileira.

Perspectivas em Ciência da Informação, v.12, n. 1, p. 5-24, jan./abr., 2007.

ALVARES, L. M. A. de R. Telecentros de informação e negócios como veículo de educação corporativa nas microempresas e empresas de pequeno porte. 2010 . Tese (doutorado)- PPGCINF, UnB, Brasília, 2010.

AMABILE, T. M. How to kill creativity. Harvard Business Review, v. 76, n. 5, p. 76-87, 1998.

AMIT, R.; SCHOEMAKER. P. J. H. Strategic assets and organizational rent. Strategic Management Journal, v. 14, p. 33-46, 1993.

ANDRIGHI, Fátima Nancy. A democratização da Justiça. Revista CEJ, Brasília, v. 1, n. 3, p. 70-75, set./dez. 1997.

ARANHA, M. L. A. Filosofando: introdução à Filosofia. 2. ed. rev. atual. - São Paulo: Moderna, 1993.

ARDICHVILI, A.; PAGE, V.; WENTLING, T. Motivation and barriers to participation in virtual knowledge-sharing communities of practice. Journal of Knowledge Management, v. 7, n. 1, 2003.

ARORA, E. Knowledge Management in public sector. International Refereed Research Journal, v. 2, n. 1, jan., 2011.

ASIAN PRODUCTIVITY ORGANIZATION (APO). Knowledge management for the public sector. Japão: APO, 2013. 85 p.

BACELLAR, R. P. Juizados Especiais: a nova mediação paraprocessual. São Paulo: Revista dos Tribunais, 2004.

BALBONI, M. R. et al. Indicadores para la sociedad de la información en América Latina y el Caribe: avances y desafíos en la medición del acceso y uso de las tecnologías de información y comunicación. In: CONGRESO INTERNACIONAL DEL CLAD SOBRE LA REFORMA DEL ESTADO Y DE LA ADMINISTRACIÓN PÚBLICA, 14., 2009. Anais... Salvador: CLAD, 2009. 
BARNEY, J. Firm resources and sustained competitive advantage. Journal of Management, v. 17, n. 1, mar.1991.

BARROS, A. J. P.; LEHFELD, N. A. S. Projeto de pesquisa: propostas metodológicas. Petrópolis, RJ: Vozes, 1990.

BARTOL, K.; SRIVASTAVA, A. Encouraging knowledge sharing: the role of organizational reward systems. Journal of Leadership \& Organizational Studies, v. 9, n. 1, p. 64-76, 2002.

BATES, M. J. The invisible substrate of Information Science. Journal of the American Society for Information Science, v. 50, n. 12, p. 1043-1050, 1999.

BATISTA, F. F. Modelo de gestão do conhecimento para a administração pública brasileira: como implementar a gestão do conhecimento para produzir resultados em benefício do cidadão. Brasília: IPEA, 2012.

BAYER, F. M. Modelagem e inferência em regressão beta. 2011. Tese (Doutorado)Universidade Federal de Pernambuco, Recife, 2011. Disponível em:

<https://www.ufpe.br/ppge/images/teses/tese004.pdf>. Acesso em: 25 jan. 2016.

BECERRA, M; LUNNAN, R; HUEMER, L. Trustworthness, risk and transfer of tacit and explicit knowledge between alliance parteners. Journal of Management Studies, v. 45, n. 4, jun., 2008.

BENJAMIN Franklin. [S.1.]: Wikiquote, 2014. Disponível em: <https://pt.wikiquote.org/ wiki/Benjamin_Franklin>. Acesso em: fev. 2016.

BIOGRAFIA de Paulo de Tarso. 2016. Disponível em: <http://pensador.uol.com.br/autor/ paulo de tarso/biografia/>. Acesso em: mar. 2016.

BIERLY, P. E.; KESSLER, E. H.; CHRISTENSEN, E. W. Organizational learning, knowledge and wisdom. Journal of Organizational Change Management, v. 13, n. 6, p. 595-618, 2000.

BONACHE, J. El valor estratégico de la movilidad global de puestos, personas y conocimientos em las multinacionales. Universia Business Review, Tercer trimestre 2010.

BORGATTI, S. P.; LI, X. On social network analysis in a supply chain context. Journal of Supply Chain Management, Spring, 2009.

BRASIL. Conselho da Justiça Federal (CJF). Centro de Estudos Judiciários, Secretaria de Pesquisa e Documentação. Juizados Especiais Federais. Brasília: CJF, 2000. (Série Pesquisas do CEJ; 7).

BRASIL. Conselho da Justiça Federal (CJF). Centro de Estudos Judiciários, Secretaria de Pesquisa e Documentação. Diagnóstico da estrutura e funcionamento dos Juizados Especiais Federais. Brasília: CJF, 2003. (Série Pesquisas do CEJ; 12).

BRASIL. Conselho Nacional de Justiça. O que é e o que faz a Justiça Estadual?. 2015c. Disponível em: <http://www.cnj.jus.br/noticias/cnj/79204-o-que-e-e-o-que-faz-a-justicaestadual >. Acesso em: 20 fev. 2016.

BRASIL. Conselho Nacional de Justiça. Resolução N. ${ }^{\text {76, de }} 12$ de maio de 2009. Dispõe sobre os princípios do Sistema de Estatística do Poder Judiciário, estabelece seus indicadores, 
fixa prazos, determina penalidades e dá outras providências. DOU, 10 jun. 2009. Disponível em: 〈http://www.cnj.jus.br/atos-normativos?documento=110f > . Acesso em: abr. 2016.

BRASIL. Conselho Nacional de Justiça. Justiça em números 2012: ano-base 2011. Brasília: CNJ, 2012.

BRASIL. Conselho Nacional de Justiça. Justiça em números 2013: ano-base 2012. Brasília: CNJ, 2013.

BRASIL. Conselho Nacional de Justiça. Justiça em números 2014: ano-base 2013. Brasília: CNJ, 2014a.

BRASIL. Conselho Nacional de Justiça. Justiça em números 2015: ano-base 2014. Brasília: CNJ, 2015.

BRASIL. Conselho Nacional de Justiça. Diretriz Estratégica 2016. Brasília: CNJ, 2016.

Disponível em: <http://www.cnj.jus.br/files/conteudo/arquivo/2016/03/

4636da73c3910c7f86cde8cd19226b42.pdf. Acesso em 01.04.2016.

BRASIL. Constituição (1988). DOU, Brasília, 5 out. 1988. Disponível em:

<http://www.planalto.gov.br/ccivil_03/constituicao/constituicaocompilado.htm>. Acesso em: 08 ago. 2012.

BRASIL. Emenda Constitucional no 22, de 18 de março de 1999. Acrescenta parágrafo único ao art. 98 e altera as alíneas "i" do inciso I do art. 102 e "c" do inciso I do art. 105 da Constituição Federal. DOU, 19 mar. 1999. Disponível em: <http://www.planalto.gov.br/ ccivil_03/Constituicao/Emendas/Emc/emc22.htm>. Acesso em: 11.02.2014.

BRASIL. Emenda Constitucional $\mathrm{n}^{\mathbf{0}}$ 45, de 30 de dezembro de 2004. Altera dispositivos dos arts. 5' , 36, 52, 92, 93, 95, 98, 99, 102, 103, 104, 105, 107, 109, 111, 112, 114, 115, 125, 126, 127, 128, 129, 134 e 168 da Constituição Federal, e acrescenta os arts. 103-A, 103B, 111-A e 130-A, e dá outras providências. DOU, 31 dez. 2004. Disponível em:

$<$ http://www.planalto.gov.br/ ccivil_03/Constituicao/Emendas/Emc/emc22.htm>. Acesso em:15.05.2014.

BRASIL. Lei ${ }^{\circ} 10.259$, de 12 de julho de 2001. Dispõe sobre a instituição dos Juizados Especiais Cíveis e Criminais no âmbito da Justiça Federal. DOU, 13 jul. .2001. Disponível em: <http://www.planalto.gov.br/ccivil_03/leis/LEIS_2001/L10259.htm>. Acesso em: 19 mar. 2013.

BRASIL. Lei n ${ }^{\circ}$ 9.099, de 26 de setembro de 1995. Dispõe sobre os Juizados Especiais Cíveis e Criminais. DOU, 27 set. 1995. Disponível em:

<http://www.planalto.gov.br/ccivil_03/leis/19099.htm>. Acesso em: 19 mar. 2013.

BRASIL. Tribunal Regional Federal $1^{a}$ Região (TRF1). Olhares do JEF, Coordenação dos Juizados Especiais Federais. Brasília: TRF1, 2014 b.

BRASIL. Tribunal Regional Federal (Região, 5) (TRF5). Ritos dos Juizados. 2015. Disponível em: <http://jef.trf5.jus.br/orientacaoCidadao/ritoJuizados.php>. Acesso em: 18 nov. 2015.

BRASIL. Tribunal Superior do Trabalho. Sobre a justiça do trabalho. 2015a. Disponível em: <http://www.tst.jus.br/web/acesso-a-informacao/justica-do-trabalho>. Acesso em: jan. 2016.

BRASIL. Tribunal Superior Eleitoral. Justiça Eleitoral. 2015b. Disponível em: $<$ http://www.justicaeleitoral.jus.br/>. Acesso em: jan. 2016. Acesso em: 20 fev. 2016. 
BROHM, R.; HUYSMAN, M. The utopia of communities: an ethnographic account of the rise and fall of business communities. In: INTERNATIONAL CONFERENCE, 5., 2003. Anais... [S.1.]: Lancaster University, 2003. Disponível em: 〈http://www2.warwick.ac.uk/fac/soc/wbs/ conf/olkc/archive/olk5/papers/paper5.pdf $>$. Acesso em: abr. 2016.

BUBER, M. Do diálogo ao dialógico. São Paulo: Perspectiva, 1982.

CALAMANDREI, P. Eles, os juízes, vistos por um advogado. São Paulo: Martins Fontes, 1995.

CARVALHO, A. R. S.; MASCARENHAS, C. C.; OLIVEIRA, E. A. A. Q. Ferramentas de disseminação do conhecimento em uma instituição de C, T \& I de defesa nacional. Revista de Gestão da Tecnologia e Sistemas de Informação, v. 3, n. 2, p. 77-92, 2006.

CASSELMAN, R. M.; SAMSON, D. Internal, collaborative and competitive knowledge capability. In: SYSTEM SCIENCES (HICSS), HAWAII INTERNATIONAL

CONFERENCE, 44., 2011. Anais... Kauai: HICSS, 2011.

CENTRO DE REFERÊNCIA EM INTELIGÊNCIA EMPRESARIAL (CRIE). Instituto Alberto Luiz Coimbra de Pós-Graduação e Pesquisa de Engenharia (COPPE). Universidade Federal do Rio de Janeiro (UFRJ). 2015. Disponível em $<$ http://portal.crie.coppe.ufrj.br/portal/main.asp?ViewID=\{B796852D-22A7-4515-997F537BD8378B1C $\} \& u=u>$. Acesso em: 22 dez. 2015.

CHANIN, R. et al. Avaliação Quantitativa de Sistemas. Porto Alegre: Pontifícia Universidade Católica do Rio Grande do Sul, 2005. Disponível em <http://www.inf.pucrs.br/ paulof/ads/AQS-tudo.pdf>. Acesso em: 22 fev. 2016.

CHESHER, C.; HOWARD, S. Balancing Knowledge Management and Knowledge Mobility in the Connected University. In: FENWICK, Tara; FARRELL, Lesley (Ed.). Knowledge mobilization and educational research politics, languages and responsabilities. [S. 1.]: Routledge, 2011.

CHOO, C. W. A organização do conhecimento: como as organizações usam a informação para criar significado, construir conhecimento e tomar decisões. 3 ed. São Paulo: Editora Senac, 2003.

CHRISTENSEN, P.H. Knowledge Sharing: Moving Away from the Obsession with Best Practice. Journal of Knowledge Management, v. 11, n. 1, p. 36 - 47, 2007.

COLLINS, W. Cobuild English Dictionary. London: HarperCollins Publishers, 1998.

CONGRESSO NACIONAL DOS JUIZADOS ESPECIAIS FEDERAIS, 1., 2003, Brasília. Relatório... Brasília: CJF, 2003.

CORREDOIRA, R.; ROSENKOPF, L. Should auld acquaintance be forgot? the reverse transfer of knowledge through mobility ties. Strategic Management Journal, v. 31, p. 159$181,2010$.

COUTINHO, P. L. A. et al. Construindo um sistema de gestão da inovação tecnológica: atividades, estrutura e métricas. Revista ADM.MADE, v. 12, n. 3, p.19-49, set./dez., 2008.

CROSS, J. Informal learning. São Francisco: Pfeiffer, 2007. 
CUNHA, Luciana G. et al. Relatório ICJBrasil: $4^{\text {o }}$ Trimestre / 2010. [S.1.]: FGV, 2010. Disponível em: <http://bibliotecadigital.fgv.br/dspace/bitstream/handle/10438/7837/ RelICJBrasil4TRI2010\%27.pdf?sequence=1>. Acesso em: 14 dez. 2012.

CUNHA, M. B. da. Dicionário de biblioteconomia e arquivologia. Brasília: Briquet de Lemos, 2008.

DAVENPORT, T.; PRUSAK, L. Conhecimento empresarial. Rio de Janeiro: Campus, 1999.

DECAROLIS; D. M.; DEEDS, D. L. The impact of stocks and flows of organizational knowledge on firm performance: an empirical investigation of the biotechnology industry. Strategic Management Journal, Strat. Mgmt. J., 20: 953-968 (1999).

DESCARTES, R. Discurso sobre o método. 2. ed. Bauru: EDIPRO, 2006.

DYER, J. H.; NOBEOKA, K. Creating and managing a high performance knowledge-sharing network: the Toyota case. 1998. Disponível em: <http://dspace.mit.edu/bitstream/handle/1721.1/1441/147b.pdf $>$. Acesso em: 21 jul. 2015.

EDVINSSON, L.; MALONE, M. S. El capital intelectual: cómo identificar y calcular el valor de los recursos intangibles de su empresa. Barcelona: Ediciones Gestión 2000 S. A., 1999.

FANG, Y. et al. Research notes and commentaries. International diversification, subsidiary performance, and the mobility of knowledge resources. Strategic Management Journal, v. 28, n. 1053, 2007.

FERRAROTTI, F. Sobre a autonomia do método biográfico. Sociologia - Problemas e práticas, n. 9, p. 171-177, 1991.

FERREIRA, A. B. de H. Dicionário Aurélio da língua portuguesa. 5. ed. Curitiba: Positivo, 2010.

FERRETTI, J. R. P. Qualidade em ambiente de burocracia: o caso da Justiça Federal do Estado do Amazonas. 2001. Disponível em:

$<$ http://bibliotecadigital.fgv.br/dspace/bitstream/handle/10438/4003/Ferreti.PDF?sequence=1

$>$. Acesso em: 13 ago. 2013.

FERRETTI, J. R. P. Carta ao Senhor Secretário de Reforma do Poder Judiciário do Ministério da Justiça. Circulus Revista da Justiça Federal do Amazonas, v. 2, n. 4, p. 137-140, 2004.

FETTERHOFF, T.; NILA, P.; MCNAMEE, R. C. Accessing internal knowledge: organizational practices that facilitate the transfer of tacit knowledge. Research Technology Management, p. 50-54, nov./dez. 2011.

FLEURY, M.T.; OLIVEIRA JR., M.M. (Org.) Gestão estratégica do conhecimento: integrando aprendizagem, conhecimento e competências. São Paulo: Atlas, 2001.

FONSECA, B. T. V. Modernização da Gestão Judiciária. 2009. 46 f. Monografia (Especialização)- FACE, UnB, Brasília, 2009. Disponível em: <http://bdm.bce.unb.br/bitstream/10483/1540/1/2009_BardiaTupyVieiraFonseca.pdf>. Acesso em: 30 mar. 2012.

FONSECA, Hugo S. P. Breves considerações sobre a RPV (Requisição de Pequeno Valor). 2008. Disponível em: 
<http://www.rkladvocacia.com/arquivos/artigos/art_srt_arquivo20080731142915.pdf>. Acesso em:

FRESNEDA, P. S. V.; GONÇALVES, S. M. G. A experiência brasileira na formulação de uma proposta de política de gestão do conhecimento para a administração pública federal. Brasília: Câmara dos Deputados, Coordenação de Publicações, 2007. 83 p.

GARVIN, D. et al. Aprender a aprender. HSM Management, v. 9, p. 58-65, jul./ago. 1998.

GASSMANN, O. Opening up the innovation process: towards an agenda. R \& D Management, v. 36, n. 3, 2006.

GIBRAN, K. O profeta. Porto Alegre: L\&PM, 2002.

GIL, A. C. Como elaborar projetos de pesquisa. 5. ed. São Paulo: Atlas, 2010.

GIRARD, J. P.; MCINTYRE, S. Knowledge management modeling in public sector organizations: a case study. International Journal of Public Sector Management, v. 23, n. 1, p. 71-77, 2010.

GODFREY, L; FUNKE, N; MBIZVO, C. Bridging the science-policy interface: a new era for South African research and the role of knowledge brokering. S. Afr. J. sci., v. 106, n.5-6, May./Jun. 2010.

$\mathrm{GOH}, \mathrm{S}$. C. Managing effective knowledge transfer: an integrative framework and some practice implications. Journal of Knowledge Management, v. 6, n. 1, p. 23-30, 2002.

GOLDENBERG, M. A arte de pesquisar: como fazer pesquisa qualitativa em Ciências Sociais. 9. ed. Rio de Janeiro: Record, 2005.

GOMES, M. V. D. A Gestão do Conhecimento na Administração Pública: paradigma para o Judiciário fluminense. 2005. 54 f. Monografia (Especialização)-Fundação Getúlio Vargas, 2005. Disponível em: <http://www.tjrj.jus.br/c/document_library/get_file? uuid=61cb13158247-454f-87b1-b04feba55775>. Acesso em: 23 maio 2013.

GONDIM, L. M. P; LIMA, J. C. A pesquisa como artesanato intelectual: considerações sobre método e bom senso. São Carlos: EdUFSCar, 2010.

GRANGEIA, M. A. D. A crise de gestão do Poder judiciário: o problema, as consequências e os possíveis caminhos para a solução. 2011. Disponível em:

<http://www.enfam.jus.br/portal stj/publicacao/download.wsp?tmp.arquivo=2099 >. Acesso em: 06 ago. 2012.

GRANT, R. M. The resource-based theory of competitive advantage: implication for strategy formulation. In: ZACK M. H. Knowledge and strategy. New York: Routledge, 2011.

GRANT, R. M. Toward a knowledge-based theory of the firm. Strategic Management Journal, v. 17, p. 109-122, 1996.

GRATTON, L.; GHOSHAL, S. Improving the quality of conversations. Organizational Dynamics, v. 31, n. 3, p. 209-223, 2002.

GRESSLER, L. A. Introdução à pesquisa: projetos e relatórios. São Paulo-SP: Edições Loyola, 2003.

GROTTO, D. Um olhar sobre a Gestão do Conhecimento. Revista de Ciências da

Administração, v. 3, n. 6, set. 2001. 
GUIA DE DIREITOS. Justiça Militar. 2015. Disponível em:

$<$ http://www.guiadedireitos.org/index.php?option=com_content $\&$ view=article \&id=825\&Item $\mathrm{id}=153>$. Acesso em: 20 fev. 2016.

HAIR, J. F. Jr.; BLACK, W. C.; BABIN, B. J.; ANDERSON, R. E.; TATHAM, R. L. Análise Multivariada de Dados. 6. ed. Porto Alegre: Bookman, 2009.

HEISIG, P. Harmonisation of knowledge management: comparing $160 \mathrm{KM}$ frameworks around the globe. Journal of Knowledge Management, v. 13, n. 4, p. 4-31, 2009.

HENRY Thoreau. [S.1.]: Wikiquote, 2014. Disponível em: <https://pt.wikiquote.org/ wiki/Henry_Thoreau>. Acesso em: fev. 2016.

HSU, I-Chieh. Knowledge sharing practices as a facilitating factor for improving organizational performance through human capital: a preliminary test. Expert Systems with Applications, v. 35, n.3, p. 1316-1326, 2008.

HUANG, X. OOSTERLEE, C. W. Generalized beta regression models for random loss given default. The Journal of Credit Risk, v. 7, p. 45-70, 2011.

INKPEN, A. C. Creating knowledge through collaboration. California Management Reviews, v. 39, n. 1, 1996.

INSTITUTO DE PESQUISA ECONÔMICA APLICADA (IPEA). Acesso à Justiça Federal: dez anos de juizados especiais. Brasília: CJF, CEJ, 2012. (Série pesquisas do CEJ; 14).

INSTITUTO DE PESQUISA ECONÔMICA APLICADA (IPEA). Gestão do conhecimento na administração pública: resultados da pesquisa IPEA 2014 - práticas de gestão do conhecimento. Brasília: IPEA, 2015. (Série Texto para Discussão; 2120).

ITAMI, H. Mobilizing invisible assets. Cambridge: Harvard University Press, 1987.

ISAAC Newton. [S.1.]: Wikiquote, 2014. Disponível em: <https://pt.wikiquote.org/ wiki/Isaac Newton>. Acesso em: fev. 2016.

JELENIC, D. The importance of knowledge management in organizations - with emphasis on the balanced scorecard learning and growth perspective. 2011. Disponível em:

<http://issbs.si/press/ISBN/978-961-92486-3-8/papers/ML11-1.pdf>. Acesso em: mar. 2016.

JOBIM, Nelson. Judiciário: construindo um novo modelo. In: FUNDAÇÃO GETULIO VARGAS. A reforma do Poder Judiciário no estado do Rio de Janeiro. Rio de Janeiro: FGV, 2005.

JOLLIFFE, I.T. Principal Component Analysis. 2.ed. New York: Springer Series in Statistics, 2002.

K4HEALTH. About K4Health. 2015. Disponível em: <http://www.k4health.org/aboutk4health>. Acesso em: 20 ago. 2013.

KALDEWEY, D. Tacit knowledge in a differentiated society. In: ADLOFF, F.; GERUND, K.; KALDEWEY, D. Revealing tacit knowledge: embodiment and explication. Bielefeld: Transcript, 2015.

KEGLOVITS, B. T. Sharing Tacit Knowledge in an Organization. 2013. Tese (Doutorado)Haaga-Helia, University of Applied Sciences, Karlsruhe, 2013. Disponível em:

<https://www.theseus.fi/handle/10024/59991>. Acesso em: 28 mar. 2014. 
KERCKHOVE, D. de. The Information Management Round Table: Connected Intelligence. [S.1.]: [s.n.], 1999. Disponível em: <http://dspace.cigilibrary.org/jspui/ bitstream/123456789/11309/1/Connected\%20Intelligence.pdf?1>. Acesso em: 14 maio 2013.

KERLINGER, F. N. Metodologia da pesquisa em Ciências Sociais: um tratamento conceitual. São Paulo: Editora Pedagógica e Universitária (EPU), 2003.

KNOCKAERT, M. et al. The relationship between knowledge transfer, top management team composition, and performance: the case of Science-Based Entrepreneurial Firms.

Entrepreneurship Theory and Practice, v. 35, n. 4, p. 777-803, 2011.

KOGUT, B; ZANDER, U. Knowledge of the firm and the evolutionary theory of the multinational corporation. Journal of International Business Studies, v. 24, n. 4, 1993.

KORHONEN, M. Tacit knowledge and weak signals in organizational learning: managing knowledge to create sustainable competitive advantage case company ltd. 2014. Mestre (Mestrado em Administração de Empresas)- Turku University of Applied Sciences, Programme in Business Administration, International Business Management, Finland, 2014.

KRISHNAVENI, R.; SUJATHA, R. Communities of practice: an influencing factor for effective knowledge transfer in organizations. The IUP Journal of Knowledge Management, v. 10, n. 1, 2012.

LAHTI, S; MOILANEN, R. Sharing of the tacit knowledge - a challenge of managing young and aging employees. 2004. Disponível em:

<http://www.ouderenenarbeid.be/Documenten/EIASM_tacit_knowledge.pdf >. Acesso em: 16 jan. 2016.

LALANDE, A. Vocabulário técnico e crítico da Filosofia. 3. ed. São Paulo: Martins Fontes, 1999.

LASTRES, M. M.; ALBAGLI, S. Informação e globalização na era do conhecimento. Rio de Janeiro: Campus, 1999.

LAVILLE, C. A construção do saber: manual da metodologia da pesquisa em ciências humanas. Porto Alegre: Artmed, 1999.

LEITE, F. C. L. O conhecimento científico tácito na dinâmica da pesquisa: alguns indícios. DataGramaZero: Revista de Ciência da Informação, v. 8, n. 3, jun. 2007.

LEMOS, B; JOIA, L. A. Fatores relevantes à transferência de conhecimento tácito em organizações: um estudo exploratório. Gest. Prod., São Carlos, v. 19, n. 2, p. 233-246, 2012.

LEMOS, C. Inovação na era do conhecimento. Parcerias Estratégicas, v. 8, p. 157-179, maio 2000 .

LEONARD, D.; SENSIPER, S. The role of tacit knowledge in group innovation. California Management Review, v. 40, n. 3, Spring 1998.

LINDE, K. V. Desvendando a Gestão do Conhecimento. Entrevistador: Marco Pace.

Intermanagers, set. 2000. Disponível em: 〈http://migre.me/t8FVw〉. Acesso em: 19 nov. 2015 .

LIU, C. L. E. Knowledge mobility in cross-border buyer-supplier relationships. Manag Int Rev, n. 52, p. 275-291, 2012. 
LOENHOFF, J. Tacit knowledge: shared and embodied. In: ADLOFF, F.; GERUND, K.; KALDEWEY, D. Revealing tacit knowledge: embodiment and explication. Bielefeld: Transcript, 2015.

LONGANEZI, T.; COUTINHO, P.; BOMTEMPO, J. V. M. Um modelo referencial para a prática da inovação. Journal of Technology Management \& Innovation, v. 3, n. 1, 2008.

LOPES, J. D. O juiz como gestor: gestão de pessoas. In: CURSO DE FORMAÇÃO PARA INGRESSO NA CARREIRA DA MAGISTRATURA, 1., 2009. Anais... [S.1]: Escola Judicial Desembargador Edésio Fernandes, 2009. Disponível em: <http://bd.tjmg.jus.br/ jspui/bitstream/tjmg/681/1/palLJ-OJU.pdf> . Acesso em: 17/11/2015.

LOUREIRO, J. M. M. Socialização da informação: nadando contra a corrente. Informação \& Sociedade: Estudos, v.12, n.2, 2002.

LYTRAS, M. D. POULOUDI, A. Towards the development of a novel taxonomy of knowledge management systems from a learning perspective: an integrated approach to learning and knowledge infrastructures. Journal of Knowledge Management, v. 10, v. 6, p. 64-80, 2006.

MAIA, V. L. da H. A gestão do conhecimento integrada nos processos empresariais. 2001. Dissertação (Mestrado) - Instituto Superior de Contabilidade e Administração do Porto, 2001. Disponível em: <http://recipp.ipp.pt/bitstream/10400.22/377/1/

Vera_Maia_MAA_2011.pdff>. Acesso em: 13 maio 2013.

MARCONI, M. A.; LAKATOS, E. M. Fundamentos de metodologia científica. 7. ed. São Paulo: Atlas, 2010.

MARSICK, V. J. Toward a unifying framework to support informal learning theory, research and practice. Journal of Workplace Learning, v. 21, n. 4, 2009.

MARTINS, L. M. P.; LIMA, M. F.; PESSANHA, V. L. R. Gestão do conhecimento como instrumento de modernização do Poder Judiciário Fluminense. 2005. Monografia (Especialista em Gestão do Conhecimento e Inteligência Empresarial) - Programa de Pósgraduação em Engenharia, Universidade Federal do Rio de Janeiro, Rio de Janeiro, 2005. Disponível em: <http://www.tjrj.jus.br/institucional/dir_gerais/ dgcon/pdf/monografia/servidor/2005/leila marcelo vera monografia.pdf $>$. Acesso em: 21 dez. 2015.

MCDERMOTT, R. Why information technology inspired but cannot deliver knowledge management. In: LESSER, E. L.; FONTAINE, M. A.; SLUSHER, J. A. Knowledge and Communities. New York: Routledge, 2000. Disponível em: <http://migre.me/t8Gje>. Acesso em: 11.08.2013.

MCINERNEY, C. R. Compartilhamento e gestão do conhecimento: profissionais da informação e um ambiente de confiança mútua. In: TARAPANOFF, K (org.). Inteligência, informação e conhecimento em corporações. Brasília: IBICT, UNESCO, 2006.

METS, T. Creative Business Model Innovation for Globalizing SMEs. In: BURGERHELMCHEN, Thierry (Ed.). Entrepreneurship: Creativity and Innovative Business Models. Shanghai: Intech. [S.1]: [s.n.], 2012. p. 169-190. Disponível em: $<$ http://www.intechopen.com/books/entrepreneurship-creativity-and-innovative-businessmodels/creative-business-model-innovation-for-globalizing-smes >. Acesso em: 06 jul. 2013. 
MIRANDA, A; SIMEÃO, E. Información, Cultura y Sociedad, Buenos Aires, n.10, p.2740, 2004.

MIRANDA, M. M. S; MORESI, E. A. D. A gestão do conhecimento no compartilhamento de melhores práticas em uma base de dados no Tribunal Regional Federal da Primeira Região. JISTEM Revista de Gestão da Tecnologia e Sistemas de Informação, v. 7, n. 2, p. 409432, 2010.

MOREIRA NETO, D. F. O sistema judiciário brasileiro e a reforma do estado. São Paulo: Celso Bastos Editor, 1999.

MORESI, E. Metodologia da pesquisa. Brasília: Universidade Católica de Brasília (UCB), 2004.

MOTTA, P. R. Revisitando a controvérsia sobre a transmissibilidade intercultural do conhecimento administrativo. Cad. EBAPE.BR, Rio de Janeiro, v.12 n.3, July/Sept. 2014.

NALINI, J. R. A rebelião da toga. Campinas: Millennium, 2008.

NGAH, R.; JUSOFF, K. Tacit Knowledge Sharing and SMEs' Organizational Performance. International Journal of Economics and Finance, v. 1, n. 1, Feb. 2009.

NISSEN, M.; LEVITT, R. Dynamic models of knowledge-flow dynamics. Stanford: CIFE, 2002.

NONAKA, I. A dynamic theory of organizational knowledge creation. Organization Science, v. 5, n. 1, Feb. 1994.

NONAKA, I. KONNO, N. The concept of "Ba": building a foundation for knowledge creation. California Management Review, v. 40, n. 3, 1998.

NONAKA, I; TAKEUCHI, H. Criação de conhecimento na empresa. Rio de Janeiro: Elsevier, 1997.

NONAKA, I; TOYAMA, R. The knowledge-creating theory revisited: knowledge creation as a synthesizing process. Knowledge Management Research \& Practice, v. 1, p. 2-10. 2003.

OLIVEIRA, L. P. Gestão do Conhecimento na Universidade Corporativa Banco do Brasil. Dissertação (mestrado) - Universidade de Brasília, Faculdade de Ciência da Informação, Programa de Pós-Graduação em Ciência da Informação, 2014.

OLIVEIRA, V. P. de. O conhecimento tácito na transferência de conhecimento científico: Mr. Data aprende a dançar. Textos para Discussão, n. 31, Campinas, SP: DPCT/IG/Unicamp, 2000.

OLIVEIRA, V. P. Uma informação tácita. DataGramaZero: Revista de Ciência da Informação, v. 6, n. 3, jun. 2005.

OLIVEIRA, W. B. O papel social do juiz. Revista Online IBRAJUS, 2009. Disponível em: 〈http://www.ibrajus.org.br/revista/artigo.asp?idArtigo=148>. Acesso em: mar. 2016.

PARANÁ. Tribunal de Justiça do Estado do Paraná. Portaria no 4.962-D.M/2012. DJPR, 10 dez. 2012. Disponível em: <http://www.jusbrasil.com.br/diarios/44104239/djpr-10-12-2012pg-164>. Acesso em: 30 abr. 2013.

PARRA FILHO, D. Metodologia Científica. São Paulo: Futura, 1998. 
PATOKORPI, E. Low knowledge in cyberspace: abduction, tacit knowledge, aura and the mobility of knowledge. Human Systems Management, n. 25, p. 211-220, 2006.

PENROSE, E. A teoria do crescimento da firma. Campinas: Editora da Unicamp, 2006.

PETERS, T. Prosperando no caos. São Paulo: Editora Harbra, 1989.

PETERAF, M. A. The cornerstones of competitive advantage: a resource-based view.

Strategic Management Journal, v. 14, p. 179-191, 1993.

PINHEIRO, A. C. Judiciário, reforma e economia: a visão dos magistrados. São Paulo:

Febraban, 2002. Disponível em: <http://www.febraban.org.br/arquivo/destaques/ armando_castelar_pinheiro2.pdf>. Acesso em: 22 abr. 2013.

PIRES, Vladimir S. Cultura organizacional e memória empresarial na indústria da moda: gestão de ativos do conhecimento como estratégia corporativa para a construção de identidades de marcas. E-COM, Belo Horizonte, v. 5, p. 1-15, 2012.

POLANYI, M. The tacit dimension. Chicago: University of Chicago Press, 2009.

POPPER, K. Conhecimento objetivo: uma abordagem evolucionária. Belo Horizonte: Ed. Itatiaia, 1999.

PORT, O. H. M. Sua excelência, o gestor. Revista Justiça e Educação, v. 1, n. 1, jul./dez. 2012.

PORTER, M. E. Vantagem competitiva: criando e sustentando um desempenho superior. Rio de Janeiro: Campus, 1989.

PORTER, M. E. Competitive Strategy. New York: Free Press, 1980.

PRIBERAM. Dicionário Eletrônico Priberam da Língua Portuguesa. 2010. Disponível em: 〈http://www.priberam.pt/dlpo/dlpo.aspx?pal=metodologia >. Acesso em: 15 abr. 2013.

QUÉRÉ, M. On the importance of innovation policy in Europe: A micro-macro discussion about the transition towards a knowledge-based society. 2003. Disponível em:

<http://migre.me/t8Hko >. Acesso em: 20 set. 2013.

RAZOUK, A. A.; BAYAD, M.; WANNENMACHER, D. Strategic human resource management and tacit knowledge transfer: a case study. Human Systems Management, n. 28, p. 77-82, 2009.

REIS, M. L. Processos de inovação e políticas de ciência e tecnologia: um olhar sobre a função social da escola brasileira na contemporaneidade. Sociologias, Porto Alegre, ano 3, n. 6, p. 52-69, jul./dez., 2001.

REIS, N. V. da S. A lerdeza da Justiça. Circulus Revista da Justiça Federal do Amazonas, v. 1, n. 1, p. 30-32, 2003.

REZENDE, Y. Informação para negócios: os novos agentes do conhecimento e a gestão do capital intelectual. Ci. Inf., Brasília, v. 31, n. 2, p. 120-128, maio/ago., 2002.

RUDIO, F. V. Introdução ao projeto de pesquisa científica. Petrópolis: Vozes, 1986.

RUSCHEL, A. J. Modelo de conhecimento para apoio ao juiz na fase processual trabalhista. 2012. 206 f. Tese (Doutorado)- Universidade Federal de Santa Catarina, 
Florianópolis, 2012. Disponível em: <http://btd.egc.ufsc.br/wpcontent/uploads/2012/ 08/AirtonJoseRuschel2012_206pg1.pdf>. Acesso em: 16 nov. 2012.

SADEK, M. T. Judiciário: mudanças e reformas. Estudos Avançados, São Paulo, v. 18, n. 51, ago. 2004.

SAINT-ONGE, H. Tacit knowledge: the key to the strategic alignment of intellectual capital. In: ZACK, M. H. (Org.). Knowledge and strategy. New York: Routledge, 2011, 223-230.

SANTOS, C. M. D.; CASTILHO, I. V.; KILIMNIK, Z. M. O Juiz de Direito como gestor: competências necessárias para uma difícil conciliação de papéis. Revista Gestão \& Tecnologia, v. 6, n. 2, p. 1-15, 2006.

SELEM, L. C. A. Gestão judiciária estratégica: o Judiciário em busca da eficiência. Natal: Escola da Magistratura do Estado do Rio Grande do Norte (Esmarn), 2004.

SELLTIZ, C.; WRIGHTSMAN, L. S.; COOK S. W. Métodos de Pesquisa nas Relações Sociais. 2. ed. São Paulo: EPU, 1987.

SEMINÁRIO ATUALIDADE E FUTURO DA ADMINISTRAÇÃO DA JUSTIÇA, 2013, Porto Alegre. Anais... Porto Alegre: TRF4, 2013

SEMINÁRIO JUSTIÇA EM NÚMEROS, 5., 2012, Brasília. Anais... Brasília: CNJ, 2012.

SEMINÁRIO JUIZADOS ESPECIAIS: DIAGNÓSTICOS E PERSPECTIVAS, 2013, Brasília. Anais... Brasília: CNJ, 2013.

SENGE, P. Fifth discipline. The art and practice of the learning organization. New York: Doubleday, 2006.

SERPELL, A. Administración de operaciones de construcion. Santiago: Universidad Catolica, 1993.

SHOUKAT, A. Investigating the correlation between knowledge asset management and organizational performance. In: INTERNATIONAL CONFERENCE ON BUSINESS AND ECONOMIC RESEARCH, 3., 2012. Proceeding... Bandung: ICBER, 2012.

SIFUENTES, M. Inovações na administração e funcionamento da Justiça Federal: um novo juiz para um novo Poder. Revista CEJ, Brasília, n. 33, p. 62-71, abr./jun., 2006.

SILVA JÚNIOR, W. N. da. Apresentação. In: FÓRUM DOS JUIZADOS ESPECIAIS FEDERAIS, 4., 2008. Enunciados... Brasília; CJF; AJUFE, 2008.

SILVA, D. P. Vocabulário jurídico. 27. ed. Rio de Janeiro: Companhia Editora Forense, 2008.

SILVA, J. L. O jus postulandi nos juizados especiais federais: a mitigação do princípio da igualdade nas ações previdenciárias. In: SEMANA JURÍDICA, 3., 2010. Anais... São Paulo: USP, 2010. Disponível em: 〈http://www.direitorp.usp.br/arquivos/noticias/

sites eventos/3 semana juridica 2010/papers/Julia\%20Lenzi\%20Silva.pdf >. Acesso em: 18 nov. 2015.

SILVA, E. H.; VON S. C. DA. A comunidade de prática virtual como ferramenta da gestão do conhecimento: uma proposta para o Tribunal de Justiça de Pernambuco.

Dissertação (Mestrado)- Universidade Federal de Pernambuco, Recife, 2004. 
SILVA, S. L. Gestão do conhecimento: uma revisão crítica orientada pela abordagem da criação do conhecimento. Ci. Inf., Brasília, v. 33, n. 2, p. 143-151, maio/ago. 2004.

SILVEIRA, F. R. A morosidade no poder judiciário e seus reflexos econômicos. Porto Alegre: Sergio Antonio Fabris, 2007.

SMITH, E. A. The role of tacit and explicit knowledge in the workplace. Journal of Knowledge Management, v. 5, n. 4, p. 311-321, 2001.

SMITH, H. A.; MCKEEN, J. D.; SINGH, S. Tacit knowledge: making it happen. Journal of Information Science and Technology, v. 4, n. 2, 2007.

SOUSA, A. Coeficiente de Correlação Linear de Pearson. 2016. Disponível em:

<http://www.aurea.uac.pt/pdf MBA/coef correl Pearson.pdf $>$. Acesso em: 23 jan. 2016.

SOUZA, A. C. O perfil do juiz gestor: o intercâmbio interdisciplinar como critério catalisador de uma boa gestão. Revista Justiça e Educação, v. 1, n. 1, jul./dez. 2012.

STAPLETON, L.; SMITH, D.; MURPHY, F. Systems engineering methodologies, tacit knowledge and communities of practice. AI \& Soc, n. 19, p. 159-180, 2005.

STEFANOVITZ, J. P. Criação de conhecimento e inovação na indústria de alta tecnologia: estudo e análise de casos em uma empresa do setor de automação industrial. 2006. Dissertação (Mestrado) - Escola de Engenharia de São Carlos, Universidade de São Paulo (USP), São Carlos, 2006.

SVEIBY, K. E. The new organizational wealth: managing and measuring knowledge-based assets. San Francisco: Berrett-Koehler Publishers Inc., 1997.

SZULANSKI, G. Exploring internal stickiness: impediments to the transfer of best practice within the firm. Strategic Management Journal, v. 17, p. 27-43, 1996.

SZULANSKI, G. Sticky knowledge: barriers to knowing in the firm. Thousand Oaks, California: Sage Publications Inc., 2003.

TAAL, S.; VELDE, M. van der; LANGBROEK, P. Reducing Unwarranted Disparities: The Challenge Of Managing Knowledge Sharing Between Judges. International Journal For Court Administration, v. 6, n. 2, Dec. 2014.

TARAPANOFF, K. Informação, conhecimento e inteligência em corporações: relações e complementaridade. In: TARAPANOFF, K. (Org.). Informação, conhecimento e inteligência em corporações. Brasília: IBICT, UNESCO, 2006. p. 19-36.

TAYLOR, F. W. Princípios de administração científica. 8. ed. São Paulo: Atlas, 1990.

TEIXEIRA FILHO, J. Comunidades virtuais. Rio de Janeiro: Senac, 2002.

TEIXEIRA, E. As três metodologias: acadêmica, da ciência e da pesquisa. 9. ed. Petrópolis: Vozes, 2012.

TICKY, N. M. Controle seu destino antes que alguém o faça: como Jack Welch está transformando a General Eletric na empresa mais competitiva do mundo. São Paulo: Educator, 1993.

TOMAÉL, M. I.; ALCARÁ, A. R.; DI CHIARA, I. G. Das redes sociais à inovação. Ci. Inf., Brasília, v. 34, n. 2, p. 93-104, maio/ago. 2005. 
TONET, H. C.; PAZ, M. G. T. Um modelo para o compartilhamento de conhecimento no trabalho. RAC, v. 10, n. 2, p. 75-94, abr./jun. 2006.

TSAI, W. Knowledge transfer in intraorganizational networks: effects of network position and absorptive capacity on business unit innovation and performance. Academy of Management Journal, v. 44, n. 5, p. 996-1004, 2001.

TURATO, E. R. Tratado da metodologia da pesquisa clínico-quantitativa: construção teórico-epistemológica, discussão comparada e aplicação nas áreas de saúde e humanas. 4. ed. Petrópolis: Vozes, 2010.

UNISANTA. Citações. 2004. Disponível em:

<http://professores.unisanta.br/oleni/citacoes.htm>. Acesso em: abr. 2016.

VALENTIM, M. L. P. O processo de inteligência competitiva em organizações.

DataGramaZero, v.4, n.3, jun. 2003.

VAN CAENEGEM, W. Inter-firm migration of tacit knowledge: law and policy. Prometheus, v. 23, n. 3, set. 2005.

VAN DEN BRINK, P. Social, organizational, and technological conditions that enable knowledge sharing. 2003. Dissertação (Mestre)- Delft University of Technology, Netherlands, 2003.

VELLOSO, J. Mestres e doutores no país: destinos profissionais e políticas de pós-graduação. Cadernos de Pesquisa, v. 34, n. 123, p. 583-611, set./dez. 2004.

VICINI, L. Análise multivariada da teoria à prática. Santa Maria: UFSM, 2005.

VIEIRA, J. L. L. Um novo desafio para o Judiciário: o juiz líder. Porto Alegre: Tribunal de Justiça do Estado do Rio Grande do Sul, Departamento de Artes Gráficas, 2009.

VIEIRA, L. Fragmentos de um discurso ecológico: reflexões críticas de ecologia política. São Paulo em Perspectiva, v. 3, n. 4, p. 5-12, out./dez., 1989. Disponível em:

<http://www.seade.gov.br/produtos/spp/v03n04/v03n04 02.pdf >. Acesso em: 29 jun. 2013.

VON HIPPEL, E. The sources of innovation. New York : Oxford University Press, 1988.

WAH, L. Behind the buzz. Management Review, Apr. 1999.

WANG, C. B. Techno Vision II. São Paulo: Makron Books, 1998.

WERKEMA, C. Ferramentas estatísticas Básicas do Lean Seis Sigma Integradas ao PDCA e DMAIC. Rio de Janeiro: Elsevier, 2014.

WERSIG, G., NEVELING, U. The phenomena of interest to information science. The Information Scientist, v.9, n.4, 1975.

WHITE, D. M. The "Gate Keeper": A case study in the selection of news. In: BERKOWITZ, D. Social meanings of news: a text-reader. Thousand Oaks: Sage Publications, 1997.

WILBERT, J. K. W. et al. Comunidades de prática virtuais nos processos de inovação: aspectos e recomendações. CONGRESSO BRASILEIRO DE ENGENHARIA DE PRODUÇÃO, 5., 2015. Anais... Ponta Grossa: [s.n], 2015.

WILSON, T. D. The nonsense of 'knowledge management'. Information Research, v. 8, n. 1, Oct. 2002. 
WORKSHOP INTERNACIONAL EM CIÊNCIA DA INFORMAÇÃO (WICI), 8., 2012, Brasília. Anais... Brasília: Universidade de Brasília (UnB), 2012.

WORKSHOP BRASILEIRO DE INTELIGÊNCIA COMPETITIVA E GESTÃO DO

CONHECIMENTO, 10., 2012, Brasília. Anais... Brasília: IBICT, 2012

WORLD JUSTICE PROJECT.WJP Rule of Law Index 2015. Washington: WJP, 2015.

Disponível em: 〈http://worldjusticeproject.org/rule-of-law-index >. Acesso em: 08 jun. 2015.

YAKHLEF, A. Immobility of tacit knowledge and the displacement of the locus of

innovation. European journal of Innovation Management, v. 8, n. 2, p. 227-239, 2005.

ZACK, M. H. Knowledge and strategy. New York: Routledge, 2011.

ZAFFARONI, E. R. Poder Judiciário: crise, acertos e desacertos. São Paulo: Revista dos Tribunais, 1995. 


\section{APÊNDICE A - QUESTIONÁRIO APLICADO AOS JUÍZES DOS JEF}

\section{Apresentação}

\section{Termo de Consentimento livre e esclarecido}

Excelentíssimo(a) Senhor(a),

Sou Analista Judiciário do Tribunal Regional Federal da $1^{\text {a }}$ Região e aluno de Doutorado no Programa de Pós-Graduação em Ciência da Informação (PPGCINF) da Universidade de Brasília (UnB).

A fim de dar continuidade à investigação, consulto Vossa Excelência quanto à possibilidade de responder o questionário anexo cujo preenchimento deve despender cerca de oito minutos.

O questionário divide-se em três partes ou dimensões. Na primeira, serão solicitados dados pessoais, acadêmicos e funcionais. $\mathrm{Na}$ segunda, serão extraídos dados relativos às Varas, no âmbito organizacional e geopolítico. $\mathrm{Na}$ terceira, por fim, serão colhidas informações acerca da socialização do conhecimento tácito.

Sua participação é voluntária e a desistência poderá ocorrer a qualquer momento. Será assegurada a confidencialidade das respostas.

Ao final, haverá um campo para livre consideração acerca do que pode ser feito para acelerar e melhorar o trânsito de conhecimento tácito entre juízes dos Juizados Especiais Federais (JEFs).

Caso tenha interesse em conhecer os resultados desta pesquisa, por favor, assinale a opção abaixo:

Desejo conhecer os resultados da pesquisa.

Em situações de dúvida, contatos poderão ser realizados pelo telefone (61) 8152-0022 ou pelo email ferretti.ci@gmail.com

Desde já, agradeço a atenção.

Respeitosamente,

José Roberto Pimenta Ferretti

\section{Introdução ao contexto da pesquisa e questionário}

Minha pesquisa tem por tema o Conhecimento Tácito e por objeto o seu compartilhamento, segundo dimensões e variáveis que a alavancam e a obstruem.

O conhecimento tácito é um produto mental intangível, passível de compartilhamento e em constante reformulação. Composto por elementos abstratos (ideias, raciocínios, knowhow, habilidades, alegorias, modelos, constructos, insights, experiências, lembranças, sons, imagens, odor, gosto, tato, entre outros) é capaz de gerar novos conhecimentos e práticas inovadoras. 
O compartilhamento de conhecimento tácito representa um fenômeno descritível e mensurável de intercâmbio interpessoal. Representa uma interação quando fluxos de conhecimento tácito são estabelecidos entre pessoas. Pode ocorrer dentro das organizações ou entre estas, requer um ambiente de confiança social e propicia a incorporação de novos conteúdos com ganhos multilaterais de natureza agregadora.

\section{Dimensão Pessoal, Acadêmica e Funcional (PAF)}

1.1 - Nome (com o fim de possibilitar, se necessários, contatos futuros)

1.2 - Gênero<smiles>[Y14]C1CC2CCC12</smiles>

1.3 - Email

1.4 - Ano de nascimento

1.5 - Natural de (UF)

1.6 - Grau de formação

\begin{tabular}{l}
$\square$ Graduação \\
\hline$\square$ Pós-graduação \\
$\square$ Mestrado \\
$\square$ Doutorado \\
$\square$ Pós-doutorado
\end{tabular}

1.7 - Atua ou atuou como docente

$\square \operatorname{Sim}$

$\square$ Não

1.8 - Já publicou livros ou artigos

$\square \mathrm{Sim}$

Não

1.9 - Tempo de magistratura na JF

$\square$ menos de cinco anos

$\square$ entre cinco e dez anos

$\square$ entre 10 e 15

$\square$ mais de 15

1.10 - Sua hierarquia na Vara

$\square$ Titular

Substituto

1.11 - Há quanto tempo está como juiz de JEF?

$\square$ menos de um ano

$\square$ entre um e três anos

entre três e cinco

mais de cinco

\section{Dimensão Organizacional e Geopolítica (OG)}

2.1 - Vossa Excelência está lotada em

$\square$ Vara JEF
$\square$ Vara JEF Adjunto
$\square$ Turma Recursal


2.2 - Qual a competência de sua Vara

$\square$ Cível
$\square$ Criminal
$\square$ Cível e Criminal

2.3 - Quantas Varas JEF há em sua cidade:

2.4 - A qual Região da Justiça Federal pertence a sua Vara

$\square$ Primeira Região
$\square$ Segunda Região
$\square$ Terceira Região
$\square$ Quarta Região
$\square$ Quinta Região

2.5 - Em qual cidade está localizada a sua Vara (o sistema apresentará um menu de acordo com a Região escolhida no item anterior)

\begin{tabular}{|l}
$\square$ Cidade 1 \\
$\square$ Cidade 2 \\
$\square$ Cidade 3 \\
$\square$ etc
\end{tabular}

\section{Dimensão Social (S)}

3.1 - Como Vossa Excelência considera o grau de frequência de sua interação com outros juízes, no que diz respeito ao compartilhamento de ideias, experiências, expertise, habilidades, know-how, entendimentos jurídicos, modelos mentais e outros conteúdos mentais (conhecimento tácito).

$\square$ Muito grande
$\square$ Grande
$\square$ Mediano
$\square$ Pequeno
$\square$ Muito pequeno

3.2 - Em relação a sua interação com os operadores do Direito (advogados, procuradores, promotores, defensores), em que grau se dá a compartilhamento do conhecimento tácito

$\square$ Muito grande
$\square$ Grande
$\square$ Mediano
$\square$ Pequeno
$\square$ Muito pequeno

3.3 - Em relação a sua interação com os servidores de sua Vara, em que nível se dá o compartilhamento do conhecimento tácito

$\square$ Muito grande
$\square$ Grande
$\square$ Mediano
$\square$ Pequeno
$\square$ Muito pequeno

3.4 - Sua participação presencial em eventos de natureza interativa é

$\square$ Muito grande
$\square$ Grande
$\square$ Mediana
$\square$ Pequena




\section{$\square$ Muito pequena}

3.5 - Sua participação em eventos virtuais é

$\square$ Muito grande
$\square$ Grande
$\square$ Mediana
$\square$ Pequena
$\square$ Muito pequena

3.6 - Vossa Excelência participa de alguma rede social que trate de temas profissionais?

\section{Não}

$\square \operatorname{Sim}$

3.7 Caso tenha sido "sim" a resposta do item anterior, qual o número aproximado de membros?

$$
\begin{aligned}
& \square \text { até } 10 \text { membros } \\
& \square \text { entre } 10 \text { e } 50 \text { membros } \\
& \square \text { acima de } 50 \text { membros }
\end{aligned}
$$

3.8 - Vossa Excelência emprega alguma tecnologia de comunicação particular (smartphone, i-phones, tablets, i-pads, outros) para compartilhamento de conhecimento tácito (ideias, experiências, expertise, habilidades, entendimentos jurídicos, modelos e outros conteúdos mentais).

\section{Não}

$\square \operatorname{Sim}$

3.9 - Quando Vossa Excelência compartilha conhecimento tácito, este acontece mais frequentemente com (poderão ser assinalados até três cargos)

(Essa questão presta-se para estabelecer e conhecer vínculos intra-regionais, inter-regionais e nacionais de compartilhamento de conhecimento tácito, bem como verificar a existência de profissionais que atuam como elemento de multirelacionamento, ou seja, que mantém um alto grau de comunicação de conteúdo tácito com outras pessoas)

\begin{tabular}{|l|l|l|}
\hline$\square$ Juiz (a) Desembargador(a) & Cidade: & UF: \\
\hline$\square$ Juiz(a) Federal Titular & Cidade: & UF: \\
\hline$\square$ Juiz(a) Federal Substituto(a) & Cidade: & UF: \\
\hline Juiz(a) em Auxílio à Presidência & & \\
\hline $\begin{array}{l}\text { Juiz(a) em Auxílio à } \\
\text { Corregedoria dos Juizados }\end{array}$ & \\
\hline $\begin{array}{l}\text { Juiz(a) em Auxílio à } \\
\text { Coordenação doJEF) }\end{array}$ & \\
\hline \begin{tabular}{l} 
COJE \\
\hline
\end{tabular} & \\
\hline
\end{tabular}




\section{APÊNDICE B - TAMANHO DA AMOSTRA POR ESTRATO.}

\begin{tabular}{|c|c|c|c|c|c|}
\hline Regiao & Vara & Cargo & Tamanho População & $\begin{array}{l}\text { Proporção } \\
\text { População }\end{array}$ & Tamanho Amostra \\
\hline 1 & JEF & Substituto & 31 & $3,53 \%$ & 4 \\
\hline 1 & JEF & Titular & 56 & $6,37 \%$ & 6 \\
\hline 1 & JEF Adjunto & Substituto & 45 & $5,12 \%$ & 5 \\
\hline 1 & JEF Adjunto & Titular & 92 & $10,47 \%$ & 10 \\
\hline 1 & Turma Recursal & Substituto & 4 & $0,46 \%$ & 1 \\
\hline 1 & Turma Recursal & Titular & 45 & $5,12 \%$ & 5 \\
\hline 2 & JEF & Substituto & 24 & $2,73 \%$ & 3 \\
\hline 2 & JEF & Titular & 35 & $3,98 \%$ & 4 \\
\hline 2 & JEF Adjunto & Substituto & 21 & $2,39 \%$ & 3 \\
\hline 2 & JEF Adjunto & Titular & 20 & $2,28 \%$ & 3 \\
\hline 2 & Turma Recursal & Titular & 18 & $2,05 \%$ & 2 \\
\hline 3 & JEF & Substituto & 15 & $1,71 \%$ & 2 \\
\hline 3 & JEF & Titular & 43 & $4,89 \%$ & 5 \\
\hline 3 & JEF Adjunto & Substituto & 14 & $1,59 \%$ & 2 \\
\hline 3 & JEF Adjunto & Titular & 23 & $2,62 \%$ & 3 \\
\hline 3 & Turma Recursal & Substituto & 6 & $0,68 \%$ & 1 \\
\hline 3 & Turma Recursal & Titular & 36 & $4,10 \%$ & 4 \\
\hline 4 & JEF & Substituto & 37 & $4,21 \%$ & 4 \\
\hline 4 & JEF & Titular & 46 & $5,23 \%$ & 5 \\
\hline 4 & JEF Adjunto & Substituto & 40 & $4,55 \%$ & 5 \\
\hline 4 & JEF Adjunto & Titular & 45 & $5,12 \%$ & 5 \\
\hline 4 & Turma Recursal & Titular & 49 & $5,57 \%$ & 6 \\
\hline 5 & JEF & Substituto & 20 & $2,28 \%$ & 3 \\
\hline 5 & JEF & Titular & 22 & $2,50 \%$ & 3 \\
\hline 5 & JEF Adjunto & Substituto & 21 & $2,39 \%$ & 3 \\
\hline 5 & JEF Adjunto & Titular & 42 & $4,78 \%$ & 5 \\
\hline 5 & Turma Recursal & Titular & 29 & $3,30 \%$ & 4 \\
\hline \multicolumn{3}{|c|}{ Total } & 879 & $100,00 \%$ & 106 \\
\hline
\end{tabular}


APÊNDICE C - LISTA DOS JUÍZES SELECIONADOS NA AMOSTRA E AS

CIDADES ONDE ESTÃO LOCALIZADAS AS VARAS.

\begin{tabular}{|c|c|c|c|}
\hline Nome & Cargo & Vara & Região \\
\hline ...- Salvador (BA) & Titular & Turma Recursal & 1 \\
\hline ...- Rio Branco (AC) & Substituto & JEF & 1 \\
\hline ...- Oiapoque (AP) & Titular & JEF Adjunto & 1 \\
\hline ...- Salvador (BA) & Titular & JEF & 1 \\
\hline ...- Salvador (BA) & Titular & JEF & 1 \\
\hline$\ldots-$ Salvador (BA) & Titular & Turma Recursal & 1 \\
\hline ...- llhéus (BA) & Titular & JEF Adjunto & 1 \\
\hline$\ldots-$ Jequié $(\mathrm{BA})$ & Titular & JEF Adjunto & 1 \\
\hline ...-Brasília (DF) & Titular & JEF Adjunto & 1 \\
\hline ...- Goiânia (GO)- 10 & Titular & JEF & 1 \\
\hline ...- Cuiabá (MT) & Titular & Turma Recursal & 1 \\
\hline$\ldots-\operatorname{Sinop}(M T)$ & Titular & JEF Adjunto & 1 \\
\hline ...- Belo Horizonte (MG) & Titular & JEF & 1 \\
\hline ...- Belo Horizonte (MG) & Titular & JEF & 1 \\
\hline ...- Belo Horizonte (MG) & Titular & Turma Recursal & 1 \\
\hline ...- Belo Horizonte (MG) & Titular & Turma Recursal & 1 \\
\hline ...- Ipatinga (MG) & Titular & JEF Adjunto & 1 \\
\hline ...- Manhuaçu (MG) & Titular & JEF Adjunto & 1 \\
\hline ...-Viçosa (MG) & Titular & JEF Adjunto & 1 \\
\hline ...- Teresina (PI)- 20 & Titular & JEF & 1 \\
\hline$\ldots-\operatorname{Picos}(\mathrm{PI})$ & Titular & JEF Adjunto & 1 \\
\hline ...- Porto Velho (RO) & Titular & JEF Adjunto & 1 \\
\hline$\ldots$.. Salvador (BA) & Substituto & JEF Adjunto & 1 \\
\hline ...-Brasília (DF) & Substituto & JEF & 1 \\
\hline ...- Lusiânia (GO) & Substituto & JEF Adjunto & 1 \\
\hline ...- São Luis (MA) & Substituto & JEF Adjunto & 1 \\
\hline ...- Belo Horizonte (MG) & Substituto & JEF & 1 \\
\hline ...- Belo Horizonte (MG) & Substituto & JEF Adjunto & 1 \\
\hline ...- Belo Horizonte (MG) & Substituto & Turma Recursal & 1 \\
\hline ...- Sete Lagoas (MG)- 30 & Substituto & JEF Adjunto & 1 \\
\hline$\ldots$.. Palmas (TO) & Substituto & JEF & 1 \\
\hline ...- Rio de Janeiro & Substituto & JEF & 2 \\
\hline ...- Rio de Janeiro & Titular & JEF & 2 \\
\hline ...- Rio de Janeiro & Titular & Turma Recursal & 2 \\
\hline ...- Itaboraí (RJ) & Substituto & JEF Adjunto & 2 \\
\hline ...- Itaboraí (RJ) & Titular & JEF Adjunto & 2 \\
\hline ...- São Gonçalo (RJ) & Titular & JEF & 2 \\
\hline ...- Duque de Caxias (RJ) & Titular & JEF & 2 \\
\hline$\ldots-$ - Campos (RJ) & Titular & JEF & 2 \\
\hline ...- Macaé (RJ) - 40 & Titular & JEF Adjunto & 2 \\
\hline ...- Petrópolis (RJ) & Substituto & JEF Adjunto & 2 \\
\hline ...- Teresópolis (RJ) & Substituto & JEF Adjunto & 2 \\
\hline
\end{tabular}




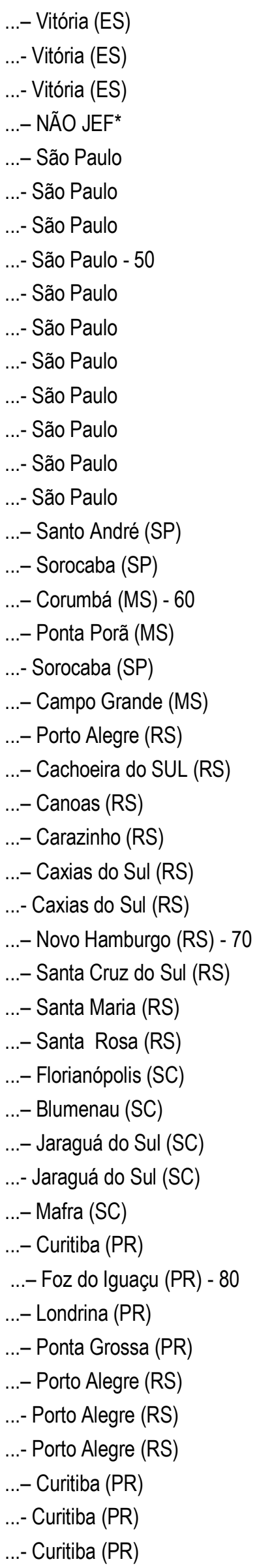

\begin{tabular}{|c|c|}
\hline Substituto & JEF \\
\hline Substituto & JEF \\
\hline Titular & Turma Recursal \\
\hline Titular & JEF Adjunto \\
\hline Substituto & JEF Adjunto \\
\hline Titular & JEF \\
\hline Titular & JEF \\
\hline Titular & JEF \\
\hline Titular & JEF \\
\hline Substituto & JEF \\
\hline Titular & Turma Recursal \\
\hline Titular & Turma Recursal \\
\hline Titular & Turma Recursal \\
\hline Titular & JEF Adjunto \\
\hline Substituto & JEF Adjunto \\
\hline Substituto & JEF \\
\hline Titular & JEF \\
\hline Titular & JEF Adjunto \\
\hline Titular & JEF Adjunto \\
\hline Substituto & Turma Recursal \\
\hline Titular & Turma Recursal \\
\hline Titular & JEF \\
\hline Substituto & JEF Adjunto \\
\hline Titular & JEF Adjunto \\
\hline Titular & JEF Adjunto \\
\hline Substituto & JEF \\
\hline Substituto & JEF Adjunto \\
\hline Substituto & JEF Adjunto \\
\hline Titular & JEF \\
\hline Substituto & JEF \\
\hline Substituto & JEF \\
\hline Substituto & JEF Adjunto \\
\hline Substituto & JEF Adjunto \\
\hline Titular & JEF \\
\hline Substituto & JEF \\
\hline Titular & JEF Adjunto \\
\hline Titular & JEF \\
\hline Titular & JEF Adjunto \\
\hline Titular & JEF Adjunto \\
\hline Titular & JEF \\
\hline Titular & Turma Recursal \\
\hline Titular & Turma Recursal \\
\hline Titular & Turma Recursal \\
\hline Titular & Turma Recursal \\
\hline Titular & Turma Recursal \\
\hline Titular & Turma Recursal \\
\hline
\end{tabular}


...- Crateús (CE)

...- Fortaleza (CE) - 90

\begin{tabular}{l|l|l} 
Substituto & JEF Adjunto & 5 \\
Titular & Turma Recursal & 5 \\
Titular & JEF & 5 \\
Titular & Turma Recursal & 5 \\
Titular & JEF Adjunto & 5 \\
Titular & JEF & 5 \\
Titular & JEF Adjunto & 5 \\
Substituto & JEF & 5 \\
Substituto & JEF & 5 \\
Titular & JEF & 5 \\
Titular & Turma Recursal & 5 \\
Titular & Turma Recursal & 5 \\
Substituto & JEF & 5 \\
Titular & JEF Adjunto & 5 \\
Titular & JEF Adjunto & 5 \\
Titular & JEF Adjunto & 5 \\
Substituto & JEF Adjunto & 5 \\
Substituto & JEF Adjunto & 5 \\
\hline
\end{tabular}

...-Aracaju (SE)

...-Recife (PE)

...- Jaboatão (PE)

...- Caruaru (PE)

...- Caicó (RN)

...- Caruaru (PE)

...- Natal (RN)

...- Fortaleza (CE)

...-Recife (PE)

...- Aracaju (SE) - 100

...-Recife (PE)

...- Fortaleza (CE)

...- Pau de Ferros (RN)

...- Sobral (CE)

...- Palmares (PE)

Substituto

...- Sousa (PB) - 106 5

* Um dos juízes informados não pertence ao JEF e por esta razão foi descartado. 


\section{APÊNDICE D - CARTA DA ORIENTADORA SOLICITANDO ENCAMINHAMENTO DO LINK-QUESTIONÁRIO AOS JUÍZES COM OS ELEMENTOS DA PESQUISA}

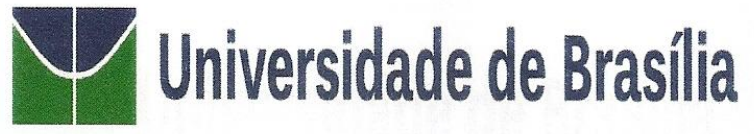

Faculdade de Ciência da Informação (FCl)

Programa de Pós-Graduação em Ciência da Informação - PPGCINF

Brasília, 01 de setembro de 2014

Ao

Excelentíssimo Senhor

Coordenador dos Juizados Especiais Federais da Primeira Região

Desembargador Federal REYNALDO SOARES DA FONSECA

Excelentíssimo Senhor Coordenador,

Conforme tratativas iniciais conduzidas com Vossa Excelência, participamos que se inicia a fase seguinte da pesquisa de doutorado.

O trabalho traz neste estágio a aplicação de questionários aos magistrados indicados na relação adenda, selecionados como amostra, a partir de informações transmitidas pela SecretáriaExecutiva da Coordenação dos Juizados (COJEF), Sandra Maria Alves Borges Costa, pela Supervisora da SEASS-ASMAG, Valéria Gonçalves Silva de Aquino, bem como, pela estagiária da COJEF, Michelly Ribeiro dos Santos. A todas agradecemos a sempre imediata e especial atenção.

Os dados recolhidos servirão para confirmar ou não a hipótese da pesquisa que prevê a existência de certos fatores que influenciam na mobilidade do conhecimento tácito e podem ser classificados em seis dimensões, pessoal, acadêmica, funcional, organizacional, geopolítica e social, conforme os elementos da pesquisa em anexo.

Os estágios seguintes abrigam a análise e interpretação das evidências obtidas, e a elaboração das conclusões.

$\mathrm{Na}$ certeza de que encontraremos em Vossa Excelência um incentivador dessa prova científica, solicitamos que os magistrados selecionados sejam convidados a participar, contribuindo com suas respostas por meio do link

https://pt.surveymonkey.com/s/ferretti pesquisa

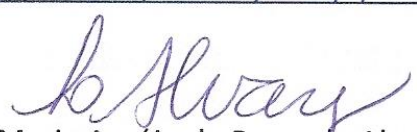

Prof $^{a} \mathrm{Dr}^{a}$ Lillian Maria Araújo de Rezende Alvares, Orientadora

Programa de Pós-Graduação em Ciência da Informação

Universidade de Brasília 


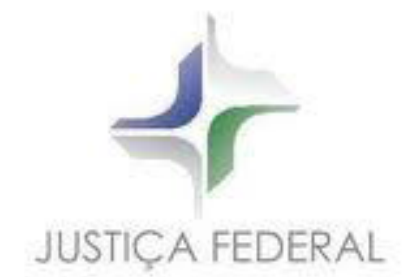

JUSTIÇA FEDERAL

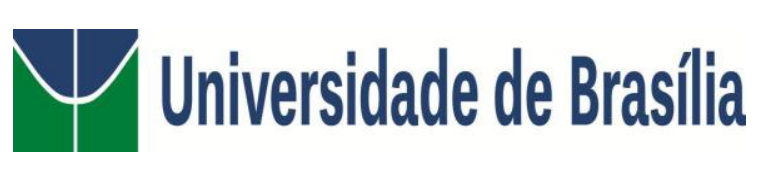

Faculdade de Ciência da Informação (FCI)

Programa de Pós-Graduação em Ciência da Informação - PPGCINF

ELEMENTOS DA PESQUISA DE DOUTORADO

\section{VARIÁVEIS DO COMPARTILHAMENTO DE CONHECIMENTO TÁCITO NOS JUIZADOS ESPECIAIS FEDERAIS DO BRASIL: IDENTIFICAÇÃO E MENSURAÇÃO}




\section{Problema}

Quais variáveis, na ótica dos juízes, explicam o compartilhamento do conhecimento tácito no âmbito dos Juizados Especiais Federais (JEF) do Brasil?

\section{Hipótese central}

O compartilhamento do conhecimento tácito, nos JEF, entre o juiz, os seus pares, os agentes externos e a sua equipe de trabalho varia de acordo com as dimensões pessoal, acadêmica, funcional, organizacional, geográfica e social.

\section{Objetivo geral}

Identificar as variáveis que explicam o compartilhamento do conhecimento tácito no âmbito dos Juizados Especiais Federais (JEF), consoante a perspectiva dos juízes.

\section{Objetivos específicos}

1) Analisar o processo de compartilhamento do conhecimento tácito segundo a literatura;

2) Mapear as possíveis variáveis associadas ao compartilhamento do conhecimento tácito entre os juízes do JEF;

3) Identificar as variáveis que explicam o fenômeno do compartilhamento do conhecimento tácito dentre as variáveis possíveis mapeadas.

\section{Conceitos do autor desenvolvidos com base na pesquisa}

Conhecimento tácito - é um produto mental intangível, passível de compartilhamento e em constante reformulação. Composto por elementos abstratos (ideias, raciocínios, know-how, habilidades, alegorias, modelos, constructos, insights, experiências, lembranças, sons, imagens, odor, gosto, tato, entre outros) é capaz de gerar novos conhecimentos e práticas inovadoras.

Compartilhamento de conhecimento tácito - é um fenômeno de intercâmbio interpessoal descritível e mensurável. Representa a interação de fluxos de conhecimento tácito estabelecida entre pessoas. Pode ocorrer dentro das organizações ou entre estas, requer um ambiente de confiança social e propicia a incorporação de novos conteúdos com ganhos multilaterais de natureza agregadora. 


\section{APÊNDICE E - QUESTIONÁRIO ADAPTADO ÀS VARIÁVEIS EXPLICATIVAS PARA CÁlCULO DO ICCT}

(aplicado em juízes fora da amostra para validação do e identificação de valor individual)

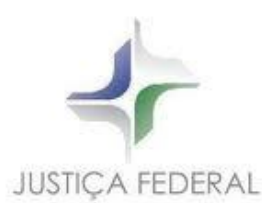

1. Dimensão Pessoal (P)

1.4 - Ano de nascimento

\begin{tabular}{|c|c|}
\hline J1 & Dados omitidos \\
\hline J2 & \\
\hline J3 & \\
\hline J4 & \\
\hline J5 & \\
\hline
\end{tabular}

2. Dimensão Funcional (F)

1.9 - Tempo de magistratura na JF

\begin{tabular}{|c|c|}
\hline J1 & Entre 10 e 15 anos \\
\hline J2 & Mais de 15 anos \\
\hline J3 & Mais de 15 anos \\
\hline J4 & Entre 10 e 15 anos \\
\hline J5 & Mais de 15 anos \\
\hline
\end{tabular}

$\square$ menos de cinco anos

$\square$ entre cinco e dez anos

$\square$ entre 10 e 15

$\square$ mais de 15

1.11 - Há quanto tempo está como juiz de JEF (Vara e Turma)? 


\begin{tabular}{|l|l|}
\hline J1 & Mais de 5 anos \\
\hline J2 & Mais de 5 anos \\
\hline J3 & Mais de 5 anos \\
\hline J4 & Mais de 5 anos \\
\hline J5 & Mais de 5 anos \\
\hline
\end{tabular}

$\square$ menos de um ano

$\square$ entre um e três anos

$\square$ entre três e cinco

$\square$ mais de cinco

\section{Dimensões Geográfica (G)}

2.3 - A qual Região da Justiça Federal pertence a sua Vara/TR

\begin{tabular}{|c|c|}
\hline $\mathrm{J} 1$ & $1^{\mathrm{a}}$ \\
\hline $\mathrm{J} 2$ & $1^{\mathrm{a}}$ \\
\hline $\mathrm{J} 3$ & $1^{\mathrm{a}}$ \\
\hline $\mathrm{J} 4$ & $1^{\mathrm{a}}$ \\
\hline $\mathrm{J} 5$ & $1^{\mathrm{a}}$ \\
\hline
\end{tabular}

\section{Dimensão Social (S)}

3.4 - Em qual grau de intensidade se dá a sua participação presencial em eventos de natureza interativa (em uma escala de 0 a 10)?

\begin{tabular}{|c|c|}
\hline J1 & 1 \\
\hline J2 & 5 \\
\hline J3 & 5 \\
\hline J4 & 8 \\
\hline J5 & 5 \\
\hline
\end{tabular}

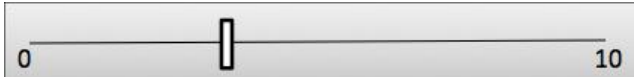

3.6 - Vossa Excelência participa de alguma rede social que trate de temas profissionais? 


\begin{tabular}{|c|c|}
\hline J1 & SIM \\
\hline J2 & NÃO \\
\hline J3 & SIM \\
\hline J4 & NÃO \\
\hline J5 & NÃO \\
\hline
\end{tabular}

3.7 - Vossa Excelência emprega alguma tecnologia de comunicação particular (smartphone, $i$ phones, tablets, i-pads, outros) para compartilhamento de conhecimento tácito (ideias, experiências, expertise, habilidades, entendimentos jurídicos, modelos e outros conteúdos mentais).

\begin{tabular}{|c|c|}
\hline J1 & SIM \\
\hline J2 & SIM \\
\hline J3 & SIM \\
\hline J4 & SIM \\
\hline J5 & Ñ̃O \\
\hline
\end{tabular}

4.2 - Vossa Excelência concorda que o compartilhamento do conhecimento tácito é imprescindível aos juízes para o melhor exercício de sua atividade judiciária (em uma escala de 0 a 10)?

\begin{tabular}{|c|c|}
\hline J1 & 10 \\
\hline J2 & 10 \\
\hline J3 & 4 \\
\hline J4 & 5 \\
\hline J5 & 5 \\
\hline
\end{tabular}

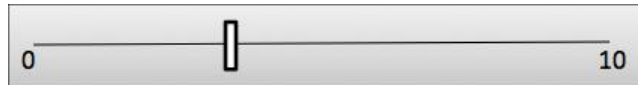




\section{ANEXO A - COMPETÊNCIA E ATRIBUIÇÕES DOS JUÍZES QUANDO NO EXERCÍCIO DAS FUNÇÕES DE DIRETOR DO FORO DAS SEÇÕES JUDICIÁRIAS E SUBSEÇÕES DA $4^{a}$ REGIÃO}

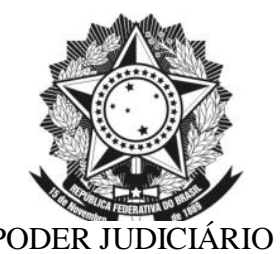

TRIBUNAL REGIONAL FEDERAL DA 4 a REGIÃO

PROVIMENTO N. ${ }^{\circ}$ 02, DE 16 DE JULHO DE 2004.

Dispõe sobre a competência e atribuições dos Juízes quando no exercício das funções de Diretor do Foro das Seções Judiciárias e Subseções da $4^{\mathrm{a}}$ Região e dá outras providências.

O PRESIDENTE DO TRIBUNAL REGIONAL FEDERAL DA $4^{\mathrm{a}}$ REGIÃO, no uso das atribuições que lhe confere o art. 16, inciso XIV, do Regimento Interno deste Tribunal, e tendo em vista o decidido no Processo Administrativo $\mathrm{n}^{\circ}$ 00.20.00088-0, em sessão do Conselho de Administração de 06/07/04, resolve:

Art. $1^{\circ}$ Cada Seção Judiciária terá um Juiz Federal Diretor do Foro, com as atribuições definidas neste Provimento.

Art. $2^{\circ}$ Cada cidade sede de Vara Federal constituir-se-á numa Subseção Judiciária e terá seu Diretor do Foro, com as atribuições adiante mencionadas.

Parágrafo único - Nas capitais dos Estados do Rio Grande do Sul, Santa Catarina e Paraná, o Diretor do Foro da Seção Judiciária será, também, o Diretor do Foro das Subseções de Porto Alegre, Florianópolis e Curitiba, respectivamente.

Art. $3^{\circ} \mathrm{O}$ Diretor do Foro da Seção Judiciária poderá delegar competência aos Diretores do Foro das Subseções para a prática de atos referentes aos servidores lotados nas Varas Federais do interior.

Art. $4^{\circ}$ Incumbe ao Diretor do Foro da Seção Judiciária:

I - Na área de recursos humanos:

a) dar posse aos servidores da Seção Judiciária;

b) lotar os servidores, observadas as disposições aprovadas pelo Tribunal Regional Federal da $4^{\mathrm{a}}$ Região;

c) proceder a alterações de lotação de servidores, no âmbito da sede da Seção Judiciária, observada a lotação ideal;

d) assinar as carteiras de identidade funcional dos servidores;

e) designar os titulares e substitutos das funções comissionadas e cargos em comissão, observada, quando for o caso, a necessidade de indicação, e ressalvada a competência do Tribunal;

f) determinar a elaboração das folhas de pagamento e autorizar o devido crédito;

g) decidir sobre as solicitações de consignação facultativa que lhes sejam submetidas pelo setor de pagamento de pessoal (art $45 \S$ único 8.112/90); 
h) conceder as indenizações de que trata o art. 51 e incisos, da Lei $n^{\circ}$ 8.112/90: ajuda de custo, diárias e indenização de transporte, observada a regulamentação em vigor;

i) conceder aos servidores as gratificações e os adicionais de que trata o art. 61 da lei $\mathrm{n}^{\circ}$ 8.112/90: retribuição pelo exercício de função de direção, chefia e assessoramento; gratificação natalina, adicional pela prestação de serviço extraordinário, adicional noturno, adicional de férias e outros adicionais relativos ao local e à natureza do trabalho;

j) conceder os benefícios de que tratam os artigos 185, 215 e 230 da Lei 8.112/90: auxílionatalidade, salário-família, licença para tratamento de saúde, licença à gestante, à adotante e licença-paternidade; auxílio-funeral, auxílio-reclusão, pensão (inclusive nas hipóteses de revisão e reversão de cotas) e assistência à saúde, bem como os benefícios de assistência pré-escolar, auxílio-alimentação e auxílio-transporte;

k) conceder férias, bem como autorizar a sua alteração e interrupção (art. 77 da Lei 8.112/90);

1) conceder aos servidores as licenças elencadas no art. 81 da Lei $n^{\circ} 8.112 / 90$ : por motivo de doença em pessoa da família, por motivo de afastamento do cônjuge ou companheiro, para o serviço militar, para atividade política, para capacitação, para tratar de interesses particulares e para desempenho de mandato classista; excetuadas as hipóteses de licenças por prazo superior a 90 (noventa) dias, ressalvada a licença para tratamento de saúde e a licença à gestante;

m)autorizar aos servidores as ausências ao serviço de que trata o art. 97 da Lei $\mathrm{n}^{\mathrm{o}}$ 8.112/90, em razão de: doação de sangue, alistamento como eleitor, casamento, falecimento do cônjuge, companheiro, pais, madrasta ou padrasto, filhos, enteados, menor sob guarda ou tutela e irmãos;

n) conceder horário especial ao servidor estudante, ao servidor portador de deficiência e ao que tenha cônjuge, filho ou dependente portador de deficiência física (art. 98 da Lei $8.112 / 90)$;

o) autorizar viagens de servidores da Seção Judiciária em objeto de serviço ou curso realizado no país;

p) autorizar afastamento de servidores da Seção Judiciária para freqüência a curso realizado no país, inclusive o curso de formação previsto no art. 20 , $\S 4^{\circ}$, da Lei $8.112 / 90$, por período inferior a 90 dias;

q) autorizar a averbação de tempo de serviço dos servidores para todos os fins legais (art. 100 da Lei 8.112/90);

r) homologar os resultados finais da avaliação de desempenho em estágio probatório dos servidores da Seção Judiciária;

s) elogiar e determinar o registro de elogios, férias, licenças, averbação de tempo de serviço, penalidades e demais atos relativos à vida funcional dos servidores lotados na Seção Judiciária;

t) instaurar sindicância e/ou processo administrativo disciplinar para apurar irregularidades ou infrações funcionais de servidores lotados na sede da Seção Judiciária, bem como irregularidades representadas pelos Diretores de Foro das Subseções Judiciárias, no caso de infração funcional que possa ser apenada com suspensão superior a 30 dias ou pena mais grave;

u) julgar sindicâncias e processos administrativos disciplinares, observado o disposto no art. 167 e parágrafos, da Lei $n^{\circ} 8.112 / 90$;

v) aplicar as penalidades previstas no art. 141, inciso II e III da Lei $\mathrm{n}^{\circ} 8.112 / 90$, a servidores lotados na Seção Judiciária;

w) encaminhar ao Presidente do Tribunal os processos administrativos disciplinares, passíveis de pena de demissão, cassação da aposentadoria ou da disponibilidade de servidor (art. 141, I, da Lei no 8.112/90);

x) comunicar ao Presidente do Tribunal a aplicação de penas disciplinares a servidores; 
y) conhecer e decidir pedidos de reconsideração dos seus atos e decisões, na forma do art. 106, parágrafo único, da Lei n ${ }^{\circ} 8.112 / 90$.

II - Na área de recursos humanos, nos processos de competência do Tribunal:

a) instruir e submeter ao Tribunal os casos de readaptação, reversão, reintegração, recondução, bem como disponibilidade e aproveitamento de servidores;

b) instruir e submeter ao Tribunal os pedidos de deslocamentos de servidores, de que tratam os artigos 36, 37, 93, 94 e 95 da Lei $n^{\circ}$ 8.112/90: remoção com mudança de sede, redistribuição, afastamento para servir a outro Órgão ou Entidade, afastamento para mandato eletivo e afastamento para estudo ou missão no exterior, bem como licenças e outros afastamentos por período superior a 90 dias, exceto nos casos de licença-gestante e licença-saúde;

c) instruir e encaminhar os processos de designação de Diretor de Secretaria de Vara, após indicação dos Juízes Federais, bem como do Diretor da Secretaria Administrativa, Assessor do Diretor do Foro e Diretor de Núcleo, observados os requisitos legais;

d) instruir e encaminhar ao Tribunal os pedidos de vacância do cargo, decorrentes de exoneração, aposentadoria, readaptação, posse em outro cargo inacumulável e falecimento;

e) instruir e submeter ao Tribunal os casos em que constatada a acumulação proibida de cargos públicos.

III - Na Administração de Obras, Compra de Bens e Serviços:

a) autorizar a abertura de processos de licitação;

b) ratificar a inexigibilidade ou a dispensa de licitação, observada a legislação pertinente;

c) decidir, em grau de recurso, as questões suscitadas nos processos licitatórios;

d) aplicar sanções administrativas aos contratados e licitantes;

e) homologar procedimento de licitação;

f) assinar contratos e convênios em nome da Seção Judiciária.

IV - Na Administração Orçamentária e Financeira:

a) reportar-se, na condição de Órgão integrante do Sistema de Orçamento e Finanças da Justiça Federal, diretamente ao Tribunal Regional Federal da 4a Região, no que concerne à obediência de normas e diretrizes básicas à Administração Orçamentária e Financeira;

b) autorizar a execução da despesa da Seção Judiciária - Unidade Seccional, relativamente aos créditos orçamentários descentralizados pelo Tribunal - Unidade Setorial;

c) acompanhar e coordenar a elaboração da Proposta Orçamentária Anual;

d) coordenar a execução orçamentário-financeira da despesa, e, quando necessário, submeter à apreciação do Tribunal medidas para promover os ajustes da Programação Orçamentária;

e) encaminhar as propostas de programação financeira nos prazos e em conformidade com as normas estabelecidas pela Unidade Setorial do Sistema, bem como manter registros e controles dos recursos financeiros recebidos.

V - Na administração geral:

a) despachar o expediente da Secretaria Administrativa;

b) expedir atos decorrentes das decisões de sua própria competência;

c) requisitar passagens e transporte, observando, quando necessário, a existência de autorização do Presidente do Tribunal ou Corregedor;

d) determinar o fechamento do Foro de acordo com as disposições legais e deliberações do Tribunal;

e) constituir e designar comissões de natureza temporária ou permanente, no âmbito de sua competência; 
f) designar servidor para cumprir horário de trabalho diverso do estabelecido no art. $1^{\circ}$ da Resolução n. ${ }^{\circ}$ 01, de 02-03-94, do Tribunal Regional Federal da 4a Região, observado o disposto no art. $2^{\circ}$ da mesma Resolução;

g) autorizar a prestação de serviços extraordinários pelos servidores da Seção Judiciária, de acordo com a legislação vigente e Resoluções do Tribunal e do Conselho da Justiça Federal;

h) atuar como ordenador de despesas;

i) gerenciar a cobrança das custas e os serviços de apoio administrativo e judiciário;

j) prestar contas ao órgão de Controle Interno, quando solicitado;

k) dispor sobre o local destinado à guarda dos veículos da sede da Seção Judiciária, serviços de portaria, conservação e segurança do Foro;

1) designar locais onde devam ser realizadas as arrematações e leilões judiciais;

m) firmar contratos e convênios no âmbito de sua competência;

VI- Na Central de Mandados:

a) proceder à regulamentação do funcionamento interno da Central de Mandados, definição das competências e atribuições das funções comissionadas que a compõem;

b) exercer a supervisão técnica da Central de Mandados, podendo delegar tal atividade a outro magistrado, cabendo-lhe, ainda, solucionar as dúvidas relativas aos seus serviços, observadas as normas gerais estabelecidas pela Corregedoria-Geral da Justiça Federal da $4^{a}$ Região.

VII - Na interação com o Tribunal Regional Federal:

a) encaminhar, anualmente, no mês de agosto, a necessidade de lotação de servidores e propor alterações no quadro Ideal por Vara ou unidades administrativas ouvidos os demais juízes;

b) submeter ao Corregedor-Geral as escalas de férias semestrais dos Juízes Federais e dos Juízes Federais Substitutos até o dia 10 de novembro para gozo nos meses de janeiro a junho, e até o dia 10 de maio para gozo nos meses de julho a dezembro;

c) elaborar, anualmente, o relatório consolidado das atividades da Seção Judiciária, encaminhando-o ao Presidente do Tribunal, até 05 de fevereiro;

d) submeter ao Tribunal proposta de alteração na organização e estruturação dos serviços administrativos da Seção Judiciária;

e) submeter a proposta orçamentária e solicitações de abertura de créditos adicionais, nas épocas e condições determinadas, fornecendo todos os elementos necessários para a análise do Tribunal;

f) sugerir ao Tribunal a criação, instalação ou especialização de Varas em determinadas matérias, ouvidos os demais Juízes.

Art. $5^{\circ}$ Compete ao Diretor do Foro da Subseção Judiciária:

a) dar posse aos servidores da Subseção, mediante delegação do Diretor do Foro da Seção Judiciária;

b) elogiar e encaminhar à Direção do Foro da Seção Judiciária os elogios feitos aos servidores lotados na Subseção Judiciária, para fins de anotação nos registros funcionais;

c) instaurar sindicâncias para apurar irregularidades ou infrações funcionais punidas com a pena de advertência ou suspensão de até 30 (trinta) dias, de acordo com o art. 141, Inciso III, da Lei n. ${ }^{\circ}$ 8.112/90;

d) aplicar pena disciplinar de advertência ou suspensão de até 30 (trinta) dias, comunicando ao Diretor do Foro da Seção Judiciária para fins de registro nos assentamentos funcionais dos servidores; 
e) comunicar ao Diretor do Foro da Seção Judiciária a ocorrência de faltas funcionais passíveis de pena de suspensão por mais de 30 (trinta) dias, demissão ou cassação de aposentadoria ou disponibilidade;

f) conhecer e decidir pedidos de reconsideração dos seus atos e decisões, na forma do art. 106, parágrafo único, da Lei n. ${ }^{\circ} 8.112 / 90$;

g) deliberar sobre os serviços de natureza administrativa da Subseção Judiciária, observadas as disposições sobre a matéria e os procedimentos adotados pela Direção do Foro da Seção Judiciária;

h) propor ao Tribunal a designação de local para instalação de Varas, salas destinadas ao Ministério Público ou à Ordem dos Advogados do Brasil e medidas análogas;

i) dispor sobre o local destinado à guarda dos veículos da Subseção Judiciária, serviços de portaria, conservação e segurança do Foro;

j) designar locais onde devam ser realizadas as arrematações e leilões judiciais;

k) exercer a fiscalização dos serviços administrativos da Subseção Judiciária;

1) proceder a alterações de lotação de servidores no âmbito da Subseção Judiciária;

Art. $6^{\circ}$ Compete ao Diretor do Foro da Seção ou da Subseção Judiciária, no âmbito respectivo dessas:

a) representar a Seção Judiciária ou Subseção perante os órgãos federais, estaduais, municipais, autoridades ou em solenidades;

b) firmar Convênios e Termos Aditivos com as instituições de ensino locais, de forma a possibilitar a implantação do estágio remunerado a estudantes universitários e de $2^{\circ}$ graus, no âmbito da sede das respectivas Subseções;

c) designar, mensalmente, em sistema de rodízio, os Juízes que exercerão as atividades do plantão e da distribuição, indicando um substituto para hipóteses de impedimento ocasional;

d) conceder aos servidores compensação por dias trabalhados em regime de plantão, bem como por serviços prestados à Justiça Eleitoral;

e) delegar competência a servidores investidos em funções de chefia, nos termos da legislação pertinente e regulamentações expedidas pelo Conselho da Justiça Federal e o Tribunal Regional Federal da $4^{\mathrm{a}}$ Região, para a prática de atos administrativos, conforme a área de atuação.

Art. $7^{\circ}$ Os Juízes Federais e os Juízes Federais Substitutos, ao se dirigirem ao Presidente do Tribunal ou ao Corregedor, deverão fazê-lo diretamente, e não através de ofício dirigido ao Diretor do Foro.

Art. $8^{\circ}$ Este Provimento revoga os Provimentos de números 13, de 04/04/94, 15, de 10/06/94, 20, de 26/01/95, 72, de 30/04/97, e 112, de 07/04/2000, da Presidência desta Corte, e demais disposições em contrário e entra em vigor na data de sua publicação.

\section{PUBLIQUE-SE. REGISTRE-SE. CUMPRA-SE.}

Desembargador Federal Vladimir Passos de Freitas

Presidente 


\section{ANEXO B - DOCUMENTO AUTORIZATIVO DE REALIZAÇÃO DA PESQUISA (TRF1)}

ENC: TRF1 - Pesquisa de doutorado - Coleta de dados e informações

COJEF-TRF1 Coordenação dos JEF $1^{\text {a }}$ Região

$15 / 09 / 14$

$<$ cojef.trf1@trf1.jus.br>

para $(\ldots)$

Senhores Juízes,

Esta Coordenação concordou em apoiar a pesquisa científica da Universidade de Brasília, cujos dados recolhidos visam verificar a eventual existência de fatores que influenciam a mobilidade do conhecimento tácito, bem como sua classificação dimensional, maiores informações constantes no e-mail abaixo e na documentação anexa.

Para tanto, solicito de todos os selecionados especial colaboração para o preenchimento do questionário acessado no link: $<$ https://pt.surveymonkey.com/s/ferretti_pesquisa $>$.

Atenciosamente,

Coordenador dos Juizados Especiais Federais da 1a Região

De: josé roberto pimenta ferretti da costa [mailto:ferretti.ci@gmail.com]

Enviada em: terça-feira, 9 de setembro de 2014 10:15

Para: COJEF-TRF1 Coordenação dos JEF 1a Região; josé roberto pimenta ferretti da costa

Assunto: TRF1 - Pesquisa de doutorado - Coleta de dados e informações

\section{Senhora Secretária-Executiva da Coordenação dos Juizados Especiais Federais da Primeira Região}

Sandra Maria Alves Borges Costa

Prezada Secretária-Executiva,

Conforme as tratativas em curso, inicia-se a fase em que se solicita aos magistrados o preenchimento do questionário que colherá os dados e as informações pertinentes à pesquisa em desenvolvimento, consoante os elementos do estudo que seguem anexados.

Em razão de a amostra ter sido procedida em junho do corrente, os dados dos juízes, como titularidade, cidade de origem e outros, referem-se a tal período.

Com o fim de formalizar este estágio, seguem adendas, a carta da $\operatorname{Prof}^{a} \operatorname{Dr}^{a}$ Lillian Maria Araújo de Rezende Alvares, Orientadora da Pesquisa, ao Coordenador dos Juizados, na qual solicita o encaminhamento do link abaixo aos juízes selecionados, bem como a relação dos magistrados (indicados pela amostra) que preencherão o questionário.

O link que permite o acesso ao questionário é:

https://pt.surveymonkey.com/s/ferretti_pesquisa

Certo de que se pode contribuir para avanços significativos em prol do melhor desempenho dos Juizados, contamos com sua sempre efetiva atenção.

Atenciosamente,

José Roberto Ferretti

Analista Judiciário - TRF1

Doutorando da UnB

61 8152-0022 


\section{ANEXO C - DOCUMENTO AUTORIZATIVO DE REALIZAÇÃO DA PESQUISA}

(TRF2)

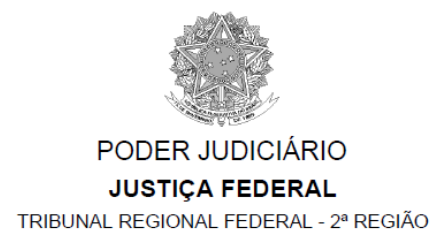

OFÍCIO No TRF2-OFI-2013/18924

Rio de Janeiro, 04 de setembro de 2013.

Prof $^{a}$ Dr $^{\text {a }}$ Lillian M. A. de Rezende Alvares

Coordenadora do Programa de Pór-Graduação em Ciência da Informação

Universidade de Brasília

Campus Universitário Darcy Ribeiro, Ed. Biblioteca Central

Entrada Leste, Asa Norte, Brasília - DF

CEP 70910-000

Assunto: Clipping coletânea de reportagens sobre o Poder Judiciário

Prezada Coordenadora,

Em atenção ao Ofício n ${ }^{\circ}$ OI FCI PPGCINF 012/2013, de 03 do corrente, informo que autorizo a pesquisa na forma como requerida.

Solicito, no entanto, visando assegurar a agilidade e presteza do trabalho a ser realizado, que as duas primeiras etapas (pesquisa inicial; e aplicação de questionário e realização de entrevistas) sejam precedidas de comunicação a esta Presidência, com antecedência mínima de 10 (dez) dias, como segue:

a) indicação de quantos e quais órgãos serão objeto da pesquisa (no âmbito do Tribunal o contato do magistrado se dá com os servidores do próprio Gabinete, das secretarias relacionadas ao Gabinete, e, em âmbito administrativo, entre os Desembargadores que exercem funções administrativas - ex. Presidente, Corregedor - e os servidores da respectiva lotação);

b) indicação dos dias e horários em que acontecerão as pesquisas (no Tribunal o expediente interno é de $11 \mathrm{~h}$ às $19 \mathrm{~h}$, e o atendimento ao público de $12 \mathrm{~h}$ às 17h); e desta Corte.

c) a relação dos alunos/pesquisadores que circularão nas dependências

Atenciosamente,

SERGIO SCHWAITZER

Presidente 


\title{
ANEXO E - DOCUMENTO AUTORIZATIVO DE REALIZAÇÃO DA PESQUISA (TRF4)
}

\author{
TRIBUNAL REGIONAL FEDERAL DA $4^{\mathrm{a}}$ REGIÃO \\ Rua Otávio Francisco Caruso da Rocha, 300 - Bairro Praia de Belas - CEP 90010-395 - Porto Alegre - RS - \\ www.trf4.jus.br \\ 4 andar, torre A

\section{OFÍCIO - 1459348 - DG/APLANG}

Porto Alegre, 05 de julho de 2013.

\author{
A Senhora \\ Prof $^{a} \operatorname{Dr}^{\mathrm{a}}$ LILLIAN ALVARES \\ Coordenadora do Programa de Pós-Graduação em Ciência da Informação \\ Universidade de Brasília \\ Brasília - DF
}

Senhora Coordenadora,

Em atenção ao Ofício PPGCINF 011/2013, de 24/06/2013, informo-lhe da autorização para que seja realizada, neste Tribunal, a pesquisa nos termos referidos.

Além disso, ao cumprimentá-la, ao doutorando e à instituição pela iniciativa do estudo, designo os servidores Luiz Izidoro Zorzo e José Carlos Bonato para o acompanhamento e os auxílios necessários.

Atenciosamente,

Documento assinado eletronicamente por Tadaaqui Hirose, Presidente, em 08/07/2013, às 17:46, conforme art. $1^{\circ}$, III, "b", da Lei 11.419/2006.

A autenticidade do documento pode ser conferida no site http://www.trf4.jus.br/trf4/processos/verifica.php informando o código verificador $\mathbf{1 4 5 9 3 4 8}$ e o código CRC 571EA988. 


\section{ANEXO F - DOCUMENTO AUTORIZATIVO DE REALIZAÇÃO DA PESQUISA}

\section{(TRF5)}

De: Roan Paulo Valença Wanderley

Enviada em: segunda-feira, 29 de setembro de 2014 15:07

Para: coojefj1trce; coojefj1trpe; coojefj2trce; coojefj2trpe; coojefjtral; coojefjtrpb; coojefjtrrn; coojefjtrse; coojefjval; coojefjvce; coojefjvpb; coojefjvpe; coojefjvrn; coojefjvse

Cc: coordenadoria.jef

Assunto: Questionário - Gestão de Conhecimento no Judiciário

Exmos. Srs. Juízes Federais de JEFs, boa tarde.

Conforme autorização concedida pelo Exmo. Sr. Coordenador Regional dos JEFs da $5^{\mathbf{a}}$ Região, Des. Federal LÁZARO GUIMARÃES, solicitamos a colaboração de VV. Exas. no preenchimento do questionário anexo, o qual subsidiará a tese de doutorado do servidor José Roberto Ferreti, da Justiça Federal da 1 a Região, cujo tema busca "investigar como se dá a mobilidade do conhecimento tácito no âmbito dos Juizados Especiais Federais (JEF) , considerando as dimensões pessoal, organizacional e social, referentes aos juízes."

Como a pesquisa visa o magistrado selecionado, esclarecemos que o mesmo deverá respondê-lo independente da vara indicada ser, ou não, a atual jurisdição do juiz sugerido.

As respostas deverão ser encaminhadas à esta CooJEF5, que repassará ao servidor interessado.

À disposição,

Roan P. Valença Wanderley

CooJEF 5a Região

ramal 9773 


\section{ANEXO G - PLANO DIRETOR E PRIMEIRAS AÇÕES DIRETRIZES (TJ-RJ)}

\begin{tabular}{|c|c|}
\hline \multirow[b]{3}{*}{$\begin{array}{c}\text { Implementação do Processo de Planejamento } \\
\text { Estratégico do PJ }\end{array}$} & AÇÕES \\
\hline & $\begin{array}{l}\text { Alinhamento das atividades com os } \\
\text { direcionadores estratégicos do PJ; }\end{array}$ \\
\hline & $\begin{array}{l}\text { Participação nos projetos desenvolvidos } \\
\text { pela DGDIN; }\end{array}$ \\
\hline \multirow{5}{*}{$\begin{array}{c}\text { Implementação da Nova Estrutura } \\
\text { Organizacional }\end{array}$} & $\begin{array}{l}\text { Elaboração de Protocolo de Cooperação } \\
\text { (EMERJ/ESAJ/DGCON). }\end{array}$ \\
\hline & Escolha dos gestores, \\
\hline & Revisão do Regimento de Atribuições; \\
\hline & Integração das equipes; \\
\hline & Capacitação dos gestores. \\
\hline \multirow{3}{*}{$\begin{array}{c}\text { Certificação ISO 9001:2000 de Unidades do } \\
\text { PJ }\end{array}$} & $\begin{array}{l}\text { Apoio às unidades submetidas à } \\
\text { certificação; }\end{array}$ \\
\hline & $\begin{array}{l}\text { Indicação de servidores para realizarem } \\
\text { os Cursos sobre as normas ISO e para } \\
\text { exercerem o papel de auditores internos; }\end{array}$ \\
\hline & $\begin{array}{l}\text { Remodelagem do processo de trabalho } \\
\text { "Registrar Acórdãos" ("piloto" } \\
\text { desenvolvido junto à Secretaria da } 18^{\mathrm{a}} \\
\text { Câmara Cível). }\end{array}$ \\
\hline \multirow{3}{*}{$\begin{array}{c}\text { Implementação do Sistema Normativo } \\
\text { Administrativo }\end{array}$} & $\begin{array}{l}\text { Participação nas iniciativas de revisão das } \\
\text { RAD Gerais; }\end{array}$ \\
\hline & Desenvolvimento de RAD operacionais; \\
\hline & $\begin{array}{l}\text { Planejamento e início de execução da } \\
\text { instalação do Arquivo Central. }\end{array}$ \\
\hline \multirow{5}{*}{$\begin{array}{l}\text { Divulgação do Conceito de Gestão do } \\
\text { Conhecimento }\end{array}$} & $\begin{array}{l}\text { Participação no Programa de } \\
\text { Integração Funcional ; }\end{array}$ \\
\hline & $\begin{array}{l}\text { Criação da página da DGCON no } \\
\text { portal corporativo; }\end{array}$ \\
\hline & $\begin{array}{l}\text { Apresentação em eventos institucionais } \\
\text { e organização de palestras; }\end{array}$ \\
\hline & $\begin{array}{l}\text { Publicação de entrevista no } \\
\text { Informativo TJERJ/EMERJ. }\end{array}$ \\
\hline & Confecção e distribuição de folders. \\
\hline \multirow{3}{*}{$\begin{array}{l}\text { Estruturação da Rede de Conhecimento do } \\
\text { PJERJ }\end{array}$} & $\begin{array}{l}\text { Desenvolvimento do Banco de } \\
\text { Conhecimento em matéria de pessoal - } \\
\text { Projeto "Enunciados Administrativos; }\end{array}$ \\
\hline & $\begin{array}{l}\text { Redefinição do portal corporativo do } \\
\text { Poder Judiciário; }\end{array}$ \\
\hline & $\begin{array}{l}\text { Definição das políticas de disseminação } \\
\text { das informações do Poder Judiciário. }\end{array}$ \\
\hline
\end{tabular}

\section{OBSERVAÇÕES/PERÍODO}

Internalização da importância da gestão estratégica para o PJ, seja pela busca contínua de aprimoramento dos serviços prestados ao jurisdicionado, seja pela sensibilização às discussões travadas no ambiente externo.

Preenchimento dos cargos até o nível de chefia de serviço.

Objetivou-se capacitar os gestores em temas específicos sobre gestão do conhecimento.

Total engajamento das unidades da DGCON que funcionam como sistema de apoio operacional.

Otimização do processo de trabalho com vistas a diminuir o tempo de permanência dos processos no TJ.

Os servidores da DGCON vêm participando ativamente das revisões das RAD Gerais do TJERJ.

A elaboração das RAD Operacionais está sendo precedida de análise destinada à racionalização dos processos de trabalho.

A equipe do Gabinete da DGCON ministrou diversas palestras sobre gestão do conhecimento, num total aproximado de $15 \mathrm{~h}$, com participação de mais de 1500 ouvintes.

Foram distribuídos mais de 800 folders sobre a DGCON.

Sobre essas ações é oferecido detalhamento nos subcapítulos que se seguem.

Com relação à redefinição do portal corporativo foi desenvolvido estudo preliminar pela DGTEC. 


\section{ANEXO H - VISITAS EXTERNA REALIZADAS PELO TJ-RJ COM O PROPÓSITO DE COMPARTILHAR CONHECIMENTOS}

\begin{tabular}{|c|c|c|}
\hline VISITAS & LOCAL/DATA & MOTIVO \\
\hline Petrobrás & $\mathrm{RJ}-28 / 01$ & $\begin{array}{c}\text { Conhecer o trabalho na área de Gestão do } \\
\text { Conhecimento desenvolvido pela } \\
\text { Empresa. }\end{array}$ \\
\hline Arquivo Nacional & $\mathrm{RJ}-17 / 05$ & Conhecer instalações e sistema informatizado. \\
\hline VISITAS & LOCAL/DATA & MOTIVO \\
\hline $\begin{array}{l}\text { 1-SupremoTribunal Federal } \\
\text { 2- Superior Tribunal de Justiça } \\
\text { 3- Tribunal de Justiça do } \\
\text { Distrito Federal } \\
\text { 4- Serviço Federal de } \\
\text { Processamento de Dados } \\
\text { (SERPRO) }\end{array}$ & $\begin{array}{c}\text { Brasília } \\
25 \text { e } 26 / 05\end{array}$ & $\begin{array}{c}\text { Colher dados e informações a respeito das } \\
\text { iniciativas de sucesso adotadas pelo Supremo } \\
\text { Tribunal Federal, pelo Superior Tribunal de } \\
\text { Justiça e pelo Tribunal de Justiça do Distrito } \\
\text { Federal, no que concerne à documentação, à } \\
\text { preservação e à disseminação da produção } \\
\text { jurisprudencial; } \\
\text { Identificar as ferramentas de tecnologia de } \\
\text { informação; } \\
\text { Conhecer a experiência do SERPRO na área de } \\
\text { Gestão do Conhecimento }\end{array}$ \\
\hline $\begin{array}{c}\text { Centro Cultural da Justiça } \\
\text { Federal }\end{array}$ & $\mathrm{RJ}-08 / 07$ & $\begin{array}{c}\text { Conhecer instalações e procedimentos de } \\
\text { trabalho. }\end{array}$ \\
\hline Imprensa Oficial do RJ & $\begin{array}{l}\text { RJ (Niterói) } \\
22 / 07\end{array}$ & $\begin{array}{c}\text { Conhecer instalações e procedimentos de } \\
\text { trabalho. }\end{array}$ \\
\hline $\begin{array}{l}\text { Centro de Documentação da } \\
\text { Rede Globo }\end{array}$ & RJ - 28/07 & $\begin{array}{c}\text { Apresentar aspectos essenciais do plano de } \\
\text { gestão de documentos e arquivos do TJERJ e } \\
\text { suas implicações na preservação da memória e } \\
\text { resgate da cidadania. }\end{array}$ \\
\hline Empresa QSI & RJ - 28/07 & $\begin{array}{l}\text { Pesquisa mercadológica para apoio operacional } \\
\text { ao DEGEA. }\end{array}$ \\
\hline $\begin{array}{l}\text { Fundação Nacional de Arte } \\
\text { (FUNARTE) }\end{array}$ & $\begin{array}{c}\text { Rio de Janeiro- } \\
05 / 08 / 2004 \\
\end{array}$ & $\begin{array}{l}\text { Conhecer instalações e procedimentos de } \\
\text { trabalho. }\end{array}$ \\
\hline $\begin{array}{l}\text { Bibliotecas da Academia } \\
\text { Brasileira de Letras, da } \\
\text { FIOCRUZ e do Centro Cultural } \\
\text { Banco do Brasil (CCBB) }\end{array}$ & RJ -Out-Nov/2004 & $\begin{array}{c}\text { Conhecer instalações e procedimentos de } \\
\text { trabalho. Benchmarking objetivando as futuras } \\
\text { instalações da Biblioteca do TJ }\end{array}$ \\
\hline $\begin{array}{c}\text { Centro de Pesquisa e } \\
\text { Documentação de História } \\
\text { Contemporânea do Brasil } \\
\text { (CPDOC) -FGV }\end{array}$ & RJ- 24/11 & $\begin{array}{l}\text { Conhecer procedimentos de trabalho referente à } \\
\text { digitalização e disponibilização de documentos. }\end{array}$ \\
\hline $\begin{array}{c}\text { Pontifícia Universidade Católica } \\
\text { do Rio de Janeiro (PUC) }\end{array}$ & RJ - 03/12 & $\begin{array}{c}\text { Apresentação de software sobre Gestão de } \\
\text { Competências }\end{array}$ \\
\hline
\end{tabular}




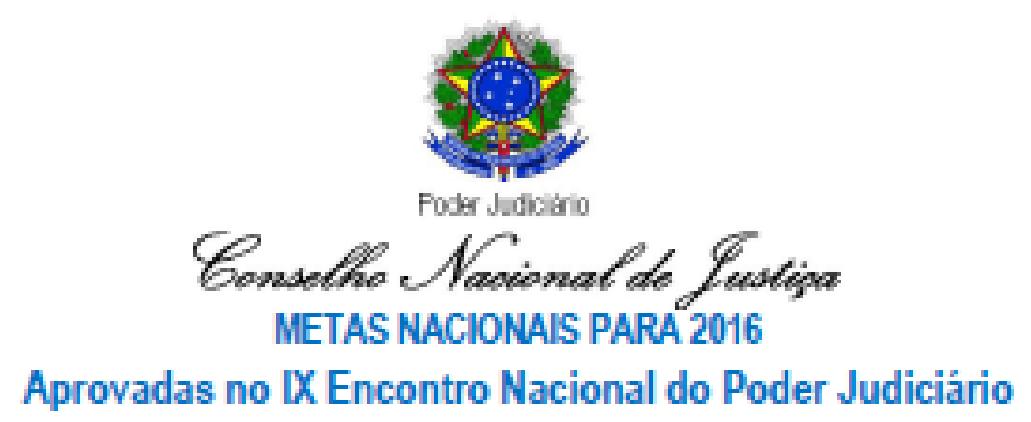

Os presidentes ou representartes dos tribunais do pois, reunidos em BrasilalDF, nos diss 24 e 25 de novembro de 2015 , durante o DX Enconbo Nacional do Poder Judiciärio, aproveram as Metas Nacionsis pare o Judiciario brasileino alcançar em 2016.

META 1 - Julgar mais processos que os distribuidos (Todos os segmentos)

Julgar quantidade maior de processos de conhecimento do que os distribuidos no ano comente.

META 2 - Julgar processos mais antigos (Todos os segmentos)

Identificar e julgar até 31/12/2016, pelo menos:

- No Superior Tribunal de Justiça, 99\% dos processos distribuidos aje 31/122011 e 90\% dos processos distribuidos em 2012;

- No Tribunal Superior do Trabalho, $100 \%$ dos processos distribuidos sie 31/12/2012, e pelo menos $90 \%$ dos processos distribuidos ate 31/12/2013;

- Na Justiça Miltar da Uniăo, $90 \%$ dos processos destribuidos ate 31/12/2014 nas Auj́bries Miltares, e 100\% dos processos detbuidos ate 31/12/2014 no STM;

- Na Justiça Federal, $100 \%$ dos processos distribuidos ste 31/12/2011 e 70\% dos processos distribuidos ste $31 / 12 / 2012$ no $10 \mathrm{e} 20$ grous, $100 \%$ dos processos distribuidos ste 31/12/2012 e $90 \%$ dos processos distribuidos ate 31/12/2013 nos Juizados Especiais Federsis, e 100\% dos processos deblibuibos ate 31/12/2012 e 70\% dos processos distribuidos abe 31/12/2013 nas Turmss Recursais;

- Na Justiça do Trabalho, $90 \%$ dos processos distrbuidos ate 31/12/2014, no $1^{12}$ e no 24 grous;

- Na Justiça Eleitoral, $90 \%$ dos processos diebrbuidos ate 31/12/2014;

- Nos Tribunais de Justiça Miltar Estaduais, 95\% dos processos desbibuidos ate 31/12/2014 nas Auditorias Militares, e $100 \%$ dos processos dathibuidos abe 31/12/2015, no $2^{4}$ grou; e

- Na Justipa Estadual, $80 \%$ dos processos distrbuidos sie $31 / 122012$ no 10 grou, $80 \%$ dos processos distribuidos ste 31/12/2013 no 24 grou, e $100 \%$ dos processos distribuidos sie 31/12/2013 nos Juizsdos Especisis e Tumas Recursais.

META 3 - Aumentar os casos solucionados por concilaç̧̃o (Justiça Federal e Justiça Estadual)

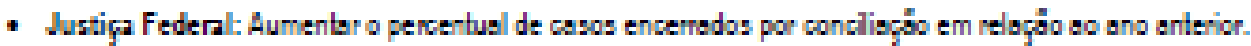

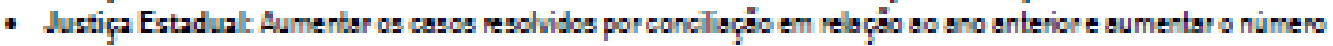
de CEJUSC:

- Justiça do Trabal ho: Aumentso o indice de Conclaç̧io na Fase de Conhecimento, em relaçäo à méda do bënio 20132014 , em 2 portos Pexcentuais. 


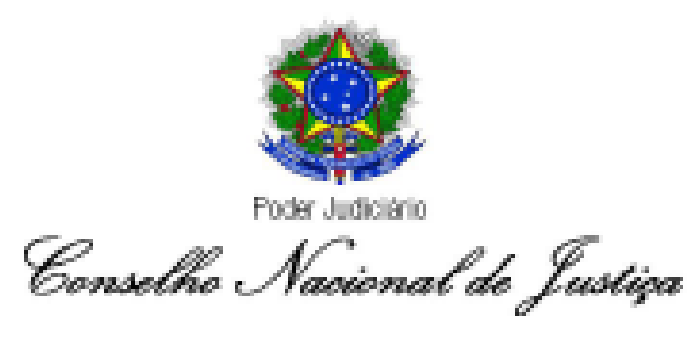

META 4- Priorizar o julgamento dos processos relativos à corrup̧̧ăo e à improbidade administrativa (STJ, Justiça Federal, Justiça Estadual e Justiça UTitar da Uniäo e dos Estadoa)

Identificar e julgar até 31/12/2016:

- Na Justiça Estadual, $70 \%$ das açöes de improbidade odministrafva e das açöes pensis relacionadas a crimes conba a sdministraçäo püblica distribuidss abe 31/12/2013;

- Na Justiça Federal, $70 \%$ das açöes de improbidsde sdministrativa dabibuidas ate 31/12/2014;

- Na Justiça Militar da Uniäo e dos Estados, as sçöes pensis relacionsdes a crimes contra a Administreçäo Püblice distrituidss aie 31/122014; $\mathrm{e}$

- No Superior Tribunal de Justiģa, $90 \%$ des sçōes de improbidade administrativa e des sp̧oses penais relacionsdas a crimes contre a Adminisbrȩ̣so Püblica distribuidas ate 31/12/2013 e 70\% das ạ̧es distribuidas em 2014

META 5 - Impulsionar processos à execuçăo (Justiça do Trabalho, Justip̧a Federal e Justiça Estadual)

Baixar em 2016:

- Na Justiça Federal, quantidede meior de processos de exscuçio näo facal do que o batal de casos novos de execuçio nío fiscal no sno comente;

- Na Justiça do Traba ho, quantidede maior de processos de exscuçäo do que o botal de casos novos de erecuçäo do ano corrents; $e$

- Na Justiça Estadual, idenfficar o número e a sihuaçăo dos processos de erecuçăo aie 31/12/2016.

META 6 - Priorizar o julgamento das ap̧óes coletivas (STJ, Justiça Estadual, Justiça Federal e Justiça do Trabalho Identificar e julgar até 31/12/2016:

- No STJ, $60 \%$ dos recursos oriundos de ap̧óes colefves distribuidas a pertir de 01/01/2015;

- Na Justiga Estadual, $60 \%$ das açöes colefves distribuidas ate 31/12/2013 no 10 greu, e $80 \%$ das açöes coletivas distribuidss aie $31 / 12 / 2014$ no $20 \mathrm{grsu}$;

- Na Justiça Federal, $100 \%$ das açóes colefves distribuidas ate $31 / 12 / 2012$ no $1{ }^{\circ}$ e 20 graus;

- Nos Tribunais Regionais e Juízes do Trabalho, as açóes coletivas destibuides ate $31 / 12 / 2013$ no 10 grsu e abe 31/12/2014 no 2* grou; e

- No Tribunal Superior do Traba ho, as açōes coletvas dabibuides ate 31/12/2013. 


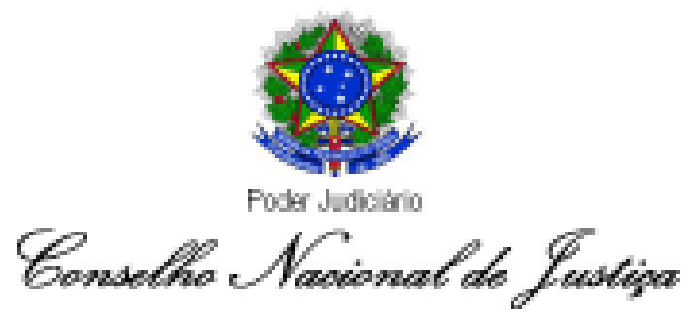

META 7 - Priocizar o julgamento dos processos dos maiores litigantes e dos recursos repetitivos (STJ, Justiça do Trabalho e Justiga Estadual)

- No Superior Tribunal de Justiga:

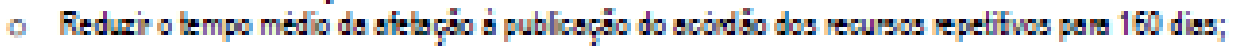

- Priorizs o julgsmento dos processos dos maiores lifiganies e dos recursos repeltivos; 5

- Julgar $40 \%$ do esioque de temes afetados ate 31/12/2014

- No Tribunal Superior do Trabalho, identficar e reduzir em $2 \%$ o aceno dos dez maiores litigantes em reloçbio so ano anterion.

- Nos Tribunais Regionais e Júzes do Trabalho, identficar e veduzir em $2 \%$ aceno dos dez maiores lifigantes em relsçäo 80 sno anterior.

- Nos Tribunais de Justiģa Estaduais, geri estrebegicamente as açoses de masso com identficaçäo e moniboremento do acenvo de demendss repestives.

META 8 - Implementar práticas de Justiça Restaurativa

- Justiça Estadual: Implementar projeto com equipe capocitedo pare cferecer próticas de Justiça Restourstivo, implantando ou qualficando pelo menos uma unidsde pars esse fm, ate 31.12.2016. 